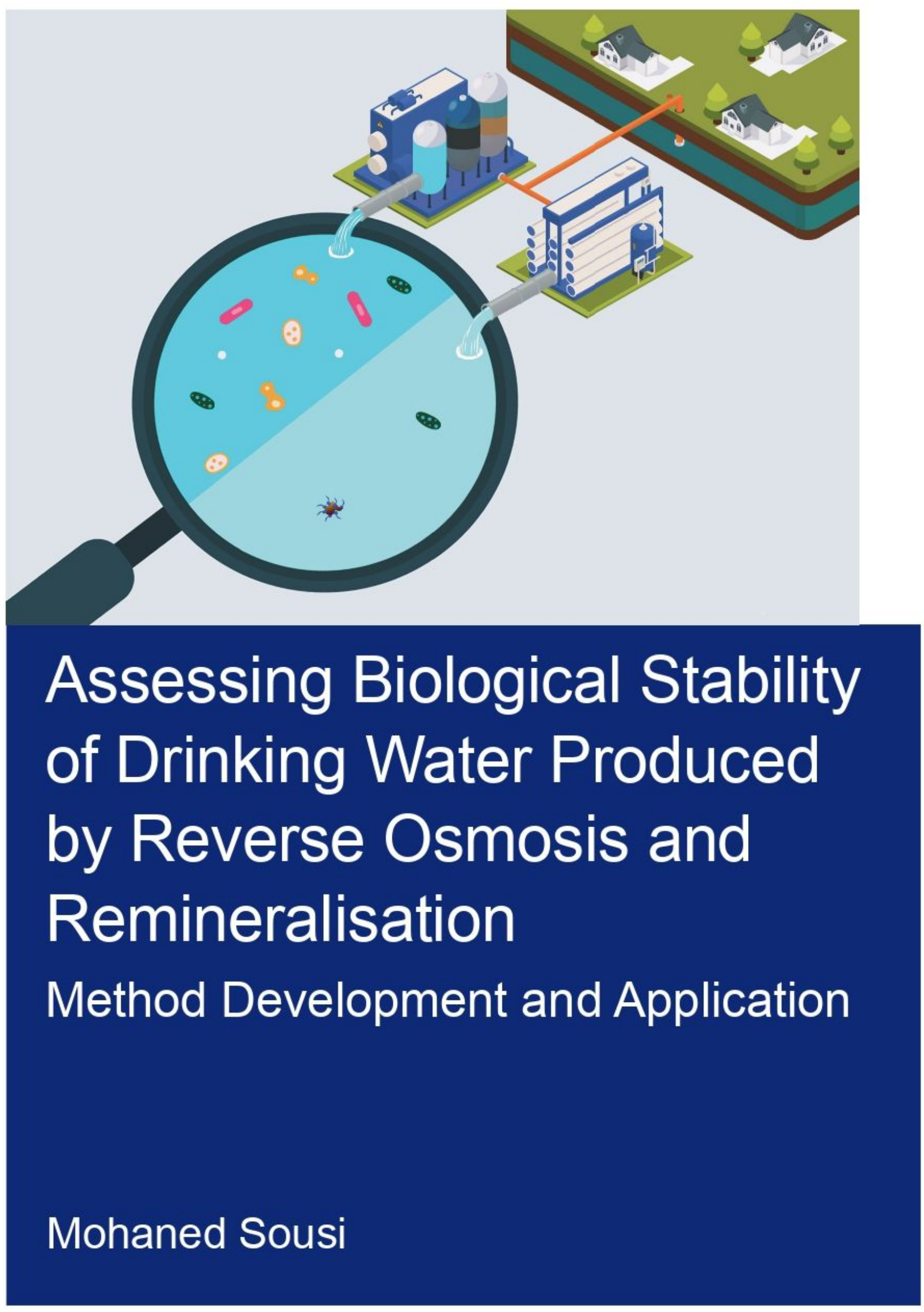




\section{ASSESSING BIOLOGICAL STABILITY OF DRINKING WATER PRODUCED BY REVERSE OSMOSIS AND REMINERALISATION \\ METHOD DEVELOPMENT AND APPLICATION}

Mohaned Sousi 



\title{
ASSESSING BIOLOGICAL STABILITY OF DRINKING WATER PRODUCED BY REVERSE OSMOSIS AND REMINERALISATION

\author{
METHOD DEVELOPMENT AND APPLICATION
}

\author{
DISSERTATION
}

to obtain

the degree of doctor at the Universiteit Twente, on the authority of the rector magnificus, prof. dr. ir. A. Veldkamp, on account of the decision of the Doctorate Board to be publicly defended on Thursday 9 December 2021 at 14.45 hours

\section{Mohaned Sameh Mahmoud Sousi}

born on the 30th of August, 1987

in Gaza, Palestine. 
This dissertation has been approved by:

Supervisors:

Prof. dr. ir. W.G.J. van der Meer

Prof. dr. ir. M.D. Kennedy

Co-supervisor:

Dr. ir. S.G. Salinas Rodríguez

This research was conducted under the auspices of the Graduate School for Socio-Economic and Natural Sciences of the Environment (SENSE).

Cover design: Faten Aljirjawi behance

Printed by: Veenman, the Netherlands

ISBN: 978-90-365-5301-8

DOI: $10.3990 / 1.9789036553018$

(C) 2021 Mohaned Sousi, The Netherlands. All rights reserved. No parts of this thesis may be reproduced, stored in a retrieval system or transmitted in any form or by any means without permission of the author. Alle rechten voorbehouden. Niets uit deze uitgave mag worden vermenigvuldigd, in enige vorm of op enige wijze, zonder voorafgaande schriftelijke toestemming van de auteur. 


\section{Graduation Committee:}

Chair / secretary:

Prof. dr. J.L. Herek

Supervisors:

Prof. dr. ir. W.G.J. van der Meer

Prof. dr. ir. M.D. Kennedy

Co-supervisor:

Dr. ir. S.G. Salinas Rodríguez

Committee Members:

Prof. dr. ir. H.D.W. Roesink

Prof. dr. ir. C.G.P.H. Schroën

Prof. dr. ir. H.H.M. Rijnaarts

Dr. ir. E.I.E.D. Prest

Prof. dr. ir. A.R.D. Verliefde
(University of Twente)

(University of Twente)

(Delft University of Technology/ IHE-Delft)

(IHE-Delft)

(University of Twente)

(University of Twente)

(Wageningen University \& Research)

(PWN-Technologies)

(Ghent University) 



\section{SUMMARY}

\section{Biological stability definition and controlling factors}

Water utilities aim at providing drinking water that remains biologically safe and stable during distribution. The term biological stability refers to maintaining the microbiological quality of drinking water without extensive bacterial growth, either quantitative or qualitative, during distribution. Growth of planktonic bacteria or biofilms in water distribution networks leads to several problems, such as health threats posed by (opportunistic) pathogens, operational problems including bio-corrosion of pipes and fittings, and adverse effects on the aesthetic characteristics of drinking water (i.e., taste, colour, and odour). Therefore, controlling bacterial growth in distribution systems is an important factor in complying with biological stability requirements, which can be achieved by the addition of residual disinfectant. However, drinking water in the Netherlands is distributed without residual disinfectant because of the health threats associated with the formation of disinfection by-products. Alternatively, multi-barrier treatment strategies are applied in the Netherlands to remove bacterial growth-promoting nutrients from source water.

Membrane technology, including reverse osmosis (RO) filtration, is increasingly applied worldwide in water purification processes, providing an effective solution for retaining substances that promote bacterial growth. Water after RO filtration (i.e., RO permeate) lacks the essential minerals for human consumption (e.g., calcium and magnesium). Therefore, post-treatment including remineralisation of RO permeate is required before distribution. However, limited knowledge is available on the effect of post-treatment (remineralisation) on the biological stability of ultra-low nutrient drinking water produced by RO filtration.

This study was conducted at a drinking water production site in the Netherlands where anaerobic groundwater is currently treated by conventional means comprising dry sand filtration (rapid sand filters fed with spray aerated water), pellet softening, rapid sand filtration, activated carbon filtration, and UV disinfection. At the same site, anaerobic groundwater is also treated by a pilot-scale unit comprising reverse osmosis and posttreatment (including remineralisation and aeration). Water samples were collected from both conventional and RO-based treatment line and assessed for biological stability using the bacterial growth potential (BGP) method.

\section{Method development}

The main aim of this dissertation was to further develop the current BGP method, using flow cytometry (FCM), for the assessment of biological stability of ultra-low nutrient water produced by RO and remineralisation. The results showed that cell count by FCM is reproducible for this type of water where changes in cell count and fluorescence fingerprints could be detected after on-site treatment or adjustments at the laboratory (Chapter 2, 3, and 
4). Furthermore, the limit of detection of the BGP method could be lowered by using ultrapure blank prepared from RO permeate that is remineralised at the laboratory. The lower limit of detection ensures obtaining reliable BGP results for water with very low BGP such as remineralised RO permeate (Chapter 2). The effect of sample pre-treatment prior to BGP measurement was assessed, where pre-treatment by pasteurisation or membrane filtration are commonly applied. It was found that membrane filtration has a pronounced negative influence on BGP of ultra-low nutrient water due to the leaching of organic filter material in water, whereas no significant effect of pasteurisation on the nutrient content of water was observed (Chapter 3).

Pre-treated water samples were inoculated using a natural bacterial consortium originating from conventionally treated drinking water, which was accompanied with the addition of nutrients to ultra-low nutrient water when a high inoculum concentration was added (Chapter 2). Alternatively, using bacteria originating from water produced by RO and remineralisation as an inoculum was evaluated, where it was observed that these bacteria have limited ability to utilise some types of organic compounds, more specifically organic carbon with complex molecular properties (Chapter 3). Therefore, an inoculum concentration of $10 \times 10^{3}$ intact cells $/ \mathrm{mL}$ originating from conventionally treated drinking water was considered throughout this research since the associated nutrient addition was found to be insignificant (Chapter 2). The developed BGP method was useful for the identification of bacterial growth-limiting nutrient in ultra-low nutrient water (Chapter 4). Moreover, the developed BGP method was combined with nutrient analysis, adenosine triphosphate (ATP) measurement, and 16S rRNA gene sequencing to obtain in-depth understanding of why growth occurs (limiting nutrients) and which bacteria grow (dominant bacterial genera) in the types of water studied (Chapter 4 and 5).

\section{Method application}

The application of the developed BGP method showed that the type of water treatment plays an important role in determining the biological stability of drinking water, where long term monitoring of BGP revealed that RO-based treatment ( $\mathrm{RO}$ and remineralisation) resulted in $>75 \%$ reduction in BGP compared with conventional treatment (Chapter 3), due to the high removal of organic and inorganic nutrients achieved by RO filtration ( $>99 \%$ removal). Moreover, it was observed that the BGP of RO permeate was negatively influenced by posttreatment, where the BGP increased by $100 \%$ when RO permeate underwent post-treatment processes at the production site. Post-treatment, especially remineralisation by calcite contactors, led to the addition of organic and inorganic nutrients in RO permeate (Chapter 4). For both water types, i.e., conventional drinking water and ultra-low nutrient water, organic carbon was the bacterial growth-limiting nutrient, even at very low concentrations of phosphate $(<1 \mu \mathrm{g} / \mathrm{L} \mathrm{PO} 4-\mathrm{P})$ (Chapter 4). The type of water treatment also shaped the bacterial community of the finished treated water, where the bacterial genera identified in RO-treated water were mainly introduced during the post-treatment processes (Chapter 4). Furthermore, it was found that the assessment of BGP using both FCM and ATP is especially useful as additional complementary information can be obtained from the 
combined tests, such as the effect of phosphate limitation on bacterial growth, where cellyield from phosphate was estimated at $0.70 \pm 0.05 \times 10^{9}$ cells $/ \mu \mathrm{g} \mathrm{PO}_{4} \mathrm{P}$ (Chapter 5).

\section{Outlook}

This study clearly demonstrated that RO filtration is a promising technology to considerably limit bacterial growth in drinking water. However, measures are recommended to mitigate the negative influences of post-treatment on BGP, such as using high quality calcite grains for remineralisation to prevent the introduction of organic and inorganic nutrients, and more frequent maintenance of the aeration towers, or even investigating alternative aeration methodologies (e.g., membrane aeration). Further research is needed to investigate the effect of RO-treated water on bacterial growth and ecology in the current distribution system, with a special focus on the transition period when switching from the current conventionally treated drinking water to RO-treated water. In the future, research should also focus on improving analytical techniques to elucidate the specific organic compounds that promote growth in drinking water as well as ensuring that these specific compounds are adequately removed during treatment. 


\section{SAMENVATTING}

\section{Biologische stabiliteit definitie en beïnvloedingsfactoren}

Drinkwaterbedrijven richten zich op het voorzien van biologisch veilig en stabiel drinkwater tijdens de distributie en tot aan het punt van consumptie. De term biologische stabiliteit impliceert aanhouden van dezelfde kwaliteit van drinkwater tijdens de distributie zonder grote veranderingen in hoeveelheid en kwaliteit op het gebied van microbiologische kwaliteit. Groei van planktonische bacteriën of biofilm in water distributie netwerken leidt tot ernstige problemen. Die brengt gevaren voor de gezondheid van consumenten doormiddel van ziekteverwekkers en daarnaast ook onderhoudsproblemen zoals biologische corrosie van de leidingen, en negatieve effecten op kleur, geur en smaak van het drinkwater. Het controleren van bacteriegroei is daarom een belangrijk component om te kunnen voldoen aan de biologische stabiliteit. Deze kan worden bereikt door het toevoegen van desinfecterend middelen aan water vóór distributie. In Nederland wordt drinkwater voorzien zonder toevoeging van een desinfecterend middel in verband met de daaraan gelinkte gezondheidsrisico's van deze middelen. Als alternatief is er in Nederland intensieve waterbehandeling geïmplementeerd om nutriënten te verwijderen uit het water zodat bacteriegroei wordt beperkt. Membraan technologie, inclusief omgekeerde osmose (RO) technologie, wordt wereldwijd steeds meer toegepast in drinkwaterprocessen. Deze technologieën voorzien een effectieve oplossing voor nutriënten verwijdering waardoor bacteriegroei wordt gelimiteerd. RO technologie produceert water met een zeer-lage concentratie aan nutriënten. Er is echter beperkte kennis op het gebied van de bepaling van biologische stabiliteit van water met een zeer-lage concentratie aan nutriënten. Bovendien is er weinig bekend over het effect van nabehandeling op RO permeaat.

Deze studie heeft plaatsgevonden op een drinkwatervoorziening locatie in Nederland waar op dit moment drinkwater wordt gewonnen uit zuurstofloos grondwater door middel van conventionele technieken bestaande uit droogzandfiltratie (snelle zandfilters gevoed met sproei-beluchte water), pelletverzachting, snelle zandfiltratie, actiefkoolfiltratie en UVdesinfectie. Op dezelfde locatie is ook een pilot installatie aanwezig die gebaseerd is op RO technologie en nabehandeling (inclusief remineralisatie en conditionering door middel van beluchting). Er worden tijdens dit onderzoek water monsters genomen van beide behandeling lijnen, (conventionele en RO-gebaseerde).

\section{Methode ontwikkeling}

Het doel van deze studie was om de methode voor bacteriegroei potentie (BGP) verder te ontwikkelen door middel van flow cytometry (FCM) zodat biologische stabiliteit van zeerlage nutriënten RO permeaat kan worden bepaald. De ontwikkeling van de BGP methode laten zien dat FCM reproduceerbaar is voor dit type water, waarbij veranderingen in bacteriële celtelling en bacterie eigenschappen kunnen worden gedetecteerd (Hoofdstuk 2, 3 en 4). Daarnaast is de detectie limiet van de BGP methode verlaagd door het gebruik van 
ultra-puur RO water waaraan mineralen zijn toegevoegd in het laboratorium voor de aanpassing van de chemische kwaliteit. Deze lage detectie limiet is nodig om betrouwbare resultaten te krijgen voor water met een zeer-lage concentratie aan nutriënten (Hoofdstuk 2 ). Bovendien is er gekeken naar het effect van sample voorbereiding (pasteurisatie en membraan filtratie) voordat de BGP meting plaatsvindt. Membraan filtratie heeft een negatief effect op BGP van water met een zeer-lage concentratie aan nutriënten doordat organische componenten van het membraan oplossen. Pasteurisatie heeft geen significant effect op de nutriënten concentratie in het water (Hoofdstuk 3).

Voorbehandelde water monsters zijn geënt met bacteriën die voorkomen in conventionele drinkwatervoorzieningen (zogenoemd inoculum). Door het enten van deze bacteriën worden er ook extra nutriënten toegevoegd aan het zeer-lage nutriënten water vooral bij hoge concentratie inoculum (Hoofdstuk 2). Een alternatief inoculum komend van water na RO en remineralisatie was geëvalueerd. Hierbij is geobserveerd dat deze bacteriën een limitatie hebben om sommige organische componenten te consumeren, vooral complexe organische stoffen (Hoofdstuk 3). Om deze reden is een inoculum concentratie van $10 \times 10^{3}$ intacte cellen/mL komende van conventionele drinkwatervoorzieningen gekozen voor dit onderzoek omdat de extra nutriënten toevoeging insignificant is (Hoofdstuk 2). De hiervoor genoemde BGP methode was bruikbaar voor de identificatie van groei-beperkende nutriënten voor de bacteriën in het water (Hoofdstuk 4). Bovendien was de ontwikkelde BGP methode gecombineerd met nutriënten analyses, adenosinetrifosfaat (ATP) meting en 16S RNA gen analyse om kennis op te doen over waarom groei plaatsvindt (beperkende nutriënten) en wie groeit (dominante bacteriële gen) in de verschillende types water (Hoofdstuk 4).

\section{Methode toepassing}

De toepassing van de ontwikkelende BGP methode in drinkwater productievoorzieningen in Nederland laat zien dat het type waterzuivering een belangrijke rol speelt in het bepalen van de biologische stabiliteit van het drinkwater. Lange termijn monitoren laat zien dat water behandeling gebaseerd op RO en remineralisatie leidt tot $>75 \%$ reductie in BGP in verhouding met een normale drinkwatervoorziening (Hoofdstuk 3). Deze substantiële reductie kan worden toegeschreven aan de significante verwijdering van organische en anorganische stoffen door RO filtratie ( $>99 \%)$. De significante BGP reductie door ROgebaseerde behandeling werd bereikt ondanks de negatieve invloed van de nabehandeling op BGP van RO permeaat, welke is gestegen met $100 \%$ na de nabehandeling. Extra toevoegingen van organische en anorganische nutriënten door remineralisatie met behulp van de calciet contactors is geconstateerd (Hoofdstuk 4). Voor beide conventionele drinkwater en zeer-lage nutriënten water was organische koolstof de groei-beperkende nutriënt, zelfs met heel lage concentraties van fosfaat ( $<1 \mu \mathrm{g} / \mathrm{L}$ PO4-P) (Hoofdstuk 4). Naast het effect op BGP heeft water behandeling een invloed op de bacteriële gemeenschap van het drinkwater. Waarbij bacteriën aanwezig in RO behandeld water later zijn toegevoegd tijdens de nabehandeling, omdat geen van de bacteriën overeenkwam met de bacteriële gemeenschap van het bronwater (Hoofdstuk 4). Bovendien is gebleken dat de bepaling van 
BGP met behulp van zowel FCM als ATP vooral nuttig is omdat aanvullende informatie kan worden verkregen uit de gecombineerde tests. Bijvoorbeeld het effect van fosfaatbeperking op bacteriegroei, waarbij de cel opbrengst van fosfaat werd geschat op $0,70 \pm 0,05 \times 10^{9}$ cellen $/ \mu \mathrm{g} \mathrm{PO}_{4}-\mathrm{P}($ Hoofdstuk 5).

\section{Outlook}

Deze studie laat duidelijk zien dat RO filtratie voor het produceren van drinkwater veelbelovend is op het gebied van beperken van bacteriegroei in het water en de daarbij komende problemen voor gezondheid en onderhoud. Desondanks zijn maatregelen aanbevolen om de negatieve effect van nabehandeling te verminderen. Bijvoorbeeld gebruik van hoge kwaliteit calciet deeltjes voor remineralisatie ter voorkoming van toevoegingen van organische en anorganische nutriënten. Daarnaast is het aanbevolen om de aeratie torens vaker te onderhouden of alternatieve aeratie methodes (bijvoorbeeld membraan aeratie) te onderzoeken. 


\section{ACKNOWLEDGEMENT}

I would like to thank everybody who guided and supported me during this $\mathrm{PhD}$ journey. First of all, I would like to express my sincere gratitude to my promotors Prof. Walter G.J. van der Meer and Prof. Maria D. Kennedy for their academic supervision and guidance during the past years, which helped me in shaping my critical thinking and research skills, as well as for their support on the personal level. My thanks to my supervisors Dr. Sergio Salinas Rodríguez and Dr. Antoine J.B. Kemperman for their time and contribution to the practical aspects of my research as well as for the valuable input during the progress meetings and the writing process of my publications and thesis. I would like also to thank Prof. Jan C. Schippers for the valuable advice that he gave during the periodic progress meetings. Thank you my supervision team! My heartfelt appreciation goes also to my mentor Prof. Gang Liu for his endless support and help and for his valuable input to my publications. I have learnt a lot from your broad experience and knowledge in this topic, and from your experience in data analysis and scientific writing.

Thanks to Oasen Drinkwater for sponsoring my PhD research at IHE-Delft, as well as for facilitating my field work by installing and maintaining the pilot treatment unit that I have used during my research. My special thanks to the former and current Oasen team, namely, Harmen van der Laan, Willem Jan Knibbe, Peter Wessels and Jos Dusseldorp. Thanks to the professionals I worked with during the past year for the fruitful cooperation: Emmanuelle Prest (PWN Technologies), Aleksandra Knezev (Het Waterlaboratorium) and Rinnert Schurer (Evides).

Special thanks to the IHE-Delft laboratory staff for the endless support during my laboratory experiments as well as for the brainstorming and discussion sessions on research related topics. Thanks also for the talks and laughs during my laboratory times. Thank you Fred Kruis, Frank Wiegman, Peter Heerings, Ferdi Battes, Berend Lolkema and Lyzette Robbemont. In addition, I would like to thank Yuli Ekowati for her help in starting up my research. Thanks to the MSc and BSc students with whom I have worked for the fruitful working together: Ibrahim Chernor Bah, Angelinah Mohlago Moekwa, Arthur Devaux, Xander Buizert and Ali ben Hadi. Thanks to all IHE-Delft staff members for the support: Bianca Wassenaar mattie, Selvi Pransiska, Eldon Raj, Jolanda Boots, Floor Felix, Anique Karsten and others.

My thanks to my friends and colleagues in Delft for the unforgettable IHE-Delft moments together. Many thanks to Motasem Abushaban, Nasir Mangal and Mohanad Abunada for the help and the memories made inside and outside the laboratory. Thanks to my other laboratory friends for the nice memories: Ahmad Mahmoud, Iosif Skolluos, Prathna Chandrasekaran, Joyabrata Mal, Erika Espinosa, Rohan Jain, Nirajan Dhakal, Mauricio Barreto Carvajal, Mary Barrios Hernandez, Mulele Nabuyanda, and. Thanks as well for the 
other Palestinian friends for the nice gatherings: Alaa Ouda, Alaaeddin Swidan, Almohanad Abusultan, Mamoun Althuluth, Karam Abu Shammala, and Yousef Albuhaisi.

Thanks to my other dear friends for the support in the past years: Abeer Almomani, Ana Spataru, Angela Salinas, Aiske Rijnks, Adey Mersha, Andres and Megan, Alida Alves Beloqui, Bianca Wassenaar (mattie), Carlos Lopez Vazquez, Chris Metzker, Fernanda Braga, Thaine Herman Assumpção, Janaka (my brozer), Luana Cruz, Maria Salingay, Mohan Radhakrishnan, Nadine Sander, Nazanin Moradi, Neiler Medina Peña, Omar Andino, Stefan Siepman (the coach), Vanessa Gandarillas, Yvonne Hoiting (schattie patatie), and Yared Abeb. Special thanks to Monica Rodrigues for the continuous online support and encouragement. Thanks to my friends back home for motivating me from distance: Basil, Mohammed Shehada, Mohammed Abu Afifa, Deyaa, Salman, Khalid, Mohammed Shannan, Mohammed AlSaqqa and Majed.

This achievement would have not been possible without sports, so thanks to my friends from the football pitch, thanks to Berend and Irene my climbing team, and thanks to Nadine, Natalia, Audry and Alex Kaune my running team.

Thanks to my little Palestinian family in the Netherlands Walaa, Mohammed and the cute little Yasmina as well as to my other little family Berend, Shahnoor, and Safaa for always being there for me and for all the beautiful moments together. Thanks to my amigos for all nice fun and trips together: Angelica, Fer, Natalia, Can, Peter, Jeffery and Berend.

Finally and most importantly, I am very grateful to my family in Gaza for everything they have done for me in all stages of my life, which made it possible for me to reach this achievement. Big thanks and love to my mum and dad, also thanks to my brothers and sisters Moayad and Braa, Rana and Deema and to Ibrahim and finally to my beautiful nephews and nieces Zizo, Hamoud, Maya, Karkar, and Adam. 


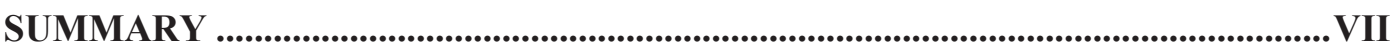

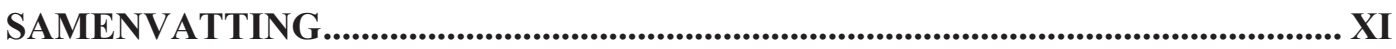

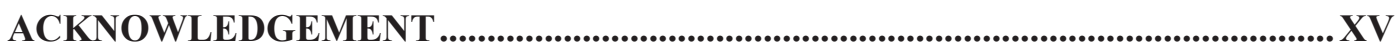

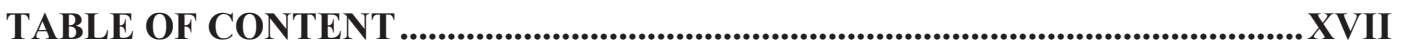

1 INTRODUCTION AND DISSERTATION OUTLINE ...........................................1

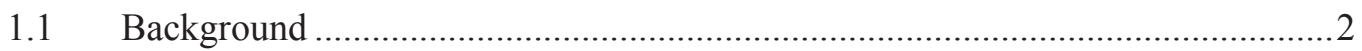

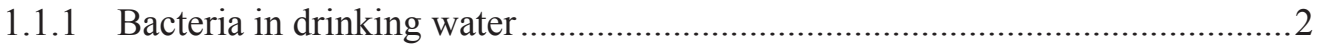

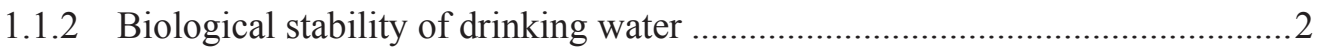

1.1.3 Reverse osmosis and remineralisation treatment ............................................ 4

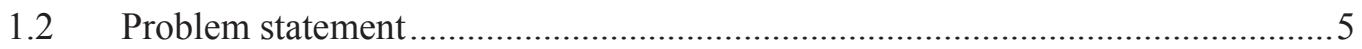

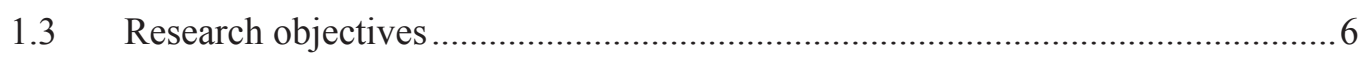

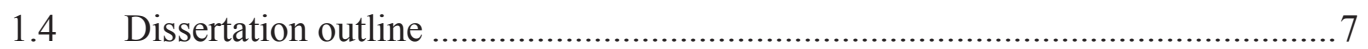

2 FURTHER DEVELOPING THE BACTERIAL GROWTH POTENTIAL METHOD FOR ULTRA-PURE DRINKING WATER PRODUCED BY REMINERALISATION OF REVERSE OSMOSIS PERMEATE................................9

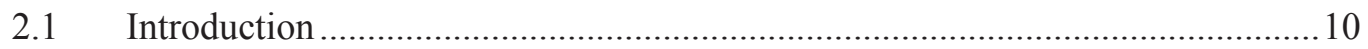

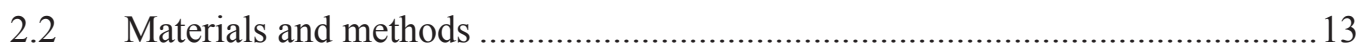

2.2.1 Conventional and RO-based water treatment .............................................. 13

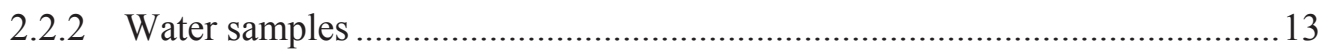

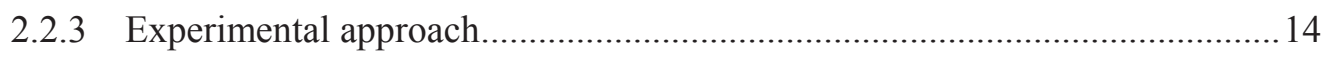

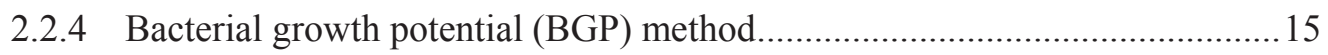

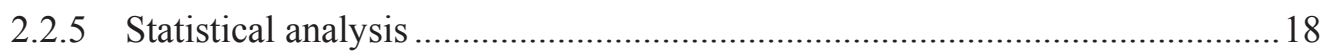

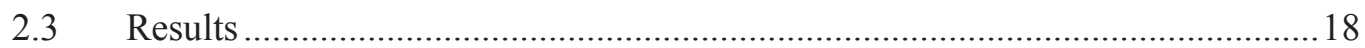

2.3.1 Laboratory remineralised RO permeate (lab-Remin) as an ultra-pure blank for

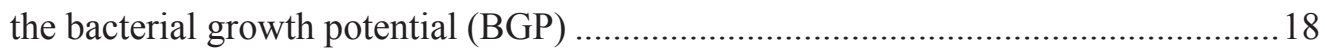

2.3.2 Influence of chemical addition and inoculation on BGP of lab-Remin blank 20

2.3.3 Effect of initial cell count on the BGP: Is there a need for pasteurisation? ....22

2.3.4 Case study: monitoring BGP of drinking water produced by $\mathrm{RO}$ and post-

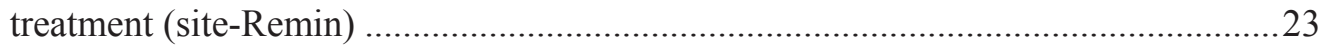

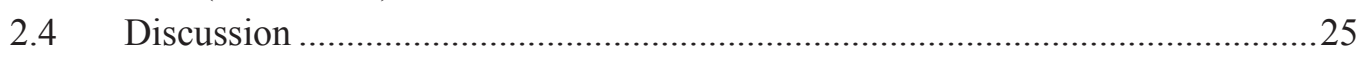

2.4.1 Composition of the ultra-pure lab-Remin blank and factors influencing the

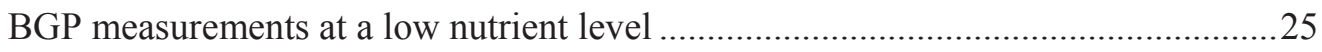

2.4.2 Comparing the ultra-pure lab-Remin blank with conventional blanks ...........27

2.4.3 Is there a need for pasteurisation as part of the BGP method? ......................29

2.4.4 Practical implications of measuring low levels of BGP..................................30 
3 MEASURING BACTERIAL GROWTH POTENTIAL OF ULTRA-LOW NUTRIENT DRINKING WATER PRODUCED BY REVERSE OSMOSIS: EFFECT OF SAMPLE PRE-TREATMENT AND BACTERIAL INOCULUM .......33

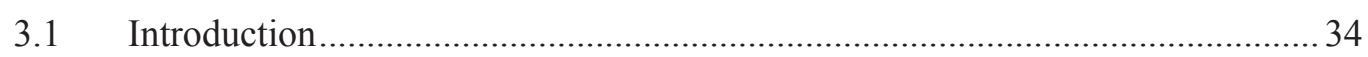

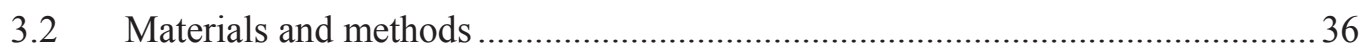

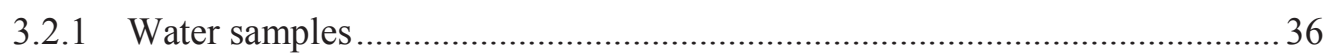

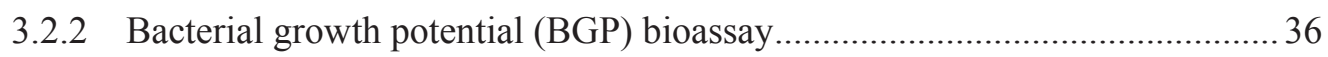

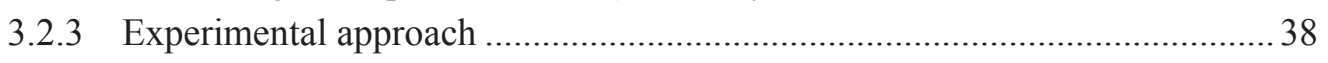

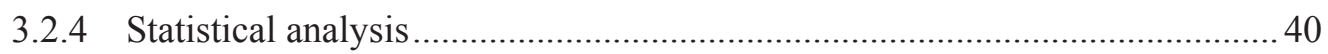

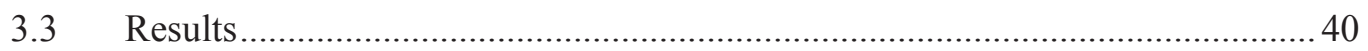

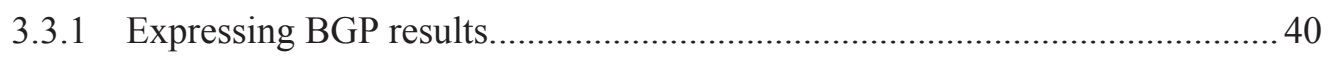

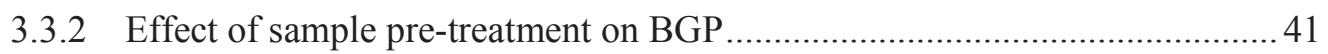

3.3.3 Assessing the ability of (remineralised) RO permeate bacteria to utilise

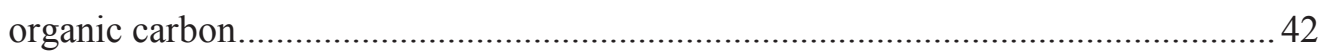

3.3.4 Monitoring BGP of conventionally treated and RO-treated drinking water... 47

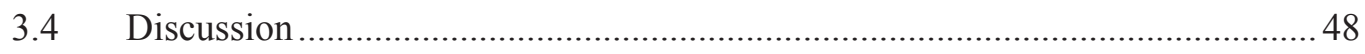

3.4.1 Effect of sample pre-treatment on BGP ..................................................... 49

3.4.2 The ability of bacteria originating from (remineralised) RO permeate to utilise

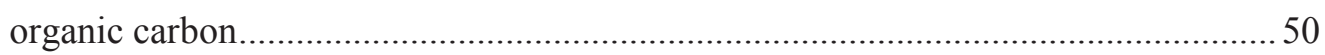

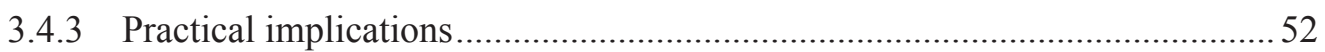

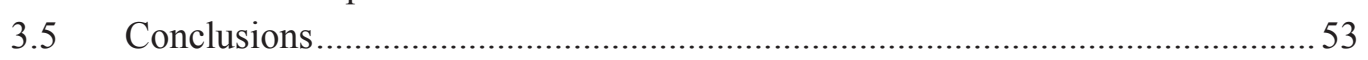

4 MULTI-PARAMETRIC ASSESSMENT OF BIOLOGICAL STABILITY OF DRINKING WATER PRODUCED FROM GROUNDWATER: REVERSE OSMOSIS VS. CONVENTIONAL TREATMENT ................................................55

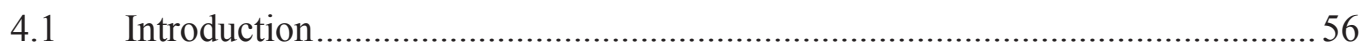

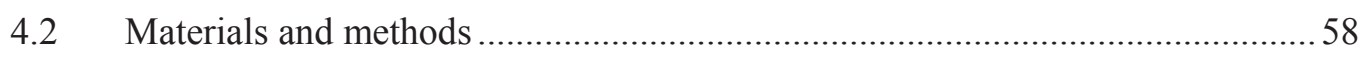

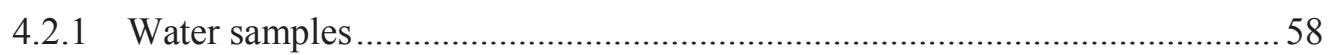

4.2.2 The multi-parametric comparison components …........................................ 58

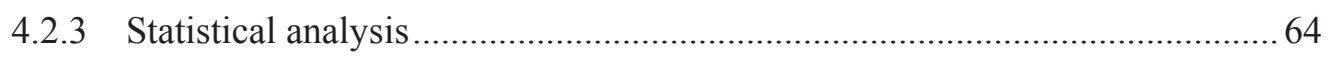

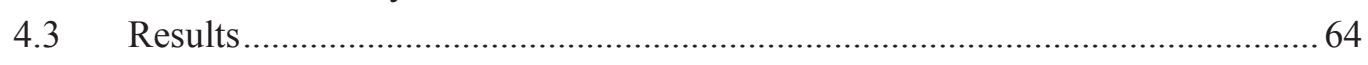

4.3.1 Intact cell count (ICC) and ATP concentration across treatment lines........... 64

4.3.2 BGP and nutrient composition of conventionally treated drinking water and

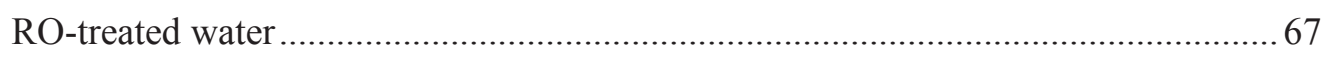

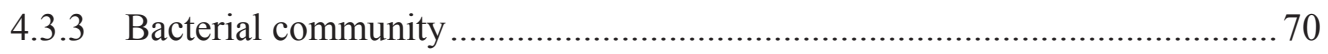

4.3.4 Correlation between nutrients and microbiological parameters ..................... 82

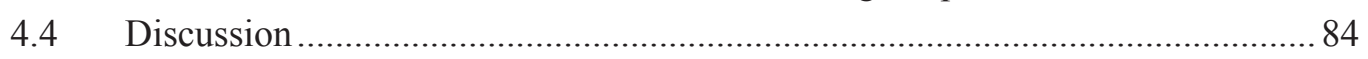

4.4.1 Characterisations of bacterial cells: ICC, ATP and ATP per cell.................... 84

4.4.2 BGP and the factors driving bacterial growth (nutrients) ............................... 85

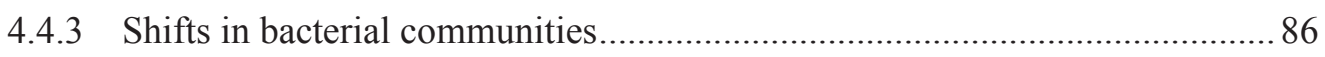


4.4.4 Practical insights for managing microbiological water quality......................8 87

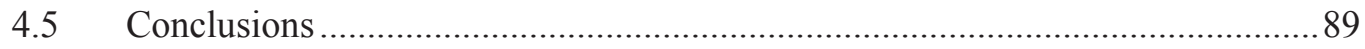

5 COMPARING THE BACTERIAL GROWTH POTENTIAL OF ULTRA-LOW NUTRIENT DRINKING WATER ASSESSED BY GROWTH TESTS BASED ON FLOW CYTOMETRIC INTACT CELL COUNT VERSUS ADENOSINE

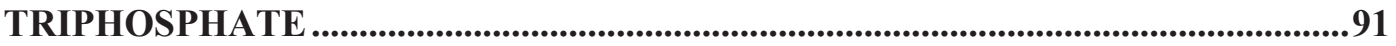

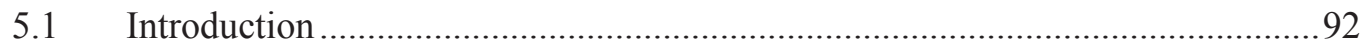

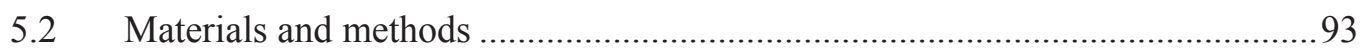

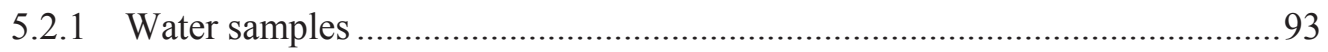

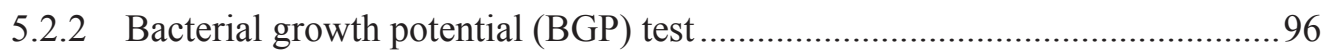

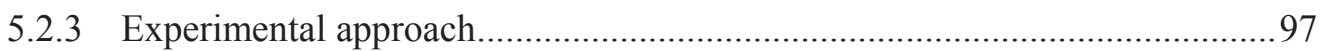

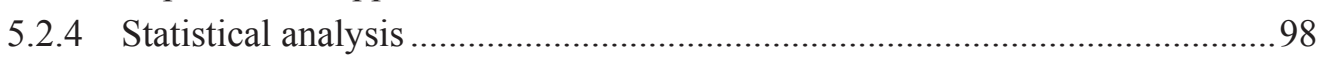

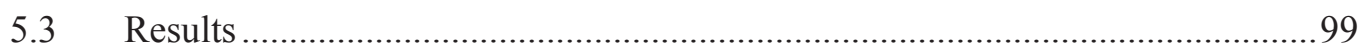

5.3.1 The ratio of BGPICC and BGPATP between Tap-water and RO-water.............99

5.3.2 The intact cell-yield (YICC) and ATP-yield (YATP) based on the growth curves

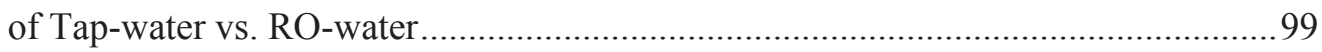

5.3.3 Growth-limiting nutrient identified by BGPICC and BGPATP for Tap-water vs.

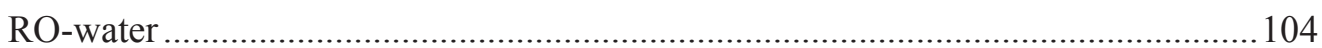

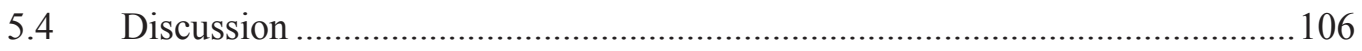

5.4.1 Reduction in BGPICC and BGPATP achieved by RO-based treatment ............106

5.4.2 The role of phosphate in bacterial growth and the maximum intact cell-yield

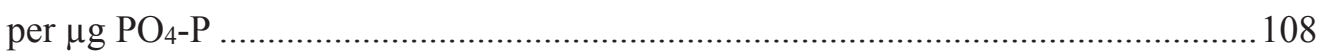

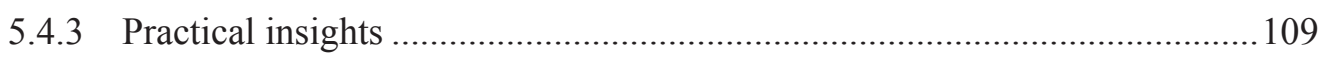

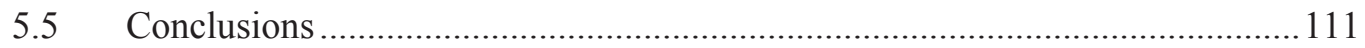

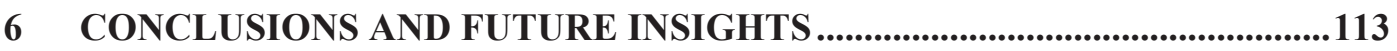

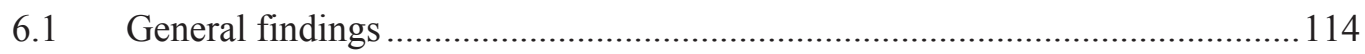

6.1.1 Bacterial growth potential method development .....................................115

6.1.2 Influence of reverse osmosis treatment on biological stability ....................116

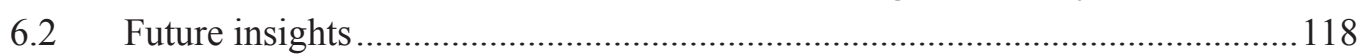

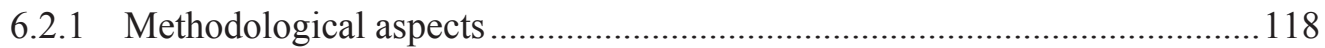

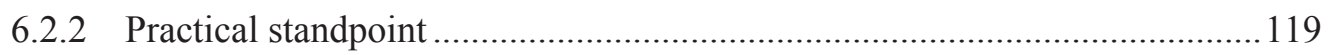

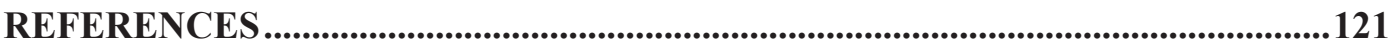

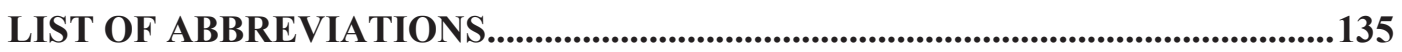

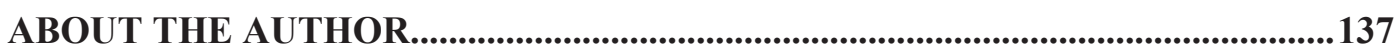



1

INTRODUCTION AND DISSERTATION OUTLINE 


\subsection{Background}

\subsubsection{Bacteria in drinking water}

Bacteria are natural inhabitants of source water as well as drinking water, most of which are not harmful for human health. However, several diseases related to the presence of pathogenic bacteria in drinking water have been identified since the end of the nineteenth century, such as the cholera disease and Legionnaires' disease (Colwell, 2004; Vree, 2007). Waterborne diseases urged the need for applying adequate water treatment prior to distributing drinking water for human consumption. The choice of water treatment strategy mainly depends on the source water used, e.g., (deep) groundwater, surface water (lakes, rivers), or seawater, aiming at the removal of microorganisms and (micro)pollutants, where chemical and microbiological characteristics may considerably differ among water sources and geographical locations (Rittmann et al., 1989).

Water utilities do not only aim at producing high quality drinking water that is safe for human consumption, but also maintaining this quality during distribution until water reaches the consumer's tap. Water distribution systems provide a complex environment for bacterial growth either in the form of planktonic bacteria or biofilm (Liu et al., 2013c), where such systems usually contain pipes of a wide range of diameters and made of various materials, in addition to the fluctuating water flow throughout the day. Several studies have shown that bacterial growth could take place in water distribution systems whether residual chlorine was added or not (Prest et al., 2016b).

\subsubsection{Biological stability of drinking water}

The concept of biological stability of drinking water appeared by the end of the twentieth century, where the issue of bacterial growth in water distribution networks has gained increasing attention. Biologically stable drinking water does not promote excessive bacterial growth in distribution systems and until water reaches the consumption point (Huck, 1990; Liu et al., 2013c; van der Kooij and Veenendaal, 2014). Several serious problems are associated with biologically unstable water, including threats posed to human health due to the growth of (opportunistic) pathogens, deterioration of the aesthetic aspects of water (taste, odour, and colour), and operational problems related to bio-corrosion of pipes and fittings (Volk and LeChevallier, 1999; Berry et al., 2006).

To prevent such problems, water utilities in several countries (e.g., USA, Australia, Italy, Spain) add residual disinfectant to the treated water just before leaving the production location to limit bacterial growth in their distribution systems. However, this strategy is associated with the formation of carcinogenic by-products as a result of the reaction between residual disinfectant and organic matter present in water (Rook, 1974; Havelaar et al., 2000; Sadiq and Rodriguez, 2004; Gopal et al., 2007). The formation of disinfection by-products can be minimised if a lower concentration of residual disinfectant is added. However, this 
Introduction and dissertation outline

approach might not assure full control of bacterial growth along the whole distribution system (LeChevallier et al., 1996). For this reason, a few European countries including the Netherlands avoid adding residual disinfectant in their water. Instead, they apply a multibarrier treatment strategy to reduce the concentration of nutrients that promote bacterial growth in water (Smeets et al., 2009; van der Kooij and Veenendaal, 2014). Moreover, permanent monitoring of water quality and a high maintenance level of distribution systems are practiced in these countries.

Biological stability of drinking water is traditionally assessed with the presumption that a small fraction of organic carbon is promoting bacterial growth. Several laboratory-based methods were developed to measure this fraction of organic carbon, namely assimilable organic carbon (AOC) method (van der Kooij et al., 1982; van der Kooij and Hijnen, 1984) and biodegradable dissolved organic carbon (BDOC) method (Servais et al., 1987). AOC is traditionally calculated based on the growth of two pure bacterial strains (P17 and NOX) in pasteurised water samples measured with the heterotrophic plate count (HPC) method, after which this growth can be converted into AOC concentration using a standard calibration curve. On the other hand, BDOC is directly calculated based on the consumption of dissolved organic carbon (DOC) during bacterial growth in a water sample. One of the main disadvantages of these traditional methods is the use of pure bacterial strains that might not completely consume the available organic carbon present in water, resulting in underestimation of bacterial growth that could take place in distribution systems where diverse bacterial strains are present.

Major developments in the field of microbiological methods have occurred in the past years, allowing for rapid, less laborious, and more accurate measurements of bacteria in water samples compared with the traditional HPC method (van Nevel et al., 2017). One of these major developments is flow cytometry (FCM) which can be coupled with DNA staining to enable complete enumeration of bacterial cells in a water sample (Prest et al., 2016a). FCM has been applied for biological stability assessment to measure AOC using natural bacterial consortium (Hammes and Egli, 2005), allowing for more accurate estimation of AOC. Additionally, FCM has been used for direct measurement of bacterial growth potential (BGP) of water expressed as cell count (cells $/ \mathrm{mL}$ ) (Prest et al., 2016a; Farhat et al., 2018; Nescerecka et al., 2018; Sousi et al., 2020a), without converting the obtained growth into AOC. BGP of water can also be measured with adenosine triphosphate (ATP) as an alternative bacterial parameter (Vital et al., 2012; Farhat et al., 2018; Abushaban et al., 2019). In addition, combining BGP measurements with 16 S rRNA gene sequencing enables in-depth understanding of bacterial growth characteristics of water during treatment and distribution (Li et al., 2017b; Liu et al., 2018; Liu et al., 2020). 
Introduction and dissertation outline

\subsubsection{Reverse osmosis and remineralisation treatment}

As mentioned in the previous section, applying extensive water treatment is the strategy followed in the Netherlands and other European countries to control bacterial growth in distribution systems. Conventionally, water treatment plants in the Netherlands apply a combination of several steps including coagulation, flocculation, sedimentation, and (rapid or slow) sand filtration to remove contaminants from water. Activated carbon filtration is applied to remove organic matter that causes colour and odour in water (Smeets et al., 2009; van der Kooij and Veenendaal, 2014; Vewin, 2017). In addition, disinfection by ultraviolet (UV) irradiation, ozonation, or even pre-chlorination is applied in some water treatment plants in the Netherlands to assure that bacteria are inactivated before water distribution.

Advanced water purification by membrane filtration is being increasingly used worldwide (Geise et al., 2010; Fane et al., 2015) and in the Netherlands (Schurer et al., 2019; Sousi et al., 2020a). Reverse osmosis (RO) is a semi-permeable membrane that is able to retain particles, inorganic/organic matter, microorganisms, and ions, resulting in an extremely pure product water. Since minerals including calcium and magnesium, and hydrogen carbonate are largely removed by RO filtration, RO permeate is considered unhealthy for human consumption (i.e., does not meet the WHO guidelines), aesthetically unacceptable in terms of taste, chemically unstable, and corrosive towards materials used in the public supply systems (Lahav and Birnhack, 2007; Birnhack et al., 2011). Thus, the use of RO permeate for human consumption without further post-treatment is not allowed by the Dutch drinking water law.

Post-treatment is a key process to make RO permeate potable and suitable for distribution. The process of re-adding the essential minerals to RO permeate is called remineralisation, which can be conducted using several methods, including: blending RO permeate with source water, direct dosing of chemicals, calcite contactors, and micronized calcite dosing. This research focuses on remineralisation by calcite contactors, where RO permeate percolates through a calcite bed to dissolve calcium carbonate into calcium $\left(\mathrm{Ca}^{2+}\right)$ ions and hydrogen carbonate $\left(\mathrm{HCO}_{3}^{-}\right)$. Remineralisation by calcite contactors is widely applied in practice since it is a simple and cost-efficient method (Hasson and Bendrihem, 2006; Ruggieri et al., 2008).

Research has shown that bacterial growth-promoting nutrients could be considerably removed by RO filtration, resulting in a very low level of bacterial growth in RO permeate (Escobar et al., 2000; Park and Hu, 2010; Dixon et al., 2012; Thayanukul et al., 2013). However, this may be influenced by post-treatment, more specifically by remineralisation since it involves the addition of substances to RO permeate. To the best of our knowledge, no research has been conducted to assess the potential influence of remineralisation on the bacterial growth potential of RO permeate. 
Introduction and dissertation outline

\subsection{Problem statement}

Although the current drinking water leaving treatment locations in the Netherlands meets the "golden" standards set using the traditional methods for biological stability assessment (e.g., AOC $<10 \mu \mathrm{g} / \mathrm{L}$ as acetate carbon), significant bacterial growth took place in water distribution systems, posing a threat to human health (van der Wielen and van der Kooij, 2010; Beauté et al., 2013). Therefore, there is a need to improve water treatment in the Netherlands by applying advanced technologies such as membrane filtration process including reverse osmosis (RO), after which water has an ultra-low nutrient content (Escobar et al., 2000; Peng and Escobar, 2003; Thayanukul et al., 2013).

RO filtration is a leading technology for producing drinking water from seawater and brackish groundwater with nearly two thirds of the desalination capacity worldwide (Villacorte et al., 2015; Anis et al., 2019). However, there is currently a limited number of studies about the bacterial growth characteristics of RO permeate, especially after remineralisation, which is required to assess the reduction in bacterial growth potential (BGP) with RO-based treatment (RO filtration and remineralisation) compared with the conventional treatment that is currently applied. Assessing bacterial growth potential of (remineralised) RO permeate requires investigating the applicability of the current methods for this type of ultra-low nutrient water and, if needed, further developing them to ensure reliable results. This includes possible challenges of lowering the detection limit of the method and minimising the adverse effect of methodological aspects on bacterial growth potential measurement at low levels.
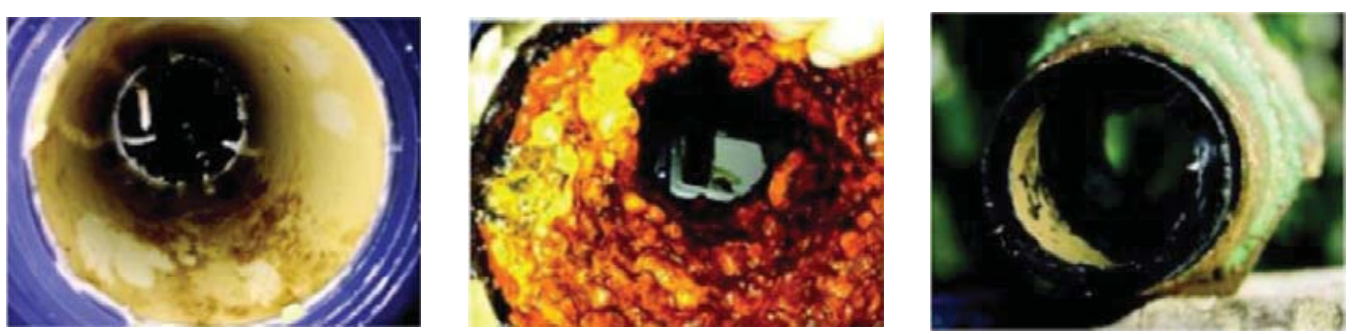

Figure 1.1. Examples of bacterial growth on the inner surface of pipes made of different materials (Liu et al., 2017). 


\subsection{Research objectives}

The overall aim of this research was to investigate how RO-based treatment (i.e., RO filtration and remineralisation) may improve the biological stability of drinking water compared with the current conventional water treatment. This involved further developing the current methodologies for assessing biological stability with main focus on bacterial growth potential (BGP) measurement using flow cytometry (FCM). Additional methodologies such as BGP measurement using ATP, and 16S rRNA gene sequencing were also explored during this research.

The aforementioned aim was achieved by studying two water treatment schemes: full-scale conventional $\left(340 \mathrm{~m}^{3} / \mathrm{h}\right)$ and pilot-scale RO-based $\left(7 \mathrm{~m}^{3} / \mathrm{h}\right)$, at the Kamerik drinking water treatment plant in the Netherlands (Oasen Drinking Water Company). Both schemes were fed with the same anaerobic groundwater source.

The specific objectives of the study were to:

i. Further develop the BGP method using FCM for the application of water treated by RO and remineralisation, including the following aspects:

- Lowering the detection limit of the method by investigating several blank waters.

- Investigating the effect of pre-treatment prior to BGP measurement on the nutrient composition. Several methods were compared, including: pasteurisation, autoclaving, and membrane filtration.

- Investigating the ability of bacteria originating from remineralised RO permeate to utilise organic carbon with various complexity levels.

ii. Propose a multi-parametric approach to evaluate biological stability of water treated by RO and remineralisation as well as the current conventional drinking water. This approach includes the changes in bacterial quantification and growth potential, nutrient concentration and composition, and the bacterial community composition and diversity across steps in both treatment types.

iii. Explore the combination of BGP measurement using both FCM and ATP, to obtain in-depth understanding of bacterial growth characteristics of water treated by RO and remineralisation. 
Introduction and dissertation outline

\subsection{Dissertation outline}

This dissertation has been structured in six chapters, as follows:

Chapter 1 provides a brief background about the topic of biological stability and highlights the problem and research gaps in this topic with regard to assessing biological stability of ultra-low nutrient water produced by RO and remineralisation. This chapter also introduces the specific objectives of this study.

Chapter 2 investigates the current detection limit of the BGP method, and explores how to lower it for the application of ultra-low nutrient water produced by RO and remineralisation, by examining different blank waters.

Chapter 3 investigates developing methodological aspects for measuring BGP of ultra-low nutrient water produced by RO and remineralisation, namely, pre-treatment and inoculation.

Chapter 4 presents the results of the multi-parametric approach proposed to evaluate the biological stability of drinking water. Research has been conducted at an existing water treatment plant in the Netherlands, where full-scale conventional and pilot-scale RO-based treatment schemes are operating.

Chapter 5 compares measuring BGP using FCM and ATP methods for ultra-low nutrient RO-treated water as well as for conventional drinking water.

Chapter 6 summarizes the main conclusions drawn from this study and provides possible directions for future research. 



\section{2}

\section{FURTHER DEVELOPING THE BACTERIAL GROWTH POTENTIAL METHOD FOR ULTRA-PURE DRINKING WATER PRODUCED BY REMINERALISATION OF REVERSE OSMOSIS PERMEATE}

\section{This chapter is based on the following publication:}

Sousi, M., Liu, G., Salinas-Rodriguez, S.G., Knezev, A., Blankert, B., Schippers, J.C., van der Meer, W., Kennedy, M.D., 2018. Further developing the bacterial growth potential method for ultra-pure drinking water produced by remineralisation of reverse osmosis permeate. Water Research 145, 687-696. https://doi.org/10.1016/j.watres.2018.09.002 
Further developing the bacterial growth potential method for ultra-pure drinking water produced by remineralisation of reverse osmosis permeate

\begin{abstract}
Ensuring the biological stability of drinking water is essential for modern drinking water supply. To understand and manage the biological stability, it is critical that the bacterial growth in drinking water can be measured. Nowadays, advance treatment technologies, such as reverse osmosis (RO), are increasingly applied in drinking water purification where the produced water is characterised by low levels of nutrients and cell counts. The challenge is, therefore, how to measure the low bacterial growth potential (BGP) of such ultra-pure water using the available methods which were originally developed for conventionally treated drinking water. In this study, we proposed a protocol to assess BGP of ultra-pure drinking water produced by $\mathrm{RO}$ and post-treatment (including remineralisation). Natural bacterial consortium from conventional drinking water was added to all water samples during this study to ensure the presence of a wide range of bacterial strains. The method development included developing an ultra-pure blank with high reproducibility to lower the detection limit of the BGP method $\left(50 \pm 20 \times 10^{3} \mathrm{ICC} / \mathrm{mL}\right)$ compared with conventional blanks such as bottled spring water, deep groundwater treated by aeration and slow sand filtrate of surface water supply. The ultra-low blank consists of RO permeate after adjusting its $\mathrm{pH}$ and essential mineral content under controlled laboratory conditions to ensure carbon limitation. Regarding the test protocol, inoculum concentrations of $>10^{4} \mathrm{ICC} / \mathrm{mL}$ may have a significant contribution to the measured low levels of BGP. Pasteurisation of water samples before measuring BGP is necessary to ensure reliable bacterial growth curves. The optimised method was used to assess BGP of ultra-pure drinking water produced by RO membranes and post-treatment (including remineralisation), where the BGP has decreased by $85 \%$ to a level of $90 \pm 20 \times 10^{3} \mathrm{ICC} / \mathrm{mL}$ compared with conventionally treated water $\left(630 \pm 70 \times 10^{3} \mathrm{ICC} / \mathrm{mL}\right)$.
\end{abstract}

\title{
2.1 Introduction
}

Bacterial (re)growth in drinking water supply systems may lead to problems, such as health threats by (opportunistic) pathogens, aesthetic deterioration of water taste and odour, biocorrosion of pipes and fittings, and nitrification processes (Volk and LeChevallier, 1999; Berry et al., 2006). Currently, this unwanted bacterial growth is being managed either by maintaining disinfectant residuals which may react with organic compounds in drinking water and form hazardous disinfection by-products (DBPs) (Havelaar et al., 2000; Sadiq and Rodriguez, 2004; Gopal et al., 2007), or through producing biologically stable drinking water that contains low concentrations of readily available nutrients for bacterial growth (van der Kooij, 2000; Hammes et al., 2010a; Liu et al., 2013c), e.g., assimilable organic carbon (AOC) below $10 \mu \mathrm{g} / \mathrm{L}$ Ac-C (van der Kooij, 1992). 
Further developing the bacterial growth potential method for ultra-pure drinking water produced by remineralisation of reverse osmosis permeate

To understand the bacterial (re)growth during distribution and to develop efficient management strategies, it is essential to be able to measure and quantify this (re)growth. Until now, several batch tests have been developed to assess the potential of drinking water to support bacterial growth using different techniques to measure the increase in cell abundance. These techniques include: turbidity (Withers and Drikas, 1998; Page et al., 2002), colony count (van der Kooij et al., 1982; Joret et al., 1991; van der Kooij, 1992; Sack et al., 2010; Sack et al., 2011), biomass volume (Servais et al., 1987), cell number (Hammes and Egli, 2005; Dixon et al., 2012; Park et al., 2016; Prest et al., 2016a), and cell activity based on adenosine triphosphate (ATP) (van der Kooij and Veenendaal, 2001; 2014; van der Kooij et al., 2017). Employing flow cytometry (FCM) for cell count was evaluated and applied in BGP tests (Dixon et al., 2012; Prest et al., 2016a) because of its advantages of being simple, rapid, reproducible and informative (Prest et al., 2013; van Nevel et al., 2017).

Regardless of the test type and the parameter to be measured, each conducted test to assess the potential of drinking water to support bacterial growth requires using a blank, ideally nutrient-free water, which defines the detection limit of the method to obtain reliable and reproducible results. Bottled spring water (Evian, France) has been widely investigated and used as a blank for BGP measurements due to its low nutrient content (Hammes and Egli, 2005; Vital et al., 2007; Bucheli-Witschel et al., 2012; Elhadidy et al., 2016; Prest et al., 2016a; Farhat et al., 2018). In addition, two water types collected at water treatment plants in the Netherlands, namely deep groundwater treated by aeration and slow sand filtrate of surface water supply, have been used as blanks because of their low nutrient content (Bereschenko and Hornstra, 2014; Guo et al., 2014; Mikkers and Magic-Knezev, 2014; van der Kooij et al., 2014). Table 2.1 presents the characteristics of each blank.

Table 2.1. Characteristics of the conventional blanks used for biological stability assessment tests.

\begin{tabular}{|c|c|c|c|c|c|}
\hline Water & $\begin{array}{l}\mathrm{pH} \\
(-)\end{array}$ & $\begin{array}{l}\text { DOC } \\
(\mathrm{mg} / \mathrm{L})\end{array}$ & $\begin{array}{l}\text { AOC } \\
(\mu g / L \text { Ac-C) }\end{array}$ & $\begin{array}{l}\mathrm{BPP}_{14} \\
(\mathrm{ng} \mathrm{ATP} / \mathrm{L})\end{array}$ & $\begin{array}{l}\text { BGP } \\
\left(\times 10^{3} \text { cells } / \mathrm{mL}\right)\end{array}$ \\
\hline $\begin{array}{l}\text { Bottled spring water } \\
\text { (Evian, France) }\end{array}$ & $\sim 7.90$ & $<0.2$ & $10-52^{a}$ & n.a. ${ }^{\mathrm{c}}$ & $\begin{array}{l}133 \pm 18 \\
\text { (net growth) }\end{array}$ \\
\hline $\begin{array}{l}\text { Deep groundwater treated } \\
\text { by aeration }\end{array}$ & $\sim 7.95$ & $0.17-0.4$ & $\sim 1^{\mathrm{b}}$ & $5-10$ & $\begin{array}{l}100-350 \\
\text { (max. growth) }\end{array}$ \\
\hline $\begin{array}{l}\text { Slow sand filtrate of } \\
\text { surface water supply }\end{array}$ & $\sim 8.45$ & $1.7-2.3$ & $3-5^{b}$ & $30-40$ & $\begin{array}{l}\text { 250-600 } \\
\text { (max. growth) }\end{array}$ \\
\hline $\begin{array}{l}\text { DOC: dissolved ors } \\
\text { BGP: bacterial grow } \\
{ }^{\mathrm{a}} \text { AOC (natural bacte } \\
{ }^{\mathrm{b}} \text { AOC (P17/NOX) } \\
{ }^{\mathrm{c}} \text { n.a., not available }\end{array}$ & $\begin{array}{l}\text { ic carbol } \\
\text { otential } \\
\text { consort } \\
\text { der Koo }\end{array}$ & $\begin{array}{l}\text { assimilabl } \\
\text { mmes and I } \\
982 \text { ) }\end{array}$ & $\begin{array}{l}\text { rganic carbon; } \\
\text { i, 2005) }\end{array}$ & biomass produ & potential; \\
\hline
\end{tabular}


Further developing the bacterial growth potential method for ultra-pure drinking water produced by remineralisation of reverse osmosis permeate

Although the lowest reported BGP of those blanks is $100 \times 10^{3}$ cells $/ \mathrm{mL}$, they are still adequate and reliable blanks for drinking water produced by conventional treatment processes with BGP reaching levels of $300 \times 10^{3}-700 \times 10^{3}$ cells $/ \mathrm{mL}$ (Prest et al., 2016a; Nescerecka et al., 2018). However, this becomes problematic if the BGP of treated drinking water decreases below $100 \times 10^{3}$ cells $/ \mathrm{mL}$ as the measurements will no longer be reliable. Drinking water produced by reverse osmosis (RO) is an example of such water with considerably low BGP (Park and Hu, 2010; Dixon et al., 2012) due to the high efficiency of RO to retain bacterial cells (Madaeni, 1999; van der Bruggen and Vandecasteele, 2003; Park and $\mathrm{Hu}, 2010$ ) and the AOC content (Escobar et al., 2000; Hong et al., 2005; Thayanukul et al., 2013). Being unable to measure the low levels of BGP with high reliability might limit our understanding of the bacteriological water quality of such ultra-pure water and factors affecting it. For instance, post-treatment of RO permeate including remineralisation and aeration may have a significant impact on its original quality, which cannot be affirmed with conventional blanks. Therefore, it is highly necessary to lower the detection limit of the BGP method, by introducing an ultra-pure blank with a much lower BGP. This is especially true when looking at the increasing number of advanced treatment processes in water utilities, including RO treatment plants (Villacorte et al., 2015), in response to more stringent water quality regulations, advances in water treatment technologies, and increasing awareness of water quality deterioration during distribution (Liu et al., 2017).

Moreover, there are other variations in the test conditions of current BGP methods, all of which may influence the measurement and detection limit of the method, such as (i) inactivation procedures of indigenous bacteria (e.g. pasteurisation, filtration or no pretreatment) and (ii) introduction of various inoculum types (if applicable). For instance, pasteurisation is needed to inactivate natural bacteria before inoculating with pure bacterial strains for AOC measurements (van der Kooij et al., 1982; van der Kooij, 1992; Sack et al., 2010; Sack et al., 2011), whereas filtration is mainly practiced when total inactivation of natural bacteria is unnecessary, which is especially true when using a natural bacterial consortium for inoculation (Hammes and Egli, 2005; Farhat et al., 2018).

The main objective of the present study is to develop a protocol to assess the BGP of ultrapure drinking water. The research focused on: (i) lowering the detection limit of the method by using RO permeate, after adjusting its chemical water quality at the laboratory, as a blank, (ii) assessing the need for pre-treatment (i.e., pasteurisation) of water samples prior to measuring BGP, and (iii) evaluating the contribution of inoculation to the BGP measurements. Finally, the developed protocol was applied to evaluate the change in BGP of remineralised RO permeate from a pilot treatment system operated at a drinking water pumping station in the Netherlands. 
Further developing the bacterial growth potential method for ultra-pure drinking water produced by remineralisation of reverse osmosis permeate

\subsection{Materials and methods}

\subsubsection{Conventional and RO-based water treatment}

This study was conducted at one of the water treatment plants of Oasen Drinkwater (the Netherlands). Currently, the anaerobic groundwater is treated by conventional water treatment processes at a capacity of $340 \mathrm{~m}^{3} / \mathrm{h}$. The treatment comprises aeration, rapid sand filtration, softening, granular activated carbon (GAC) filtration, and UV disinfection.

At the same location, a pilot-scale RO-based water treatment unit $\left(7 \mathrm{~m}^{3} / \mathrm{h}\right)$ is operated in parallel, which consists of anaerobic RO filtration (Hydranautics ESPA2-LD-4040) with $75 \%$ total recovery, followed by ion exchange ( $1.4 \mathrm{~m}^{3}$ of LEWATIT S 2568 synthetic resin) for further removal of ammonium, remineralisation using traditional calcite contactors for the addition of calcium $\left(40 \mathrm{mg} / \mathrm{L} \mathrm{Ca}^{2+}\right)$ and hydrogen carbonate $\left(122 \mathrm{mg} / \mathrm{L} \mathrm{HCO}_{3}^{-}\right)$, magnesium dosing ( $4 \mathrm{mg} / \mathrm{L} \mathrm{Mg}^{2+}$ ), and lastly tower aeration (packed with $1.24 \mathrm{~m}^{3}$ of $38-8$ plastic Raflux-Rings) for stripping out methane gas $\left(\mathrm{CH}_{4}\right)$ present naturally in the groundwater and excess carbon dioxide $\left(\mathrm{CO}_{2}\right)$ dosed before the calcite contactors for efficient dissolution of calcite grains.

The term post-treatment used during this study refers to all the treatment units after RO filtration, including ion exchange, remineralisation and aeration. The final $\mathrm{pH}$ of the product water of both treatment schemes is $7.8 \pm 0.2$.

\subsubsection{Water samples}

Water samples, including conventionally treated groundwater (CTW), groundwater collected directly after RO filtration (RO permeate) and post-treated RO permeate at the site, i.e., RO permeate after passing ion exchange, remineralisation, and aeration (siteRemin), were collected at the water treatment location in the period between October 2016 and April 2017.

In addition, four AOC-low waters were tested as blanks for the BGP measurements, including conventional blanks, i.e., bottled Evian water (BEW), deep groundwater (DGW) treated by aeration, and slow sand filtrate of surface water supply (SSF), and the ultra-pure blank proposed in this study, i.e., RO permeate after making the necessary chemical adjustments of $\mathrm{pH}$ and mineral content at the laboratory (as described in the following sections and referred to as lab-Remin). The total number of water samples collected during the study period was 69 including the site samples and blanks.

A list of the 6 water types of the current study and their characteristics is given in Table 2.2. 
Further developing the bacterial growth potential method for ultra-pure drinking water produced by remineralisation of reverse osmosis permeate

Table 2.2. Description, coding, and composition of water samples collected during the current study.

\begin{tabular}{|c|c|c|c|c|c|c|}
\hline Sample description & Code & $\mathbf{n}$ & $\begin{array}{l}\text { pH } \\
(-)\end{array}$ & $\begin{array}{l}\text { TDS } \\
(\mathrm{mg} / \mathrm{L})\end{array}$ & $\begin{array}{l}\text { DOC } \\
(\mathrm{mg} / \mathrm{L})\end{array}$ & $\begin{array}{l}\text { Added P, N } \\
(\mu \mathrm{g} / \mathrm{L})\end{array}$ \\
\hline $\begin{array}{l}\text { Conventionally treated } \\
\text { groundwater }\end{array}$ & CTW & 16 & 7.80 & 400 & $6.2^{\mathrm{a}}$ & - \\
\hline $\begin{array}{l}\text { Post-treated RO permeate with } \\
\text { ion exchange, remineralization, } \\
\text { and aeration }\end{array}$ & site-Remin & 13 & 7.80 & 150 & $<0.3^{\mathrm{a}}$ & - \\
\hline Bottled Evian water & BEW & 7 & 7.90 & 350 & $<0.2$ & 5,50 \\
\hline Deep groundwater & DGW & 2 & 7.95 & n.a. ${ }^{b}$ & $0.17-0.4$ & 5,50 \\
\hline $\begin{array}{l}\text { Slow sand filtrate of surface } \\
\text { water supply }\end{array}$ & SSF & 2 & 8.45 & n.a. ${ }^{b}$ & $1.7-2.3$ & 5,50 \\
\hline Lab-remineralized RO permeate & lab-Remin & 19 & 7.80 & 140 & $<0.3^{\mathrm{a}}$ & 5,50 \\
\hline
\end{tabular}

\footnotetext{
${ }^{a}$ Measured during this study

${ }^{\mathrm{b}}$ n.a., not available
}

\subsubsection{Experimental approach}

The experimental approach is shown in Figure 2.1.

Firstly, the ultra-pure blank (lab-Remin) was compared with conventional blanks (BEW, DGW, and SSF), specifically in terms of BGP.

Secondly, the factors affecting BGP of the lab-Remin blank were studied, including the undesired addition of nutrients during chemical adjustments of the lab-Remin blank which was assessed by varying the concentrations of $\mathrm{NaHCO}_{3}$, namely: 61, 122 (selected for this study), 183 and $244 \mathrm{mg} / \mathrm{L} \mathrm{HCO}_{3}^{-}$. The $\mathrm{pH}$ remained constant at $7.8 \pm 0.2$ to guarantee that any differences can be attributed to chemical impurities. A similar approach was followed to study the undesired addition of nutrients during inoculating the lab-Remin blank with a natrual bacterial community from fresh CTW. This effect was assessed for several inoculum concentrations, namely: $0.5 \times 10^{3}$ (lowest), $1 \times 10^{3}, 2 \times 10^{3}, 5 \times 10^{3}, 10 \times 10^{3}$ (selected for this study), $20 \times 10^{3}$, and $50 \times 10^{3}$ (highest, to ensure obtaining a significant impact) $\mathrm{ICC} / \mathrm{mL}$, as compared with the non-inoculated lab-Remin blank. The theoretical increase in

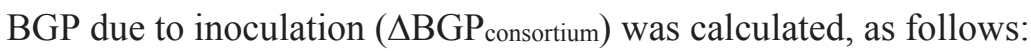

$$
\Delta \mathrm{BGP}_{\text {consortium }}=\left(\mathrm{V}_{1} / \mathrm{V}_{2}\right) \times \mathrm{BGP}_{\mathrm{CTW}}
$$

In this expression, $\mathrm{V}_{1}$ and $\mathrm{V}_{2}$ represent volumes of CTW added and lab-Remin blank sample, respectively. $\mathrm{BGP}_{\mathrm{CTW}}$ is the average BGP measured for CTW. 
Further developing the bacterial growth potential method for ultra-pure drinking water produced by remineralisation of reverse osmosis permeate

Thirdly, the effect of initial cell count on bacterial growth was studied by analysing all water samples with and without pasteurisation and observing the resulting bacterial growth curves.

And lastly, the developed method was applied to assess the BGP of ultra-pure drinking water produced by RO membranes and post-treatment (site-Remin) collected at different times (i.e., $0,1,2,3,24,48,72,96,264$, and $336 \mathrm{~h}$ ) after refilling the calcite contactors with fresh calcite grains. The purpose of the latter test was to confirm the applicability of the developed method and ultra-pure blank to reliably assess the BGP of such drinking water.

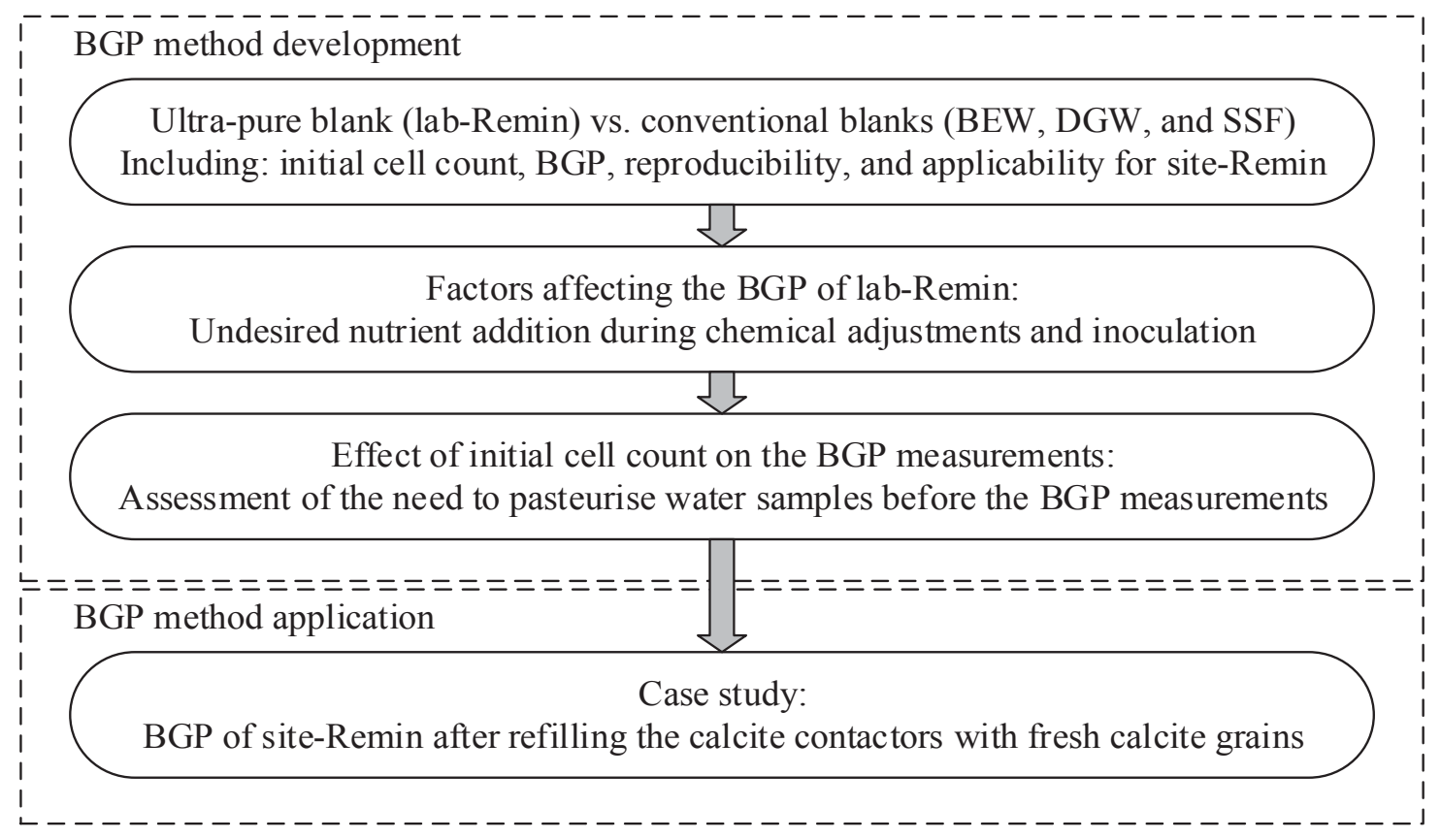

Figure 2.1. The experimental approach to develop and apply the bacterial growth potential (BGP) method for ultra-pure drinking water after RO and post-treatment.

\subsubsection{Bacterial growth potential (BGP) method}

AOC-free materials: Glassware used for sampling (Duran ${ }^{\circledR}$ graduated clear glass bottles with screw plastic cap) and incubation (clear glass vials with screw plastic cap) of water samples was made AOC-free as described in previous studies (Weinrich et al., 2009; Prest et al., 2016a). In short, the glassware was washed with a cleaning solution (Alconox ${ }^{\circledR}$ detergent, $10 \mathrm{~g} / \mathrm{L}$ in ultrapure water), rinsed three times with ultrapure water (Milli- $\mathrm{Q}^{\circledR}$ water, Merck Millipore), air-dried overnight, and heat treated in a muffle oven at $550{ }^{\circ} \mathrm{C}$ for $6 \mathrm{~h}$. The plastic lids were cleaned by soaking in heated $\left(60^{\circ} \mathrm{C}\right)$ sodium persulfate solution $\left(\mathrm{Na}_{2} \mathrm{~S}_{2} \mathrm{O}_{8}, 100 \mathrm{~g} / \mathrm{L}\right)$ for $1 \mathrm{~h}$, rinsing three times with ultrapure water, and air drying. 
Further developing the bacterial growth potential method for ultra-pure drinking water produced by remineralisation of reverse osmosis permeate

Moreover, all preparations and procedures for the BGP test were conducted in a clean laboratory environment to avoid air-borne contamination.

Preparation of stock solutions: To create a lab-Remin blank, four different inorganic stock solutions were prepared in AOC-free bottles using ultrapure water (i.e., Milli-Q water) with final concentrations of $67.2 \mathrm{~g} / \mathrm{L} \mathrm{NaHCO}_{3}$ (for $\mathrm{pH}$ adjustment and buffer addition), $294 \mathrm{~g} / \mathrm{L}$ $\mathrm{CaCl}_{2} \cdot 2 \mathrm{H}_{2} \mathrm{O}$ and $67 \mathrm{~g} / \mathrm{L} \mathrm{MgCl} \cdot 6 \mathrm{H}_{2} \mathrm{O}$ (for calcium and magnesium addition), $0.219 \mathrm{~g} / \mathrm{L}$ $\mathrm{KH}_{2} \mathrm{PO}_{4}$ (for phosphate addition), and $3.607 \mathrm{~g} / \mathrm{L} \mathrm{KNO}_{3}$ (for nitrogen addition). The prepared stock solutions were kept in the fridge at $4{ }^{\circ} \mathrm{C}$ and were used for multiple experiments. Reagent grade chemicals ( $>99 \%$ purity) were used throughout this study (J.T.Baker ${ }^{\circledR}$ Reagents Salts, ACS Grade, the USA).

Preparation of blanks: The ultra-pure blank, lab-Remin, was prepared by adjusting the $\mathrm{pH}$ and mineral content of $\mathrm{RO}$ permeate by the addition of $2.5 \mu \mathrm{L} / \mathrm{mL}$ of $\mathrm{NaHCO}_{3}$ and 0.5 $\mu \mathrm{L} / \mathrm{mL}$ of $\mathrm{CaCl}_{2}$ and $\mathrm{MgCl}_{2}$ stock solutions to achieve identical concentrations of the corresponding elements in site-Remin (final $\mathrm{pH}$ of $7.8 \pm 0.2$, buffer of $122 \mathrm{mg} / \mathrm{L} \mathrm{HCO}_{3}{ }^{-}$, final concentrations of $40 \mathrm{mg} / \mathrm{L} \mathrm{Ca}^{2+}$ and $4 \mathrm{mg} / \mathrm{L} \mathrm{Mg}^{2+}$ ). Moreover, phosphate $\left(5 \mu \mathrm{g} / \mathrm{L} \mathrm{PO}_{4-}\right.$ P) and nitrogen (50 $\mu \mathrm{g} \mathrm{N} / \mathrm{L})$ were added to the blanks (BEW, DGW, SSF and lab-Remin) to guarantee growth limitation by organic carbon up to $500 \mu \mathrm{g} / \mathrm{L}$ Ac-C (C:N:P $=100: 10: 1$, (Hammes and Egli, 2005)). $\mathrm{P}$ and $\mathrm{N}$ were added by dosing $0.1 \mu \mathrm{L} / \mathrm{mL}$ of both $\mathrm{KH}_{2} \mathrm{PO}_{4}$ and $\mathrm{KNO}_{3}$ stock solutions. The blanks are made carbon-limited to ensure detecting any potential carbon contaminations during the handling of samples, which comes in different forms such as: (i) carbon attached to the glassware and caps, (ii) volatile carbon present in the laboratory environment, and (iii) carbon contamination present in reagent grade chemicals used in the laboratory, in addition to the original carbon content of the blanks.

Sample pre-treatment and inoculation: To evaluate the influence of initial cell count on the BGP measurements, all water types (CTW, site-Remin, BEW, DGW, SSF, and labRemin) were analysed both with and without pasteurisation at $70{ }^{\circ} \mathrm{C}$ for 30 min followed by cooling the samples to room temperature (c.a. $20^{\circ} \mathrm{C}$ ) in an ice bath before any further handling. A natural bacterial inoculum of CTW collected during each sampling campaign was added to all water samples whether pasteurised or not to ensure the presence of a broad bacterial community. The final concentration of inoculum in samples was $\sim 10 \times 10^{3}$ ICC $/ \mathrm{mL}$ as suggested elsewhere (Hammes and Egli, 2005; Farhat et al., 2018). The added volume of CTW for inoculation was determined by its initial cell count (measured by FCM), and it was around $18 \pm 2 \mu \mathrm{L} / \mathrm{mL}(\sim 1.75 \% \mathrm{v} / \mathrm{v})$ throughout the study period. Due to inoculation, trace elements present in CTW were added to the lab-Remin blank as shown in Table 2.3. No further amendments have been performed on the practical samples (CTW and site-Remin) to measure their actual BGP, whereas $\mathrm{P}$ and $\mathrm{N}$ have been added to the blanks (as described in the following sections). Routinely, addition of the different chemicals and inoculum was done using pipettes with sterilised plastic tips which were rinsed 10 times with ultra-pure water before using to avoid AOC leaching into the water samples. 
Further developing the bacterial growth potential method for ultra-pure drinking water produced by remineralisation of reverse osmosis permeate

Table 2.3. Concentration of trace elements added to lab-Remin (lab-remineralised RO permeate) as a result of inoculating with CTW (conventionally treated water.

\begin{tabular}{lll}
\hline Element & Unit & $\begin{array}{l}\text { Concentration in } \\
\text { lab-Remin }\end{array}$ \\
\hline Phosphate & $\mu \mathrm{g} / \mathrm{L} \mathrm{PO}_{4}-\mathrm{P}$ & 0.15 \\
Hydrogen carbonate & $\mathrm{mg} / \mathrm{L} \mathrm{HCO}^{-}$ & 4.05 \\
Calcium & $\mathrm{mg} / \mathrm{L} \mathrm{Ca}^{2+}$ & 0.42 \\
Magnesium & $\mathrm{mg} / \mathrm{L} \mathrm{Mg}^{2+}$ & 0.29 \\
Sodium & $\mathrm{mg} / \mathrm{L} \mathrm{Na}^{+}$ & 1.87 \\
Potassium & $\mathrm{mg} / \mathrm{L} \mathrm{K}^{+}$ & 0.08 \\
Iron & $\mu \mathrm{g} / \mathrm{L} \mathrm{Fe}^{2+}$ & 0.15 \\
Manganese & $\mu \mathrm{g} / \mathrm{L} \mathrm{Mn}^{2+}$ & 0.09 \\
Aluminium & $\mu \mathrm{g} / \mathrm{L} \mathrm{Al}^{3+}$ & 0.07 \\
Copper & $\mu \mathrm{g} / \mathrm{L} \mathrm{Cu}^{2+}$ & 0.01 \\
Lead & $\mu \mathrm{g} / \mathrm{L} \mathrm{Pb}^{2+}$ & 0.01 \\
Chromium & $\mu \mathrm{g} / \mathrm{L} \mathrm{Cr}^{2+}$ & 0.01 \\
Zinc & $\mu \mathrm{g} / \mathrm{L} \mathrm{Zn}^{2+}$ & 0.01 \\
Ammonium & $\mu \mathrm{g} / \mathrm{L} \mathrm{NH}_{4}{ }^{+}$ & 0.17 \\
Nitrate & $\mu \mathrm{g} / \mathrm{L} \mathrm{N}^{-}$ & 0.05 \\
Chloride & $\mathrm{mg} / \mathrm{L} \mathrm{Cl}^{-}$ & 1.37 \\
Sulphate & $\mathrm{mg} / \mathrm{L} \mathrm{SO}_{4}{ }^{2-}$ & 0.93 \\
Fluoride & $\mu \mathrm{g} / \mathrm{L} \mathrm{F}^{-}$ & 1.66 \\
\hline
\end{tabular}

Test procedures: After performing the aforementioned adjustments, each water sample was transferred into three AOC-free glass vials by direct pouring of $20 \pm 2 \mathrm{~mL}$ per vial (volume was measured using a reference vial). The glass vials containing the samples were incubated at $30{ }^{\circ} \mathrm{C}$ in the dark under static conditions. Aliquots were poured from the incubated vials into $1.5 \mathrm{~mL}$ Eppendorf tubes to perform FCM analysis on day 0 (initial count), 1, 3, 6, 8, $10,13,16$, and 20. BGP was expressed as the maximum count obtained during the 20-day incubation period.

Flow cytometry (FCM) measurement: Flow cytometry (FCM) coupled with fluorescence staining has been selected for this study to quantify cell counts in water samples. The FCM (BD Accuri $\mathrm{C}^{\circledR}{ }^{\circledR} \mathrm{FCM}$, Belgium) is fitted with a $50 \mathrm{~mW}$ laser with emission wavelength of $488 \mathrm{~nm}$, green fluorescence intensity detector (FL1 channel, $533 \pm 30 \mathrm{~nm}$ ), red fluorescence intensity detector (FL3 channel, $>670 \mathrm{~nm}$ ), and sideward and forward scattered light intensity collectors. The staining protocol described by Prest et al. (2013) was applied during this study where two staining solutions were prepared: (i) SYBR ${ }^{\circledR}$ Green I (SG) 1:100 diluted in filtered (IC Millex - LG, $0.2 \mu \mathrm{m}$, Millipore) DMSO for total cell count (TCC), and (ii) a mix of $\mathrm{SYBR}^{\circledR}$ Green I and propidium iodide (SGPI) with a PI working concentration of $0.3 \mathrm{mM}$ and 1:100 diluted SG in filtered DMSO for intact cell count (ICC). 
Further developing the bacterial growth potential method for ultra-pure drinking water produced by remineralisation of reverse osmosis permeate

The staining protocol includes preheating of $500 \mu \mathrm{L}$ of sample to $35 \pm 2{ }^{\circ} \mathrm{C}$ for $5 \mathrm{~min}$, staining either with SG or SGPI $(10 \mu \mathrm{L} / \mathrm{mL})$ depending on the desired measurement, incubating in the dark at $35 \pm 2{ }^{\circ} \mathrm{C}$ for $10 \mathrm{~min}$, and lastly measuring with $\mathrm{FCM}$ at $35 \mu \mathrm{L} / \mathrm{min}$ flow rate and $50 \mu \mathrm{L}$ of analysed sample volume (identical settings to volumetric calibration of FCM) with setting a threshold on FL1 channel of green fluorescence to 700. Data acquisition was performed using BD Accuri $\mathrm{CFlow}^{\circledR}$ software where a digital gate was set on FL1/FL3 density plot to distinguish the stained bacterial cells from inorganic particles of water samples and instrument noise. The FCM detection limit is $10^{3}$ cells $/ \mathrm{mL}$. Samples were diluted when bacterial counts exceeded $200 \times 10^{3}$ cells $/ \mathrm{mL}$.

\subsubsection{Statistical analysis}

Different statistical tools were applied using the Microsoft Excel software, including: (i) QQ plots, Chi-squared tests, and Kolmogorov-Smirnov tests to check the normality of data, and (ii) Student's $t$-test and one-way analysis of variance (ANOVA) to determine the significance of differences. Simple linear regression analysis was conducted for quantitative correlation between two variables. A confidence level of 95\% was considered (alpha of $0.05)$.

\subsection{Results}

\subsubsection{Laboratory remineralised RO permeate (lab-Remin) as an ultra-pure blank for the bacterial growth potential (BGP)}

As shown in Figure 2.2, the BGP of conventional blanks expressed as absolute maximum growth obtained during a 20-day period of incubation was in $80 \times 10^{3}-220 \times 10^{3} \mathrm{ICC} / \mathrm{mL}$ for bottled Evian water (BEW), $100 \times 10^{3}-210 \times 10^{3} \mathrm{ICC} / \mathrm{mL}$ for deep groundwater (DGW) treated by aeration, and $375 \times 10^{3}-500 \times 10^{3} \mathrm{ICC} / \mathrm{mL}$ for slow sand filtrate (SSF). Regarding site samples, conventionally treated groundwater (CTW) had an average BGP of $630 \pm 70 \times 10^{3} \mathrm{ICC} / \mathrm{mL}$, whereas the BGP of RO-treated water after post-treatment (siteRemin) was considerably reduced (by $85 \%$ ) to $90 \pm 20 \times 10^{3} \mathrm{ICC} / \mathrm{mL}$, which can no longer be affirmed by the BGP detection limit using conventional blanks. Noteworthy, laboratory remineralised RO permeate (lab-Remin) had a BGP of $50 \pm 20 \times 10^{3} \mathrm{ICC} / \mathrm{mL}$, which is significantly lower than that of conventional blanks and site-Remin $(P<0.05)$.

Furthermore, the lab-Remin blank showed better reproducibility where the standard deviation $\left(\sim 20 \times 10^{3} \mathrm{ICC} / \mathrm{mL}\right)$ was significantly lower than that observed for the conventional blanks $\left(>50 \times 10^{3} \mathrm{ICC} / \mathrm{mL}\right)$. This observation can also be confirmed by the constant initial cell count of the lab-Remin blank $\left(\sim 2 \times 10^{3} \mathrm{ICC} / \mathrm{mL}\right)$ measured on different dates, whereas up to $40 \%$ variation was observed for conventional blanks $\left(\sim 60 \times 10^{3}-80 \times\right.$ $10^{3} \mathrm{ICC} / \mathrm{mL}$ in average, as shown in Figure 2.3). 
Further developing the bacterial growth potential method for ultra-pure drinking water produced by remineralisation of reverse osmosis permeate

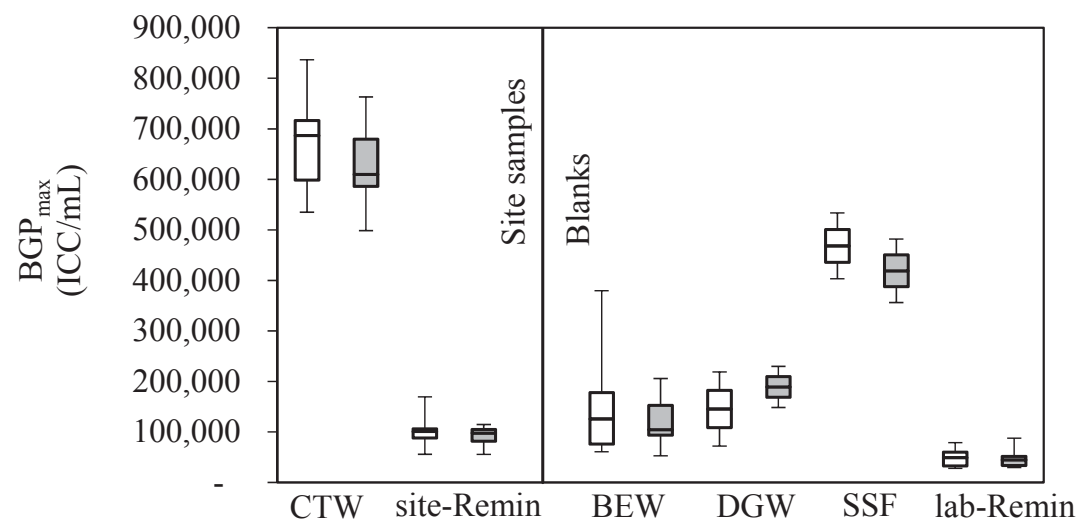

Figure 2.2. BGP of non-pasteurised ( $\square$ ) and pasteurised ( $\square$ ) water samples: CTW (conventionally treated groundwater, $n=16$ ), site-Remin (post-treated RO permeate at the site, $n=13$ ), BEW (bottled Evian water, $n=7$ ), DGW (deep groundwater treated by aeration, $\mathrm{n}=2$ ), SSF (slow sand filtrate of surface water supply, $\mathbf{n}=2$ ), and lab-Remin (labremineralized RO permeate, $n=19$ ). Each sample was inoculated with CTW. BGP is expressed as the maximum bacterial growth during an incubation period of 20 days at $30^{\circ} \mathrm{C}$. Error bars represent the measurement variations of " $n$ " separate tests, with triplicate vials per test.

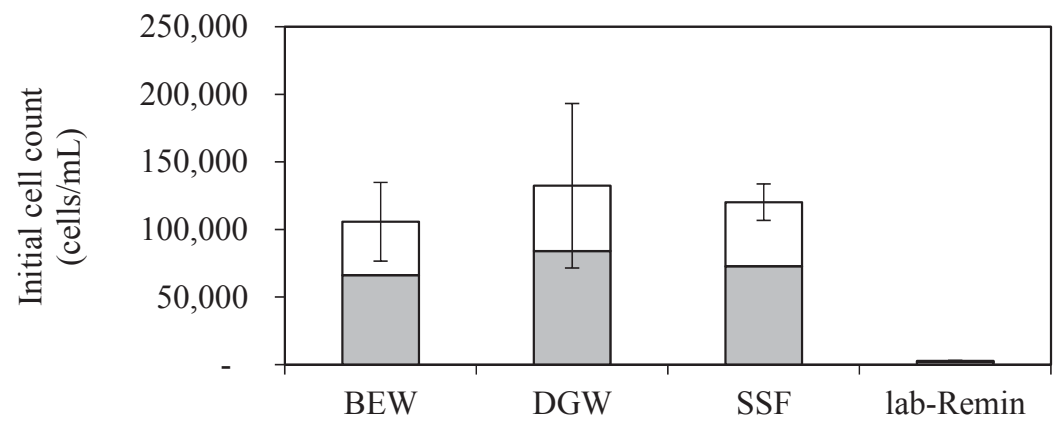

Figure 2.3. Initial intact ( $\square$ ), dead ( $\square$ ), and total ( $\square+\square$ ) cell count of the blanks: BEW $(n=7)$, DGW $(n=2), \operatorname{SSF}(n=2)$, and lab-Remin $(n=19)$ as measured by FCM. Error bars represent the measurement variations of " $n$ " tests, in triplicate each. 
Further developing the bacterial growth potential method for ultra-pure drinking water produced by remineralisation of reverse osmosis permeate

\subsubsection{Influence of chemical addition and inoculation on BGP of lab-Remin blank}

The chemical stocks used to adjust $\mathrm{pH}$ and mineral content of $\mathrm{RO}$ permeate contain impurities which can be biodegradable and lead to increase the BGP of lab-Remin blank. However, the results showed that the added volumes of $\mathrm{NaHCO}_{3}$ stock solution to obtain final concentrations of $61,122,183$, and $244 \mathrm{mg} / \mathrm{L} \mathrm{HCO}_{3}{ }^{-}$(final $\mathrm{pH}$ of $7.8 \pm 0.2$ in all cases) led to insignificantly different $(P>0.05)$ BGP of lab-Remin blank (Figure 2.4).

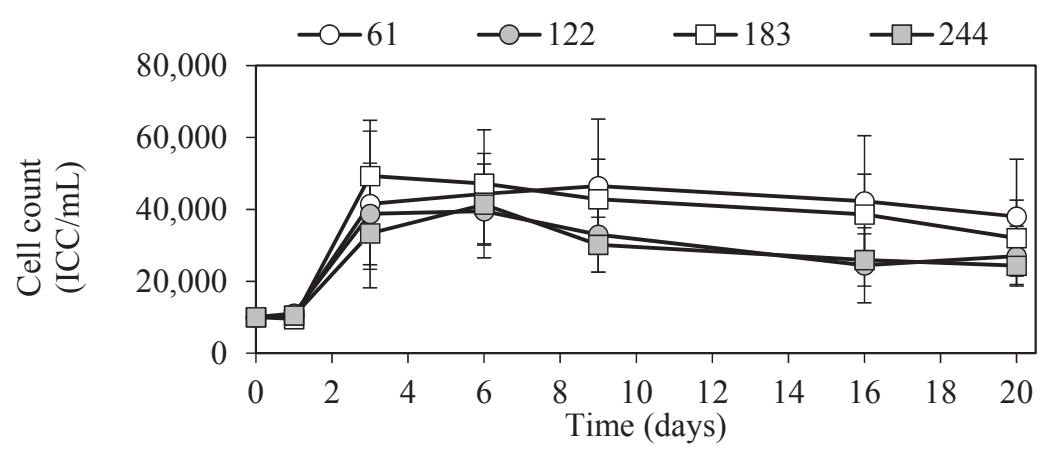

Figure 2.4. Bacterial growth in inoculated lab-Remin blank after adjustment of $\mathrm{pH}$ to $7.8 \pm 0.2$ with different concentrations of $\mathrm{NaHCO}_{3}$ (in $\mathrm{mg} / \mathrm{L} \mathrm{HCO}_{3}{ }^{-}$). Error bars represent the measurement variations of triplicate vials.

Introduction of biodegradable compounds can also occur when inoculating the lab-Remin blank with natural bacteria of fresh CTW, which may lead to additional BGP. Theoretically, this additional BGP depends on inoculum volume and can be calculated (see section 2.2.3) as shown in Table $2.4(\triangle \mathrm{BGP}$ consortium) for several inoculum concentrations (namely: $0.5 \times$ $10^{3}, 1 \times 10^{3}, 2 \times 10^{3}, 5 \times 10^{3}, 10 \times 10^{3}, 20 \times 10^{3}$, and $50 \times 10^{3} \mathrm{ICC} / \mathrm{mL}$ corresponding to inoculum volume). The final inoculum concentration selected for this study is $10 \times 10^{3}$ ICC/mL as suggested elsewhere (Hammes and Egli, 2005; Farhat et al., 2018) to ensure the presence of sufficient cells to initiate growth. The theoretical increase in BGP due to the selected inoculum concentration, compared with non-inoculated lab-Remin blank, was in the range of $11 \times 10^{3}-14 \times 10^{3} \mathrm{ICC} / \mathrm{mL}$ (Table 2.4), which was also observed experimentally with a high significance level $(P<0.05)$ by conducting a large number of tests $(\mathrm{n}=18$ tests in triplicate, Figure $2.5 \mathrm{~B})$. However, this increase was experimentally insignificant $(P>0.05)$ with a small number of tests $(n=1$ test in triplicate, Figure $2.5 \mathrm{~A})$. 
Further developing the bacterial growth potential method for ultra-pure drinking water produced by remineralisation of reverse osmosis permeate

Table 2.4. The theoretical ( $\triangle \mathrm{BGP}$ consortium) and experimental increase in the BGP of lab-Remin blank due to inoculation.

\begin{tabular}{llll}
\hline $\begin{array}{l}\text { Inoculum } \\
\text { concentration } \\
\left(\times \mathbf{1 0}^{\mathbf{3}} \mathbf{I C C} / \mathbf{m L}\right)\end{array}$ & $\begin{array}{l}\Delta \mathbf{B G P}_{\text {consortium }} \\
\left(\times \mathbf{1 0}^{\mathbf{3}} \mathbf{I C C} / \mathbf{m L}\right)\end{array}$ & $\begin{array}{l}\text { Experimental increase } \\
\text { in } \mathbf{B G P} \\
\left(\times \mathbf{1 0}^{\mathbf{3}} \mathbf{I C C} / \mathbf{m L}\right)\end{array}$ & $\boldsymbol{P}$-value $^{\mathbf{b}}$ \\
\hline 0.5 & & 14 & \\
1 & $\sim 0.5$ & 23 & 0.1530 \\
2 & $\sim 1$ & 3 & 0.0643 \\
5 & $2-3$ & 6 & 0.4017 \\
10 & $6-7$ & 17 & 0.3222 \\
20 & $11-14$ & 19 & 0.2108 \\
50 & $22-27$ & 80 & 0.0914 \\
\hline
\end{tabular}

${ }^{a}$ BGP Increase compared with non-inoculated lab-Remin (calculated based onFigure 2.5 Figure $2.5 \mathrm{~A})$

${ }^{\mathrm{b}}$ significant experimental increase if $P$-value $<0.05$
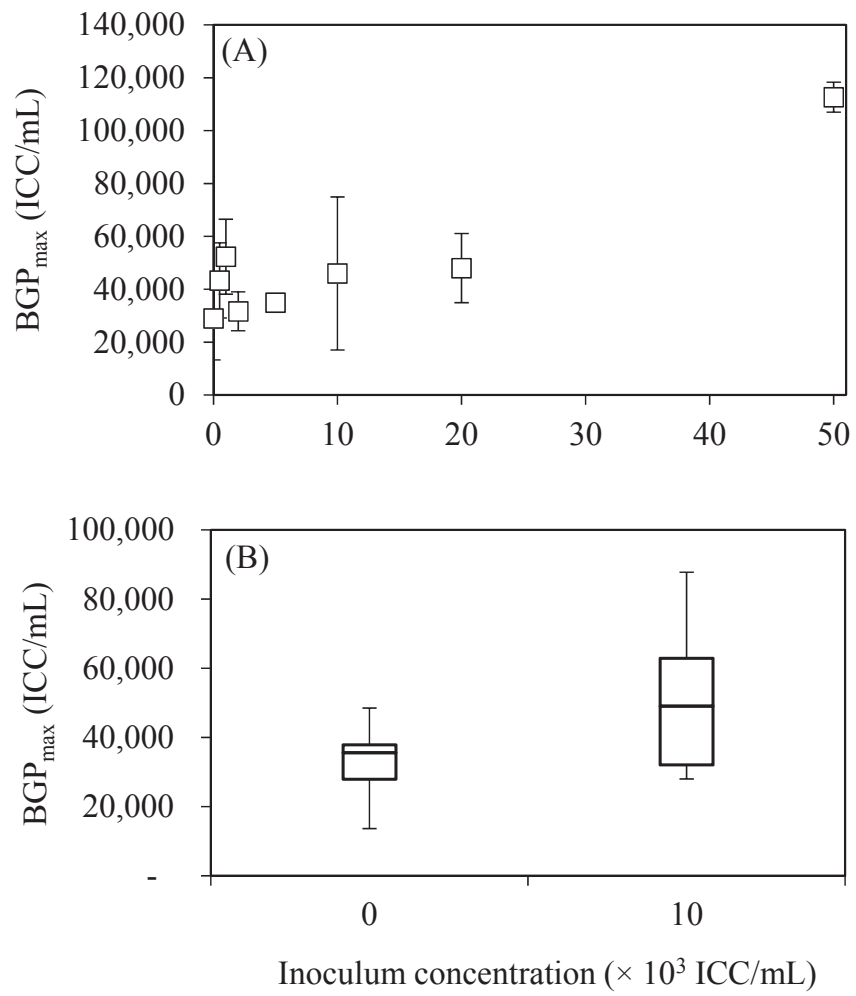

Figure 2.5. BGP of the lab-Remin blank (laboratory remineralized RO permeate) with different concentrations of CTW inoculum $(n=1, A)$, and $10 \times 10^{3} \mathrm{ICC} / \mathrm{mL}$ concentration of CTW inoculum $(n=18, B)$ compared with non-inoculated blank. The BGP was expressed as the maximum bacterial growth during an incubation period of 20 days at $30{ }^{\circ} \mathrm{C}$. Error bars represent the measurement variations of " $n$ " separate tests, with triplicate vials per test. 
Further developing the bacterial growth potential method for ultra-pure drinking water produced by remineralisation of reverse osmosis permeate

Although the increase in BGP due to inoculation can be theoretically reduced by decreasing the inoculum concentration to $5 \times 10^{3} \mathrm{ICC} / \mathrm{mL}$ or even lower (Table 2.4), still a larger number of BGP tests ( $\mathrm{n}>150$ tests in triplicate, based on student's $t$-test calculations) will be needed to detect this increase experimentally, which is beyond the scope of this study. As a result, the BGP of lab-Remin blank without and with inoculation with the selected concentration $\left(10 \times 10^{3} \mathrm{ICC} / \mathrm{mL}\right)$ was $35 \pm 10 \times 10^{3}$ and $50 \pm 20 \times 10^{3} \mathrm{ICC} / \mathrm{mL}$, respectively. Therefore, contribution of inoculum to the measured BGP of lab-Remin blank is about 20 $30 \%$.

The large number of BGP tests needed is attributed to the higher standard deviation of BGP measurements $\left(\sim 20 \times 10^{3} \mathrm{ICC} / \mathrm{mL}\right)$ compared with the target theoretical increase in BGP. For instance, the measured increase in BGP due to inoculating with $50 \times 10^{3} \mathrm{ICC} / \mathrm{mL}(\sim 80$ $\left.\times 10^{3} \mathrm{ICC} / \mathrm{mL}\right)$ was according to the theoretical calculations $\left(58 \times 10^{3}-70 \times 10^{3} \mathrm{ICC} / \mathrm{mL}\right.$ $>$ standard deviation of BGP measurements), as shown in Table 2.4 , even with a small number of tests ( $\mathrm{n}=1$ test in triplicate, Figure $2.5 \mathrm{~A})$.

\subsubsection{Effect of initial cell count on the BGP: Is there a need for pasteurisation?}

The typical shape of bacterial growth curves was not observed when the initial cell count is higher than the maximum bacterial growth that can be maintained by nutrients in water. This effect was occasionally observed for non-pasteurised site-Remin samples (Figure 2.6A) where the initial cell count of non-pasteurised samples $\left(\mathrm{C}_{0}\right.$, non-pasteurised $\left.=170 \times 10^{3} \mathrm{ICC} / \mathrm{mL}\right)$ was substantially higher than the maximum bacterial growth that could be maintained by the nutrients available for bacteria $\left(\mathrm{C}_{\max }=110 \times 10^{3} \mathrm{ICC} / \mathrm{mL}\right)$, and thus, bacterial counts decreased immediately after incubation. This was observed when fresh calcite grains were used in the remineralisation step and the attached bacteria may have washed-out.

Table 2.5. Bacterial growth parameters of non-pasteurised and pasteurised site-Remin samples under different operating conditions.

\begin{tabular}{|c|c|c|c|c|}
\hline \multirow[t]{2}{*}{ Case $^{a}$} & \multicolumn{3}{|c|}{ Cell count $\left(\times 10^{3} \mathrm{ICC} / \mathrm{mL}\right)$} & \multirow{2}{*}{$\begin{array}{l}\text { Specific growth rate, } \\
\mu \text { (/day) }\end{array}$} \\
\hline & Initial & Maximum & Net growth ${ }^{b}$ & \\
\hline Case A: non-pasteurised & 170 & 170 & 0 & n.a. ${ }^{\mathrm{c}}$ \\
\hline Case A: pasteurised & 20 & 115 & 95 & 0.49 \\
\hline Case B: non-pasteurised & 22 & 96 & 74 & 0.74 \\
\hline Case B: pasteurised & 10 & 98 & 88 & 0.85 \\
\hline
\end{tabular}

Unlike the non-pasteurised samples, pasteurised site-Remin samples resulted in the typical bacterial growth curves where growth parameters could be calculated (Table 2.5). In 
Further developing the bacterial growth potential method for ultra-pure drinking water produced by remineralisation of reverse osmosis permeate

contrast to the previous case, non-pasteurised as well as pasteurised site-Remin samples resulted in the typical bacterial growth curves when the calcite filter was in operation for several weeks (Figure 2.6B), and the bacterial growth parameters could be calculated for both water samples (Table 2.5). In this case, the maximum growth level for both nonpasteurised and pasteurised samples was identical $\left(\mathrm{C}_{\max }=\sim 98 \times 10^{3} \mathrm{ICC} / \mathrm{mL}\right)$ regardless of the difference in the initial cell count.
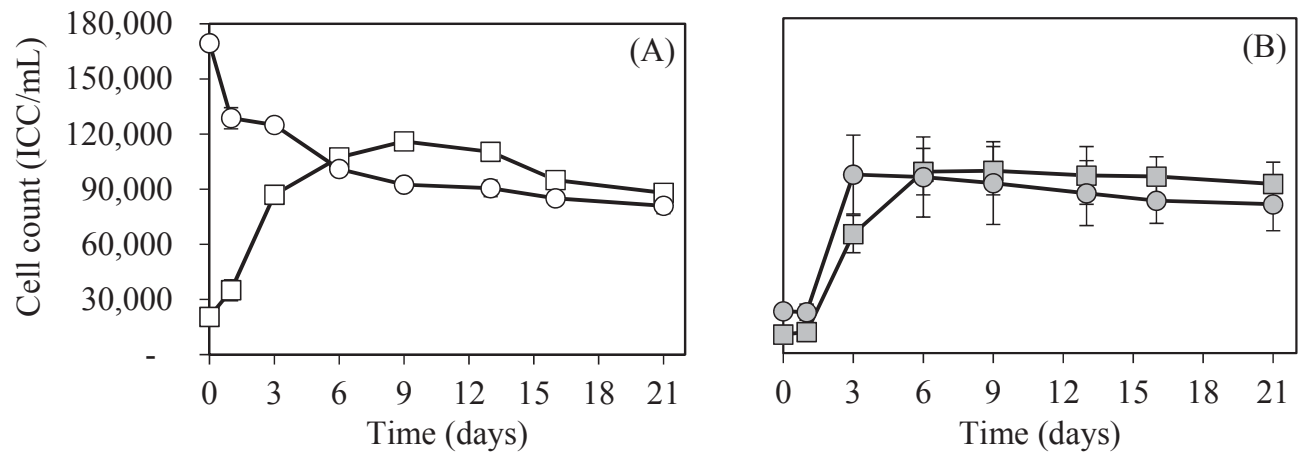

Figure 2.6. Examples of bacterial growth curves in pasteurised (squares) and non-pasteurised (circles) site-Remin samples analysed on two different dates: with fresh calcite grains $\left(\mathrm{C}_{0}\right.$ for non-pasteurised $\left.>C_{\max }, A\right)$, and when the calcite contactors have been in operation for several weeks $\left(C_{0}\right.$ for non-pasteurised $<C_{\max }$, B). Each sample was inoculated with $C T W$. Error bars represent the measurement variations of triplicate vials.

\subsubsection{Case study: monitoring BGP of drinking water produced by $R O$ and post-treatment (site-Remin)}

Figure 2.7 shows the BGP results of pasteurised and inoculated (with $10 \times 10^{3} \mathrm{ICC} / \mathrm{mL}$ of the original water and $\mathrm{CTW}$ ) site-Remin samples at different time intervals after refilling the calcite contactors with fresh calcite grains. BGP decreased dramatically from $\sim 470 \times$ $10^{3} \mathrm{ICC} / \mathrm{mL}$ for the sample collected immediately after starting the operation with the fresh calcite grains to a stable level of $80 \times 10^{3}-110 \times 10^{3} \mathrm{ICC} / \mathrm{mL}$ after $3 \mathrm{~h}$ of operation. Similar trends were observed for the dissolved organic carbon (DOC) and initial cell count of nonpasteurised samples. The DOC concentration and initial cell count decreased from 3.1 to $<0.3 \mathrm{mg} / \mathrm{L}$ and from $280 \times 10^{3}$ to $20 \times 10^{3} \mathrm{ICC} / \mathrm{mL}$ over time, respectively (Figure 2.8).

For this monitoring test, lab-Remin blanks were measured on each sampling day and the average resulting BGP was $\sim 50 \times 10^{3} \mathrm{ICC} / \mathrm{mL}$, which was significantly $(P<0.05)$ lower than the BGP of site-Remin samples after reaching stability $\left(80 \times 10^{3}-110 \times 10^{3} \mathrm{ICC} / \mathrm{mL}\right)$. 
Further developing the bacterial growth potential method for ultra-pure drinking water produced by remineralisation of reverse osmosis permeate

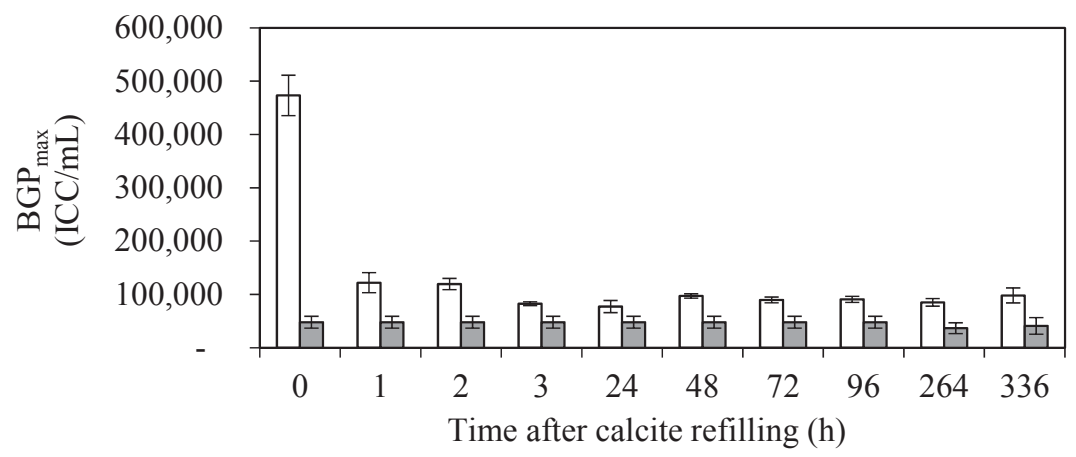

Figure 2.7. BGP of pasteurised and inoculated lab-Remin blanks (laboratory remineralised RO permeate, $\square$ ) and site-Remin (post-treated RO permeate at the site, $\square$ ) collected at different time intervals after refilling the calcite contactors with fresh calcite grains $(n=3)$. Each sample was inoculated with CTW. The BGP was expressed as the maximum bacterial growth during an incubation period of 20 days at $30^{\circ} \mathrm{C}$. Error bars represent the measurement variations of triplicate measurements.

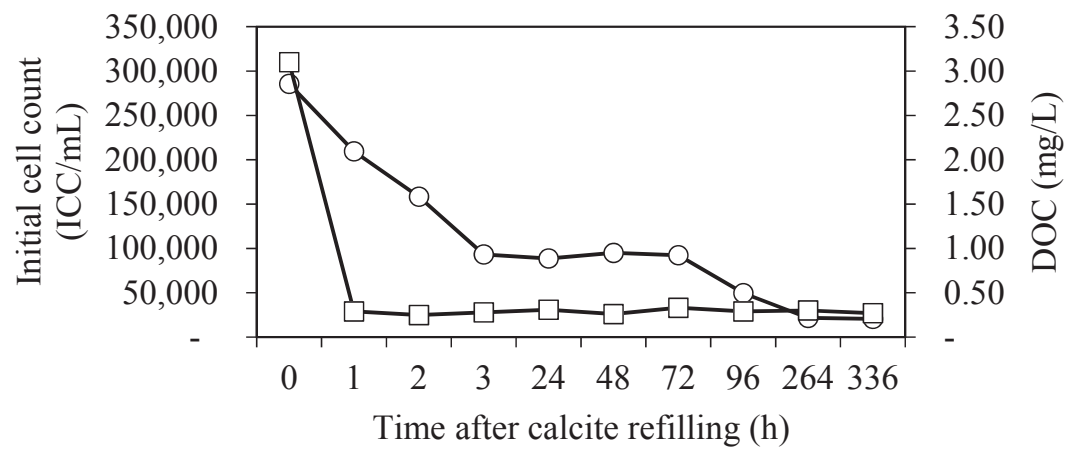

Figure 2.8. DOC ( $\square-$ ) and initial cell count ( $-\circ-$ ) of non-pasteurised site-Remin samples (post-treated RO permeate at the site) collected at different time intervals after refilling the calcite contactors with fresh calcite grains $(n=3)$. 
Further developing the bacterial growth potential method for ultra-pure drinking water

produced by remineralisation of reverse osmosis permeate

\subsection{Discussion}

\subsubsection{Composition of the ultra-pure lab-Remin blank and factors influencing the BGP measurements at a low nutrient level}

It is proposed to use a lab-Remin blank (which is RO permeate after remineralisation in the laboratory to adjust $\mathrm{pH}$ to $7.8 \pm 0.2$ and mineral content) as an ultra-pure blank for BGP measurements of very low nutrient drinking water produced by desalination technologies. The adjustments of the lab-Remin blank and the addition of phosphate and nitrogen ensure that bacterial growth is limited by carbon. The $\mathrm{pH}$ adjustment of the lab-Remin blank is necessary since low $\mathrm{pH}$ may hinder the ability of bacteria to effectively hydrolyse nutrients (Russell and Wilson, 1996), and it requires complex adaptive strategies to maintain a neutral intracellular $\mathrm{pH}$ (Dilworth and Glenn, 1999). This was confirmed by the observation of no significant growth with the original $\mathrm{pH}$ (5.5) of $\mathrm{RO}$ permeate in the present study (data not shown). These results might explain the very low bacterial yield observed in the study of Elhadidy et al. (2016) for synthetic water comprising Milli-Q water, nitrogen, phosphate, and carbon (acetate) without $\mathrm{pH}$ adjustment. Besides, mineral addition is essential because the low ionic strength of RO permeate may cause osmotic shock in aquatic microorganisms (Kaplan et al., 1993).

The BGP of lab-Remin might also be limited by the absence of trace elements required for bacterial growth, such as iron and manganese (Durand and Kawashima, 1980; Takashima et al., 1990). In this regard, it is assumed that the minimum required concentrations of such elements are added to lab-Remin when inoculating with CTW which contains sufficient amounts of these elements (Table 2.3). This was confirmed by the observation of no additional growth in the inoculated lab-Remin blank when a trace elements broth (Fe, $\mathrm{Zn}$, B and Co up to $200 \mu \mathrm{g} / \mathrm{L}$ ) was added (data not shown). Additionally, Church et al. (2000) also found that $\mathrm{Fe}$ concentration similar to that available in the lab-Remin blank after inoculation $(0.15 \mu \mathrm{g} / \mathrm{L} \mathrm{Fe}$, Table 2.3) is sufficient for bacterial growth. All the aforementioned adjustments, together with the addition of phosphate and nitrogen, guarantee that the BGP of lab-Remin $\left(50 \pm 20 \times 10^{3} \mathrm{ICC} / \mathrm{mL}\right)$ is limited by organic carbon rather than the inorganic constituents. Therefore, any potential carbon contamination that may significantly influence the low levels of BGP can be detected.

The addition of chemicals to adjust water quality of RO permeate is a source of contamination, where even using reagent grade chemical stock solutions ( $>99 \%$ purity) may cause unwanted addition of nutrients that could increase the BGP of lab-Remin blank. It is ideal to use AOC-free chemical stock solutions for necessary water quality adjustments. However, they are commercially not available (Kaplan et al., 1993), because chemical manufacturing for laboratory and commercial purposes involves the usage of additives and impurities (Patnaik, 2003). Nonetheless, the results revealed that there was no significant effect of $\mathrm{NaHCO}_{3}$ chemical impurities (>99.5\% purity) on the BGP of lab-Remin blank. 
Further developing the bacterial growth potential method for ultra-pure drinking water produced by remineralisation of reverse osmosis permeate

Therefore, other chemical stocks (i.e., reagent grade $\mathrm{CaCl}_{2}$ and $\mathrm{MgCl}_{2},>99 \%$ purity) are assumed to have insignificant effects as well, since their final concentration $(\sim 145 \mathrm{mg} / \mathrm{L}$ $\mathrm{CaCl}_{2} \cdot 2 \mathrm{H}_{2} \mathrm{O}$ and $\left.35 \mathrm{mg} / \mathrm{L} \mathrm{MgCl} \cdot 6 \mathrm{H}_{2} \mathrm{O}\right)$ in the lab-Remin blank was lower than that of $\mathrm{NaHCO}_{3}(\sim 170 \mathrm{mg} / \mathrm{L} \mathrm{NaHCO} 3)$.

Although RO permeate should be totally bacteria-free due to the smaller pore size of RO membranes $(<1 \mathrm{~nm})$ compared with bacterial cells (typically $>200 \mathrm{~nm}$ ), it still contains bacteria that are able to grow and reproduce. This is a common observation in several RO studies (Park and Hu, 2010; Dixon et al., 2012; Fujioka et al., 2018). The practical aspects, such as leakage in membrane systems (e.g., O-rings of interconnectors) (Liu et al., 2013a; Pype et al., 2016) or bacterial growth in the permeate side, are possible reasons for this observation. Despite the bacterial content of RO permeate, fresh bacterial inoculum of CTW was always added to the lab-Remin blank to ensure the presence of a broad bacterial community in addition to its original cell load. As a result of using fresh CTW for inoculation, unwanted increase in nutrient content of the lab-Remin blank could occur. The consistent and simple approach in this study of inoculating with fresh CTW ensures the viability and activity of cells, even though protocols to prepare AOC-free natural bacterial inoculum are suggested (Hammes and Egli, 2005). The additional BGP of lab-Remin blank caused by increase in nutrients due to inoculation could be quantified ( $\triangle \mathrm{BGP}_{\text {consortium, }}$, Table $2.4)$ as the characteristics of the inoculum are known. Therefore, the measured BGP of labRemin blank can be corrected where the actual BGP can be expressed as BGPactual $=$

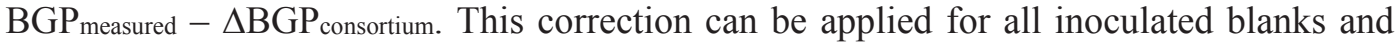
samples but it will be more critical in the case of ultra-low-nutrient water such as the labRemin blank, where $\triangle \mathrm{BGP}_{\text {consortium }}$ can reach $30 \%$ of the measured BGP when inoculating with $10 \times 10^{3} \mathrm{ICC} / \mathrm{mL}$ of $\mathrm{CTW}$, and the site-Remin samples, where this percentage decreases to $10-15 \%$. However, this additional BGP is insignificant for CTW samples (less than $2 \%$ ). In this study, no correction was made because all the blanks and samples were inoculated with the same concentration of CTW bacteria $\left(10 \times 10^{3} \mathrm{ICC} / \mathrm{mL}\right)$, and hence, the absolute differences will remain unchanged with and without correction.

Interestingly, the results (Table 2.4) showed that the increase in BGP of the lab-Remin blank after inoculation is solely attributed to nutrient content of CTW inoculum. This suggests that the indigenous bacteria in RO permeate are capable of utilising all the nutrients available in the lab-Remin blank, and thus, the BGP of the non-inoculated lab-Remin blank reflects the total nutrient content of the RO permeate. However, we argue here to inoculate the lab-Remin blank in all cases (for any future study) before measuring BGP to ensure no growth limitation occurs because of the limited diversity of the bacterial strains in RO permeate. 
Further developing the bacterial growth potential method for ultra-pure drinking water produced by remineralisation of reverse osmosis permeate

\subsubsection{Comparing the ultra-pure lab-Remin blank with conventional blanks}

In the present study, the detection limit of the BGP method was further decreased to $50 \pm 20 \times 10^{3} \mathrm{ICC} / \mathrm{mL}$ after using the ultra-pure lab-Remin blank compared with conventional blanks, namely: bottled Evian water (BEW), deep groundwater (DGW) treated by aeration, and slow sand filtrate (SSF) of surface water supply, which have BGP ranging from $100 \times 10^{3}-600 \times 10^{3} \mathrm{ICC} / \mathrm{mL}$, as reported elsewhere (Vital et al., 2007; BucheliWitschel et al., 2012; Bereschenko and Hornstra, 2014; Guo et al., 2014; Mikkers and Magic-Knezev, 2014; van der Kooij et al., 2014; Prest et al., 2016a) and affirmed in this study.

The lower BGP of the lab-Remin blank compared with conventional blanks was found whether pasteurisation was applied before measuring BGP or not. This observation can be explained by the lower organic nutrient content (DOC) of the lab-Remin blank ( $<0.3 \mathrm{mg} / \mathrm{L}$, detection limit) compared with the conventional blanks $(\sim 0.5 \mathrm{mg} / \mathrm{L})$. Furthermore, the measured BGP of the lab-Remin blank with flow cytometry can be expressed as AOC concentration using the reported yield factor of $1 \times 10^{7}$ cells $/ \mu \mathrm{g}$ Ac-C (Hammes and Egli, 2005; Prest et al., 2016a). The estimated AOC concentration of the lab-Remin blank is $5 \pm 2 \mu \mathrm{g} / \mathrm{L}$ Ac-C and is lower than the reported AOC content of BEW $(10-52 \mu \mathrm{g} / \mathrm{L} \mathrm{Ac}-\mathrm{C}$ (Vital et al., 2007; Bucheli-Witschel et al., 2012)) measured using a natural bacterial consortium according to Hammes and Egli (2005). However, the estimated AOC concentration of the lab-Remin blank is slightly higher than that of DGW and SSF (1-4 $\mu \mathrm{g} / \mathrm{L}$ Ac-C (Bereschenko and Hornstra, 2014; van der Kooij et al., 2014)) measured using pure bacterial strains (P17 and NOX) according to van der Kooij et al. (1982). The latter appears to contradict the BGP results obtained in this study where the lab-Remin blank was found to support much lower bacterial growth than DGW and SSF. The reason is that the AOC measuring protocol has a pronounced effect on the obtained concentrations, as previously highlighted (Ross et al., 2013). The critical methodological aspects are the pretreatment of water samples and the inoculum type, where the pure bacterial stains (P17 and NOX) are known to lead to lower AOC content compared with the natural bacterial communities (Hammes and Egli, 2005). However, the estimated AOC content of BEW, DGW and SSF, using the measured BGP in the present study and the yield factor of $1 \times 10^{7} \mathrm{cells} / \mu \mathrm{g} \mathrm{Ac-C}$ (Hammes and Egli, 2005; Prest et al., 2016a), is in the range of 10$60 \mu \mathrm{g} / \mathrm{L} \mathrm{Ac-C}$ and is significantly higher than that of the lab-Remin blank.

Another advantage of the lab-Remin blank over the conventional blanks is the high reproducibility. The results show that the lab-Remin blank is more reproducible (standard deviation of $\sim 20 \times 10^{3} \mathrm{ICC} / \mathrm{mL}$ ) compared with BEW, DGW and SSF (standard deviation of $>50 \times 10^{3} \mathrm{ICC} / \mathrm{mL}$ ). The reproducibility of the lab-Remin blank can be attributed to high nutrient removal efficiency and constant performance of RO treatment regardless of feed water quality and environmental factors (Escobar et al., 2000; Hong et al., 2005; Park and 
Further developing the bacterial growth potential method for ultra-pure drinking water produced by remineralisation of reverse osmosis permeate

Hu, 2010; Thayanukul et al., 2013). For conventional blanks, they are prone to water quality changes influenced by operating conditions, for instance, switching extraction wells in the case of groundwater and fluctuating treatment efficiency. This explanation can be confirmed by the lower variation in the measured initial cell count of RO permeate compared with that of conventional blanks (up to 40\%). The higher reproducibility of the lab-Remin blank implies that any contamination during BGP measurements could be detected more easily compared with conventional blanks.

Although the BGP of lab-Remin blank might be overestimated due to the addition of phosphate and nitrogen, it is still lower than the actual BGP of ultra-pure drinking water produced by RO and post-treatment including remineralization (site-Remin) measured without any amendments. Using a lab-Remin blank, the BGP of the site-Remin samples could be reliably measured and was considerably lower (85\%) than that of conventionally treated water from the same groundwater source. The difference in BGP observed between the remineralized RO permeate under controlled conditions (lab-Remin blank) and at the site (site-Remin samples) in this study indicate that leaching of nutrients could occur during post-treatment of RO permeate at the site (e.g., leaching of AOC and microbially available phosphate (Lehtola et al., 2002) from the calcite grains). This leaching was mainly observed when the calcite contactors were refilled with fresh calcite grains for remineralisation of RO permeate as a higher DOC concentration was measured in the instant effluent. Preventing water quality deterioration of RO permeate during post-treatment processes is a challenging from a practical standpoint, where RO permeate comes in contact with different materials (e.g., chemicals, fittings, pipes) which might leach nutrients.

Despite the increase in the BGP of RO permeate after the post-treatment processes, the BGP of site-Remin samples is still significantly lower (85\%) than that of CTW. The considerable reduction in $\mathrm{BGP}$ reflects the effectiveness of $\mathrm{RO}$ treatment in retaining bacterial cells and AOC content (Madaeni, 1999; Escobar et al., 2000; van der Bruggen and Vandecasteele, 2003; Hong et al., 2005; Park and Hu, 2010; Thayanukul et al., 2013; Belila et al., 2016) from the water to be treated, and thus limiting bacterial growth. AOC concentration in the site-Remin samples is estimated at $9 \pm 2 \mu \mathrm{g} / \mathrm{L}$ Ac-C using yield factors reported by Hammes and Egli (2005) and Prest et al. (2016a), and is in line with the findings of Park and $\mathrm{Hu}$ (2010). Although higher AOC concentrations have been reported for RO permeate (32-60 $\mu \mathrm{g} / \mathrm{L}$ Ac-C) (Hong et al., 2005; Meckes et al., 2007; Thayanukul et al., 2013), it comprised the lowest $\mathrm{AOC}$ concentrations among all the tested waters in those studies. The variation in AOC content of RO permeate can be largely attributed to the different methods applied to measure it (Ross et al., 2013) as discussed above. Moreover, different design of RO systems in the aforementioned studies (including post-treatment) may also affect the final AOC concentration. 
Further developing the bacterial growth potential method for ultra-pure drinking water

produced by remineralisation of reverse osmosis permeate

\subsubsection{Is there a need for pasteurisation as part of the BGP method?}

Pasteurisation is applied in several biological stability assessment methods to guarantee complete inactivation of indigenous bacteria before inoculating with pure bacterial strains (van der Kooij et al., 1982; Joret et al., 1991; van der Kooij, 1992; Sack et al., 2010; Sack et al., 2011). Some researchers argued that there is no need for pasteurisation to measure the extent of indigenous bacterial growth (Prest et al., 2016a) because of its potential effects on modifying the nutrients composition (e.g., proteins denaturing) which may increase the uncertainty of the measured values (Ross et al., 2013). However, in the present study, pasteurisation of water samples prior to BGP measurement was found to be necessary, even when considering indigenous bacteria for inoculation, to avoid the possible influence of abnormally elevated initial cell count on the typical shape of bacterial growth curves, and hence, BGP outcome. This was occasionally observed for non-pasteurised site-Remin samples when using fresh calcite grains for remineralisation where bacteria attached to the grains were washed-out. Similar fluctuations in cell concentrations in the effluent of biological filters have been previously observed and linked to the operating conditions (Servais et al., 1994; Velten et al., 2011).

However, under normal operating conditions, pasteurised and non-pasteurised samples after the calcite contactors reached comparable maximum levels regardless of their initial cell counts. This indicates that expressing the BGP results as the absolute maximum growth, rather than the net bacterial growth, is a better reflection of the actual total nutrient content of these water samples. For instance, considering net growth implies that part of the nutrients that are utilised by the cells initially present in the sample is totally neglected. This becomes even more critical and misleading when comparing waters with different initial levels of bacterial cells, which is the case of this study (i.e., CTW and site-Remin samples). Based on the aforementioned discussion, the comparable maximum growth levels in water samples without and with pasteurisation, under normal operating conditions, suggests that any modification to the nutrient content due to pasteurisation is limited. However, further research is recommended to investigate in depth the potential effect of pasteurisation on BGP measurement. Another advantage of pasteurisation, besides the fact that it controls the initial cell count in all samples quantitatively, is that it ensures that the bacterial species used for the test are the species that naturally grow in water. The case of an abnormal initial cell count implies that the bacterial species in the non-pasteurised sample are mostly attached bacteria onto calcite grains which may differ from the bulk water bacteria (Martiny et al., 2005; Bonadonna et al., 2009), and consequently have different yields. As a result, the attached bacteria may dominate the growth characteristics of the water samples, rather than the bulk water bacteria which are the target of the test. This is especially critical when bulk water bacteria vary significantly from bacteria that may be released from a filter bed. 
Further developing the bacterial growth potential method for ultra-pure drinking water produced by remineralisation of reverse osmosis permeate

Alternatively, pre-treatment of water samples with $0.22 \mu \mathrm{m}$ pore size filtration is another option to obtain a clear distinction between the initial and final cell count during the growth of natural bacterial consortia (i.e., net growth and specific growth rate) (Percherancier et al., 1996; Hammes and Egli, 2005). However, pre-treatment by pasteurisation is preferred over $0.22 \mu \mathrm{m}$ filtration in this study because of the ultra-low nutrient concentration and high sensitivity of RO permeate samples (i.e., lab-Remin and site-Remin) as even minor leaching of nutrients from the flushed filters can have significant influences on BGP measurement (as similarly observed for the influence of inoculation, i.e., $\triangle$ BGPconsortium).

\subsubsection{Practical implications of measuring low levels of BGP}

A new ultra-pure blank for the BGP method based on a laboratory remineralised RO permeate is proposed and applied in this study to assess the BGP of water produced by a pilot-scale RO system. There is no doubt that measuring the changes in microbiological water quality is essential for understanding and managing biological stability of drinking water. Thus, using an ultra-pure blank (including the lower detection limit and better reproducibility) makes it possible to push forward the monitoring and understanding of bacterial growth and microbiological quality of drinking water. This is especially true for drinking water with ultra-low levels of nutrients and cell counts produced by RO systems. Moreover, the lower detection limit of the BGP method can capture the potential of bacterial water quality deterioration after $\mathrm{RO}$ treatment.

However, it should also be clarified that the measurable increase in cell number does not necessarily mean that drinking water is biological unstable, or that there are problems associated with drinking water bio-safety. For instance, despite the release of cells and nutrients from the calcite contactors leading to measureable levels of bacterial growth, the finished water has $85 \%$ lower growth potential compared with conventionally treated water. The lower detection limit of the BGP methods has improved the sensitivity so that small water quality changes can be measured and acted upon.

Other researchers have suggested that a combination of cell number and bacterial community assessment can offer more insight into both the process of bacterial (re)growth and whether there is improvement or deterioration regarding health related bio-safety issues (Prest et al., 2014; Liu et al., 2018). Besides the biological stability (including both bacterial count and community), it is also interesting to look into how applying advanced water purification technologies can help to control the growth of target (opportunistic) pathogens. For instance, the relationship between BGP of total cells and BGP of Legionella spp., Aeromonas spp. or other pathogens (Vital et al., 2010), and to what extent drinking water with ultra-low levels of nutrients will be able to limit their growth in case of pipe cracks and bacterial intrusion into drinking water, especially when considering that organic carbon is not the growth-limiting factor for a group of the opportunistic pathogens, e.g., Legionella pneumophila (Williams et al., 2015). 
Further developing the bacterial growth potential method for ultra-pure drinking water produced by remineralisation of reverse osmosis permeate

\subsection{Conclusions}

The conclusions that can be drawn from this study are:

- The ultra-pure blank proposed in this study, laboratory remineralised RO permeate, has much lower BGP $\left(50 \pm 20 \times 10^{3} \mathrm{ICC} / \mathrm{mL}\right)$ and higher reproducibility than conventional blanks $\left(100 \times 10^{3}-600 \times 10^{3} \mathrm{ICC} / \mathrm{mL}\right)$, which led to lowering the detection limit of the BGP method.

- Depending on the concentration of the natural bacterial consortium used as inoculum $\left(>10 \times 10^{3} \mathrm{ICC} / \mathrm{mL}\right)$, it may have a significant influence on the measured BGP.

- Pasteurisation of water samples prior to measuring BGP is necessary to lower the initial number and ensure similar communities of cells in all samples. Further research is needed to assess the potential effect of pasteurisation on denaturing the organic nutrient content of water.

- Expressing BGP results as the absolute maximum growth, rather than the net growth, is a better reflection of the actual nutrient content of the water. This becomes even more critical when comparing the BGP of water with different backgrounds (e.g., initial number of cells).

- The BGP of finished drinking water has been reduced by $85 \%$ with RO filtration and post-treatment compared with conventional treatment of groundwater, from $630 \pm 70 \times 10^{3}$ to $90 \pm 20 \times 10^{3} \mathrm{ICC} / \mathrm{mL}$. 



\section{MEASURING BACTERIAL GROWTH POTENTIAL OF ULTRA-LOW NUTRIENT DRINKING WATER PRODUCED BY REVERSE OSMOSIS: EFFECT OF SAMPLE PRE-TREATMENT AND BACTERIAL INOCULUM}

This chapter is based on the following publication:

Sousi, M., Salinas-Rodriguez, S.G., Liu, G., Schippers, J.C., Kennedy, M.D., van der Meer, W., 2020. Measuring bacterial growth potential of ultra-low nutrient drinking water produced by reverse osmosis: Effect of sample pre-treatment and bacterial inoculum. Frontiers in Microbiology 11, 791. https://doi.org/10.3389/fmicb.2020.00791 
Measuring bacterial growth potential of ultra-low nutrient drinking water produced by reverse osmosis: Effect of sample pre-treatment and bacterial inoculum

\begin{abstract}
Bacterial growth potential (BGP) bioassay involves sample preparation and inoculation, which may introduce contaminants in ultra-low nutrient water (e.g., remineralised RO permeate) leading to unreliable BGP results. More specifically, sample pre-treatment can be performed by (i) pasteurisation, which may lead to denaturing of nutrients, or (ii) membrane filtration, which may leach/remove nutrients into/from water samples. In this study, the effect of pasteurisation and membrane filtration on the BGP of remineralised RO permeate was compared. In addition, inoculating remineralised $\mathrm{RO}$ permeate samples with bacteria naturally present in conventional drinking water may lead to undesired nutrient addition, and thus, increased BGP of the sample. In order to limit nutrient addition during inoculation, a bacterial inoculum originating from remineralised RO permeate was evaluated by comparing their ability to utilise organic carbon of various levels of complexity (acetate, glucose, laminarin, gelatin, and natural DOC) with the ability of other bacterial inocula originating from conventional drinking water and anaerobic groundwater. The results showed that membrane filtration pre-treatment increased the BGP of remineralised RO permeate by $140-320 \%$ despite extensive soaking and flushing of the filters ( $>350 \mathrm{hrs}$ ), whereas no effect was observed on the BGP of conventional drinking water owing to its high nutrient content. Pasteurisation pre-treatment had insignificant effects on the BGP of both water types. Bacteria in (remineralised) RO permeate showed limitations in utilising complex organic carbon which was effectively utilised by bacteria naturally present in conventional drinking water. In conclusion, the BGP bioassay for ultra-low nutrient water (e.g., remineralised RO permeate) should consider pasteurisation pre-treatment, and not using remineralised RO permeate bacteria for inoculation.
\end{abstract}

\title{
3.1 Introduction
}

Bacterial growth in water supply systems, whether in the form of planktonic bacteria or biofilms attached to surfaces in contact with water, is associated with health threats (e.g., diseases caused by pathogenic bacteria, such as Legionella pneumophila (Prest et al., 2016b)), operational problems of water supply (e.g., bio-corrosion of pipe material), and adverse effects on the aesthetic characteristics of drinking water (Volk and LeChevallier, 1999; Berry et al., 2006; Liu et al., 2017).

Controlling bacterial growth during water distribution, especially in non-chlorinated systems, requires the production of biologically stable drinking water with a very low concentration of biodegradable organic compounds that provide energy for bacterial bioprocesses and proliferation (Prest et al., 2016b; Nescerecka et al., 2018). Reverse osmosis (RO) filtration is capable of producing drinking water with ultra-low nutrient level, and thus, very low bacterial growth potential (BGP) (Park and Hu, 2010; Dixon et al., 2012). 
Measuring bacterial growth potential of ultra-low nutrient drinking water produced by reverse osmosis: Effect of sample pre-treatment and bacterial inoculum

However, Sousi et al. (2018) demonstrated that the existing BGP bioassays are not suitable for ultra-low nutrient water, such as remineralised RO permeate (BGP $=50 \times 10^{3}-100 \times$ $10^{3}$ cells $/ \mathrm{mL}$ ), because of their high detection limit. Additionally, more care should be taken when measuring the BGP of ultra-low nutrient water samples due to the high susceptibility of this water type to sample preparation procedures that can introduce contamination (i.e., BGP increase). There are several methodological aspects that can affect obtaining reliable BGP results, including glassware preparation, surrounding laboratory environment, chemicals addition, sample pre-treatment, and inoculation. This study, however, focused on the last two aspects (i.e., sample pre-treatment and inoculation) due to their potentially high effect, and the variation of sample pre-treatment methods and inoculum types proposed in the literature as explained below.

Sample pre-treatment is performed to inactivate or remove indigenous bacteria, where membrane filtration $(0.1-\mu \mathrm{m}$ or $0.2-\mu \mathrm{m})$ (Servais et al., 1987; Percherancier et al., 1996; Hammes and Egli, 2005), pasteurisation $\left(60\right.$ or $70{ }^{\circ} \mathrm{C}$ ) (van der Kooij et al., 1982; Joret et al., 1991; van der Kooij, 1992; Sack et al., 2010; Sack et al., 2011), or a combination of these two methods (Park et al., 2016) are used. Alternatively, some bioassays consider no sample pre-treatment (i.e., direct incubation) (Prest et al., 2016a), arguing that it may affect the nutrient nature in water (Ross et al., 2013). However, Sousi et al. (2018) demonstrated that pre-treatment is needed for ultra-low nutrient water samples in which initial cell count exceeded the available nutrients for bacterial growth (e.g., wash-out of bacterial loads from filtration units), leading to a decreasing number of cells over time directly after starting the bioassay. The main disadvantage of pasteurisation is that it may affect the nature of organic compounds in water, whereas filtration may either remove or leach nutrients from/into water (Khan and Subramania-Pillai, 2006), resulting in unreliable BGP outcome. Although researchers in this field are aware of these potential drawbacks (Ross et al., 2013), no explicit studies have been conducted to assess the effects of sample pre-treatment on the BGP outcome.

Inoculating ultra-low nutrient water samples after pre-treatment with natural bacteria is essential to initiate growth, where undesired nutrient addition can occur when using nutrient-rich water as an inoculum source (Sousi et al., 2018). Instead, ultra-low nutrient water (e.g., remineralised RO permeate) can be used as an inoculum source to reduce the undesired nutrient addition, especially that (remineralised) RO permeate bacteria are best adapted to grow in their own water without the need for an external inoculum as demonstrated by Sousi et al. (2018), which was also observed for other water types (Farhat et al., 2018). However, investigating the ability of (remineralised) RO permeate bacteria to utilise organic carbon of various complexity levels is first needed, especially with the considerably low diversity of the RO permeate bacterial species (Belila et al., 2016).

The BGP bioassay based on cell count is considered for this study, where the results can be expressed as the maximum cell count obtained during the incubation period (Sousi et al., 
Measuring bacterial growth potential of ultra-low nutrient drinking water produced by reverse osmosis: Effect of sample pre-treatment and bacterial inoculum

2018), or as the net bacterial growth which is the difference between the initial and maximum cell counts as in the direct incubation methods (Prest et al., 2016a; Nescerecka et al., 2018).

The objective of this study was, therefore, to assess the effect of sample pre-treatment by pasteurisation and membrane filtration on the BGP (i.e., maximum and net bacterial growth) of ultra-low nutrient drinking water produced by RO filtration and remineralisation. In addition, the possibility of using bacteria naturally present in remineralised RO permeate as inoculum for BGP measurements was investigated by testing their ability to utilise organic carbon with various molecular characteristics.

\subsection{Materials and methods}

\subsubsection{Water samples}

This study was conducted on the Oasen's drinking water treatment plant (Kamerik, Netherlands), which produces $340 \mathrm{~m}^{3} / \mathrm{h}$ of drinking water by conventional treatment of anaerobic groundwater. The treatment consists of dry sand filtration, pellet softening, rapid sand filtration, activated carbon filtration (15 min), and medium-pressure ultraviolet disinfection $\left(20 \mathrm{~mJ} / \mathrm{cm}^{2}\right)$. For research purposes, anaerobic groundwater is also treated by a pilot-scale advanced treatment unit $\left(7 \mathrm{~m}^{3} / \mathrm{h}\right)$ comprising anaerobic RO filtration $(75 \%$ total recovery), followed by post-treatment processes: ion exchange, remineralisation using calcite contactors, and tower aeration. Finished waters of both treatment lines, i.e., conventionally treated water after the clean water reservoir (CTW) and site-remineralised RO permeate after all post-treatment processes (site-Remin), were sampled for BGP measurement. Properties and composition of CTW and site-Remin are given in Table 3.1. In addition, water collected directly after RO filtration (i.e., RO permeate) was used as a blank for BGP measurements as described in the following section. Lastly, anaerobic groundwater $(\mathrm{AGW})$ and activated carbon filtrate $(\mathrm{ACF})$ were used as sources for natural bacterial inoculum. Samples were collected on a monthly basis in the period between October 2016 and December 2018.

\subsubsection{Bacterial growth potential (BGP) bioassay}

The BGP bioassay proposed by Sousi et al. (2018) was applied in this study, in short:

Sample collection: water samples were collected in AOC-free glassware, which have been muffled at $550{ }^{\circ} \mathrm{C}$ for $6 \mathrm{~h}$ (Prest et al., 2016a).

Sample handling: water samples were pre-treated to inactivate indigenous bacteria prior to the addition of a natural bacterial inoculum. The full pre-treatment and inoculation details 
Measuring bacterial growth potential of ultra-low nutrient drinking water produced by reverse osmosis: Effect of sample pre-treatment and bacterial inoculum

are given in the following section. Thereafter, each water sample was divided into three AOC-free glass vials, which were incubated in the dark at $30{ }^{\circ} \mathrm{C}$ for 20 days.

Flow cytometry (FCM): cell count in the incubated water samples was measured (more frequently in the first week) using BD Accuri $\mathrm{C}^{\circledR}{ }^{\circledR} \mathrm{FCM}$ (BD Biosciences, Belgium) as described by Prest et al. (2016a), where only intact cell count (ICC) was reported as the increase in total cell count was mainly due to the new intact cells formed (Figure 3.1). Intact cells were stained with a mix of SYBR Green I (1:100) and propidium iodide (0.3 mM PI), where $5 \mu \mathrm{L}$ stain was added to $500 \mu \mathrm{L}$ of pre-heated samples at $35 \pm 2{ }^{\circ} \mathrm{C}$. Thereafter, samples were post-heated at the same temperature for $10 \mathrm{~min}$ before conducting the FCM measurements.

The blank: The BGP blank was prepared by remineralising RO permeate at the laboratory with $122 \mathrm{mg} / \mathrm{L} \mathrm{HCO}_{3}{ }^{-}$(final $\mathrm{pH}$ of $7.8 \pm 0.2$ ), $40 \mathrm{mg} / \mathrm{L} \mathrm{Ca}^{2+}, 4 \mathrm{mg} / \mathrm{L} \mathrm{Mg}^{2+}, 5 \mu \mathrm{g} / \mathrm{L} \mathrm{PO} 4-\mathrm{P}$, and $50 \mu \mathrm{g}-\mathrm{N} / \mathrm{L}$. The blank (laboratory-remineralised RO permeate) is denoted as lab-Remin and has a BGP of $50 \pm 20 \times 10^{3} \mathrm{ICC} / \mathrm{mL}$.

Table 3.1. Properties and composition of conventionally treated water (CTW) and siteremineralised RO permeate (site-Remin).

\begin{tabular}{|c|c|c|}
\hline Parameter (unit) & CTW & site-Remin \\
\hline $\mathrm{T}\left({ }^{\circ} \mathrm{C}\right)$ & 11.8 & 12.7 \\
\hline $\mathrm{pH}(-)$ & 8.1 & 7.8 \\
\hline Turbidity (FTE) & $<0.1-0.4$ & $<0.1-0.3$ \\
\hline $\mathrm{O}_{2}(\mathrm{mg} / \mathrm{L})$ & 8.3 & 9.1 \\
\hline SI (-) & $-0.07-0.18$ & $-4.38-0.23$ \\
\hline Total hardness $(\mathrm{mmol} / \mathrm{L})$ & 1.2 & 1.1 \\
\hline Conductivity (mS/m) & 63.225 & 20.94063 \\
\hline Hydrogen carbonate $(\mathrm{mg} / \mathrm{L})$ & 219.5 & 132.2 \\
\hline $\mathrm{Cl}(\mathrm{mg} / \mathrm{L})$ & 74.6 & n.a. \\
\hline $\mathrm{F}(\mathrm{mg} / \mathrm{L})$ & 0.1 & $<0.02$ \\
\hline $\mathrm{Al}(\mu \mathrm{g} / \mathrm{L})$ & 3.8 & n.a. \\
\hline $\mathrm{SO}_{4}(\mathrm{mg} / \mathrm{L})$ & 50.7 & n.a. \\
\hline $\mathrm{Na}(\mathrm{mg} / \mathrm{L})$ & 101.6 & n.a. \\
\hline $\mathrm{Fe}(\mathrm{mg} / \mathrm{L})$ & 0.01 & n.a. \\
\hline $\mathrm{Mg}(\mathrm{mg} / \mathrm{L})$ & 15.5 & 3.5 \\
\hline $\mathrm{Mn}(\mathrm{mg} / \mathrm{L})$ & $<0,005$ & $<0,005$ \\
\hline $\mathrm{Ca}(\mathrm{mg} / \mathrm{L})$ & 22.7 & 40.4 \\
\hline $\mathrm{DOC}(\mathrm{mg}-\mathrm{C} / \mathrm{L})$ & 6.4 & $<0.2$ \\
\hline $\mathrm{NH}_{4}\left(\mathrm{mg} / \mathrm{L} \mathrm{NH}_{4}-\mathrm{N}\right)$ & $<0.02$ & $<0.02$ \\
\hline $\mathrm{NO}_{2}\left(\mathrm{mg} / \mathrm{L} \mathrm{NO}_{2}-\mathrm{N}\right)$ & $<0.003$ & $<0.003$ \\
\hline $\mathrm{NO}_{3}\left(\mathrm{mg} / \mathrm{L} \mathrm{NO}_{3}-\mathrm{N}\right)$ & 2.89 & 0.23 \\
\hline
\end{tabular}


Measuring bacterial growth potential of ultra-low nutrient drinking water produced by reverse osmosis: Effect of sample pre-treatment and bacterial inoculum

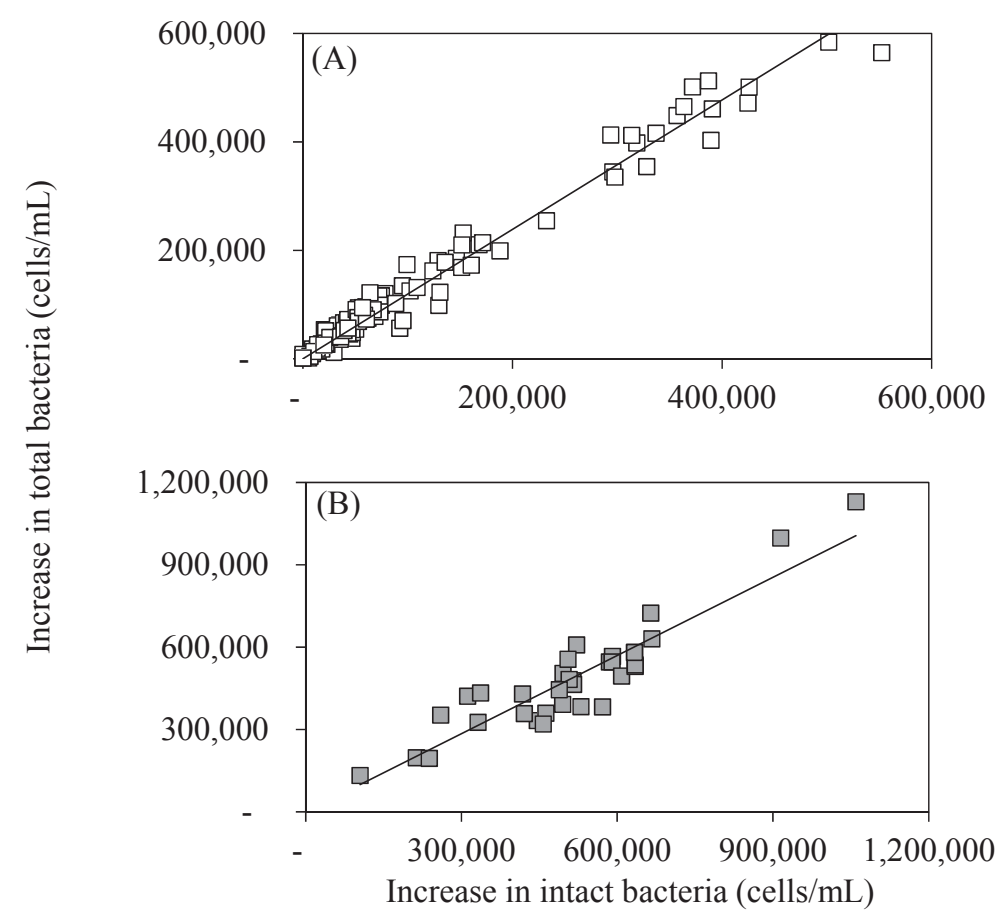

Figure 3.1. The relationship between the increase in total and intact bacterial cells in lab- and site-remineralised RO permeate (lab-Remin, site-Remin, A) and conventionally treated water (CTW, B).

\subsubsection{Experimental approach}

The following methodological aspects were investigated:

i. The effect of sample pre-treatment was studied by measuring the BGP of lab-Remin, site-Remin, and CTW samples with different pre-treatments: pasteurisation at $70{ }^{\circ} \mathrm{C}$ for 30 min using a water bath (type 1008 Water Bath, GFL, Germany), autoclaving at $121{ }^{\circ} \mathrm{C}$ for $15 \mathrm{~min}$ (3870 ELV autoclave, Tuttnauer Europe, Netherlands), and membrane filtration using gamma-sterilised polyethersulfone filters $(0.22-\mu \mathrm{m}$ pore size, 33-mm diameter, Merck Millipore Ltd., Ireland). Pre-treatment by pasteurisation or autoclaving was carried out on $200 \mathrm{~mL}$ of water sample contained in $250 \mathrm{~mL}$ Duran glassware, where the effective heating time was calculated after the water samples reached the required temperature. Thereafter, samples were cooled down to room temperature $\left(\sim 20{ }^{\circ} \mathrm{C}\right)$ in an ice bath before any further handling. Moreover, pasteurisation for a longer duration (45, 60, 90, and $120 \mathrm{~min}$ ) was carried out on CTW samples to investigate the effect of heat duration on 
Measuring bacterial growth potential of ultra-low nutrient drinking water produced by reverse osmosis: Effect of sample pre-treatment and bacterial inoculum

denaturing of nutrients. Regarding membrane filtration, all filters and syringes were thoroughly cleaned before using by soaking for $360 \mathrm{~h}$ in ultra-pure water (Milli-Q ${ }^{\circledR}$ water, Merck Millipore) interspersed with daily flushing (200 mL Milli-Q water) to avoid leaching of organic carbon in the samples. Water samples were filtered in 250 $\mathrm{mL}$ Duran glassware before distributing in triplicate vials. Additionally, BGP of non-pre-treated samples was measured as a control. The potential denaturing of nutrients due to sample pre-treatment was studied by analysing the water samples before and after pre-treatment for: AOC (P17/NOX) (van der Kooij and Hijnen, 1984), dissolved organic carbon (DOC) (Shimadzu TOC-L, Japan), and liquid chromatography-organic carbon detection (LC-OCD) (Huber et al., 2011) to measure the biodegradable fractions of DOC (e.g., biopolymers and humic substances).

ii. The ability of (remineralised) RO permeate bacteria to utilise readily available (glucose and acetate) and complex (laminarin, gelatin, and natural DOC) organic compounds was tested. The bacterial yield (based on BGP at 0,50 , and $500 \mu \mathrm{g}-\mathrm{C} / \mathrm{L}$ final concentration in the sample) was calculated for lab-Remin (the blank) without inoculation (i.e., only indigenous bacteria of RO permeate are present, $<10^{3} \mathrm{ICC} / \mathrm{mL}$ with FCM) and with the addition of 4 different natural bacterial inocula: site-Remin, $\mathrm{CTW}, \mathrm{ACF}$, or AGW. The final inoculum concentration in the water sample was in the range of $2 \times 10^{3}-10 \times 10^{3} \mathrm{ICC} / \mathrm{mL}(1.7 \pm 0.2 \%, \mathrm{v} / \mathrm{v})$, depending on the initial cell count of the inoculum source, which was in average: $25 \times 10^{3}, 600 \times 10^{3}, 500 \times$ $10^{3}$, and $290 \times 10^{3} \mathrm{ICC} / \mathrm{mL}$, for site-Remin, CTW, ACF, and AGW, respectively. Stock solutions $(1,000 \pm 50 \mathrm{mg}-\mathrm{C} / \mathrm{L})$ of sodium acetate, glucose, laminarin (from Laminaria digitata), and gelatin (type $\mathrm{B}$, from bovine skin) were prepared using Milli-Q water in AOC-free bottles and kept at $4{ }^{\circ} \mathrm{C}$. Additionally, RO concentrate was used as a source of natural DOC $(\sim 33 \mathrm{mg}-\mathrm{C} / \mathrm{L})$, where it was filtrated $(0.45-\mu \mathrm{m}$ pore size, PVDF, 33-mm Ø, Merck Millipore Ltd., Ireland), pasteurised $\left(70{ }^{\circ} \mathrm{C}\right.$ for $30 \mathrm{~min})$, and then filtrated again $(0.45-\mu \mathrm{m})$ to ensure complete removal of suspended particles and bacteria. The treated $\mathrm{RO}$ concentrate was added to lab-Remin at a ratio of $\sim 8 \%$ to obtain a final DOC concentration of $2.7 \mathrm{mg}-\mathrm{C} / \mathrm{L}$. Phosphate $\left(5 \mu \mathrm{g} / \mathrm{L} \mathrm{PO}_{4}-\right.$ P) and nitrogen $(50 \mu \mathrm{g}-\mathrm{N} / \mathrm{L})$ were added to all the samples, regardless of the added carbon concentration, to ensure that carbon was the growth-limiting factor during the test.

Lastly, BGP results can be expressed as maximum bacterial growth (BGP $\max$ ) or net bacterial growth (BGP net$_{\text {) }}$ as illustrated in Figure 3.2. Both ways of expressing BGP results were assessed by measuring the BGP of pasteurised CTW after inoculation with three different concentrations of bacteria originating from the same water type: $10 \times 10^{3}, 100 \times$ $10^{3}$, and $250 \times 10^{3} \mathrm{ICC} / \mathrm{mL}$. The BGP of non-pre-treated and non-inoculated CTW was measured as a control. 
Measuring bacterial growth potential of ultra-low nutrient drinking water produced by reverse osmosis: Effect of sample pre-treatment and bacterial inoculum

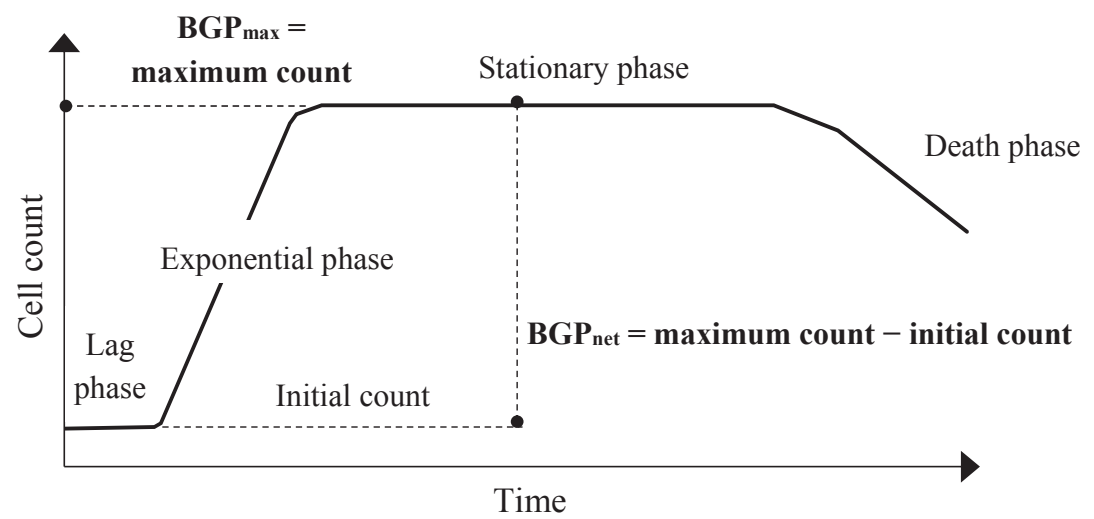

Figure 3.2. Typical bacterial growth curve illustrating the different ways of expressing bacterial growth potential (BGP) results: maximum bacterial growth $\left(\right.$ BGP $\left._{\max }\right)$ and net bacterial growth $\left(\mathbf{B G P}_{\text {net }}\right)$.

\subsubsection{Statistical analysis}

Student's $t$-test and one-way analysis of variance (ANOVA) were used to determine the significance of differences between samples with normally distributed data (affirmed by QQ plots, Chi-squared tests, and Kolmogorov-Smirnov tests). In addition, a simple linear correlation between two quantitative variables was applied. The Microsoft Excel software was used for statistical analysis with $95 \%$ confidence (alpha of 0.05 ).

\subsection{Results}

\subsubsection{Expressing BGP results}

The maximum bacterial growth $\left(\mathrm{BGP}_{\max }\right)$ of pasteurised and inoculated conventionally treated water (CTW) remained in the range of $650 \times 10^{3}-700 \times 10^{3} \mathrm{ICC} / \mathrm{mL}$ regardless of the initial cell count which varied from $100 \times 10^{3}-600 \times 10^{3} \mathrm{ICC} / \mathrm{mL}$ (Figure 3.3). As a result, the net bacterial growth $\left(\mathrm{BGP}_{\text {net }}\right)$ varied significantly among the samples $(P<0.05)$. Interestingly, pasteurisation (at $70{ }^{\circ} \mathrm{C}$ for $30 \mathrm{~min}$ ) was not sufficient to completely remove intact cells, where $100 \times 10^{3} \mathrm{ICC} / \mathrm{mL}$ were found in the pasteurised CTW before inoculation. Those pasteurisation-resistant cells seemed to be inactive, as no bacterial growth was observed in the pasteurised but not inoculated CTW samples during the 20-day incubation period. However, a long term test showed that bacterial growth occurred at a very low rate, 
Measuring bacterial growth potential of ultra-low nutrient drinking water produced by reverse osmosis: Effect of sample pre-treatment and bacterial inoculum

where the bacterial count reached $280 \times 10^{3} \mathrm{ICC} / \mathrm{mL}$ after about 80 days of incubation (data not shown).

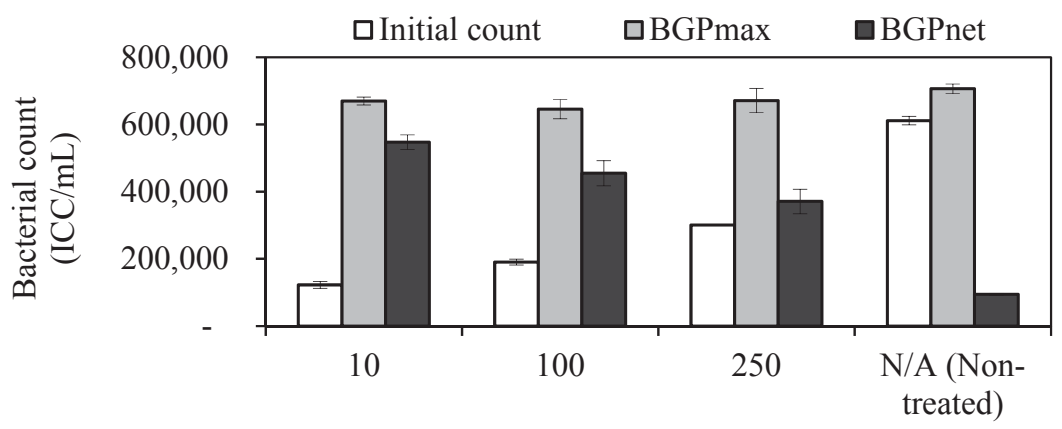

Inoculum concentration $\left(\times 10^{3} \mathrm{ICC} / \mathrm{mL}\right)$

Figure 3.3. Initial cell count, maximum bacterial growth potential (BGP $\max$ ), and net bacterial growth potential $\left(\mathbf{B G P}_{\text {net }}\right)$ of pasteurised conventionally treated water with varying inoculum concentration $\left(10 \times 10^{3}, 100 \times 10^{3}\right.$ and $\left.250 \times 10^{3} \mathrm{ICC} / \mathrm{mL}\right)$ originating from the same water. Error bars represent the measurement variations of 3 separate tests, with triplicate vials per test.

\subsubsection{Effect of sample pre-treatment on BGP}

The effect of sample pre-treatment on the BGP of water was highly dependent on the type of water. The results (Figure 3.4) revealed that the BGP $\max$ of CTW was comparable $(P>$ $0.05)$ whether the samples were non-pre-treated $\left(677 \pm 60 \times 10^{3} \mathrm{ICC} / \mathrm{mL}\right.$, the control) or pre-treated by pasteurisation $\left(610 \pm 25 \times 10^{3} \mathrm{ICC} / \mathrm{mL}\right)$ or $0.22-\mu \mathrm{m}$ filtration $\left(655 \pm 40 \times 10^{3}\right.$ $\mathrm{ICC} / \mathrm{mL})$. Moreover, pasteurisation of the CTW samples for a longer period $(45,60,90$, and $120 \mathrm{~min}$ ) had minor influences on the BGP $\max$ (Figure 3.5). In contrast, the BGP $\max$ of the autoclaved CTW samples increased by $75-85 \%$ (to $1,180 \pm 160 \times 10^{3} \mathrm{ICC} / \mathrm{mL}$ ).

For ultra-low nutrient water (i.e., the lab-Remin blank and site-Remin), insignificant ( $P>$ $0.05)$ differences in $\mathrm{BGP}_{\max }$ were observed between the pasteurised and non-pre-treated (the control) samples. The BGP $\max$ of lab-Remin was $41 \pm 8 \times 10^{3}$ and $40 \pm 5 \times 10^{3} \mathrm{ICC} / \mathrm{mL}$ for the pasteurised and non-pre-treated samples, respectively, and the corresponding $\mathrm{BGP}_{\max }$ of site-Remin was $98 \pm 2 \times 10^{3}$ and $94 \pm 5 \times 10^{3} \mathrm{ICC} / \mathrm{mL}$. Unlike the results for CTW, 0.22- $\mu \mathrm{m}$ filtration had a substantial influence on the BGP ${ }_{\max }$ of lab-Remin, which increased by $140-320 \%$ (to $180 \pm 60 \times 10^{3} \mathrm{ICC} / \mathrm{mL}$ ) in the samples pre-treated by filtration. 
Measuring bacterial growth potential of ultra-low nutrient drinking water produced by reverse osmosis: Effect of sample pre-treatment and bacterial inoculum

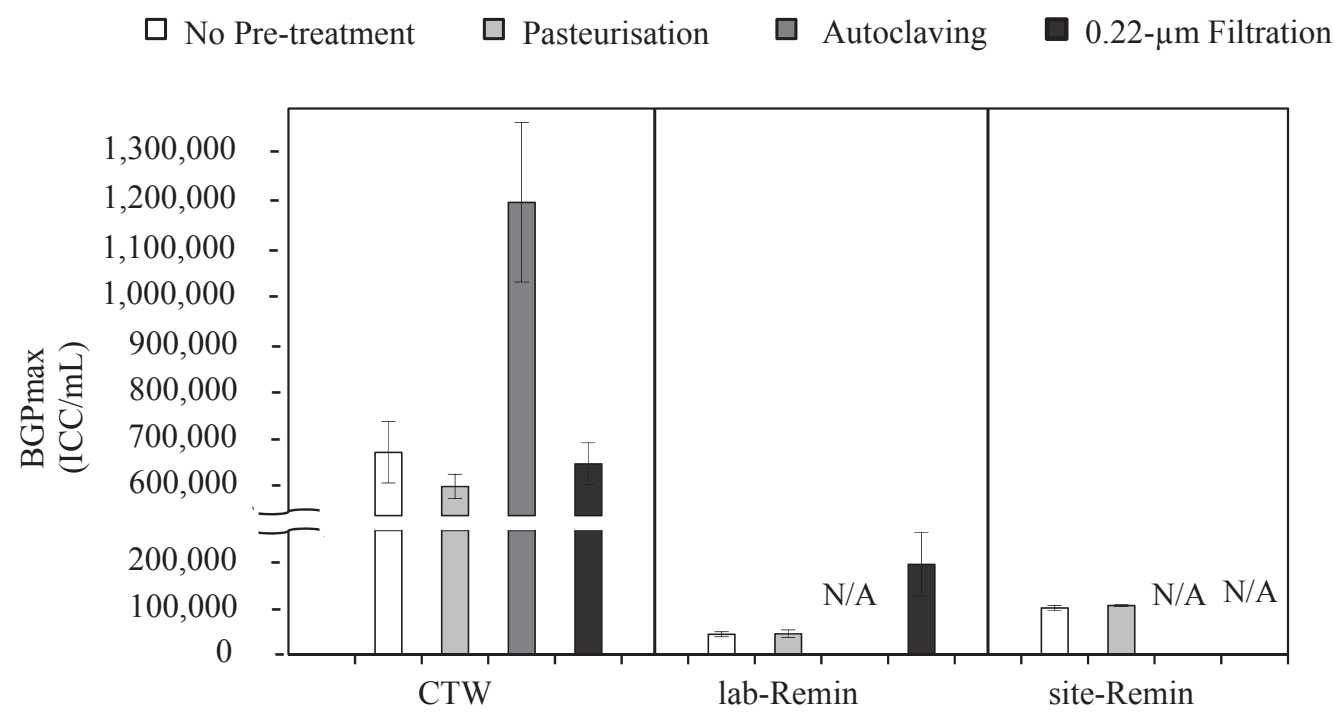

Figure 3.4. Maximum bacterial growth potential $\left(\mathrm{BGP}_{\max } ; 20\right.$ days at $\left.30{ }^{\circ} \mathrm{C}\right)$ of non-pretreated, pasteurised $\left(70^{\circ} \mathrm{C}\right.$ for $\left.30 \mathrm{~min}\right)$, sterilised $\left(121^{\circ} \mathrm{C}\right.$ for $\left.15 \mathrm{~min}\right)$, and $0.22-\mu \mathrm{m}$ filtrated water samples of lab-remineralised RO permeate (lab-Remin, the blank), site-remineralised RO permeate (site-Remin), and conventionally treated water (CTW). All samples were inoculated with CTW whether pre-treated or not. Error bars represent the measurement variations of 3 separate tests, with triplicate vials per test. N/A, not available.

Notably, the AOC concentration in the samples (slightly) increased after any pre-treatment (Table 3.2) including pasteurisation which had minor effects on the BGP results. The increase in AOC concentration ranged from 1 (in lab-Remin and site-Remin) to $8 \mu \mathrm{g} / \mathrm{L} \mathrm{Ac-}$ $\mathrm{C}$ (in CTW) depending on the pre-treatment applied, and it was not strongly correlated with the increase in $\mathrm{BGP}_{\max }\left(\mathrm{R}^{2}=0.40\right)$. Moreover, the concentrations of DOC and biodegradable carbon fractions measured by LC-OCD remained unchanged (Table 3.2, DOC: $5.9 \pm 0.1$ $\mathrm{mg}-\mathrm{C} / \mathrm{L}$ for $\mathrm{CTW}$, and $<0.2 \mathrm{mg}-\mathrm{C} / \mathrm{L}$ for site-Remin and lab-Remin) regardless of the pretreatment applied.

\subsubsection{Assessing the ability of (remineralised) RO permeate bacteria to utilise organic carbon}

The growth of natural bacterial consortia on organic carbon varied according to the source of bacteria as well as the type of organic carbon (Figure 3.6). The BGP max $_{\text {ox }}$ of lab-Remin increased linearly with the addition of glucose and acetate, whether lab-Remin was not inoculated (i.e., only indigenous bacteria of RO permeate are present) or inoculated with 
Measuring bacterial growth potential of ultra-low nutrient drinking water produced by reverse osmosis: Effect of sample pre-treatment and bacterial inoculum

different natural bacterial consortia (i.e., site-Remin, ACF, CTW, and AGW). Moreover, the $\mathrm{BGP}_{\max }$ was obtained within 2 to 5 days of incubation, reflecting the high biodegradability of glucose and acetate. The bacterial yield on glucose and acetate was comparable $(P>0.05)$ irrespective of the inoculum type, where the average yield was 5.00 $\pm 0.65 \times 10^{6}$ cells $/ \mu \mathrm{g}-\mathrm{C}$ for glucose (Figure $3.7 \mathrm{~A}$ ) and $4.45 \pm 0.35 \times 10^{6} \mathrm{cells} / \mu \mathrm{g}-\mathrm{C}$ for acetate (Figure 3.7B).

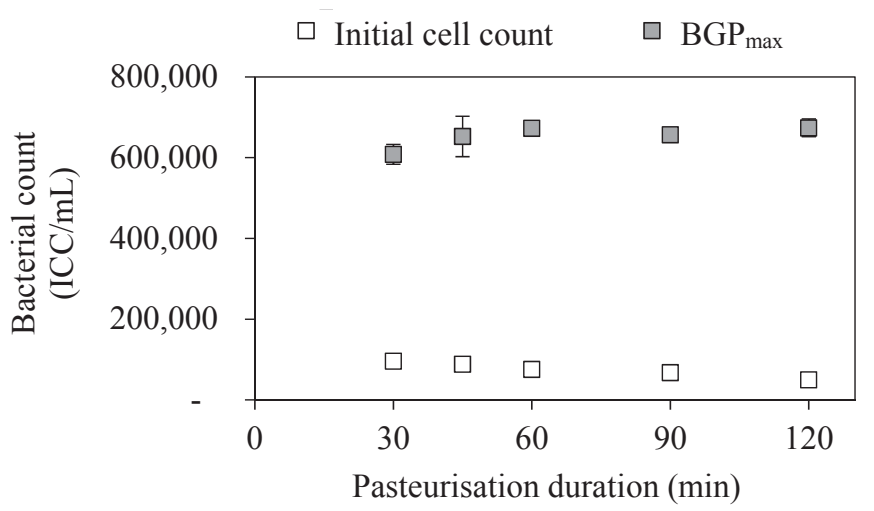

Figure 3.5. Initial cell count and maximum bacterial growth potential $\left(B_{G} P_{\max }\right)$ of conventionally treated water (CTW) with different pasteurisation durations. Inoculum of 10 $\times 10^{3} \mathrm{ICC} / \mathrm{mL}$ originating from the same water was added. Error bars represent the measurement variations of 3 separate tests, with triplicate vials per test (in total, $n=9$ ). Growth rate $(\mu)$ was in the range of $0.85-1.00 d^{-1}$ for all samples.

On the other hand, the BGP $\max$ on complex organic carbon (i.e., laminarin, gelatin, and natural DOC) was obtained within 10 to 15 days of incubation, and it was highly dependent on the inoculum type. For instance, the BGP $\max$ obtained for non-inoculated lab-Remin was significantly $(P<0.05)$ lower than that obtained for inoculated lab-Remin. The growth in non-inoculated lab-Remin was partially limited when laminarin was used as the sole carbon source (Figure 3.7C), where the bacterial yield was $2.25 \pm 0.75 \times 10^{6} \mathrm{cells} / \mu \mathrm{g}-\mathrm{C}$ compared with the average of $4.10 \pm 0.35 \times 10^{6}$ cells $/ \mu \mathrm{g}-\mathrm{C}$ observed for the other inocula combined. Moreover, the growth in non-inoculated lab-Remin was considerably low when gelatin was used as the sole carbon source (Figure 3.7D), where the bacterial yield was negligible (0.05 $\left.\pm 0.04 \times 10^{6} \mathrm{cell} / \mu \mathrm{g}-\mathrm{C}\right)$. The yield in lab-Remin spiked with gelatin was also limited when AGW was used an inoculum $\left(1.95 \pm 0.45 \times 10^{6}\right.$ cells $\left./ \mu \mathrm{g}-\mathrm{C}\right)$ compared with site-Remin, $\mathrm{ACF}$, and CTW inocula $\left(5.70 \pm 0.80 \times 10^{6} \mathrm{cells} / \mu \mathrm{g}-\mathrm{C}\right)$. 
Measuring bacterial growth potential of ultra-low nutrient drinking water produced by reverse osmosis: Effect of sample pre-treatment and bacterial inoculum

\begin{tabular}{|c|c|c|c|c|c|c|c|c|c|c|}
\hline \multirow{4}{*}{ U } & तิ่ & $\begin{array}{l}+1 \\
n \\
6\end{array}$ & $\overleftrightarrow{z}$ & $\overleftrightarrow{\mathrm{Z}}$ & $\overleftrightarrow{\mathrm{z}}$ & $\overleftrightarrow{Z}$ & $\overleftrightarrow{\mathrm{z}}$ & $\overleftrightarrow{\mathrm{z}}$ & $\overleftrightarrow{\mathrm{z}}$ & $\overleftrightarrow{Z}$ \\
\hline & 总 & 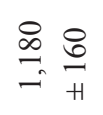 & $\stackrel{H}{\stackrel{H}{0}}$ & \&े & 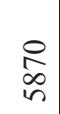 & $\frac{8}{\mathrm{~V}}$ & 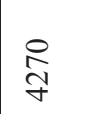 & ¿ & 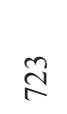 & 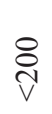 \\
\hline & 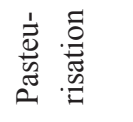 & $\frac{1}{0} \sqrt{0}$ & 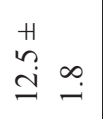 & 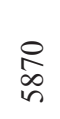 & $\begin{array}{l}\mathscr{D} \\
\infty \\
i n\end{array}$ & $\frac{8}{\mathrm{v}}$ & 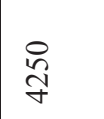 & $\stackrel{N}{a}$ & $\stackrel{0}{\mathbb{1}}$ & $\stackrel{\mathbb{N}}{\mathrm{V}}$ \\
\hline & 咅离 & $\stackrel{+}{\text { H }} 8$ & 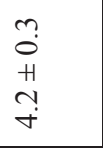 & \&్రి & $\stackrel{8}{\circ}$ & $\stackrel{8}{\mathrm{~V}}$ & 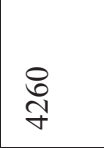 & ڤे & ț & $\stackrel{\stackrel{\leftrightarrow}{V}}{\mathrm{~V}}$ \\
\hline \multirow{4}{*}{ 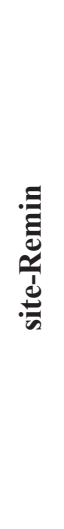 } & તุ่ & $\overleftrightarrow{\mathrm{Z}}$ & $\overleftrightarrow{\mathrm{z}}$ & $\overleftrightarrow{\mathrm{z}}$ & $\overleftrightarrow{\mathrm{z}}$ & $\overleftrightarrow{\mathrm{Z}}$ & $\overleftrightarrow{\mathrm{z}}$ & $\overleftrightarrow{\mathrm{Z}}$ & $\overleftrightarrow{\mathbb{Z}}$ & $\overleftrightarrow{\mathrm{z}}$ \\
\hline & 官 & $\overleftrightarrow{\mathrm{Z}}$ & $\overleftrightarrow{Z}$ & $\overleftrightarrow{\mathrm{z}}$ & $\overleftrightarrow{\mathrm{z}}$ & $\overleftrightarrow{Z}$ & $\overleftrightarrow{\mathrm{z}}$ & $\overleftrightarrow{\Xi}$ & $\overleftrightarrow{Z}$ & $\overleftrightarrow{Z}$ \\
\hline & 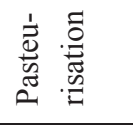 & $\begin{array}{l}1 \\
+1 \\
\infty \\
\infty\end{array}$ & $\stackrel{+}{+} \stackrel{0}{\circ}$ & $\stackrel{\stackrel{্}{V}}{\mathrm{~V}}$ & $\stackrel{\stackrel{\Xi}{V}}{\mathrm{~V}}$ & $\stackrel{\&}{\mathrm{~V}}$ & ¿̊. & $\stackrel{\stackrel{\Xi}{V}}{\mathrm{~V}}$ & ¿े & $\stackrel{\stackrel{\sim}{V}}{\mathrm{~V}}$ \\
\hline & 咅总 & $\begin{array}{l}n \\
+1 \\
0 \\
+\end{array}$ & $\begin{array}{l}\overrightarrow{0} \\
+ \\
9 \\
-\end{array}$ & $\stackrel{\mathbb{N}}{\mathrm{V}}$ & 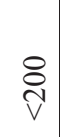 & $\frac{8}{\mathrm{~V}}$ & 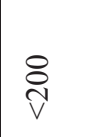 & ¿্ণ & $\underset{\mathbb{N}}{8}$ & $\stackrel{\mathbb{N}}{\mathrm{V}}$ \\
\hline \multirow{4}{*}{ 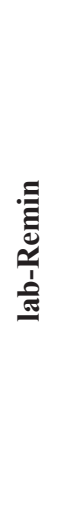 } & તิ่ & $\stackrel{+}{\stackrel{0}{\infty}} 8$ & $\stackrel{+}{\stackrel{+}{\sim}} \stackrel{\text { O }}{-}$ & 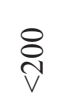 & ¿ั. & $\frac{8}{\mathrm{v}}$ & ปั. & \ั. & ¿্ণ & ¿্ं \\
\hline & 宾 竞 & $\overleftrightarrow{\mathrm{z}}$ & $\overleftrightarrow{\mathrm{z}}$ & $\overleftrightarrow{\mathrm{z}}$ & $\underset{\mathrm{z}}{\overleftrightarrow{\mathrm{z}}}$ & $\overleftrightarrow{Z}$ & $\overleftrightarrow{\mathrm{z}}$ & $\overleftrightarrow{\nwarrow}$ & $\overleftrightarrow{\mathbb{z}}$ & $\overleftrightarrow{\mathrm{Z}}$ \\
\hline & 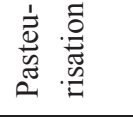 & $\begin{array}{l}\infty \\
+ \\
F\end{array}$ & $\begin{array}{ll}+ & \\
+ & -1 \\
i n & 0\end{array}$ & 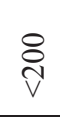 & 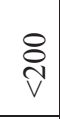 & $\frac{8}{\mathrm{~V}}$ & 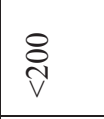 & $\begin{array}{l}\stackrel{N}{V} \\
\text { V }\end{array}$ & 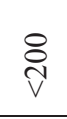 & 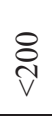 \\
\hline & 咅 & $\begin{array}{l}n \\
\text { n } \\
q \\
q\end{array}$ & 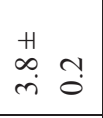 & ¿ి & $\begin{array}{l}\stackrel{\mathrm{N}}{\mathrm{V}} \\
\end{array}$ & $\stackrel{8}{\mathrm{~V}}$ & 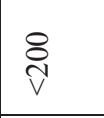 & 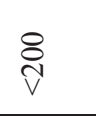 & 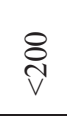 & ¿্ত \\
\hline & & ) & 0. & 8 & ○ & 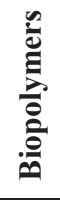 & 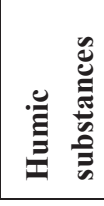 & 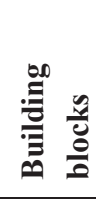 & $\frac{\frac{n}{\pi}}{\tilde{E}}$ & $\frac{a}{20}$ \\
\hline & & 읍 & 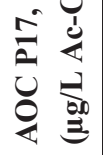 & & & & 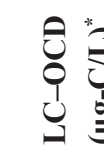 & & & \\
\hline
\end{tabular}


Measuring bacterial growth potential of ultra-low nutrient drinking water produced by reverse osmosis: Effect of sample pre-treatment and bacterial inoculum

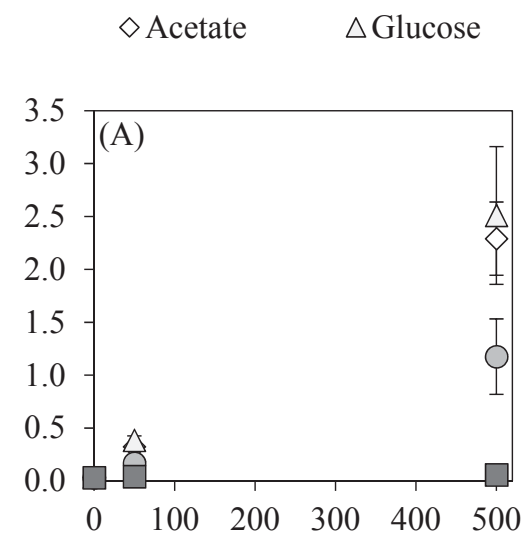

\section{OLaminarin $\quad \square$ Gelatin}
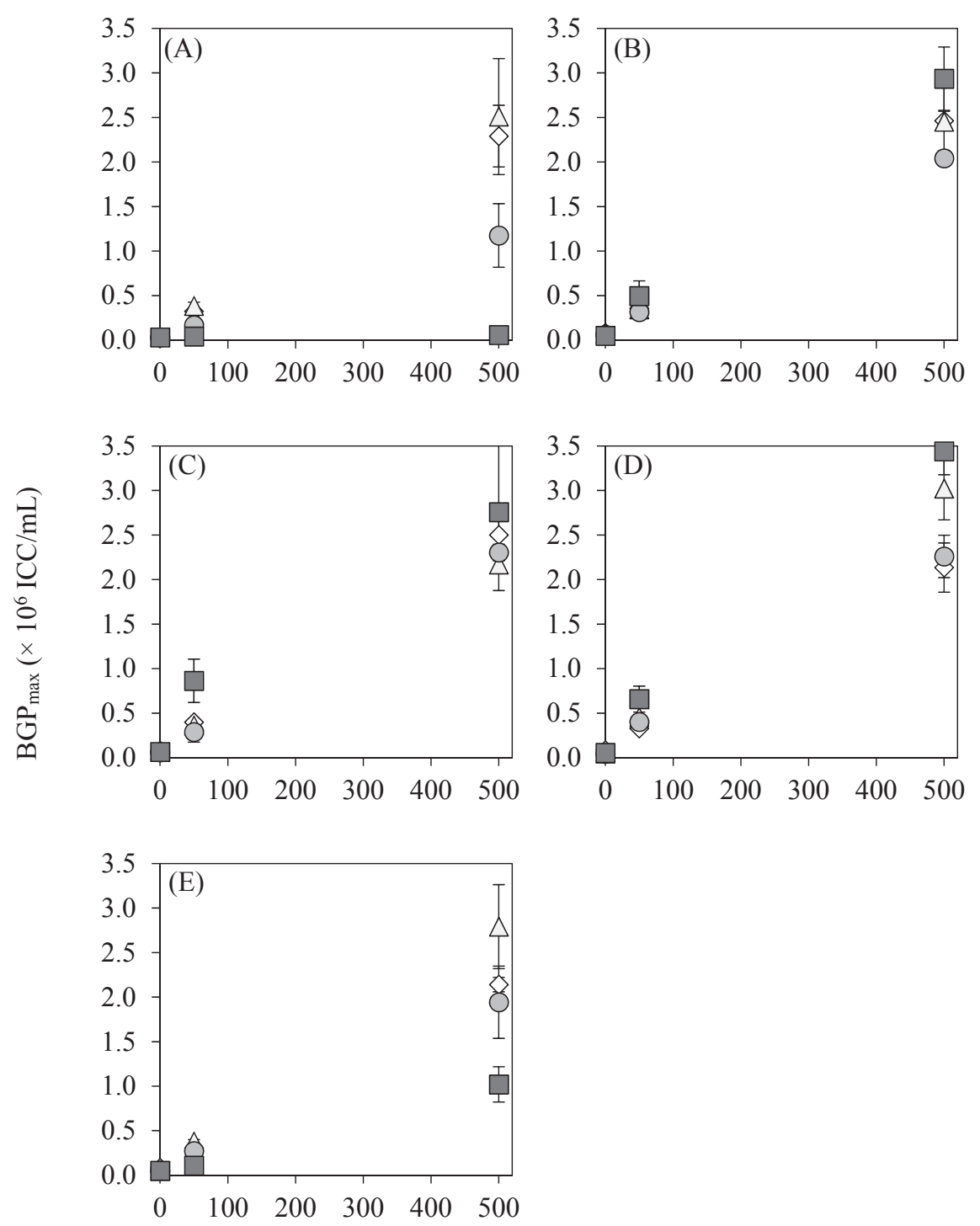

Carbon $(\mu \mathrm{g}-\mathrm{C} / \mathrm{L})$

Figure 3.6. Maximum bacterial growth potential $\left(\mathrm{BGP}_{\max } ; 20\right.$ days at $\left.30{ }^{\circ} \mathrm{C}\right)$ on different carbon sources. Samples of lab-remineralised RO permeate (lab-Remin) were either noninoculated (indigenous bacteria of RO permeate, A) or inoculated with bacteria originating from site-remineralised RO permeate (site-Remin, B), activated carbon filtrate (ACF, C), conventionally treated water (CTW, D), or anaerobic groundwater (AGW, E). Error bars represent the measurement variations of 3 separate tests, with triplicate vials per test (in total, $\mathrm{n}=9$ ). 
Measuring bacterial growth potential of ultra-low nutrient drinking water produced by reverse osmosis: Effect of sample pre-treatment and bacterial inoculum

Regarding the growth on natural DOC $(2.75 \mathrm{mg}-\mathrm{C} / \mathrm{L})$ prepared from the pasteurised RO concentrate, the results revealed that the type of bacterial inoculum also significantly $(P<$ 0.05 ) influenced the growth (Figure 3.8). The highest growth in lab-Remin was observed when natural bacterial inocula originating from CTW $\left(350 \pm 15 \times 10^{3} \mathrm{ICC} / \mathrm{mL}\right), \mathrm{ACF}(300$ $\left.\pm 45 \times 10^{3} \mathrm{ICC} / \mathrm{mL}\right)$, and AGW $\left(270 \pm 35 \times 10^{3} \mathrm{ICC} / \mathrm{mL}\right)$ were used. Lower growth was observed with site-Remin inoculum $\left(124 \pm 8 \times 10^{3} \mathrm{ICC} / \mathrm{mL}\right)$, and the indigenous bacteria of RO permeate (i.e., no inoculation, $87 \pm 4 \times 10^{3} \mathrm{ICC} / \mathrm{mL}$ ).
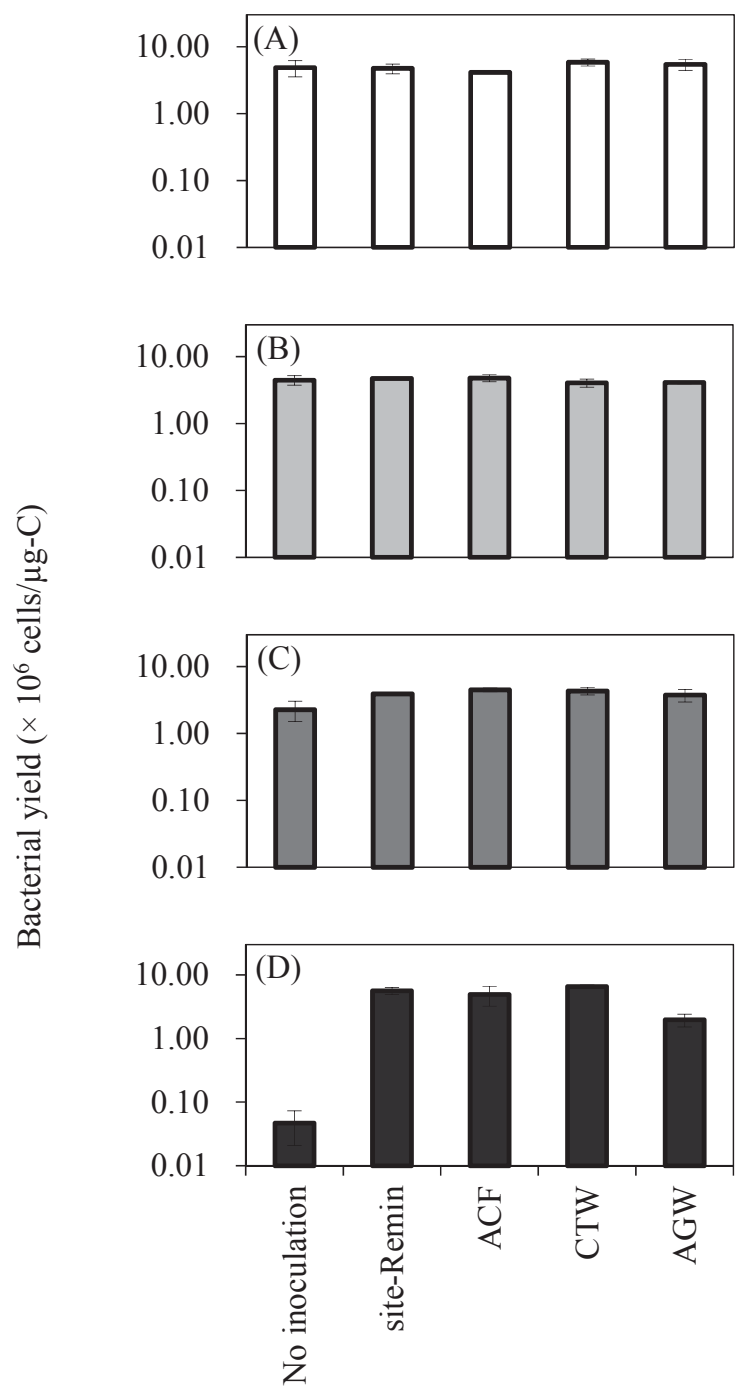

Figure 3.7. Bacterial yield in lab-Remin without inoculation or after inoculating with natural bacteria originating from: site-Remin, ACF, CTW, and AGW. Four sources of organic carbon were used: glucose (A), acetate (B), laminarin (C), and gelatin (D). Error bars represent the measurement variations of 3 separate tests, with triplicate vials per test (in total, $n=9$ ). 
Measuring bacterial growth potential of ultra-low nutrient drinking water produced by reverse osmosis: Effect of sample pre-treatment and bacterial inoculum

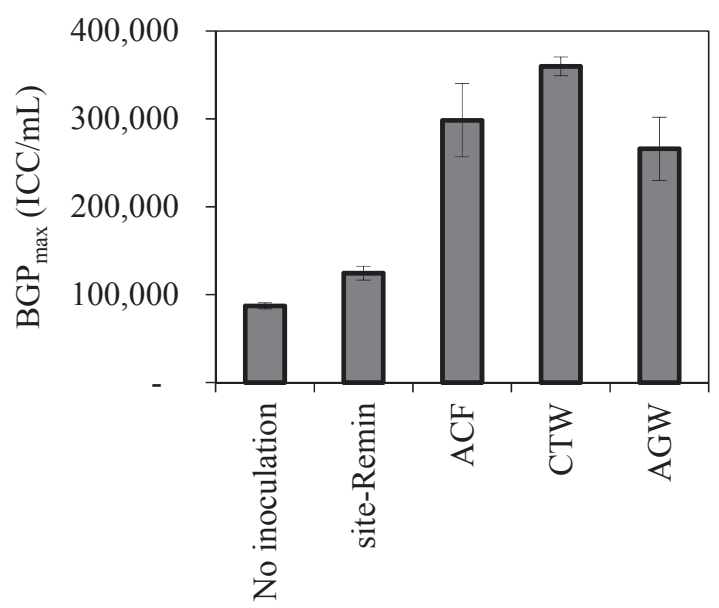

Figure 3.8. Maximum bacterial growth potential $\left(\mathrm{BGP}_{\max } ; 20\right.$ days at $\left.30{ }^{\circ} \mathrm{C}\right)$ of labremineralised RO permeate (lab-Remin) without inoculation or after inoculating with natural bacteria originating from: site-remineralised RO permeate (site-Remin), activated carbon filtrate (ACF), conventionally treated water (CTW), and anaerobic groundwater (AGW). The growth was measured after the addition of natural DOC $(2.75 \mathrm{mg}-\mathrm{C} / \mathrm{L})$ originating from RO concentrate. Error bars represent the measurement variations of 3 separate tests, with triplicate vials per test (in total, $n=9$ ).

\subsubsection{Monitoring BGP of conventionally treated and RO-treated drinking water}

The initial intact cell count and BGP of lab-Remin, site-Remin, and CTW were monitored for a period of 2 years (Figure 3.9). The results demonstrated superior performance of the RO-based treatment line, where the initial cell count of lab-Remin $\left(<10^{3} \mathrm{ICC} / \mathrm{mL}\right)$ and siteRemin $\left(25 \times 10^{3}-200 \times 10^{3} \mathrm{ICC} / \mathrm{mL}\right)$ were systematically lower than that of CTW $(400 \times$ $10^{3}-600 \times 10^{3} \mathrm{ICC} / \mathrm{mL}$ ). Similarly, the BGP was subsequently reduced by $>75 \%$ with the RO-based treatment line compared with the conventional one, where no pronounced seasonal variations were observed and the BGP was stable around $35 \times 10^{3}-60 \times 10^{3}, 90$ $\times 10^{3}-150 \times 10^{3}$, and $500 \times 10^{3}-700 \times 10^{3} \mathrm{ICC} / \mathrm{mL}$ for lab-Remin, site-Remin, and CTW, respectively. 
Measuring bacterial growth potential of ultra-low nutrient drinking water produced by reverse osmosis: Effect of sample pre-treatment and bacterial inoculum
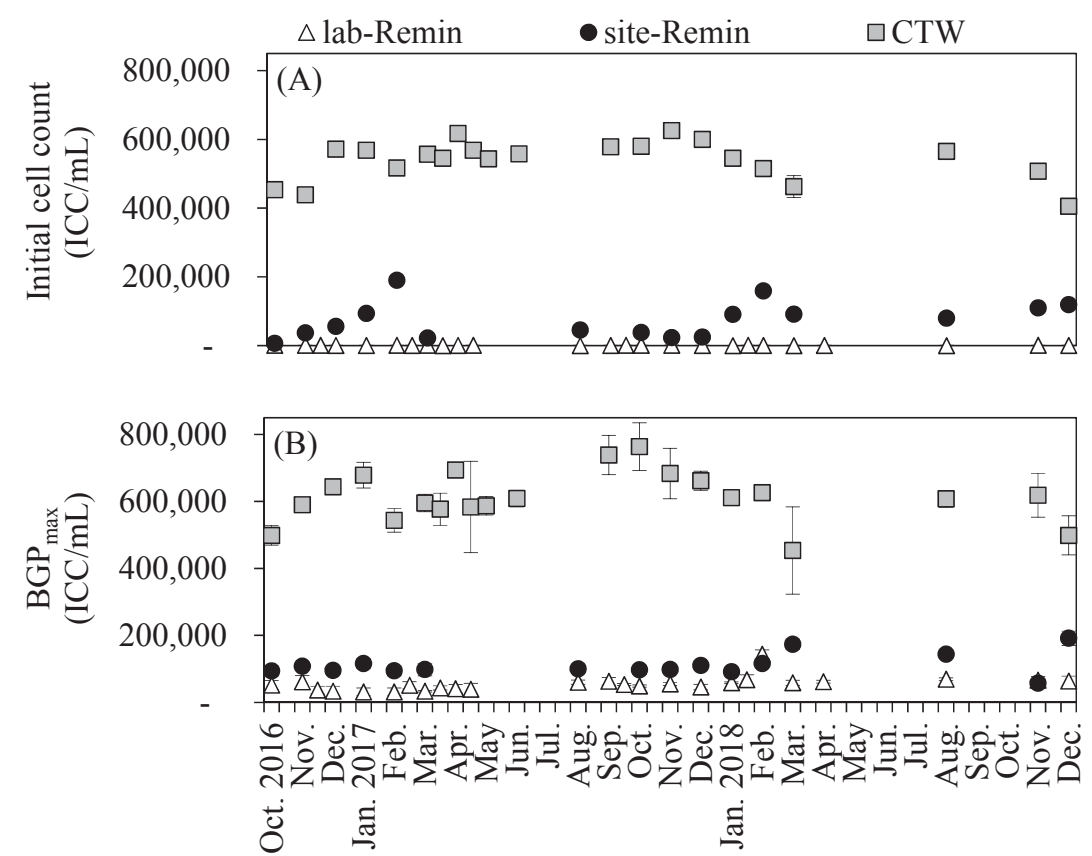

Figure 3.9. Initial intact cell count (A) and maximum bacterial growth potential (BGP $\left.\mathbf{m a x}_{\text {ax }}, \mathrm{B}\right)$ of lab-remineralised RO permeate (lab-Remin, the blank), site-remineralised RO permeate (site-Remin), and conventionally treated water (CTW). All samples were pasteurised $\left(70{ }^{\circ} \mathrm{C}\right.$ for $30 \mathrm{~min}$ ) and inoculated with CTW. Error bars represent the variations of triplicate measurements.

\subsection{Discussion}

This study focused on: assessing the effect of sample pre-treatment on the BGP of ultra-low nutrient water, and examining the ability of (remineralised) RO permeate bacteria to utilise readily available as well as complex organic carbon. Expressing the BGP results in the most appropriate way is essential to accurately interpret the test outcome, allowing for achieving the objectives of this study. Currently, the BGP results are expressed either as $\mathrm{BGP}_{\text {net }}$ for pre-treated (Vital et al., 2010; Park et al., 2016) and non-pre-treated (i.e., direct incubation) (Prest et al., 2016a; Nescerecka et al., 2018) samples, or as BGP $\max$ (Joret et al., 1991; Percherancier et al., 1996; Sousi et al., 2018).

The results of the present study suggest that BGP $\max$ gives a better representation of the BGP of water, since the effect of initial cell count is ruled out. On the other hand, several BGP net values were obtained for the same water type due to the variation in the initial cell count even though the nutrient content did not change, where this phenomenon was also observed 
Measuring bacterial growth potential of ultra-low nutrient drinking water produced by reverse osmosis: Effect of sample pre-treatment and bacterial inoculum

for pure bacterial cultures that reached the stationary growth phase (Fujikawa et al., 2004; Pla et al., 2015). Therefore, BGP $\max$ reflects the total number of bacteria that can be maintained in water depending on the total nutrients available, part of which is utilised to maintain the initial bacteria and the remaining part is used for producing new bacteria. Only the latter part is considered when reporting $\mathrm{BGP}_{\text {net. }} \mathrm{BGP}_{\text {net }}$ of directly incubated samples (Prest et al., 2016a; Nescerecka et al., 2018) is relevant to predict the extent of bacterial growth that could occur in water distribution systems (Prest et al., 2016b). However, BGP net may be misleading when comparing the BGP of water types that are different in initial cell count and nutrient content. For instance, the comparable BGP net $\left(50 \times 10^{3}-100 \times 10^{3}\right.$ $\mathrm{ICC} / \mathrm{mL}$ ) of directly incubated conventionally treated water $(\mathrm{CTW})$ and RO-treated water (site-Remin) might indicate a similar degree of biological stability, whereas the organic nutrients were much lower in the case of site-Remin.

Based on the previous discussion, reporting both $\mathrm{BGP}_{\max }$ (after pre-treatment) and the initial cell count (before pre-treatment) may provide more information about the BGP of water: $\mathrm{BGP}_{\max }$ is linked to the total growth-promoting nutrients, and the extent of bacterial growth during distribution can be estimated based on the difference between BGP $\max$ and the initial cell count. Lastly, it could be argued that $\mathrm{BGP}_{\max }$ does not reflect the literal meaning of the test name (i.e., bacterial growth potential, BGP) because it does not include only the new cells produced (i.e., growth), but also the cells initially present in water. Therefore, adjusting the test name might be considered in the future.

\subsubsection{Effect of sample pre-treatment on BGP}

Although pasteurisation is used in many bioassays for assessing the biological stability of drinking water (van der Kooij and Hijnen, 1984; Sack et al., 2011; Park et al., 2016; Sousi et al., 2018), there is still a knowledge gap regarding its potential effect on the BGP of water. The comparable BGP $\max$ of the pasteurised and non-pre-treated (the control) water samples suggests that pasteurisation does not lead to significant changes in the concentration of organic compounds available for bacterial consumption. This was observed in this study for the different types of water, i.e., conventional drinking water (CTW) containing relatively high nutrients and water produced by RO treatment (site-Remin and lab-Remin) containing ultra-low nutrients, which is in line with previous findings (Sousi et al., 2018). DOC and its fractions (characterised using LC-OCD) did not significantly change after pasteurisation, even for the biodegradable part of DOC such as biopolymers and humic substances, which is in agreement with the BGP results. However, the LC-OCD characterisation could not explain the considerable increase in $\mathrm{BGP}_{\max }$ with the other pre-treatments (i.e., autoclaving for CTW and 0.22- $\mu \mathrm{m}$ filtration for lab-Remin), where the level of biodegradable DOC remained unchanged compared with non-pre-treated samples. In addition, the weak correlation between BGP $\max$ and AOC concentration can be attributed to the different nature of each test. For instance, the increase in AOC concentration in the pasteurised and 
Measuring bacterial growth potential of ultra-low nutrient drinking water produced by reverse osmosis: Effect of sample pre-treatment and bacterial inoculum

autoclaved CTW was comparable despite the large difference in $\mathrm{BGP}_{\max }$, indicating that some biodegradable compounds formed during autoclaving could not be consumed by the specific bacterial strains used in the AOC (P17/NOX) test unlike the natural bacterial communities used in the BGP bioassay (Hammes and Egli, 2005; Ross et al., 2013). Moreover, the slight increase $(1 \mu \mathrm{g} / \mathrm{L} \mathrm{Ac-C})$ in AOC concentration after pasteurising labRemin and site-Remin might be insignificant to be observed with the BGP test based on cell count, where low AOC concentrations did not lead to significant bacterial growth in drinking water (van der Kooij, 1992; Wang et al., 2014).

The systematic increase in BGP $\max$ of the autoclaved CTW samples (75-85\%) may be attributed to their relatively high nutrients, which increases the chance of nutrient denaturing, and/or to the autoclaving process that can convert the large DOC molecules to more biodegradable compounds (Servais et al., 1987). On the other hand, the considerable increase $(140-320 \%)$ in $\mathrm{BGP}_{\max }$ of ultra-low nutrient water (i.e., RO-treated water) pretreated by $0.22-\mu \mathrm{m}$ filtration was likely due to the leaching of biodegradable compounds from the filters (Khan and Subramania-Pillai, 2006), despite the intensive cleaning before using. The effect of filtration was exclusive for ultra-low nutrient water owing to the high sensitivity of such water even to slight leaching, whereas no measurable effect of filtration was observed for CTW that has a relatively higher nutrient content. Therefore, BGP bioassays based on pre-treatment by filtration may lead to misleading results for ultra-low nutrient water such as remineralised RO permeate, whereas those bioassays can still be applied for waters with rather high organic nutrients such as those included in the study of Farhat et al. (2018). As a result, pasteurisation is a suitable pre-treatment for ultra-low nutrient water as well as conventional drinking water with a relatively higher nutrient content.

\subsubsection{The ability of bacteria originating from (remineralised) RO permeate to utilise organic carbon}

Several water types have been used for the addition of natural bacterial inocula, including activated carbon filtrate, tap water, bottled water, and raw water (Hammes and Egli, 2005; Park et al., 2016; Prest et al., 2016a; Nescerecka et al., 2018). In addition to those inoculum types, this study examined the ability of bacteria naturally present in (remineralised) RO permeate to utilise organic carbon with various molecular characteristics. The results clearly demonstrated that the readily available organic carbon of acetate or glucose was effectively consumed by (remineralised) RO permeate bacteria, despite the very low cell count and the potentially limited number of bacterial species (especially in lab-Remin) (Belila et al., 2016). These results indicate that (remineralised) RO permeate bacteria possess the metabolic pathways to extract energy from glucose and acetate, which are commonly present in several bacterial species (Gray et al., 1966; Berg et al., 2002; Karakashev et al., 2006). The small molecular size of glucose and acetate (belong to monosaccharides), and 
Measuring bacterial growth potential of ultra-low nutrient drinking water produced by reverse osmosis: Effect of sample pre-treatment and bacterial inoculum

the possibility to convert them into energy by a broader range of bacteria may be the reasons that lab-Remin and site-Remin bacteria were able to consume it as effectively as the other bacterial inocula. The average yields considering all inocula on glucose $\left(5.00 \pm 0.65 \times 10^{6}\right.$ cells $/ \mu \mathrm{g}-\mathrm{C})$ and acetate $\left(4.45 \pm 0.35 \times 10^{6} \mathrm{cells} / \mu \mathrm{g}-\mathrm{C}\right)$ were in line with the reported values (e.g., acetate, $1 \times 10^{6}$ to $1 \times 10^{7}$ cells $/ \mu$ g-C) for natural bacteria (Hammes and Egli, 2005; Prest et al., 2016a; Farhat et al., 2018) or pure strains (van der Kooij et al., 1982).

In contrast to glucose and acetate, variations in bacterial growth between the studied inocula were observed when complex organic carbon was used. Laminarin is a polysaccharide of glucose, consisting of polymers varying in the molecular size $(<5,000 \mathrm{Da})$ (Percival and Ross, 1951; Smith et al., 2011). These characteristics of laminarin indicate that the indigenous RO permeate bacteria (i.e., in non-inoculated lab-Remin) lack the enzymes required for the extracellular hydrolysis of high molecular weight (HMW) polymers present in the laminarin mixture to glucose (Boraston et al., 2004; Hrmova and Fincher, 2009). Hence, they were able to grow only on the low molecular weight (LMW) polymers in the laminarin mixture. The similar yields on glucose and laminarin for all the other inocula (i.e., site-Remin, ACF, CTW, and AGW) suggests that they contain more diverse consortia that are able to completely hydrolyse laminarin to glucose and subsequently to energy molecules. The degradation of gelatin indicates the presence of extracellular enzymes (e.g., gelatinase) that are produced by certain bacterial species to liquefy gelatin (Vroman and Tighzert, 2009). However, the indigenous RO permeate bacteria (i.e., in non-inoculated labRemin) seem to completely lack such enzymes, as the growth was negligible compared with the other inocula. Although aerobic (Stewart and Halvorson, 1953; Shiba and Simidu, 1982; Narayan et al., 2008) and, to a lesser extent, anaerobic bacteria (Hoeffler, 1977; Whaley et al., 1982; Bruns et al., 2001) are capable of hydrolysing gelatin, the results of this study suggest that the aerobic bacteria are more effective in degrading the complex gelatin (40,000-50,000 Da (Sack et al., 2014)) into smaller compounds (e.g., amino acids) that can be further utilised for cell maintenance and proliferation. This higher effectiveness was demonstrated in previous studies (Knowles and Smith, 1970; Tran and Unden, 1998; Trchounian et al., 1998), where aerobes obtained more energy from gelatin compared with anaerobes.

Taken together, the results suggest that BGP on the model carbon (glucose, acetate, laminarin, and gelatin) is dependent on: the natural bacterial inoculum used (i.e., the composition of bacterial communities); and the organic carbon characteristics (i.e., the complexity and molecular size). The aerobic bacterial consortia originating from treated water showed the highest yield factors for all the carbon sources. However, each carbon source may promote the growth of different aerobic bacterial species, as shown elsewhere (Sack et al., 2014) for biofilm grown in drinking water installations, where gelatin was utilised by a broader range of bacterial strains compared with polysaccharides. Therefore, further research would be needed to investigate this phenomenon for bulk water bacteria. 
Measuring bacterial growth potential of ultra-low nutrient drinking water produced by reverse osmosis: Effect of sample pre-treatment and bacterial inoculum

Regarding the bacterial growth on the natural DOC, the observed different growth for each inoculum type suggests that some bacterial strains are incapable of effectively utilising the organic carbon present naturally in water. A similar effect was demonstrated by Joret et al. (1991), where different pure bacterial strains inoculated separately in the same water type showed considerably different abilities to convert the biodegradable DOC to new cells. Therefore, the most likely reason for the results of this study is the limited number of bacterial strains, particularly in (remineralised) RO permeate, to utilise the HMW organic compounds that form the largest proportion of the natural DOC in fresh water (Amon and Benner, 1996; Regan et al., 2017). This explanation is in line with the results discussed above, where the growth of certain bacterial communities on HMW compounds of the model carbon was limited. The BGP of indigenous RO permeate bacteria (i.e., in noninoculated lab-Remin), that could efficiently utilise LMW compounds, on the natural DOC was only $25 \%$ of that of the aerobic ACF and CTW bacteria, that could efficiently utilise LMW and HMW compounds. This suggests that the natural DOC contains at least $75 \%$ of HMW compounds, as previously observed by Amon and Benner (1996). Furthermore, the growth on the natural DOC was equivalent to AOC concentrations of 40-70 $\mu \mathrm{g} / \mathrm{L} \mathrm{Ac-C}$ (calculated using the yield obtained in this study), forming $1.5-2.7 \%$ of the natural DOC $(\sim 2.75 \mathrm{mg}-\mathrm{C} / \mathrm{L})$. This ratio is consistent with previous findings for various water types (van der Kooij et al., 1989; Hu et al., 1999; Hem and Efraimsen, 2001; Shi-Hu et al., 2008; Prest et al., 2016b). Understanding the ability of bacteria to utilise HMW compounds is essential, since such compounds form a significant fraction of DOC in drinking water. Moreover, the actual bacterial growth in distribution systems was found to be strongly influenced by the concentration of HMW compounds, rather than easily biodegradable substances (Hijnen et al., 2018).

Based on the previous discussion, an aerobic bacterial inoculum originating from treated water, such as activated carbon filtrate or finished conventionally treated water, seems to effectively consume the available organic carbon resulting in reliable BGP outcomes.

\subsubsection{Practical implications}

The optimised BGP bioassay for ultra-low nutrient water was applied for RO-treated drinking water. The results confirmed the superior effectiveness of RO treatment in reducing

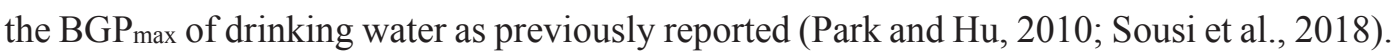
Moreover, the stable $\mathrm{BGP}_{\max }$ over the seasons can be attributed to the small variation in nutrients of the source groundwater (Nescerecka et al., 2018). RO treatment is a promising technology to produce drinking water with a high degree of biological stability, which highlights the need for sensitive bioassays to measure the BGP. 
Measuring bacterial growth potential of ultra-low nutrient drinking water produced by reverse osmosis: Effect of sample pre-treatment and bacterial inoculum

\subsection{Conclusions}

The optimised BGP bioassay for ultra-low nutrient water considers:

- Expressing the BGP results as the maximum bacterial growth obtained during the incubation period after pre-treatment (BGP $\max$ ). Moreover, reporting the initial cell count (before pre-treatment) together with $\mathrm{BGP}_{\max }$ provides more information about the predicted bacterial growth during water distribution.

- Pre-treatment of water samples by pasteurisation, where no effect on the BGP $\max$ was observed for ultra-low nutrient water (remineralised RO permeate) and conventional drinking water. On the other hand, pre-treatment by autoclaving and $0.22-\mu \mathrm{m}$ membrane filtration resulted in a considerable increase in BGP $\max$ for some water types, where the filtration effect was exclusively observed for ultra-low nutrient water.

- Not using (remineralised) RO permeate bacteria as inoculum, where significant limitations in their ability to utilise complex organic carbon (laminarin, gelatin, and natural DOC) were observed. Instead, aerobic bacteria of conventional drinking water should be used to ensure utilising the majority of organic compounds, and thus, obtaining a reliable estimation of the BGP of water.

By using the optimised BGP bioassay over a 2-year period, the $\mathrm{BGP}_{\max }$ of drinking water was significantly reduced $(>75 \%)$ by applying RO-based treatment to produce ultra-low nutrient water that can limit bacterial growth. 



\section{4}

\section{MULTI-PARAMETRIC ASSESSMENT OF BIOLOGICAL STABILITY OF DRINKING WATER PRODUCED FROM GROUNDWATER: REVERSE OSMOSIS VS. CONVENTIONAL TREATMENT}

This chapter is based on the following publication:

Sousi, M., Liu, G., Salinas-Rodriguez, S.G., Chen, L., Dusseldorp, J., Wessels, P., Schippers, J.C., Kennedy, M.D., van der Meer, W., 2020. Multi-parametric assessment of biological stability of drinking water produced from groundwater: Reverse osmosis vs. conventional treatment. Water Research 186 , 116317. 
Multi-parametric assessment of biological stability of drinking water produced from groundwater: reverse osmosis vs. conventional treatment

\begin{abstract}
Although water produced by reverse osmosis (RO) filtration has low bacterial growth potential (BGP), post-treatment of RO permeate, which is necessary prior to distribution and human consumption, needs to be examined because of the potential re-introduction of nutrients/contaminants. In this study, drinking water produced from anaerobic groundwater by RO and post-treatment (ion exchange, calcite contactors, and aeration) was compared with that produced by conventional treatment comprising (dry) sand filtration, pellet softening, rapid sand filtration, activated carbon filtration, and UV disinfection. The multiparametric assessment of biological stability included bacterial quantification, nutrient concentration and composition as well as bacterial community composition and diversity. Results showed that RO permeate remineralised in the laboratory has an extremely low BGP $\left(50 \pm 12 \times 10^{3} \mathrm{ICC} / \mathrm{mL}\right)$, which increased to $130 \pm 10 \times 10^{3} \mathrm{ICC} / \mathrm{mL}$ after site post-treatment. Despite the negative impact of post-treatment, the BGP of the finished RO-treated water was $>75 \%$ lower than that of conventionally treated water. Organic carbon limited bacterial growth in both RO-treated and conventionally treated waters. The increased BGP in ROtreated water was caused by the re-introduction of nutrients during post-treatment. Similarly, OTUs introduced during post-treatment, assigned to the phyla of Proteobacteria and Bacteroidetes (75-85\%), were not present in the source groundwater. Conversely, conventionally treated water shared some OTUs with the source groundwater. It is clear that RO-based treatment achieved an extremely low BGP, which can be further improved by optimising post-treatment, such as using high purity calcite. The multiparametric approach adopted in this study can offer insight into growth characteristics including limiting nutrients (why) and dominating genera growing (who), which is essential to manage microbiological water quality in water treatment and distribution systems.
\end{abstract}

\title{
4.1 Introduction
}

Water utilities are aiming at producing biologically safe and stable drinking water, i.e., water that does not promote excessive bacterial growth during distribution. To achieve that, source water undergoes different treatment processes to remove bacteria and growth-promoting nutrients. The multi-barrier treatment approach is especially needed in the Netherlands, where chlorine is neither used for primary disinfection nor for maintaining disinfectant residual in the distribution network. Groundwater accounts for about two-thirds of total drinking water in the Netherlands (van der Kooij and Veenendaal, 2014; Vewin, 2017), and typically contains high concentrations of methane and inorganic compounds (Prest et al., 2016b). Groundwater is conventionally treated by aeration, rapid sand filtration, activated carbon filtration, and sometimes UV disinfection before pumping the water into distribution systems (de Vet et al., 2010; van der Kooij et al., 2017). Though drinking water of high quality is produced and supplied in the Netherlands, the assimilable organic carbon (AOC) 
Multi-parametric assessment of biological stability of drinking water produced from groundwater: reverse osmosis vs. conventional treatment

may occasionally be higher than the biological stability guideline of $10 \mu \mathrm{g} / \mathrm{L} \mathrm{Ac}-\mathrm{C}$ (van der Wielen and van der Kooij, 2010).

To ensure the best microbiological water quality (AOC $\sim 1 \mu \mathrm{g} / \mathrm{L}$ Ac-C), Oasen drinking water utility is constructing a treatment plant based on reverse osmosis (RO) filtration, which can efficiently reduce cell count, AOC, and bacterial growth potential (BGP) (Escobar et al., 2000; Park and Hu, 2010; Dixon et al., 2012; Thayanukul et al., 2013). One of the clear advantages of applying RO in drinking water treatment is that it can achieve a significant reduction in biofilm formation compared with conventional treatment, which controls the growth of L. pneumophila to a large extent (Learbuch et al., 2019). To comply with drinking water regulations, post-treatment of RO permeate is necessary for remineralisation (e.g., calcium and magnesium), maintaining chemical stability, and improving taste (Vingerhoeds et al., 2016). However, the post-treatment steps are likely to re-contaminate RO permeate by introducing organic and inorganic components, such as the observed increase in BGP caused by the re-introduction of growth-promoting nutrients in the permeate (Sousi et al., 2018).

Until now, the potential negative effects of post-treatment on biological stability and its control strategies are still poorly documented. Several methodologies and protocols have been developed for the assessment of drinking water biological stability, including measuring the nutrients as AOC and biodegradable organic carbon (BDOC), and enumerating bacteria as BGP and biofilm formation potential (BFP). Recently, bacterial community profiling has been introduced as a complementary tool, which elevates the assessment of biological stability to include both quantity and community aspects. Lautenschlager et al. (2013) and Prest et al. (2014) applied a multi-parametric approach that combined flow cytometric cell counting and 16S rRNA sequencing, which examined different aspects of microbiological water quality and captured the changes that cannot be reflected by single parameter studies. As the type and composition of nutrients are important for both bacterial growth and shaping the bacterial community (Elhadidy et al., 2016; Nescerecka et al., 2018), including a detailed analysis of carbon, phosphate, and nitrogen fractions in the multi-parametric approach is necessary to understand the driving force for bacterial growth. Such an integral multi-parametric approach will be especially powerful for comparing treatment plant performance, and/or diagnosing problems related to bacterial growth in drinking water.

The objective of this study was to conduct a multi-parametric comparison of biological stability of drinking water produced from anaerobic groundwater by RO-based treatment (RO filtration and post-treatment) and conventional treatment. The integral comparison includes the changes in bacterial quantification and growth potential, nutrient concentration and composition, and the bacterial community composition and diversity across steps in the different treatment lines, based on which the treatment performance was evaluated and recommendations were given on optimising the quality of RO-treated drinking water. 
Multi-parametric assessment of biological stability of drinking water produced from groundwater: reverse osmosis vs. conventional treatment

\subsection{Materials and methods}

\subsubsection{Water samples}

The Kamerik drinking water treatment plant (Oasen Drinking Water Company, Gouda, Netherlands) currently produces $340 \mathrm{~m}^{3} / \mathrm{h}$ of drinking water from anaerobic groundwater (AGW) by conventional water treatment processes, which are given in Figure 4.1A in the following order: spray aeration on the surface of rapid sand filters (so-called dry sand filtration, DSF), tower aeration, pellet softening (SOF), carry-over submerged rapid sand filtration (RSF), granular activated carbon filtration (ACF), and UV disinfection (UVD) before storing the conventionally treated water $(\mathrm{CTW})$ in the clean water reservoir.

Installed in parallel for research purposes, a pilot-scale advanced treatment line with a capacity of $7 \mathrm{~m}^{3} / \mathrm{h}$ treats the same source water with the following processes (Figure 4.1B): anaerobic RO filtration (RO) with a total recovery of $75 \%$, followed by post-treatment comprising anaerobic ion exchange (IEX) to remove residual ammonium, remineralisation using anaerobic calcite contactors (CC) to correct the calcium and bicarbonate concentrations to the required level $\left(40 \mathrm{mg} / \mathrm{L} \mathrm{Ca}^{2+}, 122 \mathrm{mg} / \mathrm{L} \mathrm{HCO}_{3}{ }^{-}\right)$, magnesium dosing $\left(\mathrm{MgCl}_{2}, 4 \mathrm{mg} / \mathrm{L} \mathrm{Mg}^{2+}\right)$, and tower aeration for the introduction of oxygen and the removal of methane and excess carbon dioxide. The finished drinking water after RO filtration and all post-treatment processes is denoted as site-Remin and has a final $\mathrm{pH}$ of $7.8 \pm 0.2$. The full treatment details are given in Table 4.1.

Water samples were collected after each treatment step in both the conventional and RObased treatment lines. The main sampling campaign was conducted in March 2019 where all the analyses mentioned in the following section were performed. An additional campaign was conducted in May 2019 where only intact cell count (ICC) and ATP analyses were performed.

\subsubsection{The multi-parametric comparison components}

i. Intact cell count (ICC): ICC was measured using flow cytometry (BD Accuri C6 ${ }^{\circledR}$ FCM, BD Biosciences, Belgium) coupled with DNA staining as previously described by Prest et al. (2016a). In short, each sample (500 $\mu \mathrm{L}$ per replicate) was stained with $5 \mu \mathrm{L}$ of a mix of $\mathrm{SYBR}^{\circledR}$ Green I and propidium iodide stains and heated for 10 min before FCM measurement using similar settings and gating. The FCM detection limit is $10^{3} \mathrm{ICC} / \mathrm{mL}$, which was determined using ultrapure water (Milli$\mathrm{Q}^{\circledR}$ water, Merck Millipore). Moreover, the size of bacteria was classified between large and small using high and low nucleic acid (HNA and LNA) characteristics obtained by the FCM (Wang et al., 2009).

ii. Adenosine triphosphate (ATP): Microbial intra-cellular ATP was measured according to the filtration-based method described by Abushaban et al. (2019) using 
Multi-parametric assessment of biological stability of drinking water produced from groundwater: reverse osmosis vs. conventional treatment

the Water-Glo testing kit (lysis reagent and detection reagent) and GloMax ${ }^{\circledR}-20 / 20$ Luminometer (Promega Corp., USA). The detection limit is $0.1 \mathrm{ng} \mathrm{ATP/L.}$

iii. Bacterial growth potential (BGP): BGP of water was measured according to Sousi et al. (2018). In short, samples were taken in AOC-free glassware, pre-treated by pasteurisation $\left(70{ }^{\circ} \mathrm{C}\right.$ for $\left.30 \mathrm{~min}\right)$ to remove indigenous bacteria, inoculated with a natural bacterial consortium $\left(\sim 10^{4} \mathrm{ICC} / \mathrm{mL}\right)$ originating from CTW freshly collected at each sampling campaign, distributed into three individual AOC-free vials (i.e., triplicate measurements per sample), incubated in the dark at $30{ }^{\circ} \mathrm{C}$, and lastly measured for ICC over a growth period of 3 weeks, commonly on day $0,1,3,6,8$, $10,13,16$, and 20 . The results were expressed as the maximum cell count obtained during the incubation period $\left(\mathrm{BGP}_{\max }\right)$.

The blank was prepared by adjusting the mineral content of RO permeate at the laboratory using chemical stock solutions with high purity: $\mathrm{NaHCO}_{3}$ (pH of 7.8 \pm 0.2 , $\left.122 \mathrm{mg} / \mathrm{L} \mathrm{HCO}_{3}{ }^{-}\right), \mathrm{CaCl}_{2}\left(40 \mathrm{mg} / \mathrm{L} \mathrm{Ca}^{2+}\right)$, and $\mathrm{MgCl}_{2}\left(4 \mathrm{mg} / \mathrm{L} \mathrm{Mg}^{2+}\right)$. The blank (laboratory-remineralised $\mathrm{RO}$ permeate) is denoted as lab-Remin, and was spiked with $\mathrm{KH}_{2} \mathrm{PO}_{4}\left(5 \mu \mathrm{g} / \mathrm{L} \mathrm{PO}_{4}-\mathrm{P}\right)$ and $\mathrm{KNO}_{3}(50 \mu \mathrm{g}-\mathrm{N} / \mathrm{L})$ to ensure that carbon was the growth-limiting nutrient, unless otherwise mentioned. Ion exchange effluent samples were also remineralised with the same concentration of $\mathrm{NaHCO}_{3}, \mathrm{CaCl}_{2}$, and $\mathrm{MgCl}_{2}$ to ensure that bacterial growth is not limited by minerals. It is worthwhile to mention that the BGP of anaerobic groundwater (AGW) might be underestimated because of the very high nutrient content (e.g., phosphate and humic substances), which might have formed complexes (e.g., with iron) when oxygen was introduced during the test, and thus, limiting the bioavailability of those nutrients.

iv. Bacterial growth-promoting nutrients: Each water sample was analysed for organic carbon $(\mathrm{C})$ and phosphate $\left(\mathrm{PO}_{4}-\mathrm{P}\right)$ concentrations. Liquid chromatography - organic carbon detection (LC-OCD) analysis was performed at Het Waterlaboratorium (Haarlem, Netherlands) to measure the concentration of carbon fractions as described by Huber et al. (2011). The carbon fractions were distinguished based on their molecular weight (MW), and they are (from largest to smallest): biopolymers (proteins and polysaccharides), humic substances, building blocks, low molecular weight acids, and neutrals. The reporting limit of LC-OCD analysis is $100 \mu \mathrm{g}-\mathrm{C} / \mathrm{L}$ for biopolymers and $200 \mu \mathrm{g}-\mathrm{C} / \mathrm{L}$ for the other fractions.

Phosphate was measured at the Rijkswaterstaat laboratory (Lelystad, Netherlands) using the ascorbic acid method. The method implied the reaction of ammonium molybdate and antimony sodium tartrate with orthophosphate $\left(\mathrm{PO}_{4}{ }^{3-}\right)$ in an acidic medium to form a complex that was reduced to a blue-coloured compound by ascorbic acid. The blue colour intensity was measured within $30 \mathrm{~min}$ by spectrophotometry $(880 \mathrm{~nm})$, and then converted to phosphate using a calibration line. The detection limit was $0.3 \mu \mathrm{g} / \mathrm{L} \mathrm{PO}_{4}-\mathrm{P}$. 
Multi-parametric assessment of biological stability of drinking water produced from groundwater: reverse osmosis vs. conventional treatment
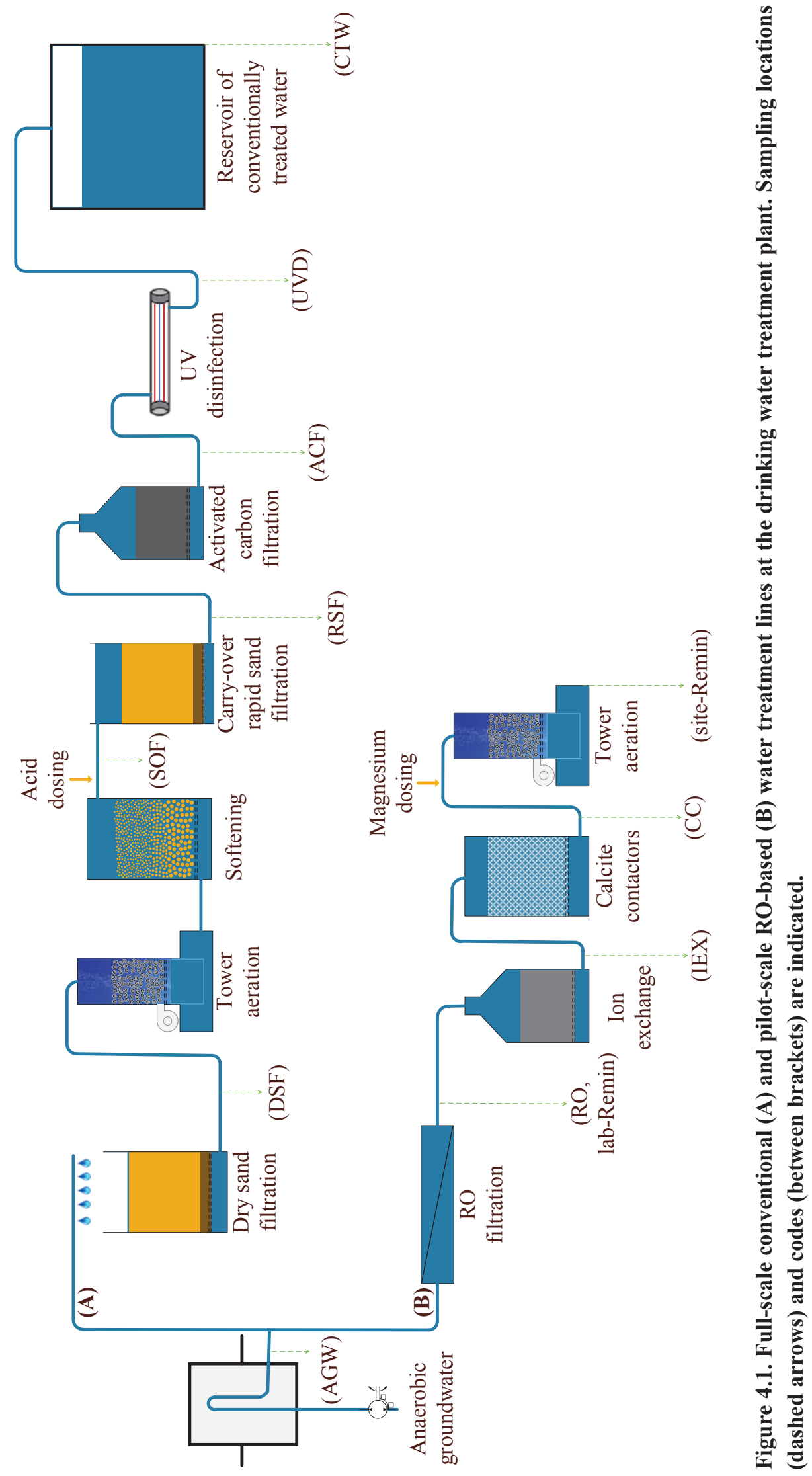
Multi-parametric assessment of biological stability of drinking water produced from groundwater: reverse osmosis vs. conventional treatment

Table 4.1. Detailed configurations of each step of the conventional and RO-based treatment lines at the drinking water treatment plant.

\begin{tabular}{|c|c|c|}
\hline & Treatment step & Details \\
\hline \multirow{20}{*}{ 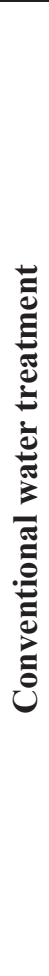 } & Dry sand filtration & 5 units ( $2 \mathrm{~m}$ bed height, $28 \mathrm{~m}^{2}$ surface area) \\
\hline & & Residence time $\sim 2.5-5 \mathrm{~min}$ \\
\hline & & Backwash: every $48 \mathrm{hrs}, 20 \mathrm{~min}$ cycle, $250 \mathrm{~m}^{3}$ volume \\
\hline & Tower aeration & 2 units ( $3 \mathrm{~m}$ height, $2.5 \mathrm{~m}^{2}$ surface area) \\
\hline & & Packing material: Pall-rings, $100 \mathrm{~mm}$ \\
\hline & & Co-current air flow \\
\hline & & $\mathrm{RQ} \sim 5-10$ \\
\hline & Pellet softening & 4 units ( $5 \mathrm{~m}$ height, $1.4 \mathrm{~m}^{2}$ surface area) \\
\hline & & Residence time $\sim 5.5 \mathrm{~min}$ \\
\hline & & Chemical: $\mathrm{NaOH}(\mathrm{pH} \sim 8.5-10)$ \\
\hline & & Sand grains: $0.15-0.40 \mathrm{~mm}$ \\
\hline & Submerged sand filtration & 3 units ( $2 \mathrm{~m}$ bed height, $18 \mathrm{~m}^{2}$ surface area) \\
\hline & & Hydraulic retention time $\sim 21 \mathrm{~min}$ \\
\hline & & Backwash: every $60 \mathrm{hrs}, 15 \mathrm{~min}$ cycle, $100 \mathrm{~m}^{3}$ volume \\
\hline & Granular activated carbon & 3 units ( $2 \mathrm{~m}$ bed height, $10 \mathrm{~m}^{2}$ surface area) \\
\hline & filtration & Residence time $\sim 12-15 \mathrm{~min}$ \\
\hline & & Regeneration: Every $37,500 \mathrm{~m}^{3} / \mathrm{m}^{3}$ bed volume \\
\hline & UV disinfection & Medium-pressure UV unit \\
\hline & & $\mathrm{UV}$ dose $=20 \mathrm{~mJ} / \mathrm{cm}^{2}$ \\
\hline & Clean water reservoir & Total volume $=7,430 \mathrm{~m}^{3}$ \\
\hline \multirow{14}{*}{ 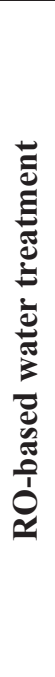 } & RO filtration & Total recovery $=75 \%$ \\
\hline & & 3 filtration stages: 9,3 , and 1 pressure vessels \\
\hline & & 3 elements per vessel \\
\hline & & Membrane surface area $=7.43 \mathrm{~m}^{2}$ \\
\hline & & Feed water pre-treatment: cartridge filter \\
\hline & Ion exchange & LEWATIT S 2568 synthetic cation resin \\
\hline & & Volume $=0.70 \mathrm{~m}^{3}$ \\
\hline & & Residence time $\sim 1.5-2.25 \mathrm{~min}$ \\
\hline & Remineralisation & calcite contactors \\
\hline & & $\mathrm{EBCT} \sim 15-20 \mathrm{~min}$ \\
\hline & Tower aeration & 2 units $\left(\right.$ Volume $\left.=1.24 \mathrm{~m}^{3}\right)$ \\
\hline & & Packing material: $38-8$ plastic Raflux-Rings, $15 \mathrm{~mm}$ \\
\hline & & Counter-current air flow \\
\hline & & Ratio of air to water flow (RQ) $\sim 10-15$ \\
\hline
\end{tabular}


Multi-parametric assessment of biological stability of drinking water produced from groundwater: reverse osmosis vs. conventional treatment

To identify bacterial growth-limiting nutrients, BGP of water samples was measured with the addition of different combinations of nutrients as previously described by Prest et al. (2016a), and shown in Table 4.2. The used nutrient stocks were carbon $(1.07 \mathrm{~g} / \mathrm{L}$ $\mathrm{C} 2 \mathrm{H} 3 \mathrm{NaO} 2)$, phosphate $(0.219 \mathrm{~g} / \mathrm{L} \mathrm{KH} 2 \mathrm{PO} 4)$, nitrogen $(3.61 \mathrm{~g} / \mathrm{L} \mathrm{KNO} 3)$, and a broth of trace elements $(5 \mathrm{mg} / \mathrm{L} \mathrm{CoCl} 2.6 \mathrm{H} 2 \mathrm{O}, 10 \mathrm{mg} / \mathrm{L} \mathrm{H} 3 \mathrm{BO} 3,10 \mathrm{mg} / \mathrm{L} \mathrm{CaSO} 4.5 \mathrm{H} 2 \mathrm{O}, 500 \mathrm{mg} / \mathrm{L}$ MnSO4.7H2O, $10 \mathrm{mg} / \mathrm{L} \mathrm{ZnSO} 4.7 \mathrm{H} 2 \mathrm{O}, 300 \mathrm{mg} / \mathrm{L}$ FeSO4.7H2O). Nutrients were added according to the ratio of $\mathrm{C}: \mathrm{N}: \mathrm{P}=100: 10: 1$ (Hammes and Egli, 2005). The blank (lab-Remin) and samples of the finished drinking water produced by the RO-based and conventional treatment lines (site-Remin and CTW, respectively) were tested.

Table 4.2. BGP test matrix to identify the bacterial growth-limiting nutrient in water samples.

\begin{tabular}{llllll}
\hline Test \# & $\mathbf{C}$ & $\mathbf{P}$ & $\mathbf{N}$ & $\mathbf{T E}^{*}$ & Investigation \\
& $\left(\mathbf{C}_{2} \mathbf{H}_{3} \mathbf{N a O}_{2}\right)$ & $\left(\mathbf{K H}_{2} \mathbf{P O}_{4}\right)$ & $\left(\mathbf{K N O}_{3}\right)$ & & \\
\hline 1 & - & - & - & - & actual BGP \\
2 & - & + & + & + & C-limited BGP \\
3 & + & - & + & + & P-limited BGP \\
4 & + & + & - & + & N-limited BGP \\
5 & + & + & + & - & TE-limited BGP \\
6 & + & + & + & + & positive control \\
\hline${ }^{*}$ Trace elements including $\mathrm{Co}, \mathrm{B}, \mathrm{S}, \mathrm{Mn}, \mathrm{Zn}$, and Fe
\end{tabular}

v. DNA extraction, sequencing, and data processing: Genomic DNA extraction was performed as previously described by Liu et al. (2018). In short, water samples (500 $\mathrm{mL}$, duplicate) were filtered using $0.22 \mu \mathrm{m}$ cellulose ester membranes (GPWP04700, Millipore, Ireland), and afterwards pre-treated using FastDNA Spin Kit for Soil (MP Biomedicals, Solon, OH, USA) as demonstrated in the instruction manual. Thereafter, 16S rRNA gene of the extracted genomic DNA was amplified, targeting the V3-V4 regions (a primer set of 341F: 5'CCTACGGGNGGCWGCAG-3' \& 785R: 5'-GACTACHVGGGTATCTAATCC3'). Illumina MiSeq platform (300 bp paired reads) was used for sequencing at BaseClear (Leiden, Netherlands), where the Illumina sequencing adaptors were appended to the 5 ' end. The sequencing data is available in the NCBI database (BioProject ID: PRJNA631515) and information about the sample origin is given in Table 4.3. 
Multi-parametric assessment of biological stability of drinking water produced from groundwater: reverse osmosis vs. conventional treatment

Table 4.3. Sample origin of each sequencing library submitted to NCBI database.

\begin{tabular}{ll}
\hline Object ID & Library ID \\
\hline 14871010 & anaerobic groundwater (AGW) 1 \\
14871011 & dry sand filtration (DSF) 1 \\
14871012 & softening (SOF) 1 \\
14871013 & rapid sand filtration (RSF) 1 \\
14871014 & activated carbon filtration (ACF) 1 \\
14871015 & UV disinfection (UVD) 1 \\
14871016 & conventionally treated water (CTW) 1 \\
14871017 & anaerobic groundwater (AGW) 2 \\
14871018 & dry sand filtration (DSF) 2 \\
14871019 & softening (SOF) 2 \\
14871020 & rapid sand filtration (RSF) 2 \\
14871021 & activated carbon filtration (ACF) 2 \\
14871022 & UV disinfection (UVD) 2 \\
14871023 & conventionally treated water (CTW) 2 \\
14871024 & RO filtration (RO) 1 \\
14871025 & ion exchange (IEX) 1 \\
14871026 & calcite contactors (CC) 1 \\
14871027 & finished RO-treated water (site-Remin) 1 \\
14871028 & RO filtration (RO) 2 \\
14871029 & ion exchange (IEX) 2 \\
14871030 & calcite contactors (CC) 2 \\
14871031 & finished RO-treated water (site-Remin) 2 \\
\hline
\end{tabular}

The sequences generated from the Illumina Miseq analysis of the 16S rRNA gene amplicons were processed (i.e., filtered, clustered, and taxonomically assigned and aligned) using the Quantitative Insights Into Microbial Ecology (QIIME2, v2018.6) pipeline with the default settings. Raw sequences were first processed using DADA2, including quality filtering, denoising, paired-end sequence merging, and chimera filtering. DADA2 generated unique amplicon sequence variants that were equivalent to $100 \%$ similarity operational taxonomic units (OTUs) in the conventional practice. In this publication, the term OTU is used for the purpose of simplicity. Taxonomy was assigned using q2-feature-classifier, customized for the primer set used in this study with Silva SSU database release 132. Multiple sequence alignment and phylogenetic tree construction were performed using the QIIME2 plugin q2-phylogeny. Alpha and beta diversity analyses were performed using the QIIME2 plugin q2-diversity. Weighted and unweighted UniFrac distance matrices were constructed from the phylogenetic tree (Liu et al., 2020). OTUs with relative abundance in the samples of $>0.5 \%$ were considered dominant. The absolute abundance of selected OTUs was calculated by multiplying their relative abundance by total cell count (TCC) obtained using FCM as proposed by Props et al. (2017). 
Multi-parametric assessment of biological stability of drinking water produced from groundwater: reverse osmosis vs. conventional treatment

\subsubsection{Statistical analysis}

The significance level of observed differences between samples was examined using Student's $t$-test and one-way analysis of variance (ANOVA) test after affirming the data normality (Q-Q plots, Chi-squared tests, and Kolmogorov-Smirnov tests). Canonical correspondence analysis (CCA) was carried out using XLSTAT (version 2019.4.2.63762) to investigate the influence of nutrients (LC-OCD fractions and phosphate) on microbiological parameters and community composition.

Principal coordinates analysis (PCoA) was conducted to visualise (dis)similarities of DNA sequences based on weighted UniFrac distance matrix, where the significance of (dis)similarities has been tested using permutational multivariate analysis of variance (PERMANOVA).

\subsection{Results}

\subsubsection{Intact cell count (ICC) and ATP concentration across treatment lines}

The trends in intact cell count (ICC) and ATP concentration across the conventional and RO-based treatment lines from two sampling campaigns are shown in Figure 4.2, respectively, where similar trends were observed except for concentrations in the source anaerobic groundwater (AGW). This section focuses on the results of the first sampling campaign. ICC and ATP concentration in the source anaerobic groundwater (AGW) were $215 \pm 40 \times 10^{3} \mathrm{ICC} / \mathrm{mL}$ and $\sim 0.5 \mathrm{ng} \mathrm{ATP} / \mathrm{L}$, which increased by a factor of 3 and 28 , respectively, after dry sand filtration (DSF) and softening (SOF) in the conventional treatment line where oxygen was introduced in the water. Thereafter, ICC decreased along the following conventional treatment units reaching $390 \pm 11 \times 10^{3} \mathrm{ICC} / \mathrm{mL}$ in the finished conventionally treated drinking water (CTW). This decrease in ICC was accompanied with a considerable decrease ( $70 \%)$ in ATP to the range of $4-5 \mathrm{ng}$ ATP/L after RSF and until the end of the conventional treatment (CTW).

In the RO-based treatment line, the ICC after RO filtration and ion exchange were lower than the FCM detection limit $\left(<10^{3} \mathrm{ICC} / \mathrm{mL},>99.6 \%\right.$ removal), which increased to $30 \pm 5$ $\times 10^{3} \mathrm{ICC} / \mathrm{mL}$ after calcite contactors (CC) and further to $90 \pm 1 \times 10^{3} \mathrm{ICC} / \mathrm{mL}$ after tower aeration (site-Remin). Similarly, ATP dropped below the detection limit after RO filtration $(<0.1 \mathrm{ng}$ ATP/L) and remained at this level after ion exchange (IEX). Thereafter, it increased after post-treatment with $\mathrm{CC}$ to $2 \mathrm{ng} \mathrm{ATP/L}$ and further to $7.5 \mathrm{ng} \mathrm{ATP} / \mathrm{L}$ in the finished ROtreated water after tower aeration (site-Remin).

The percentage of high nucleic acid bacteria (HNA bacteria) within ICC decreased across the conventional treatment from $60 \%$ after DSF and SOF to $40-45 \%$ after RSF and until 
Multi-parametric assessment of biological stability of drinking water produced from groundwater: reverse osmosis vs. conventional treatment

CTW. However, this percentage increased across the RO-based treatment and reached up to $85 \%$ in $\mathrm{CC}$ and site-Remin.

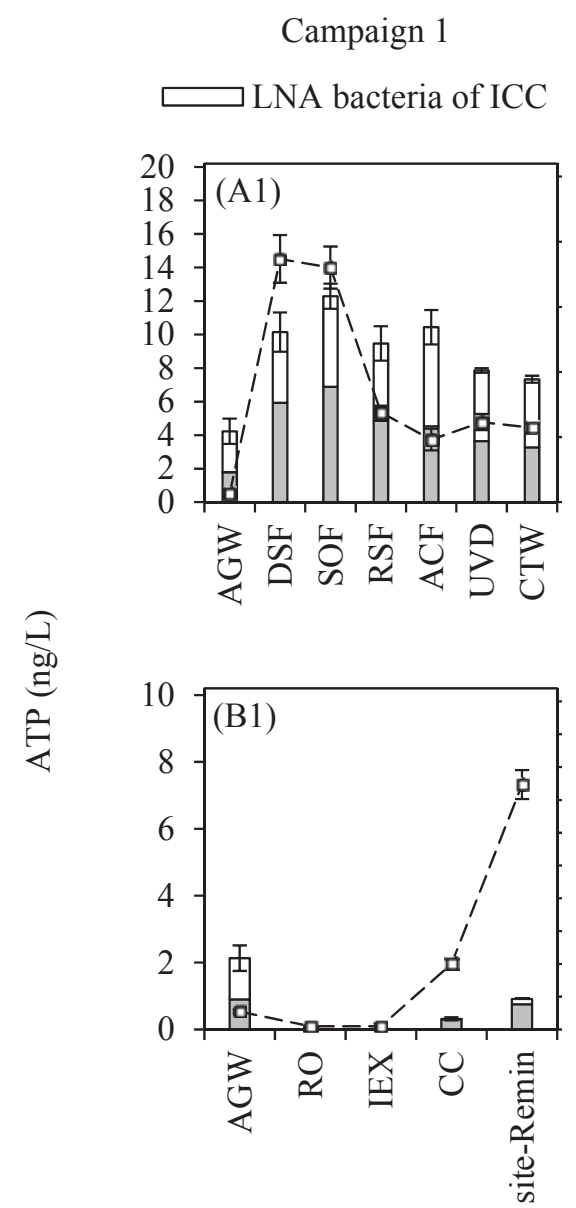

Campaign 2
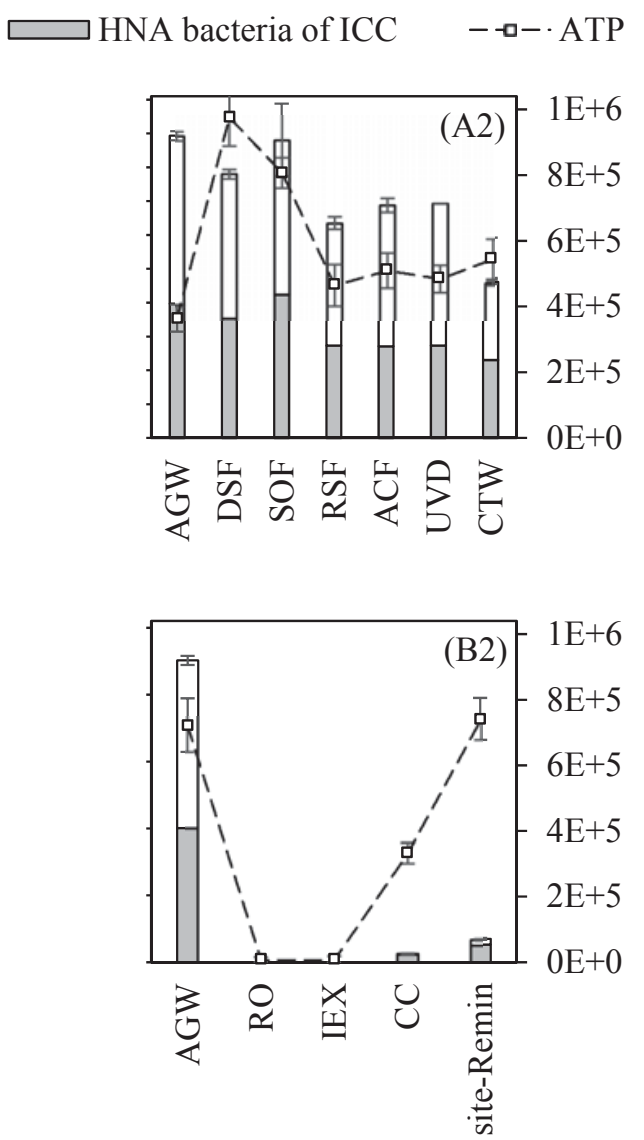

త్తి

Figure 4.2. ATP concentration, HNA bacterial count, LNA bacterial count, and intact cell count (HNA + LNA) of water samples after each treatment step in the conventional (A) and RO-based (B) treatment lines during two sampling campaigns. Error bars represent the standard deviation of triplicate measurements. 
Multi-parametric assessment of biological stability of drinking water produced from groundwater: reverse osmosis vs. conventional treatment

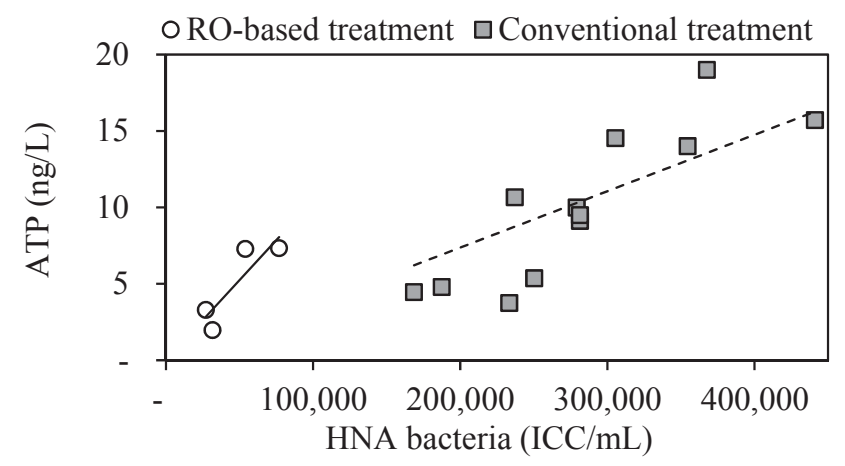

Figure 4.3. Correlation between HNA bacterial count and ATP concentration in conventional $\left(n=12, R^{2}=0.65\right)$ and $R O-b a s e d\left(n=4\right.$, excluding values below the detection limit, $\left.R^{2}=0.77\right)$ treatment.

A good correlation was found between HNA bacteria and ATP (Figure 4.3, $\mathrm{R}^{2}=0.77$, RObased treatment; $\mathrm{R}^{2}=0.65$, conventional treatment). Remarkably, ICC in RO-treated water was $>75 \%$ lower than that of conventionally treated water, whereas the contrary was observed for ATP, which resulted in a significantly higher $(P<0.05)$ ATP per cell value for RO-treated water than conventionally treated water (average of two sampling campaigns; $9.07 \times 10^{-17}$ vs. $1.71 \times 10^{-17} \mathrm{~g} \mathrm{ATP} /$ cell, Table 4.4), indicating different community composition between the two treatment lines.

Table 4.4. ATP per cell for conventionally treated and RO-treated water.

\begin{tabular}{|c|c|c|c|c|}
\hline \multirow{2}{*}{ Treatment line } & \multirow[t]{2}{*}{ Sample } & \multicolumn{3}{|c|}{$\times 10^{-17}$ g ATP/cell } \\
\hline & & Campaign 1 & Campaign 2 & Average \\
\hline Source water & AGW & 0.25 & 0.77 & 0.51 \\
\hline \multirow{6}{*}{ 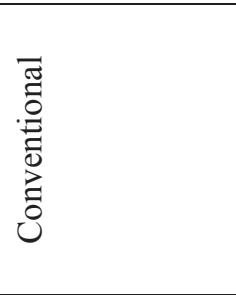 } & DSF & 2.78 & 2.36 & 2.57 \\
\hline & SOF & 2.21 & 1.73 & 1.97 \\
\hline & RSF & 1.04 & 1.39 & 1.22 \\
\hline & $\mathrm{ACF}$ & 0.70 & 1.41 & 1.06 \\
\hline & UVD & 1.18 & 1.33 & 1.26 \\
\hline & CTW & 1.18 & 2.24 & 1.71 \\
\hline \multirow{4}{*}{$\begin{array}{l}\vec{J} \\
\ddot{\Xi} \\
\tilde{O} \\
1 \\
0 \\
\simeq\end{array}$} & RO & n.a. & n.a. & n.a. \\
\hline & IEX & n.a. & n.a. & n.a. \\
\hline & $\mathrm{CC}$ & 6.06 & 11.32 & 8.69 \\
\hline & site-Remin & 7.88 & 10.25 & 9.07 \\
\hline
\end{tabular}


Multi-parametric assessment of biological stability of drinking water produced from groundwater: reverse osmosis vs. conventional treatment

\subsubsection{BGP and nutrient composition of conventionally treated drinking water and RO-treated water}

The profiling of the two treatment lines showed considerably different degrees of BGP and nutrient removal. The conventional treatment line reduced the BGP by $\sim 60 \%$ (from 1,250 \pm $100 \times 10^{3}$ in $\mathrm{AGW}$ to the range of $450 \times 10^{3}-550 \times 10^{3} \mathrm{ICC} / \mathrm{mL}$ across the different treatment steps), where the BGP of conventionally treated water (CTW) was $515 \pm 5 \times 10^{3}$ $\mathrm{ICC} / \mathrm{mL}$ (Figure 4.4A). Meanwhile, DOC decreased from $7.2 \mathrm{mg} / \mathrm{L}$ in AGW to $6.0 \mathrm{mg} / \mathrm{L}$ in CTW (Table 4.5). Notably, the humic substances, which accounted for $>70 \%$ of DOC in AGW, showed the highest removal in the conventional treatment line (from $5.2 \mathrm{mg} / \mathrm{L}$ to 4.3 $\mathrm{mg} / \mathrm{L})$.

Phosphate was also considerably reduced, mainly during DSF (>98\%, from $553 \mu \mathrm{g} / \mathrm{L} \mathrm{PO} 4-$ $\mathrm{P}$ in $\mathrm{AGW}$ to $7 \mu \mathrm{g} / \mathrm{L} \mathrm{PO}_{4}-\mathrm{P}$ in DSF), reaching down to $1 \mu \mathrm{g} / \mathrm{L} \mathrm{PO}_{4}-\mathrm{P}$ in CTW (Table 4.5). Similarly, ammonium was also reduced below $0.02 \mathrm{mg} / \mathrm{L} \mathrm{NH}_{4} \mathrm{~N}$ (limit of detection) by the conventional treatment (Table 4.5). The results showed that nitrification was the main mechanism for ammonium removal, where ammonium $\left(\mathrm{NH}_{4}{ }^{+}\right)$in $\mathrm{AGW}(2.90 \pm 0.10 \mathrm{mg} / \mathrm{L}$ $\left.\mathrm{NH}_{4}-\mathrm{N}\right)$ was completely converted into nitrate $\left(\mathrm{NO}_{3}{ }^{-}\right)$in $\mathrm{CTW}(2.77 \pm 0.40 \mathrm{mg} / \mathrm{L} \mathrm{NO}-\mathrm{N})$. Methane, which was present at 2,000-4,000 $\mu \mathrm{g}-\mathrm{CH}_{4} / \mathrm{L}$ in AGW, was reduced to $10-20 \mu \mathrm{g}$ $\mathrm{CH}_{4} / \mathrm{L}$ in CTW.

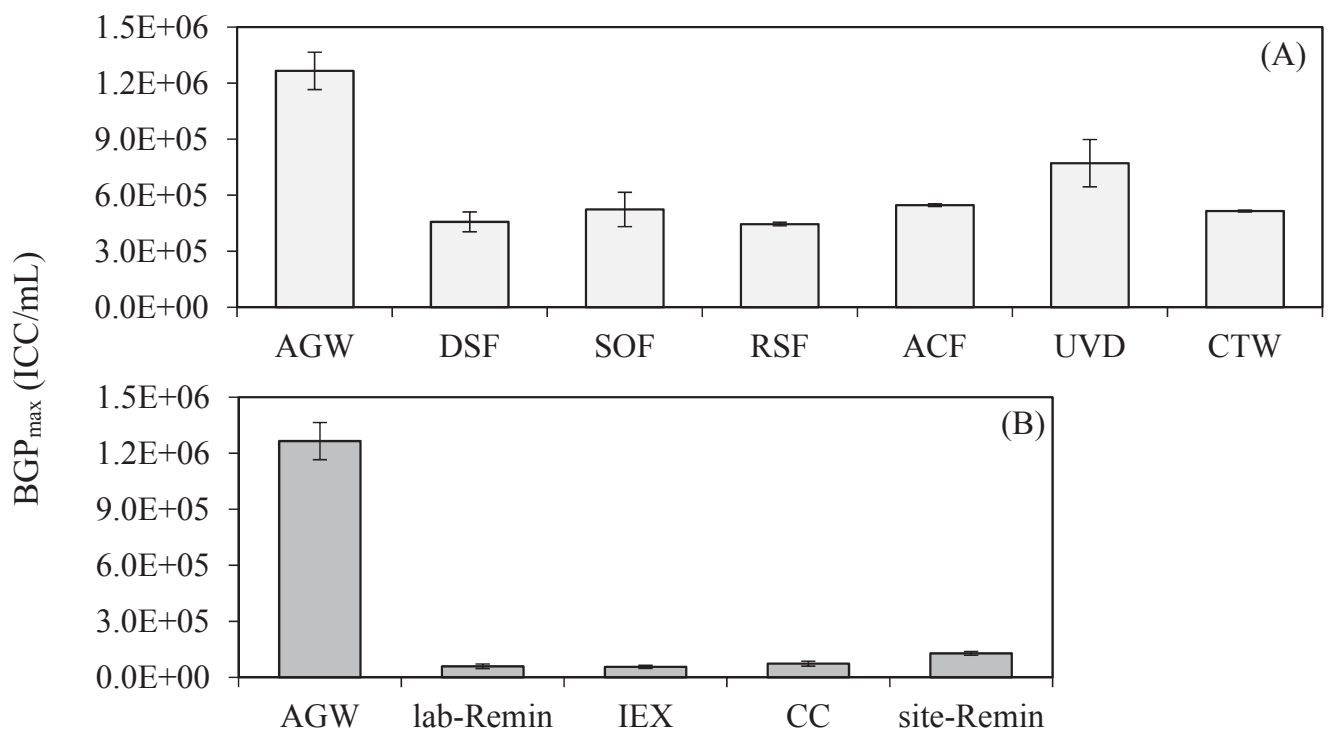

Figure 4.4. Bacterial growth potential (BGP) at each step of the conventional (A) and RObased (B) treatment lines. BGPs of RO permeate and ion exchange effluent were measured after remineralisation at the laboratory (i.e., lab-Remin and IEX respectively). Error bars represent the standard deviation of triplicate measurements. 
Multi-parametric assessment of biological stability of drinking water produced from groundwater: reverse osmosis vs. conventional treatment

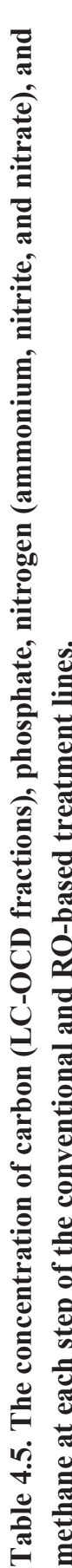

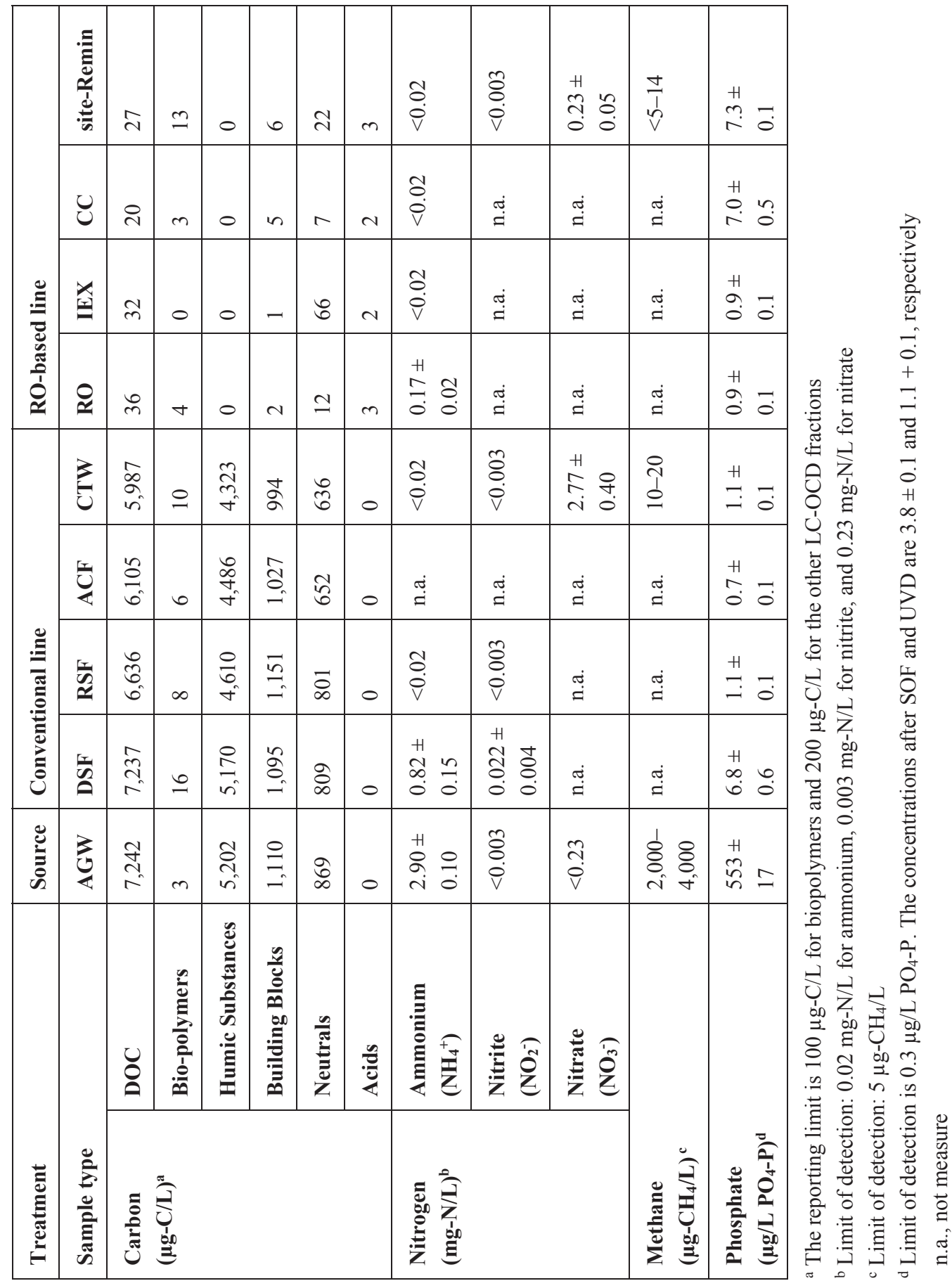


Multi-parametric assessment of biological stability of drinking water produced from groundwater: reverse osmosis vs. conventional treatment

The RO-based treatment showed a substantial BGP reduction (>96\%) from $\sim 1,250 \pm 100 \times$ $10^{3} \mathrm{ICC} / \mathrm{mL}$ in AGW to $\sim 50 \pm 12 \times 10^{3} \mathrm{ICC} / \mathrm{mL}$ in lab-Remin (i.e., RO permeate after remineralisation at the laboratory, Figure 4.4B). However, the BGP increased by $160 \%$ after remineralisation using calcite contactors $(\mathrm{CC})$ and tower aeration (site-Remin), reaching $130 \pm 10 \times 10^{3} \mathrm{ICC} / \mathrm{mL}$. The LC-OCD analysis revealed that all organic matter fractions were considerably retained by RO filtration to levels below the reporting limit (Table 4.5).

Despite the increase in BGP after post-treatment, there was no detectable increase in any DOC fraction by the LC-OCD. For phosphate, a sharp decrease from 553 to $1 \mu \mathrm{g} / \mathrm{L} \mathrm{PO}-\mathrm{P}$ was observed after RO filtration, followed by an increase across the post-treatment to $7 \mu \mathrm{g} / \mathrm{L}$ $\mathrm{PO}_{4}-\mathrm{P}$ (Table 4.5). In contrast to conventional treatment, nitrification was insignificant within the RO-based treatment line, where ammonium in AGW was mostly retained by the RO membrane $(0.17 \pm 0.02 \mathrm{mg} / \mathrm{L} \mathrm{NH} 4-\mathrm{N}$ in RO permeate), and was further removed by absorption in ion exchange resins $\left(<0.02 \mathrm{mg} / \mathrm{L} \mathrm{NH}_{4}-\mathrm{N}\right)$. This resulted in a low concentration of nitrate in RO-treated water $\left(0.23 \pm 0.05 \mathrm{mg} / \mathrm{L} \mathrm{NH}_{4}-\mathrm{N}\right)$ (Table 4.5). Methane in RO-treated water was at similar concentrations as in CTW.

The investigation of the growth-limiting nutrient (Figure 4.5) revealed that the growth in the examined water types was limited by organic carbon. For all samples, the difference between the actual BGP (i.e., without nutrient addition to the sample) and the C-limited BGP (i.e., samples spiked with all nutrients except for carbon) was insignificant $(P>0.05)$. Contrarily, the BGP of samples with limited phosphate, nitrogen, and trace elements (Fe, $\mathrm{Mn}, \mathrm{Zn}, \mathrm{Co}$, and $\mathrm{B})$ was significantly $(P<0.05)$ higher than the actual BGP of the corresponding sample. Interestingly, the P-limited BGP of site-Remin was $50 \%$ higher than that of CTW and lab-Remin.

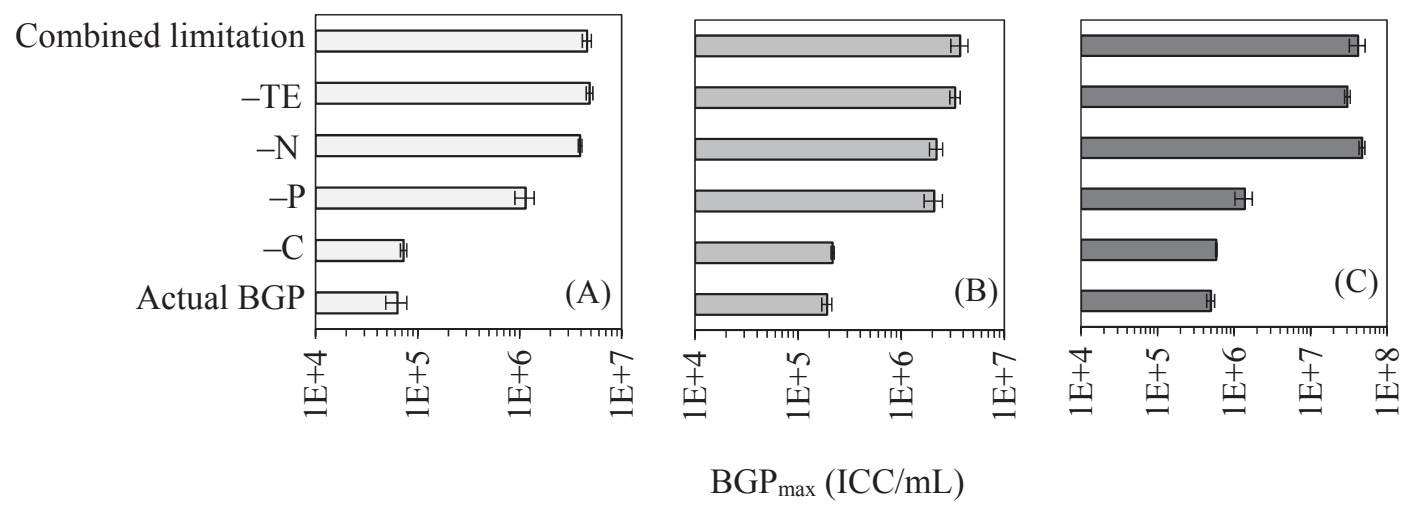

Figure 4.5. BGP of lab-Remin (the blank, A), site-Remin (B), and CTW (C) with the addition of different nutrients as given in Table 4.2 (Lower nutrient concentrations were added in the case of lab-Remin and site-Remin). Actual BGP: no nutrients added, -C: no carbon added, P: no phosphate added, -N: no nitrogen added, -TE: no trace elements added, Combined limitation: all nutrients added. Error bars represent the standard deviation of triplicate tests. 
Multi-parametric assessment of biological stability of drinking water produced from groundwater: reverse osmosis vs. conventional treatment

\subsubsection{Bacterial community}

In total, 29526 sequences were generated for 22 samples, which were assigned to 295 bacterial genera. The rarefaction curve became plateaued after 1750 and 650 sequences were retrieved for conventional and RO-based treatment lines, respectively, indicating that sufficient sample coverage was obtained (Figure 4.6). Library size per sample is given in Table 4.6, which showed that few sequences were obtained for RO-treated water due to the too low DNA content in the sample. The average sequences per sample for the entire dataset was 1400 , which was low compared with other recent studies.

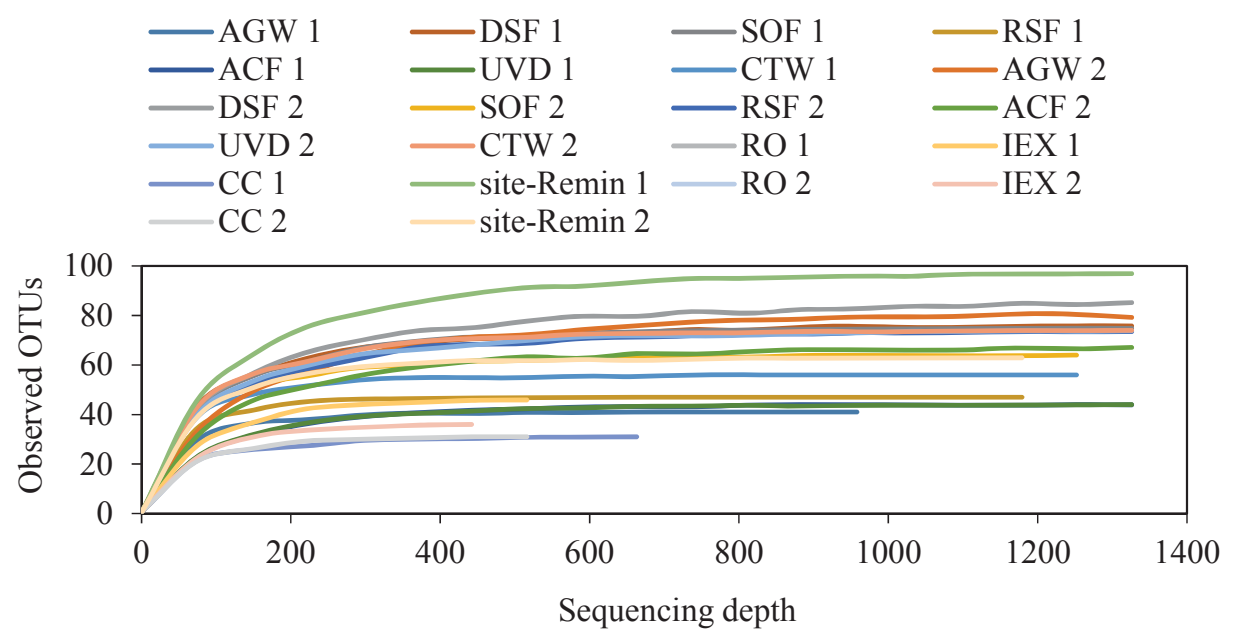

Figure 4.6. Rarefaction curve of all samples. The sequences per sample are shown in Table 4.6.

Beta diversity. The similarity in the communities obtained for the duplicate samples reflected high reproducibility and reliability (Figure 4.7, PCoA plot) of the present study. Moreover, the plot shows that the treatment shaped the composition of bacterial communities, where the observed differences between the three clusters were significant as affirmed using PERMANOVA ( $P<0.05$, Table 4.7$)$. The bacterial community of source water (AGW) were clearly distinguished from that of treated water, especially for the RObased treatment. For the conventional treatment, the bacterial communities shifted across the steps, where water after DSF, SOF, and RSF contained similar communities, but different from those detected after ACF, UVD, and CTW. For the RO-based treatment, the communities of post-treated RO permeate were closely clustered, indicating a high similarity among the samples after IEX, CC, and site-Remin. 
Multi-parametric assessment of biological stability of drinking water produced from groundwater: reverse osmosis vs. conventional treatment

Table 4.6. Sequences per sample.

\begin{tabular}{|c|c|c|}
\hline & Water sample & Library size (sequencing reads) \\
\hline \multirow{2}{*}{ 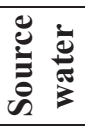 } & \multirow[t]{2}{*}{ AGW } & 2,504 \\
\hline & & 996 \\
\hline \multirow{12}{*}{ 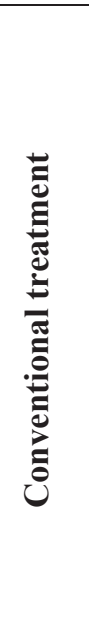 } & \multirow[t]{2}{*}{$\overline{\mathrm{DSF}}$} & 2,056 \\
\hline & & 1,532 \\
\hline & \multirow[t]{2}{*}{ SOF } & 1,303 \\
\hline & & 1,392 \\
\hline & \multirow[t]{2}{*}{ RSF } & 1,866 \\
\hline & & 1,229 \\
\hline & \multirow[t]{2}{*}{$\mathrm{ACF}$} & 2,356 \\
\hline & & 2,730 \\
\hline & \multirow[t]{2}{*}{ UVD } & 1,660 \\
\hline & & 2,014 \\
\hline & \multirow[t]{2}{*}{ CTW } & 1,513 \\
\hline & & 1,318 \\
\hline \multirow{8}{*}{ 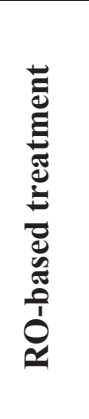 } & \multirow[t]{2}{*}{$\mathrm{RO}$} & 4 \\
\hline & & 0 \\
\hline & \multirow[t]{2}{*}{ IEX } & 548 \\
\hline & & 478 \\
\hline & \multirow[t]{2}{*}{$\mathrm{CC}$} & 711 \\
\hline & & 554 \\
\hline & \multirow[t]{2}{*}{ site-Remin } & 1,551 \\
\hline & & 1,211 \\
\hline
\end{tabular}

Alpha diversity. Looking into the dominant OTUs (genus level, relative abundance $>0.5 \%$ ) among all water samples, there were 197 OTUs assigned to 120 genera as shown in the heatmap (Figure 4.8, Table 4.8 for taxonomy information). The Venn diagrams (Figure 4.9) show that no dominant OTUs were shared between source (anaerobic) groundwater (AGW; 15 dominant OTUs) and water after any steps in the RO-based treatment line (IEX, CC, and site-Remin; 14, 10, and 33 dominant OTUs, respectively). Conversely, there were three dominant OTUs shared between AGW and CTW (23 dominant OTUs), which were assigned to the class of Deltaproteobacteria, Parcubacteria, and Omnitrophicaeota, whereas the only OTU shared between CTW and site-Remin was assigned to the family of Oligoflexaceae. 
Multi-parametric assessment of biological stability of drinking water produced from groundwater: reverse osmosis vs. conventional treatment

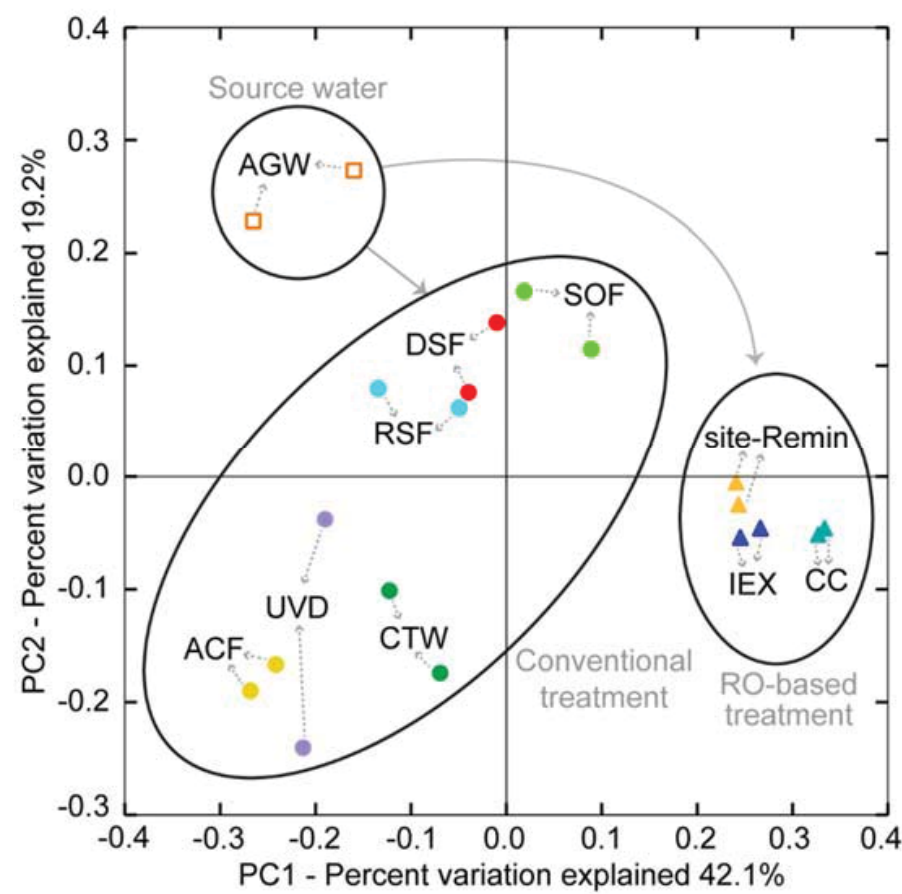

Figure 4.7. PCoA plot of weighted UniFrac distances for samples collected from source water (AGW), conventional treatment line (DSF, SOF, RSF, ACF, UVD, and CTW), and RO-based treatment line (IEX, CC, and site-Remin). DNA sequences of RO permeate were too few.

Table 4.7. PERMANOVA output showing the significance level of differences observed between bacterial communities found in samples.

\begin{tabular}{lllllll}
\hline Water type 1 & Water type 2 & Sample size & Permutations & pseudo-F & P-value & q-value \\
\hline $\begin{array}{l}\text { Conventional } \\
\text { treatment }\end{array}$ & $\begin{array}{l}\text { RO-based } \\
\text { treatment }\end{array}$ & 18 & 999 & 10.20909 & 0.001 & 0.003 \\
$\begin{array}{l}\text { Conventional } \\
\text { treatment }\end{array}$ & Source water & 14 & 999 & 3.942895 & 0.017 & 0.0255 \\
$\begin{array}{l}\text { RO-based } \\
\text { treatment }\end{array}$ & Source water & 8 & 999 & 10.57956 & 0.036 & 0.036 \\
\hline${ }^{*}$ Difference is significant if $P$-value is $<0.05$ & & & &
\end{tabular}

${ }^{*}$ Difference is significant if $P$-value is $<0.05$ 
Multi-parametric assessment of biological stability of drinking water produced from groundwater: reverse osmosis vs. conventional treatment

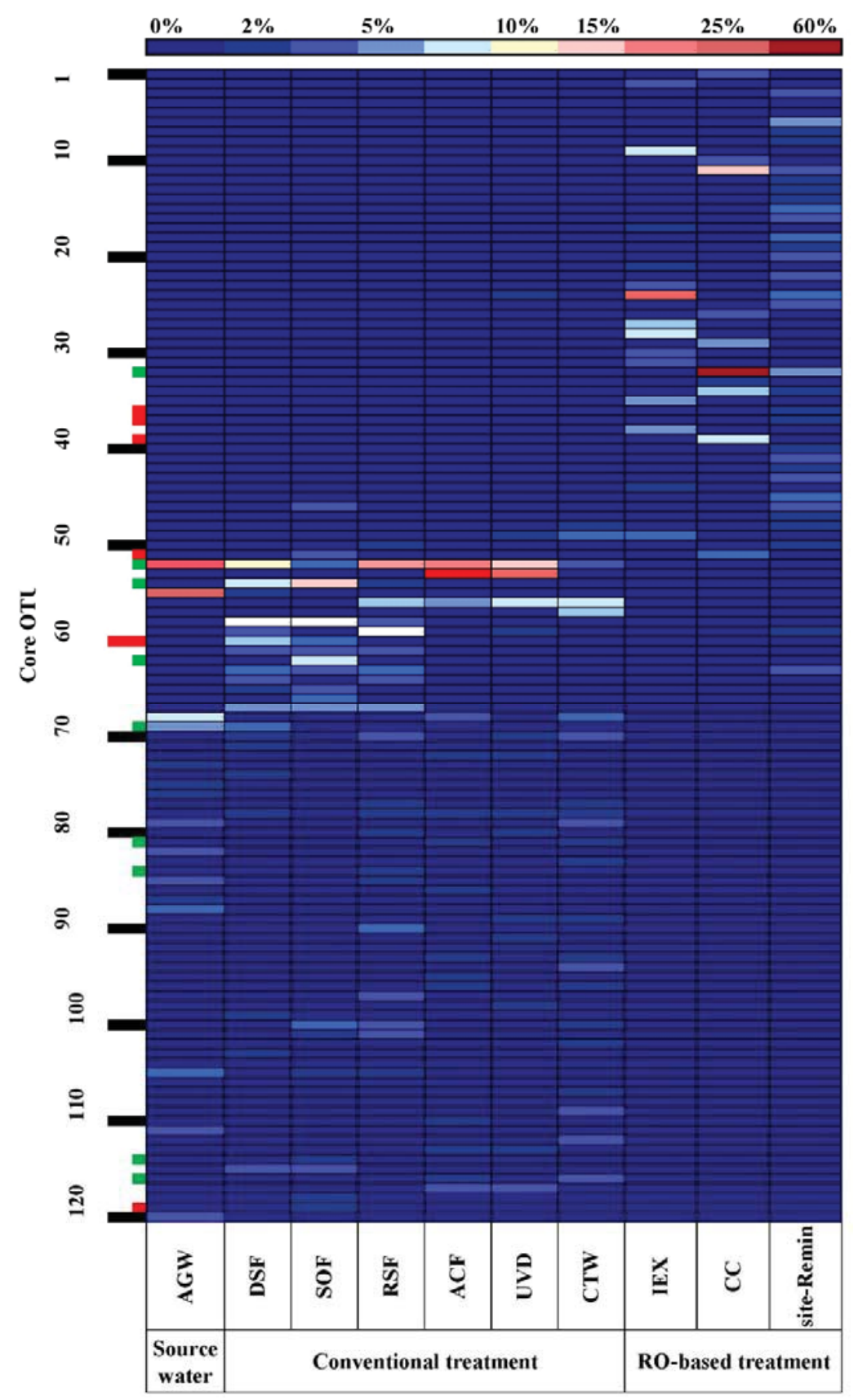

Figure 4.8. Heatmap showing the dominant OTUs (genus level) and their relative abundance (average of duplicate) in water samples. DNA sequences of RO permeate were too few. The full taxonomy information of the dominant OTUs is given in Table 4.8. Black marks on the $y$ axis represent the OTU number given, red marks represent methanotrophs, and green marks represent nitrifiers. 
Multi-parametric assessment of biological stability of drinking water produced from groundwater: reverse osmosis vs. conventional treatment

Table 4.8. The full taxonomy information of the dominant OTUs in water samples (genus level, relative abundance of $>0.5 \%$ ).

\begin{tabular}{|c|c|c|c|c|c|}
\hline \multirow[t]{2}{*}{ ID } & \multicolumn{5}{|c|}{ Taxonomy } \\
\hline & Phylum & Class & Order & Family & Genus \\
\hline 1 & Acidobacteria & Holophagae & Holophagales & Holophagaceae & Geothrix \\
\hline 2 & Bacteroidetes & Bacteroidia & Chitinophagales & Chitinophagaceae & Heliimonas \\
\hline 3 & Bacteroidetes & Bacteroidia & Sphingobacteriales & $\begin{array}{l}\text { NS11-12 marine } \\
\text { group }\end{array}$ & uncultured bacterium \\
\hline 4 & Bacteroidetes & Bacteroidia & Sphingobacteriales & env.OPS 17 & metagenome \\
\hline 5 & Bacteroidetes & Bacteroidia & Sphingobacteriales & env.OPS 17 & $\begin{array}{l}\text { uncultured } \\
\text { Bacteroidetes bacterium }\end{array}$ \\
\hline 6 & Bacteroidetes & Ignavibacteria & OPB56 & & \\
\hline 7 & Chlamydiae & Chlamydiae & Chlamydiales & Simkaniaceae & uncultured \\
\hline 8 & Chlamydiae & Chlamydiae & Chlamydiales & Simkaniaceae & \\
\hline 9 & Cyanobacteria & Melainabacteria & Obscuribacterales & $\begin{array}{l}\text { uncultured } \\
\text { cyanobacterium }\end{array}$ & $\begin{array}{l}\text { uncultured } \\
\text { cyanobacterium }\end{array}$ \\
\hline 10 & Elusimicrobia & Elusimicrobia & Lineage IV & $\begin{array}{l}\text { Elusimicrobia } \\
\text { bacterium } \\
\text { RIFCSPHIGHO2_02 } \\
\text { FULL_61_10 }\end{array}$ & \\
\hline 11 & Epsilonbacteraeota & Campylobacteria & Campylobacterales & Thiovulaceae & Sulfuricurvum \\
\hline 12 & Patescibacteria & Gracilibacteria & JGI 0000069-P22 & & \\
\hline 13 & Patescibacteria & Gracilibacteria & & & \\
\hline 14 & Patescibacteria & Microgenomatia & $\begin{array}{l}\text { Candidatus } \\
\text { Collierbacteria }\end{array}$ & uncultured bacterium & uncultured bacterium \\
\hline 15 & Planctomycetes & Planctomycetacia & Pirellulales & Pirellulaceae & uncultured \\
\hline 16 & Planctomycetes & vadinHA49 & $\begin{array}{l}\text { uncultured soil } \\
\text { bacterium }\end{array}$ & $\begin{array}{l}\text { uncultured soil } \\
\text { bacterium }\end{array}$ & $\begin{array}{l}\text { uncultured soil } \\
\text { bacterium }\end{array}$ \\
\hline 17 & Proteobacteria & Alphaproteobacteria & Caulobacterales & Caulobacteraceae & Caulobacter \\
\hline 18 & Proteobacteria & Alphaproteobacteria & Caulobacterales & Hyphomonadaceae & SWB02 \\
\hline 19 & Proteobacteria & Alphaproteobacteria & Dongiales & Dongiaceae & Dongia \\
\hline 20 & Proteobacteria & Alphaproteobacteria & Reyranellales & Reyranellaceae & Reyranella \\
\hline 21 & Proteobacteria & Alphaproteobacteria & Rhizobiales & Rhizobiaceae & Mesorhizobium \\
\hline 22 & Proteobacteria & Alphaproteobacteria & Rhizobiales & $\begin{array}{l}\text { Rhizobiales Incertae } \\
\text { Sedis }\end{array}$ & uncultured \\
\hline 23 & Proteobacteria & Alphaproteobacteria & Sphingomonadales & Sphingomonadaceae & Novosphingobium \\
\hline 24 & Proteobacteria & Alphaproteobacteria & Sphingomonadales & Sphingomonadaceae & Sphingomonas \\
\hline 25 & Proteobacteria & Deltaproteobacteria & Bdellovibrionales & Bdellovibrionaceae & Bdellovibrio \\
\hline 26 & Proteobacteria & Deltaproteobacteria & Desulfuromonadales & Geobacteraceae & Geobacter \\
\hline 27 & Proteobacteria & Gammaproteobacteria & Betaproteobacteriales & Burkholderiaceae & Aquabacterium \\
\hline 28 & Proteobacteria & Gammaproteobacteria & Betaproteobacteriales & Burkholderiaceae & $\begin{array}{l}\text { Burkholderia- } \\
\text { Caballeronia- } \\
\text { Paraburkholderia }\end{array}$ \\
\hline 29 & Proteobacteria & Gammaproteobacteria & Betaproteobacteriales & Burkholderiaceae & Leptothrix \\
\hline 30 & Proteobacteria & Gammaproteobacteria & Betaproteobacteriales & Burkholderiaceae & $\begin{array}{l}\text { [Polyangium] } \\
\text { brachysporum group }\end{array}$ \\
\hline 31 & Proteobacteria & Gammaproteobacteria & Betaproteobacteriales & Chitinibacteraceae & Formivibrio \\
\hline 32 & Proteobacteria & Gammaproteobacteria & Betaproteobacteriales & Nitrosomonadaceae & GOUTA6 \\
\hline 3 & Proteobacteria & Gammaproteobacteria & Betaproteobacteriales & Rhodocyclaceae & Propionivibrio \\
\hline 34 & Proteobacteria & Gammaproteobacteria & Betaproteobacteriales & Sulfuricellaceae & Ferritrophicum \\
\hline 35 & Proteobacteria & Gammaproteobacteria & Betaproteobacteriales & Sulfuricellaceae & Sulfuricella \\
\hline
\end{tabular}


Multi-parametric assessment of biological stability of drinking water produced from groundwater: reverse osmosis vs. conventional treatment

\begin{tabular}{|c|c|c|c|c|c|}
\hline \multirow[t]{2}{*}{ ID } & \multicolumn{5}{|c|}{ Taxonomy } \\
\hline & Phylum & Class & Order & Family & Genus \\
\hline 36 & Proteobacteria & Gammaproteobacteria & Methylococcales & Methylomonaceae & Methylovulum \\
\hline 37 & Proteobacteria & Gammaproteobacteria & Methylococcales & Methylomonaceae & uncultured \\
\hline 38 & Proteobacteria & Gammaproteobacteria & $\begin{array}{l}\text { Gammaproteobacteria } \\
\text { Incertae Sedis }\end{array}$ & Unknown Family & Acidibacter \\
\hline 39 & Proteobacteria & Gammaproteobacteria & Methylococcales & Methylomonaceae & Methylobacter \\
\hline 40 & Proteobacteria & Gammaproteobacteria & Xanthomonadales & Rhodanobacteraceae & Tahibacter \\
\hline 41 & Proteobacteria & Gammaproteobacteria & & & \\
\hline 42 & Verrucomicrobia & Verrucomicrobiae & Chthoniobacterales & Terrimicrobiaceae & Terrimicrobium \\
\hline 43 & Verrucomicrobia & Verrucomicrobiae & Verrucomicrobiales & Verrucomicrobiaceae & uncultured \\
\hline 44 & Proteobacteria & Gammaproteobacteria & Salinisphaerales & Solimonadaceae & Nevskia \\
\hline 45 & Bacteroidetes & Bacteroidia & Sphingobacteriales & KD3-93 & $\begin{array}{l}\text { uncultured } \\
\text { Bacteroidetes bacterium }\end{array}$ \\
\hline 46 & Bacteroidetes & Bacteroidia & Cytophagales & Microscillaceae & uncultured \\
\hline 47 & Planctomycetes & BD7-11 & $\begin{array}{l}\text { uncultured bacterium } \\
\text { PHOS-HE93 }\end{array}$ & $\begin{array}{l}\text { uncultured bacterium } \\
\text { PHOS-HE93 }\end{array}$ & $\begin{array}{l}\text { uncultured bacterium } \\
\text { PHOS-HE93 }\end{array}$ \\
\hline 48 & Proteobacteria & Deltaproteobacteria & Oligoflexales & Oligoflexaceae & uncultured \\
\hline 49 & Proteobacteria & Gammaproteobacteria & Betaproteobacteriales & Burkholderiaceae & Curvibacter \\
\hline 50 & Proteobacteria & Gammaproteobacteria & Diplorickettsiales & Diplorickettsiaceae & uncultured \\
\hline 51 & Proteobacteria & Gammaproteobacteria & Methylococcales & Methylomonaceae & Crenothrix \\
\hline 52 & Omnitrophicaeota & uncultured bacterium & uncultured bacterium & uncultured bacterium & uncultured bacterium \\
\hline 53 & Patescibacteria & ABY1 & $\begin{array}{l}\text { Candidatus } \\
\text { Uhrbacteria }\end{array}$ & $\begin{array}{l}\text { Candidatus } \\
\text { Uhrbacteria bacterium } \\
\text { RIFOXYC12_FULL_ } \\
57 \text { 11 }\end{array}$ & \\
\hline 54 & Nitrospirae & Nitrospira & Nitrospirales & Nitrospiraceae & Nitrospira \\
\hline 55 & Nitrospirae & Thermodesulfovibrionia & uncultured & $\begin{array}{l}\text { uncultured } \\
\text { Thermodesulfovibrio } \\
\text { spp. }\end{array}$ & $\begin{array}{l}\text { uncultured } \\
\text { Thermodesulfovibrio } \\
\text { spp. }\end{array}$ \\
\hline 56 & Patescibacteria & Parcubacteria & $\begin{array}{l}\text { Candidatus } \\
\text { Kaiserbacteria }\end{array}$ & $\begin{array}{l}\text { Parcubacteria } \\
\text { bacterium OLB19 }\end{array}$ & $\begin{array}{l}\text { Parcubacteria bacterium } \\
\text { OLB19 }\end{array}$ \\
\hline 57 & Patescibacteria & Parcubacteria & $\begin{array}{l}\text { Candidatus } \\
\text { Kaiserbacteria }\end{array}$ & & \\
\hline 58 & Proteobacteria & Gammaproteobacteria & Betaproteobacteriales & Gallionellaceae & Gallionella \\
\hline 59 & Proteobacteria & Alphaproteobacteria & Rickettsiales & SM2D12 & metagenome \\
\hline 60 & Proteobacteria & Gammaproteobacteria & Methylococcales & Methylomonaceae & \\
\hline 61 & Proteobacteria & Deltaproteobacteria & Bdellovibrionales & Bacteriovoracaceae & Bacteriovorax \\
\hline 62 & Proteobacteria & Gammaproteobacteria & Betaproteobacteriales & Nitrosomonadaceae & Nitrosomonas \\
\hline 63 & Proteobacteria & Alphaproteobacteria & Micavibrionales & Micavibrionaceae & uncultured \\
\hline 64 & Proteobacteria & Alphaproteobacteria & Micavibrionales & uncultured & \\
\hline 65 & Proteobacteria & Alphaproteobacteria & Micavibrionales & uncultured & $\begin{array}{l}\text { Alphaproteobacteria } \\
\text { bacterium } \\
\text { CG1_02_46_17 }\end{array}$ \\
\hline 66 & Proteobacteria & Alphaproteobacteria & Micavibrionales & uncultured & metagenome \\
\hline 67 & Bacteroidetes & Bacteroidia & Flavobacteriales & Crocinitomicaceae & uncultured \\
\hline 68 & Proteobacteria & Deltaproteobacteria & Sva0485 & & \\
\hline 69 & Nitrospirae & Thermodesulfovibrionia & uncultured & $\begin{array}{l}\text { uncultured Nitrospirae } \\
\text { bacterium }\end{array}$ & $\begin{array}{l}\text { uncultured Nitrospirae } \\
\text { bacterium }\end{array}$ \\
\hline
\end{tabular}


Multi-parametric assessment of biological stability of drinking water produced from groundwater: reverse osmosis vs. conventional treatment

\begin{tabular}{|c|c|c|c|c|c|}
\hline \multirow[t]{2}{*}{ ID } & \multicolumn{5}{|c|}{ Taxonomy } \\
\hline & Phylum & Class & Order & Family & Genus \\
\hline 70 & Patescibacteria & Parcubacteria & $\begin{array}{l}\text { Candidatus } \\
\text { Lloydbacteria }\end{array}$ & $\begin{array}{l}\text { Candidatus } \\
\text { Lloydbacteria } \\
\text { bacterium } \\
\text { RIFOXYC12_FULL_ } \\
46 \_25\end{array}$ & \\
\hline 71 & Patescibacteria & Parcubacteria & $\begin{array}{l}\text { Candidatus } \\
\text { Moranbacteria }\end{array}$ & uncultured bacterium & uncultured bacterium \\
\hline 72 & Patescibacteria & Parcubacteria & $\begin{array}{l}\text { Candidatus } \\
\text { Nomurabacteria }\end{array}$ & uncultured bacterium & uncultured bacterium \\
\hline 73 & Patescibacteria & Parcubacteria & $\begin{array}{l}\text { Candidatus } \\
\text { Portnoybacteria }\end{array}$ & & \\
\hline 74 & Patescibacteria & Parcubacteria & $\begin{array}{l}\text { Candidatus } \\
\text { Zambryskibacteria }\end{array}$ & $\begin{array}{l}\text { Parcubacteria group } \\
\text { bacterium } \\
\text { GW2011_GWA2_40 } \\
\text { _14 }\end{array}$ & \\
\hline 75 & Patescibacteria & Parcubacteria & UBA9983 & uncultured bacterium & uncultured bacterium \\
\hline 76 & Patescibacteria & Parcubacteria & $\begin{array}{l}\text { uncultured } \\
\text { Parcubacteria group } \\
\text { bacterium }\end{array}$ & $\begin{array}{l}\text { uncultured } \\
\text { Parcubacteria group } \\
\text { bacterium }\end{array}$ & $\begin{array}{l}\text { uncultured } \\
\text { Parcubacteria group } \\
\text { bacterium }\end{array}$ \\
\hline 77 & Patescibacteria & Parcubacteria & uncultured bacterium & uncultured bacterium & uncultured bacterium \\
\hline 78 & Patescibacteria & Parcubacteria & $\begin{array}{l}\text { uncultured soil } \\
\text { bacterium }\end{array}$ & $\begin{array}{l}\text { uncultured soil } \\
\text { bacterium }\end{array}$ & $\begin{array}{l}\text { uncultured soil } \\
\text { bacterium }\end{array}$ \\
\hline 79 & Patescibacteria & Parcubacteria & & & \\
\hline 80 & Patescibacteria & WWE3 & uncultured bacterium & uncultured bacterium & uncultured bacterium \\
\hline 81 & Omnitrophicaeota & Omnitrophica WOR-2 & $\begin{array}{l}\text { bacterium } \\
\text { RIFCSPLOWO2_12_ } \\
\text { FULL_51_24 }\end{array}$ & & \\
\hline 82 & Omnitrophicaeota & $\begin{array}{l}\text { uncultured Omnitrophica } \\
\text { bacterium }\end{array}$ & $\begin{array}{l}\text { uncultured } \\
\text { Omnitrophica } \\
\text { bacterium }\end{array}$ & $\begin{array}{l}\text { uncultured } \\
\text { Omnitrophica } \\
\text { bacterium }\end{array}$ & $\begin{array}{l}\text { uncultured } \\
\text { Omnitrophica bacterium }\end{array}$ \\
\hline 83 & Omnitrophicaeota & $\begin{array}{l}\text { uncultured beta } \\
\text { proteobacterium }\end{array}$ & $\begin{array}{l}\text { uncultured beta } \\
\text { proteobacterium }\end{array}$ & $\begin{array}{l}\text { uncultured beta } \\
\text { proteobacterium }\end{array}$ & $\begin{array}{l}\text { uncultured beta } \\
\text { proteobacterium }\end{array}$ \\
\hline 84 & Omnitrophicaeota & & & & \\
\hline 85 & Patescibacteria & ABY1 & $\begin{array}{l}\text { Candidatus } \\
\text { Falkowbacteria }\end{array}$ & uncultured bacterium & uncultured bacterium \\
\hline 86 & Patescibacteria & ABY1 & $\begin{array}{l}\text { Candidatus } \\
\text { Falkowbacteria }\end{array}$ & & \\
\hline 87 & Patescibacteria & ABY1 & $\begin{array}{l}\text { Candidatus } \\
\text { Kerfeldbacteria }\end{array}$ & $\begin{array}{l}\text { Candidatus } \\
\text { Falkowbacteria } \\
\text { bacterium RBG13 } 39 \\
14\end{array}$ & \\
\hline 88 & Patescibacteria & ABY1 & $\begin{array}{l}\text { Candidatus } \\
\text { Kerfeldbacteria }\end{array}$ & uncultured bacterium & uncultured bacterium \\
\hline 89 & Patescibacteria & ABY1 & $\begin{array}{l}\text { Candidatus } \\
\text { Magasanikbacteria }\end{array}$ & uncultured bacterium & uncultured bacterium \\
\hline 90 & Patescibacteria & ABY1 & $\begin{array}{l}\text { Candidatus } \\
\text { Uhrbacteria }\end{array}$ & & \\
\hline 91 & Patescibacteria & Gracilibacteria & $\begin{array}{l}\text { Candidatus } \\
\text { Peregrinibacteria }\end{array}$ & uncultured bacterium & uncultured bacterium \\
\hline
\end{tabular}


Multi-parametric assessment of biological stability of drinking water produced from groundwater: reverse osmosis vs. conventional treatment

\begin{tabular}{|c|c|c|c|c|c|}
\hline \multirow[t]{2}{*}{ ID } & \multicolumn{5}{|c|}{ Taxonomy } \\
\hline & Phylum & Phylum & Phylum & Phylum & Phylum \\
\hline 92 & Patescibacteria & Gracilibacteria & $\begin{array}{l}\text { Candidatus } \\
\text { Peribacteria }\end{array}$ & $\begin{array}{l}\text { uncultured bacterium } \\
\text { GKS2-30 }\end{array}$ & $\begin{array}{l}\text { uncultured bacterium } \\
\text { GKS2-30 }\end{array}$ \\
\hline 93 & Patescibacteria & Gracilibacteria & $\begin{array}{l}\text { Candidatus } \\
\text { Peribacteria }\end{array}$ & & \\
\hline 94 & Patescibacteria & Parcubacteria & $\begin{array}{l}\text { Candidatus } \\
\text { Kaiserbacteria }\end{array}$ & uncultured bacterium & uncultured bacterium \\
\hline 95 & Patescibacteria & Parcubacteria & $\begin{array}{l}\text { Candidatus } \\
\text { Kaiserbacteria }\end{array}$ & $\begin{array}{l}\text { uncultured soil } \\
\text { bacterium }\end{array}$ & $\begin{array}{l}\text { uncultured soil } \\
\text { bacterium }\end{array}$ \\
\hline 96 & Patescibacteria & Parcubacteria & $\begin{array}{l}\text { Candidatus } \\
\text { Adlerbacteria }\end{array}$ & uncultured bacterium & uncultured bacterium \\
\hline 97 & Proteobacteria & Deltaproteobacteria & Syntrophobacterales & Syntrophaceae & uncultured \\
\hline 98 & Proteobacteria & Gammaproteobacteria & Beggiatoales & Beggiatoaceae & uncultured \\
\hline 99 & Proteobacteria & Gammaproteobacteria & Salinisphaerales & Solimonadaceae & Solimonas \\
\hline 100 & Proteobacteria & Gammaproteobacteria & Salinisphaerales & Solimonadaceae & uncultured \\
\hline 101 & Acidobacteria & Subgroup 6 & & & \\
\hline 102 & Actinobacteria & Actinobacteria & Propionibacteriales & Nocardioidaceae & Nocardioides \\
\hline 103 & Bacteroidetes & Bacteroidia & Sphingobacteriales & KD3-93 & \\
\hline 104 & Cyanobacteria & Melainabacteria & Vampirovibrionales & uncultured bacterium & uncultured bacterium \\
\hline 105 & Firmicutes & & & & \\
\hline 106 & Proteobacteria & Alphaproteobacteria & Rhodospirillales & uncultured & $\begin{array}{l}\text { uncultured soil } \\
\text { bacterium }\end{array}$ \\
\hline 107 & Proteobacteria & Alphaproteobacteria & Rickettsiales & $\mathrm{AB} 1$ & uncultured bacterium \\
\hline 108 & Proteobacteria & Alphaproteobacteria & Rickettsiales & Mitochondria & metagenome \\
\hline 109 & Proteobacteria & Alphaproteobacteria & Rickettsiales & SM2D12 & uncultured bacterium \\
\hline 110 & Proteobacteria & Alphaproteobacteria & uncultured & uncultured bacterium & uncultured bacterium \\
\hline 111 & Proteobacteria & Deltaproteobacteria & Desulfobacterales & Desulfobulbaceae & uncultured \\
\hline 112 & Proteobacteria & Deltaproteobacteria & Oligoflexales & 0319-6G20 & \\
\hline 113 & Proteobacteria & Gammaproteobacteria & Betaproteobacteriales & Burkholderiaceae & Polaromonas \\
\hline 114 & Proteobacteria & Gammaproteobacteria & Betaproteobacteriales & Gallionellaceae & Candidatus Nitrotoga \\
\hline 115 & Proteobacteria & Gammaproteobacteria & Betaproteobacteriales & Gallionellaceae & Sideroxydans \\
\hline 116 & Proteobacteria & Gammaproteobacteria & Betaproteobacteriales & Nitrosomonadaceae & MND1 \\
\hline 117 & Proteobacteria & Gammaproteobacteria & Betaproteobacteriales & TRA3-20 & \\
\hline 118 & Proteobacteria & Gammaproteobacteria & $\begin{array}{l}\text { Gammaproteobacteria } \\
\text { Incertae Sedis }\end{array}$ & Unknown Family & Candidatus Berkiella \\
\hline 119 & Proteobacteria & Gammaproteobacteria & Methylococcales & Methylomonaceae & Methyloglobulus \\
\hline 120 & Synergistetes & Synergistia & Synergistales & Synergistaceae & JGI-0000079-D21 \\
\hline
\end{tabular}


Multi-parametric assessment of biological stability of drinking water produced from groundwater: reverse osmosis vs. conventional treatment

(A)

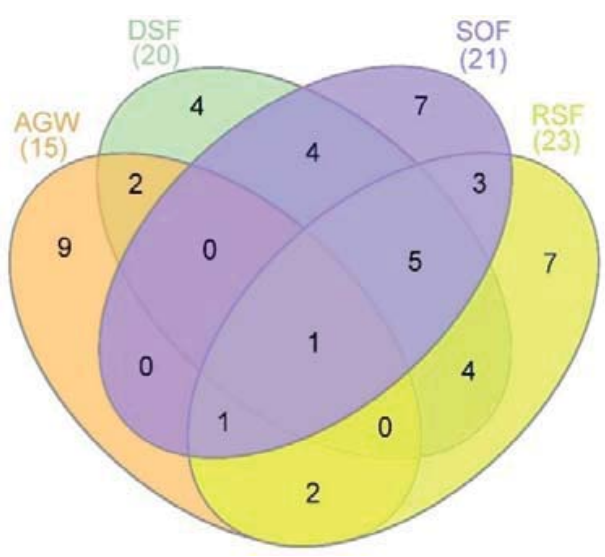

(C)

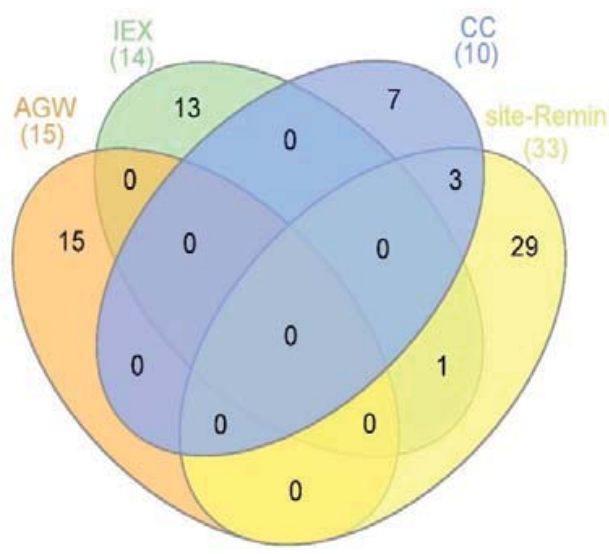

(B)

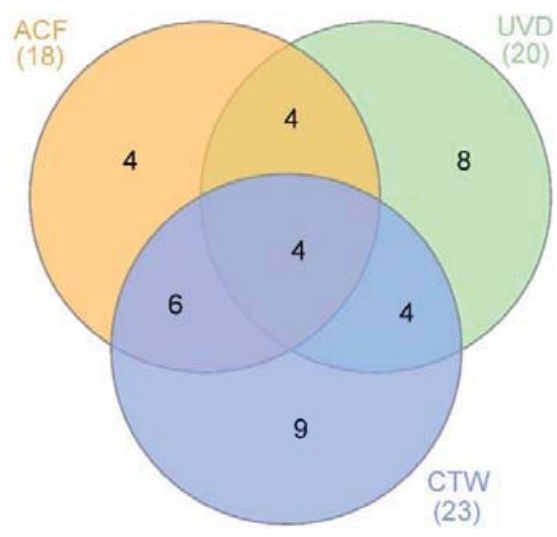

(D)

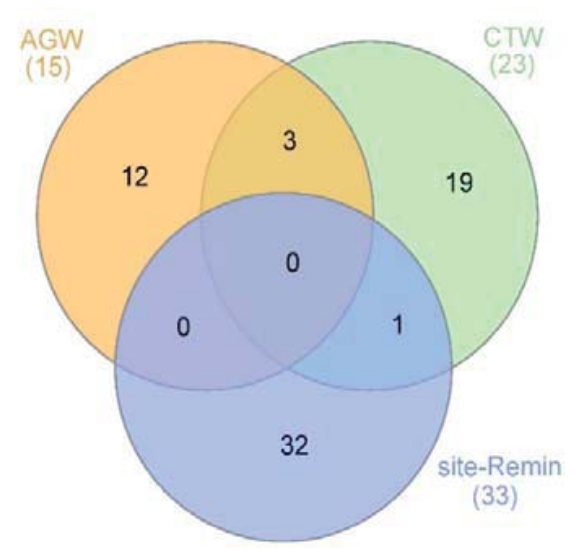

Figure 4.9. Venn diagrams showing the dominant OTUs shared between water samples after each step in conventional treatment line ( $\mathrm{A}$ and $\mathrm{B})$, RO-based treatment line $(\mathrm{C})$, and between source water (AGW) and finished water of both treatment lines (D).

Community composition. The column plots at phylum, class, and order levels are presented in Figure 4.10. At phylum level, Proteobacteria was significantly present in all samples irrespective of the treatment, where the relative abundance ranged from $10 \%$ in source water (AGW) to $20-50 \%$ after conventional treatment and $55-80 \%$ in water after RO-based treatment. Patescibacteria was more abundant in conventionally treated water $(20-60 \%)$ than RO-treated water $(<5 \%)$. Omnitrophicaeota and Nitrospirae were dominant in source water only ( $\mathrm{AGW}, \sim 30 \%$ ), where their relative abundance decreased to $1-19 \%$ after conventional treatment, and below $0.5 \%$ after RO-based treatment. 
Multi-parametric assessment of biological stability of drinking water produced from groundwater: reverse osmosis vs. conventional treatment
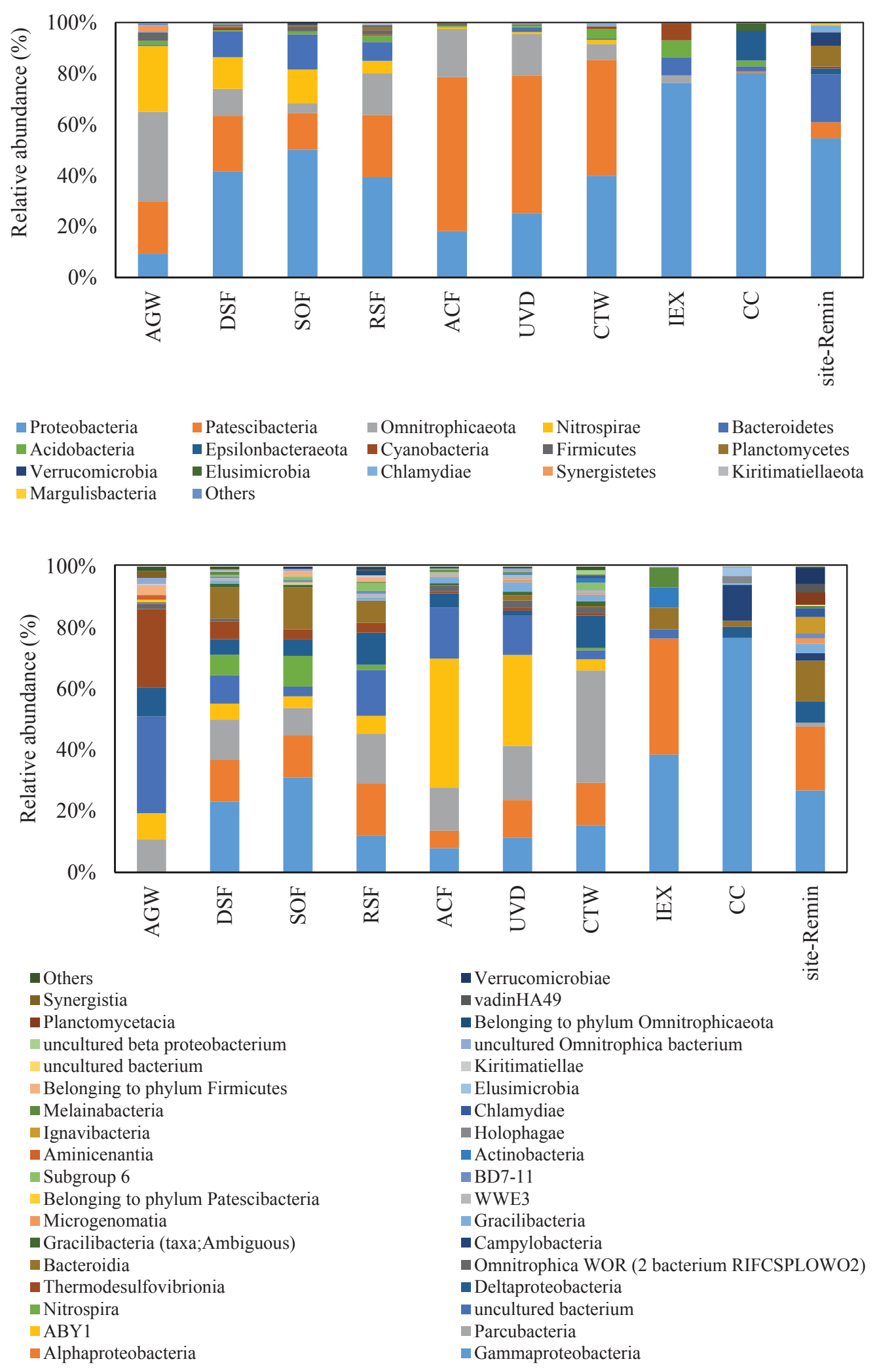
Multi-parametric assessment of biological stability of drinking water produced from groundwater: reverse osmosis vs. conventional treatment
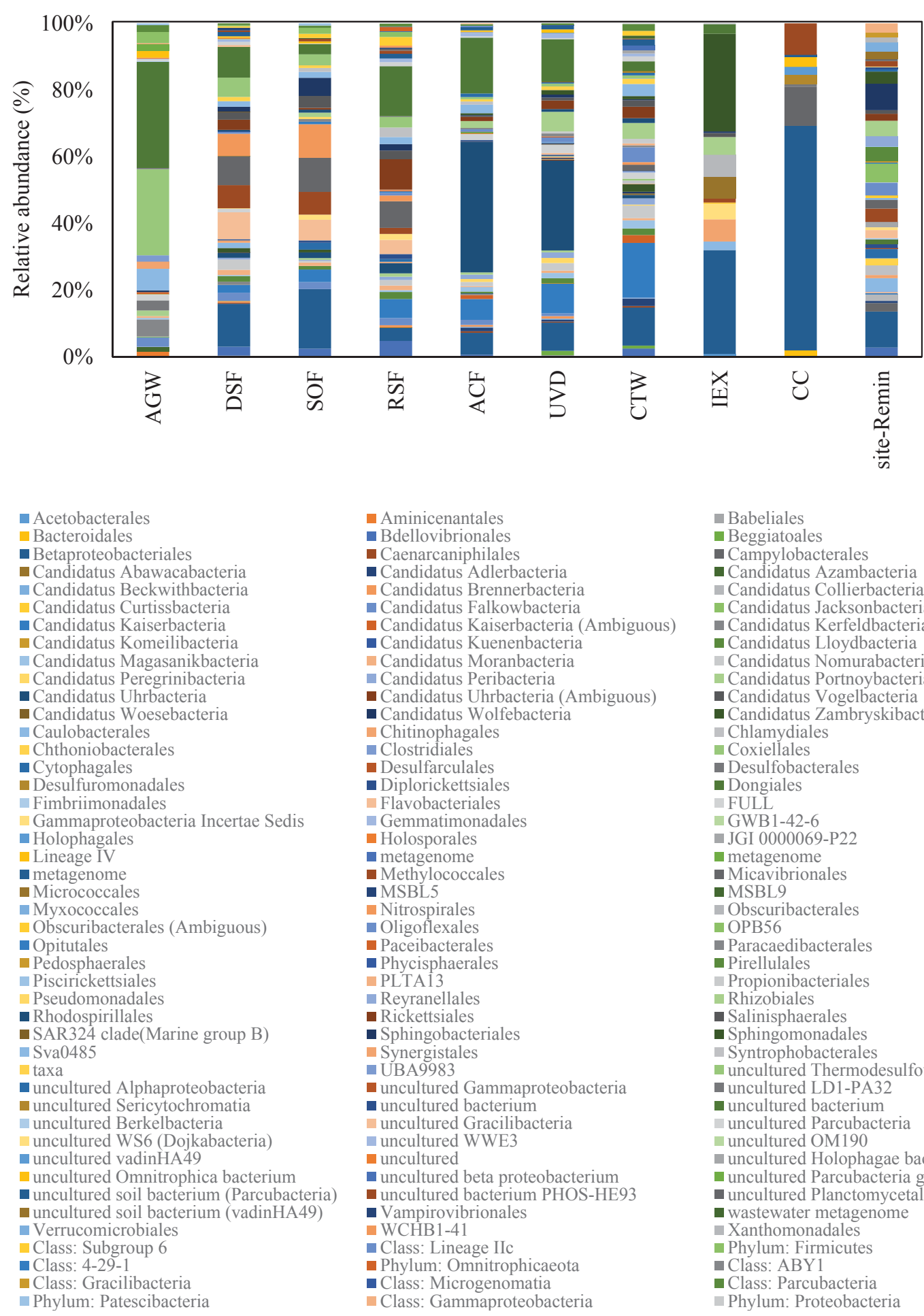

Aminicenantales

- Bdellovibrionales

- Caenarcaniphilales

- Candidatus Adlerbacteri

- Candidatus Brennerbacteria

- Candidatus Falkowbacteria

- Candidatus Kaiserbacteria (Ambiguous)

- Candidatus Kuenenbacteria

- Candidatus Moranbacteria

- Candidatus Peribacteria

- Candidatus Uhrbacteria (Ambiguous)

- Candidatus Wolfebacteria

- Chitinophagales

- Clostridiales

- Desulfarculales

- Diplorickettsiales

- Flavobacteriales

Gemmatimonadales

- Holosporales

- metagenome

- Methylococcales

- MSBL5

- Nitrospirales

- Oligoflexales

- Paceibacterales

- Phycisphaerales

- PLTA13

- Reyranellales

- Rickettsiales

- Sphingobacteriales

- Synergistales

- UBA9983

- uncultured Gammaproteobacteria

- uncultured bacterium

- uncultured Gracilibacteria

- uncultured WWE3

- uncultured

- uncultured beta proteobacterium

uncultured bacterium PHOS-HE93

- Vampirovibrionales

- WCHB1-41

- Class: Lineage IIc

Phylum: Omnitrophicaeota

- Class: Microgenomatia

Class: Gammaproteobacteria

\author{
Babeliales \\ Beggiatoales \\ - Campylobacterales \\ - Candidatus Azambacteria \\ - Candidatus Collierbacteria \\ - Candidatus Jacksonbacteria \\ - Candidatus Kerfeldbacteria \\ - Candidatus Lloydbacteria \\ - Candidatus Nomurabacteria \\ - Candidatus Portnoybacteria \\ - Candidatus Vogelbacteria \\ - Candidatus Zambryskibacteria \\ Chlamydiales \\ Coxiellales \\ Desulfobacterales \\ Dongiales \\ FULL \\ GWB1-42-6 \\ JGI 0000069-P22 \\ metagenome \\ - Micavibrionales \\ - MSBL9 \\ Obscuribacterales \\ - OPB56 \\ Paracaedibacterales \\ - Pirellulales \\ Propionibacteriales \\ Rhizobiales \\ - Salinisphaerales \\ - Sphingomonadales \\ Syntrophobacterales \\ - uncultured Thermodesulfovibrionia \\ nuncultured LD1-PA32 \\ - uncultured bacterium \\ uncultured Parcubacteria \\ - uncultured OM190 \\ - uncultured Holophagae bacterium \\ n uncultured Parcubacteria group bacterium \\ - uncultured Planctomycetales bacterium \\ wastewater metagenome \\ Xanthomonadales \\ - Phylum: Firmicutes \\ Class: ABY1 \\ - Class: Parcubacteria \\ Phylum: Proteobacteria
}

Figure 4.10. Bacterial community composition at phylum level (top), class level (middle), and order level (bottom). Relative abundances were calculated based on the average of duplicate measurements for each sample. 
Multi-parametric assessment of biological stability of drinking water produced from groundwater: reverse osmosis vs. conventional treatment

At genus level, OTUs belonging to families characterised as methanotrophs (methaneoxidising bacteria) were detected in both treatment lines after steps where oxygen was introduced (Figure 4.8): 4 OTUs for conventional treatment exclusively after DSF and SOF, 4 OTUs for RO-based treatment exclusively after CC and site-Remin, among which 1 OTU was shared by all (Table 4.9). Interestingly, all 8 OTUs were assigned to type I methanotrophs that belong to Methylomonaceae, including Methylovulum spp. (1\%), Methylobacter spp. (6\%), Methyloglobulus spp. (2\%), Crenothrix spp. (2-3\%), and other uncultured genera $(2-5 \%)$. OTUs belonging to the families which characterised as nitrifiers were specifically found in the water after the first steps of conventional treatment (i.e., DSF, SOF, and RSF, Figure 4.8) with different relative abundances. The OTUs were assigned to ammonium-oxidising bacteria (AOB, e.g., Nitrosomonas 6\%) and nitrite-oxidising bacteria (NOB, e.g., Candidatus Nitrotoga 1\% and Nitrospira 2-10\%). Conversely, none of them were found in RO-treated water except for a poorly documented OTU, namely, GOUTA6 belonging to AOB of Nitrosomonadaceae (Table 4.9). The absolute abundance of methanotrophs and nitrifiers after each treatment step is shown in Figure 4.11. The methanotrophs ranged from $3 \times 10^{3}-70 \times 10^{3} \mathrm{ICC} / \mathrm{mL}$, and the nitrifiers from $6 \times 10^{3}-$ $165 \times 10^{3} \mathrm{ICC} / \mathrm{mL}$, both of which were more abundant in treatment lines after oxygen was introduced.

Table 4.9. The classifications and relative abundances of methanotrophic and ammoniumoxidising OTUs found in samples.

\begin{tabular}{|c|c|c|c|c|c|c|c|c|c|c|c|c|}
\hline & Genus & $\begin{array}{l}\text { OTU } \\
\text { ID }^{*}\end{array}$ & AGW & DSF & SOF & RSF & ACF & UVD & CTW & IEX & $\mathrm{CC}$ & $\begin{array}{l}\text { site- } \\
\text { Remin }\end{array}$ \\
\hline \multirow{6}{*}{ 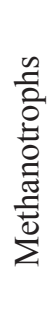 } & Methylovulum & 36 & $0 \%$ & $0 \%$ & $0 \%$ & $0 \%$ & $0 \%$ & $0 \%$ & $0 \%$ & $0 \%$ & $0 \%$ & $1 \%$ \\
\hline & uncultured & 37 & $0 \%$ & $0 \%$ & $0 \%$ & $0 \%$ & $0 \%$ & $0 \%$ & $0 \%$ & $0 \%$ & $0 \%$ & $2 \%$ \\
\hline & Methylobacter & 39 & $0 \%$ & $0 \%$ & $0 \%$ & $0 \%$ & $0 \%$ & $0 \%$ & $0 \%$ & $0 \%$ & $6 \%$ & $0 \%$ \\
\hline & Crenothrix & 51 & $0 \%$ & $0 \%$ & $2 \%$ & $0 \%$ & $0 \%$ & $0 \%$ & $0 \%$ & $0 \%$ & $3 \%$ & $0 \%$ \\
\hline & $\begin{array}{l}\text { uncultured } \\
\text { Methylomonaceae }\end{array}$ & 60 & $0 \%$ & $5 \%$ & $3 \%$ & $0 \%$ & $0 \%$ & $0 \%$ & $0 \%$ & $0 \%$ & $0 \%$ & $0 \%$ \\
\hline & Methyloglobulus & 119 & $0 \%$ & $0 \%$ & $2 \%$ & $0 \%$ & $0 \%$ & $0 \%$ & $0 \%$ & $0 \%$ & $0 \%$ & $0 \%$ \\
\hline \multirow{8}{*}{ 总 } & GOUTA6 & 32 & $0 \%$ & $0 \%$ & $0 \%$ & $0 \%$ & $0 \%$ & $0 \%$ & $0 \%$ & $0 \%$ & $54 \%$ & $5 \%$ \\
\hline & Nitrosomonas & 62 & $0 \%$ & $0 \%$ & $6 \%$ & $0 \%$ & $0 \%$ & $0 \%$ & $0 \%$ & $0 \%$ & $0 \%$ & $0 \%$ \\
\hline & MND1 & 116 & $0 \%$ & $0 \%$ & $0 \%$ & $0 \%$ & $2 \%$ & $0 \%$ & $3 \%$ & $0 \%$ & $0 \%$ & $0 \%$ \\
\hline & $\begin{array}{l}\text { Candidatus } \\
\text { Nitrotoga }\end{array}$ & 114 & $0 \%$ & $0 \%$ & $1 \%$ & $0 \%$ & $0 \%$ & $0 \%$ & $0 \%$ & $0 \%$ & $0 \%$ & $0 \%$ \\
\hline & $\begin{array}{l}\text { uncultured } \\
\text { Omnitrophicaeota }\end{array}$ & 81 & $0 \%$ & $0 \%$ & $0 \%$ & $0 \%$ & $2 \%$ & $0 \%$ & $2 \%$ & $0 \%$ & $0 \%$ & $0 \%$ \\
\hline & $\begin{array}{l}\text { uncultured } \\
\text { Omnitrophicaeota }\end{array}$ & 84 & $0 \%$ & $0 \%$ & $0 \%$ & $1 \%$ & $0 \%$ & $0 \%$ & $0 \%$ & $0 \%$ & $0 \%$ & $0 \%$ \\
\hline & Nitrospira & 54 & $0 \%$ & $7 \%$ & $10 \%$ & $2 \%$ & $0 \%$ & $0 \%$ & $0 \%$ & $0 \%$ & $0 \%$ & $0 \%$ \\
\hline & $\begin{array}{l}\text { uncultured } \\
\text { Nitrospirae }\end{array}$ & 69 & $4 \%$ & $3 \%$ & $0 \%$ & $0 \%$ & $0 \%$ & $0 \%$ & $0 \%$ & $0 \%$ & $0 \%$ & $0 \%$ \\
\hline
\end{tabular}

* As given in Table 4.8 
Multi-parametric assessment of biological stability of drinking water produced from groundwater: reverse osmosis vs. conventional treatment

There were several genera present in RO-treated water known for iron, manganese, and sulfur oxidation such as Sulfuricurvum (12\%), Ferritrophicum (5\%), Leptothrix (5\%), Geobacter (3\%), and Geothrix (2\%). Similarly, OTUs belonging to families of characterised iron-oxidisers (e.g., the Family Gallionellaceae), were found in the conventional treatment line.

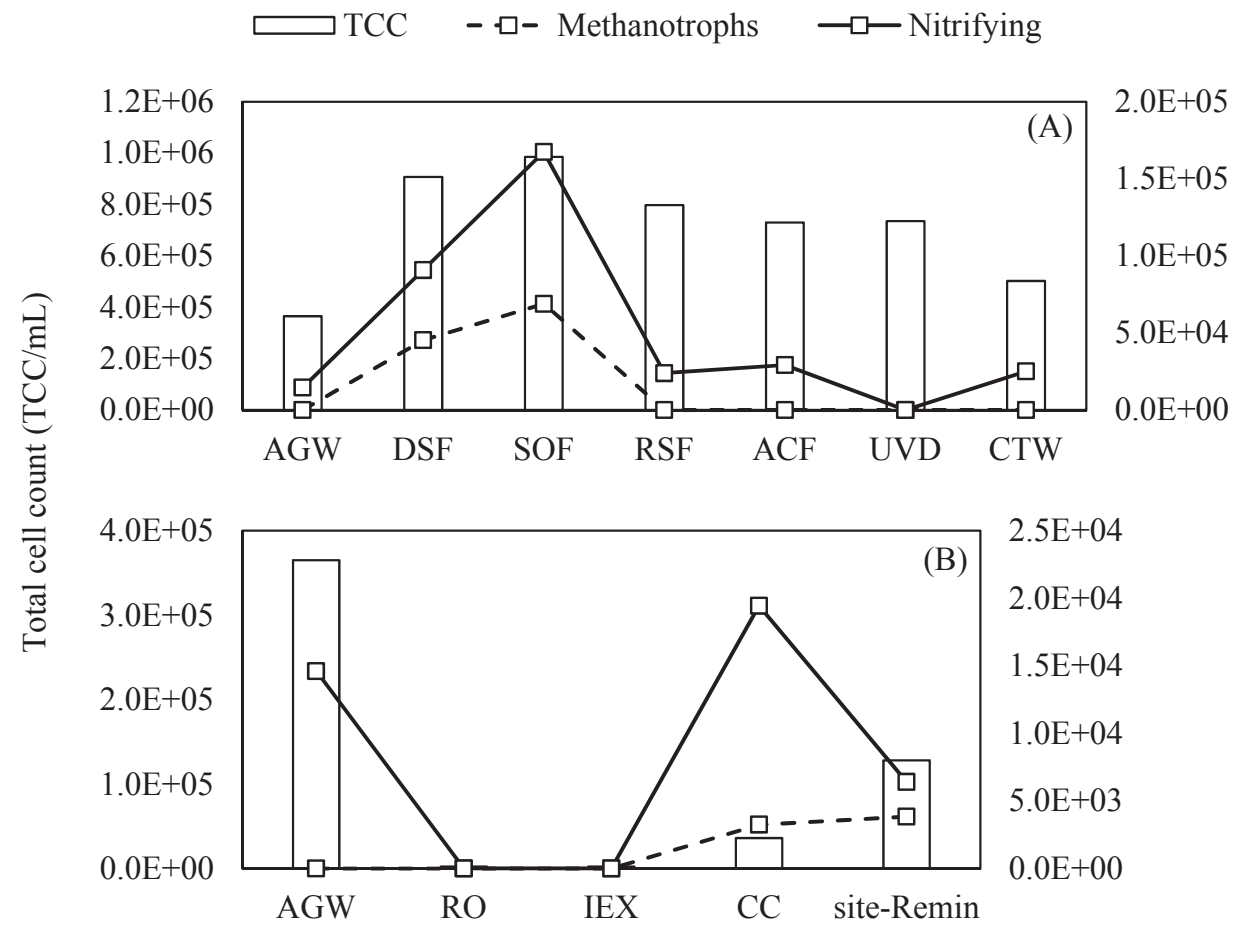

Figure 4.11. Total cell count (TCC) and the absolute abundance of methanotrophs and nitrifiers after each step in the conventional (A) and RO-based (B) treatment lines.

\subsubsection{Correlation between nutrients and microbiological parameters}

The influence of nutrients (LC-OCD fractions and phosphate) on microbiological parameters (ICC, ATP, and BGP) and community composition (OTUs with relative abundance $>0.5 \%$ ) was investigated using CCA. The results revealed that bacterial growth either within the treatment units (ICC and ATP) or at the laboratory (BGP) was strongly correlated to the concentration of DOC fractions, more specifically building blocks, humic substances, and neutrals, rather than phosphate (Figure 4.12A). The growth was not influenced by biopolymers and acids because their concentrations were below the reporting limit for all water samples. Regarding community composition (Figure 4.12B), about 50\% 
Multi-parametric assessment of biological stability of drinking water produced from groundwater: reverse osmosis vs. conventional treatment

of the dominant OTUs found in samples were strongly correlated to the concentration of building blocks, humic substances, and neutrals (group 1), whereas $23 \%$ were fairly well correlated to phosphate (group 2). However, no clear trend was observed with respect to which OTUs could grow on each nutrient fraction.

(A)
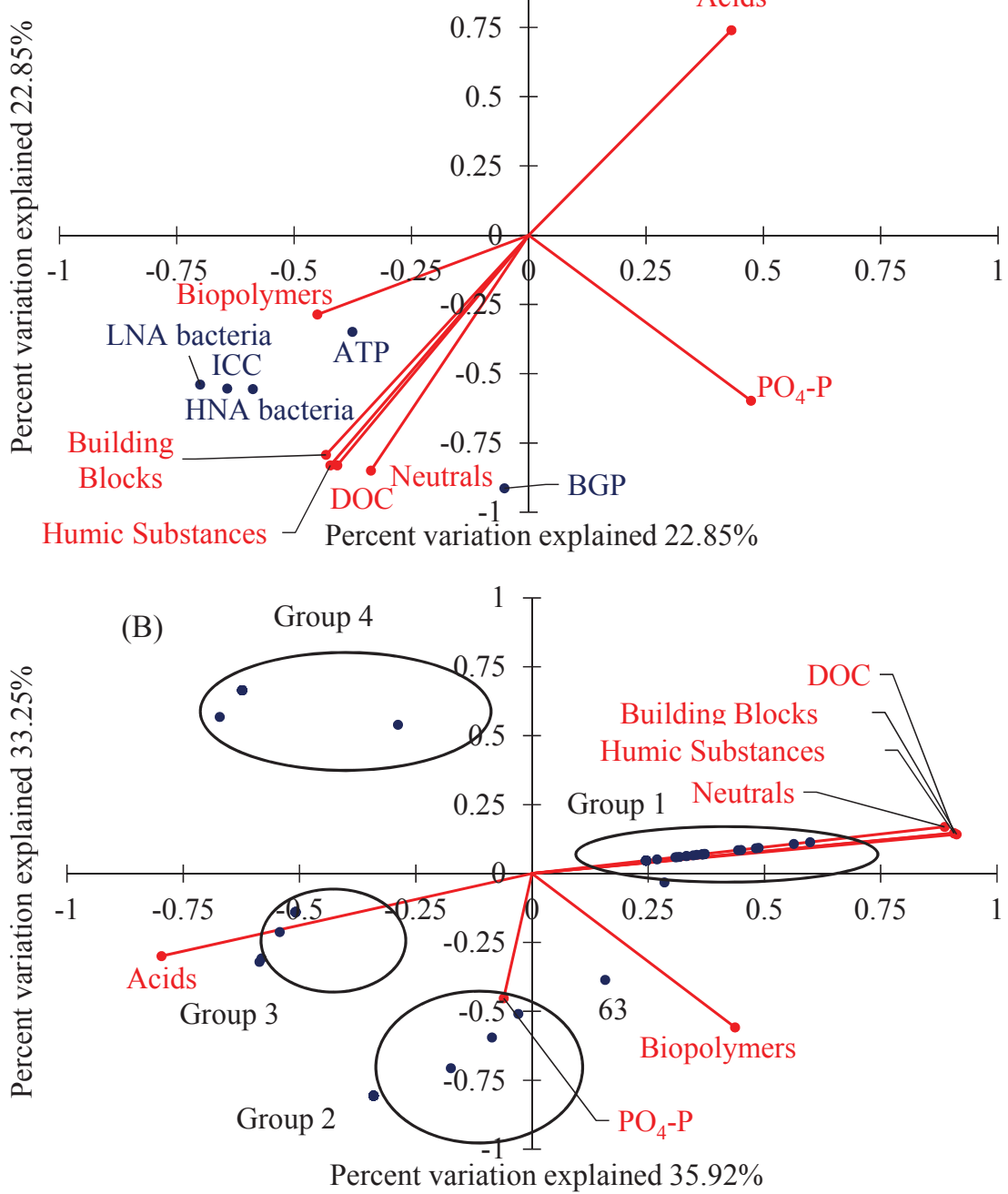

Figure 4.12. CCA ordination tri-plot representing variations in microbiological parameters (ICC, ATP, and BGP) (A) and community composition (OTUs with relative abundance $>0.5 \%$ ) (B) with respect to nutrient concentration (LC-OCD fractions and phosphate). OTUs of groups 1, 2, 3, and 4 are given in Table 4.10. 
Multi-parametric assessment of biological stability of drinking water produced from groundwater: reverse osmosis vs. conventional treatment

Table 4.10. OTUs ID per group displayed in Figure 4.12. The full taxonomy information of the OTUs is given in Table 4.8.

\begin{tabular}{|l|l|}
\hline Group & OTUs \\
\hline $\mathbf{1}$ & $52,53,54,55,56,57,58,59,60,61,64,65,67,68,69,70,71,72,73,74,75,76,77$, \\
& $\begin{array}{l}78,79,80,81,82,83,84,85,86,87,88,89,90,93,94,95,96,97,99,100,101,102, \\
\\
103,104,105,106,107,109,110,111,112,113,115,116,117,120\end{array}$ \\
\hline $\mathbf{2}$ & $\begin{array}{l}3,4,5,6,7,8,12,13,14,15,16,18,19,20,22,25,36,37,40,41,42,43,45,46,47, \\
48,50\end{array}$ \\
\hline $\mathbf{3}$ & $1,10,11,26,29,32,33,34,39,51$ \\
\hline $\mathbf{4}$ & $2,9,17,21,23,24,27,28,30,31,35,38,44,49$ \\
\hline
\end{tabular}

\subsection{Discussion}

The multi-parametric comparison approach applied in this study enabled better understanding of the microbiological water quality at different stages of the treatment. This approach included measuring several microbiological parameters and studying the relationship between them. The parameters included are the dynamics of bacterial load measured as numbers (cell count), bacterial activity (ATP concentration), and composition (16S rRNA gene sequencing) across treatment, as well as the growth potential of these bacteria in water (BGP) and the driving factors for this growth (nutrients). This multiparametric approach was used to compare conventionally and RO-treated drinking water as discussed below.

\subsubsection{Characterisations of bacterial cells: ICC, ATP and ATP per cell}

As quantified by cell count and ATP concentration, bacteria were better retained by the RO membrane ( $>99.6 \%$ removal), where the values in $\mathrm{RO}$ permeate were below the detection limit $\left(<10^{3} \mathrm{ICC} / \mathrm{mL} ;<0.1 \mathrm{ng} \mathrm{ATP} / \mathrm{L}\right)$. This complies with the fact that RO membrane is an effective barrier for microorganisms (Madaeni, 1999; Pype et al., 2016). However, this superior RO permeate quality could be influenced by the post-treatment processes (Sousi et al., 2018), which was also observed in the present study as increased ICC and ATP after the pilot-scale remineralisation (calcite contactors) and tower aeration units. The deterioration of biological water quality could be attributed to practical factors, such as bacteria sloughing off the surface biofilm of calcite grains and/or packing material filling the aeration tower.

Interestingly, it is noticed that the increase in ATP was particularly correlated to the increased percentage of HNA bacteria within ICC for both RO-treated water $\left(\mathrm{R}^{2}=0.77\right)$ and conventional treatment $\left(\mathrm{R}^{2}=0.65\right)$, which agrees with previous findings (Siebel et al., 2008; Liu et al., 2013b) and can be attributed to the high activity and large cell size of HNA bacteria (Lebaron et al., 2001; Proctor et al., 2018). The changes in HNA bacteria and ATP 
Multi-parametric assessment of biological stability of drinking water produced from groundwater: reverse osmosis vs. conventional treatment

across the treatment lines can be explained by the nature of treatment applied. For instance, the highest removal of HNA bacteria by the conventional treatment line $(\sim 30 \%)$ occurred within the rapid sand filters, where physical retention of larger bacterial cells is more efficient (Vital et al., 2012; Fujioka et al., 2019) and significant ATP reduction could be obtained (Liu et al., 2013b).

Regarding the calculated ATP per cell, the obtained values (ranging from $0.70 \times 10^{-17}$ $11.32 \times 10^{-17} \mathrm{~g} \mathrm{ATP} /$ cell) were in line with previous findings of Hammes et al. (2010b) for different aquatic environments (average; $1.75 \times 10^{-10} \mathrm{nmol} / \mathrm{cell}$ equivalent to $8.89 \times 10^{-17} \mathrm{~g}$ ATP/cell), but lower than reported values for bacteria growing under starvation condition (up to $30 \times 10^{-17} \mathrm{~g} \mathrm{ATP/cell)} \mathrm{(Webster} \mathrm{et} \mathrm{al.,} \mathrm{1985).} \mathrm{The} \mathrm{latter} \mathrm{value} \mathrm{was} \mathrm{obtained} \mathrm{for}$ specific bacterial species and might not be applicable to others, and these values were calculated based on heterotrophic plate count, which would significantly underestimate the cell count and result in higher ATP per cell values (van Nevel et al., 2017).

Comparing the two treatment lines in the present study, the ATP per cell of the post-treated RO permeate was $>5$ times higher than that of conventionally treated water $\left(9.07 \times 10^{-17} \mathrm{vs}\right.$. $1.71 \times 10^{-17} \mathrm{~g} \mathrm{ATP} /$ cell). This could be partially explained by the percentage of large and active cells (i.e., HNA bacteria) in each water type ( $>85 \%$ vs. $\sim 40-45 \%$ ). Nonetheless, the low ATP per cell for the conventionally treated water was in line with previously reported values for water after granular activated carbon filtration (Magic-Knezev and van der Kooij, 2004). Moreover, the composition of bacterial communities present in water could influence ATP per cell values (Eydal and Pedersen, 2007). As confirmed by the bacterial community analysis, members of the Patescibacteria, which (remarkably) pass $0.2 \mu \mathrm{m}$ and even $0.1 \mu \mathrm{m}$ filters (Herrmann et al., 2019), were more abundant in conventionally treated water (20$60 \%)$ than in post treated RO permeate $(<5 \%)$. On the other hand, members of Proteobacteria and Bacteroidetes, that are generally known for large cell size based on FCM findings (Proctor et al., 2018), accounted for $75-85 \%$ of bacterial communities in ROtreated water.

\subsubsection{BGP and the factors driving bacterial growth (nutrients)}

The present study also confirmed the effectiveness of RO filtration in controlling the BGP of water because of its high efficiency of nutrient removal $(>97 \%$ carbon, $>99.5 \%$ phosphate), which complies with previous studies (Jacobson et al., 2009; Park and Hu, 2010; Thayanukul et al., 2013). Though the post RO treatment caused an increase in BGP, the $\mathrm{BGP}$ of RO-treated water was still lower than that of conventionally treated water by a factor of 4 . As reported in a recent study with the same water, $\sim 10$ times lower biofilm formation potential (BFP) was found for RO-based treatment compared with that of conventionally treated water (Learbuch et al., 2019), indicating even higher efficiency in controlling biofilm formation by RO filtration and possibly different growth dynamics between planktonic bacteria and biofilm. 
Multi-parametric assessment of biological stability of drinking water produced from groundwater: reverse osmosis vs. conventional treatment

The increased BGP after post-treatment can be attributed to the introduction of growthpromoting nutrients during those processes, as confirmed by phosphate measurement which increased more than 7 times (from $<1$ to $7 \mu \mathrm{g} / \mathrm{L} \mathrm{PO}_{4}-\mathrm{P}$ ) after calcite contactors. As demonstrated by the nutrient limitation tests, the P-limited BGP of site post-treated RO permeate was higher than that of lab post-treated RO permeate and conventionally treated water $\left(2,089 \times 10^{3}\right.$ vs. $1,144 \times 10^{3}$ vs. $\left.1,383 \times 10^{3} \mathrm{ICC} / \mathrm{mL}\right)$, confirming again the higher phosphate concentration in site post-treated RO permeate (compared with lab-Remin and CTW) introduced by calcite contactors.

Though the introduction of carbon was not detectable using LC-OCD analysis since the concentrations both before and after the post-treatment were below the reporting limit, it was confirmed by the nutrient limitation tests, where carbon was the growth-limiting nutrient before and after the post-treatment regardless of the BGP value. The carbon limitation has been commonly found in many types of water (Huck, 1990; Hu et al., 1999; van der Kooij, 2000; Liu et al., 2015; Prest et al., 2016a), as observed also for water types tested in this study even when the phosphate concentration was very low $\left(<1 \mu \mathrm{g} / \mathrm{L} \mathrm{PO}_{4}-\mathrm{P}\right)$. Moreover, the carbon limitation in all samples was confirmed with the canonical correspondence analysis (CCA) without identifying which carbon fraction was the most relevant for growth, where a previous study showed that these bacteria could grow on carbon with different molecular characteristics ranging from readily available to more complex organic carbon (Sousi et al., 2020b). Similarly, the link between the presence of different OTUs and carbon fractions needs to be further explored.

\subsubsection{Shifts in bacterial communities}

The present study showed that both the diversity and composition of bacterial communities were largely influenced by water treatment processes, which complies with previous studies on different drinking water treatment processes (Ivone et al., 2013; Liao et al., 2015; Li et al., 2017a; Liu et al., 2018). Since RO filtration could effectively remove bacteria present in source water, the developed bacterial community in post-treated RO permeate was completely different from the source. This can be used as a control for the observations in the conventional treatment scheme. For example, RO filtration completely removed the dominant phyla (i.e., Nitrospirae and Omnitrophicaeota) from source anaerobic groundwater. However, only the strictly anaerobic members of the Nitrospirae, e.g., Thermodesulfovibrionia (Garrity et al., 2001), were effectively removed in the very first conventional treatment step (i.e., DSF). Similarly, the relative abundance of the Omnitrophicaeota decreased across the conventional treatment line because most of the species within this phylum were anaerobic, which could not survive in oxygen-rich fresh water (Rivas-Marín and Devos, 2018).

Moreover, it is interesting to observe the shifts in methane-oxidising bacteria (MOB), ammonium-oxidising bacteria (AOB) and nitrite-oxidising bacteria (NOB) across the 
Multi-parametric assessment of biological stability of drinking water produced from groundwater: reverse osmosis vs. conventional treatment

treatment lines. The high concentration of $\mathrm{CH}_{4}(2-4 \mathrm{mg} / \mathrm{L})$ in source groundwater and the introduction of oxygen during aeration contributed to the presence of MOB in both conventional and RO-based treatment schemes (Nicol et al., 2003; DiSpirito et al., 2016). Only type I methanotrophs were detected (e.g., Methylovulum spp., Methylobacter spp., and Methyloglobulus spp.), which is typical for drinking water (Lipponen et al., 2004). The presence of only type I methanotrophs indicates that the residence time of methane within the aeration towers was short, as those bacteria are known to rapidly oxidise methane in an oxygen-rich environment (Graham et al., 1993; Hanson and Hanson, 1996). Since methane is the sole carbon source for these bacteria, their presence in the DSF and SOF treatment steps indicates that methane was considerably removed in these treatment units, resulting in $\sim 20 \mu \mathrm{g} / \mathrm{L} \mathrm{CH}_{4}$ in the following conventional treatment steps.

The nitrification activity within the conventional treatment line was clearly higher than that in the RO-based line. For example, the AOB (e.g., Nitrosomonas spp.) and NOB (e.g., Candidatus Nitrotoga spp., Nitrospira spp.) (Prosser et al., 2014; Koch et al., 2015; Kitzinger et al., 2018) were detected in conventional treatment units (DFS, SOF, and RSF), but not in the RO-based scheme. The same observation was confirmed by the complete oxidation of ammonium present in source groundwater $(2.90 \pm 0.10 \mathrm{mg}-\mathrm{N} / \mathrm{L})$ to nitrate in the conventionally treated water $(2.77 \pm 0.40 \mathrm{mg}-\mathrm{N} / \mathrm{L})$ (Table 2$)$. Whereas the nitrification activity within the RO-based treatment scheme was minimal, where AOB and NOB were absent because the ammonium was physically retained by RO membrane (to $0.17 \mathrm{mg}-\mathrm{N} / \mathrm{L}$ ), and further absorbed by post ion exchange $(<0.02 \mathrm{mg}-\mathrm{N} / \mathrm{L})$ without conversion to nitrate. Lastly, the presence of several bacterial genera in RO-treated water that are known to be involved in the oxidation of iron, manganese, and sulfur, e.g., Sulfuricurvum, Ferritrophicum, Leptothrix, Geobacter, and Geothrix (Hedrich et al., 2011; Schmidt et al., 2014), indicates that these metals were re-introduced during post-treatment. Nonetheless, the presence of such genera in conventionally treated anaerobic groundwater (e.g., the Family Gallionellaceae) has been previously reported (Hallbeck and Pedersen, 2014).

\subsubsection{Practical insights for managing microbiological water quality}

Despite the influences of post-treatment on the quality of RO permeate, the finished ROtreated water had much lower cell count and BGP compared with conventionally treated water. To mitigate the negative influences of post-treatment, it is recommended to use high quality calcite grains for remineralisation to prevent the introduction of organic and inorganic nutrients. Furthermore, aeration towers should be maintained and cleaned more frequently to reduce bacterial growth on the packing material. It should be noted that the current study was conducted with groundwater and the sampling period did not cover the whole seasons. The observations might be different for surface water systems subjected to significant seasonal variations, for which a sampling program including different seasons is 
Multi-parametric assessment of biological stability of drinking water produced from groundwater: reverse osmosis vs. conventional treatment

high recommended. Though the effect of seasonal variations on the analysed parameters was beyond the focus of this study, negative influences of post-treatment were previously demonstrated throughout the year (Sousi et al., 2020b).

The multi-parametric evaluation discussed above offered an integral understanding of the stability and changes in microbiological water quality between two treatment lines considering the bacterial quantity and activity, nutrient concentration and composition as well as bacterial community composition and diversity. Beyond the simple number of cells and/or bioactivity, the comprehensive dataset obtained in this study allows in-depth assessment of which bacteria are growing and why in each step of the treatment process. Besides regular monitoring, the methodology proposed is especially useful when water quality deteriorates during treatment and remedial actions are required to manage biological water quality. Although multi-parametric monitoring is expensive, it is recommended as a complementary approach when water quality deterioration is detected during regular monitoring.

For the microbiology of drinking water distribution system, attributed to its high efficiency in removing nutrients, the RO-based treatment will be useful in controlling the growth of both planktonic bacteria and biofilm. Regarding the microbes, the comparison between conventional and RO-based treatment demonstrated the possible quantitative and qualitative control of drinking water microbiology by using RO membranes as an absolute barrier for cells. Considering produced water is the seed for the microbes to thrive in water, biofilm, and loose deposits in the downstream drinking water distribution system (Liu et al., 2018), it could be a reasonable vision to manage the microbial ecology of drinking water distribution systems by introducing probiotic microbes, rather than microbial contamination, through post RO treatment to occupy the niches and form a predictable and predefined microbial ecology. 
Multi-parametric assessment of biological stability of drinking water produced from groundwater: reverse osmosis vs. conventional treatment

\subsection{Conclusions}

The following conclusions can be drawn based on this study:

- RO filtration significantly reduced the BGP of source groundwater to an extremely low level of $50 \pm 12 \times 10^{3} \mathrm{ICC} / \mathrm{mL}$ in lab-remineralised RO permeate, which increased again to $130 \pm 10 \times 10^{3} \mathrm{ICC} / \mathrm{mL}$ when RO permeate underwent site posttreatment.

- Despite this increase, the BGP of post-treated RO permeate was $>75 \%$ lower than that of conventionally treated water $\left(130 \pm 10 \times 10^{3}\right.$ vs. $450 \times 10^{3}-550 \times 10^{3}$ $\mathrm{ICC} / \mathrm{mL})$.

- Carbon was the bacterial growth-limiting nutrient for both RO-treated and conventionally treated water. Phosphate did not limit bacterial growth even at very low concentrations $(<1 \mu \mathrm{g} / \mathrm{L}$ PO4-P).

- The type of water treatment shaped the bacterial community of the finished treated water. Some genera were shared between source anaerobic groundwater and conventionally treated water, whereas the bacterial genera in post-treated RO permeate were mainly introduced during post-treatment.

- Beyond quantitative assessment, the multi-parametric approach suggested in this study is useful in understanding and managing microbiological water quality in drinking water treatment and distribution systems. 



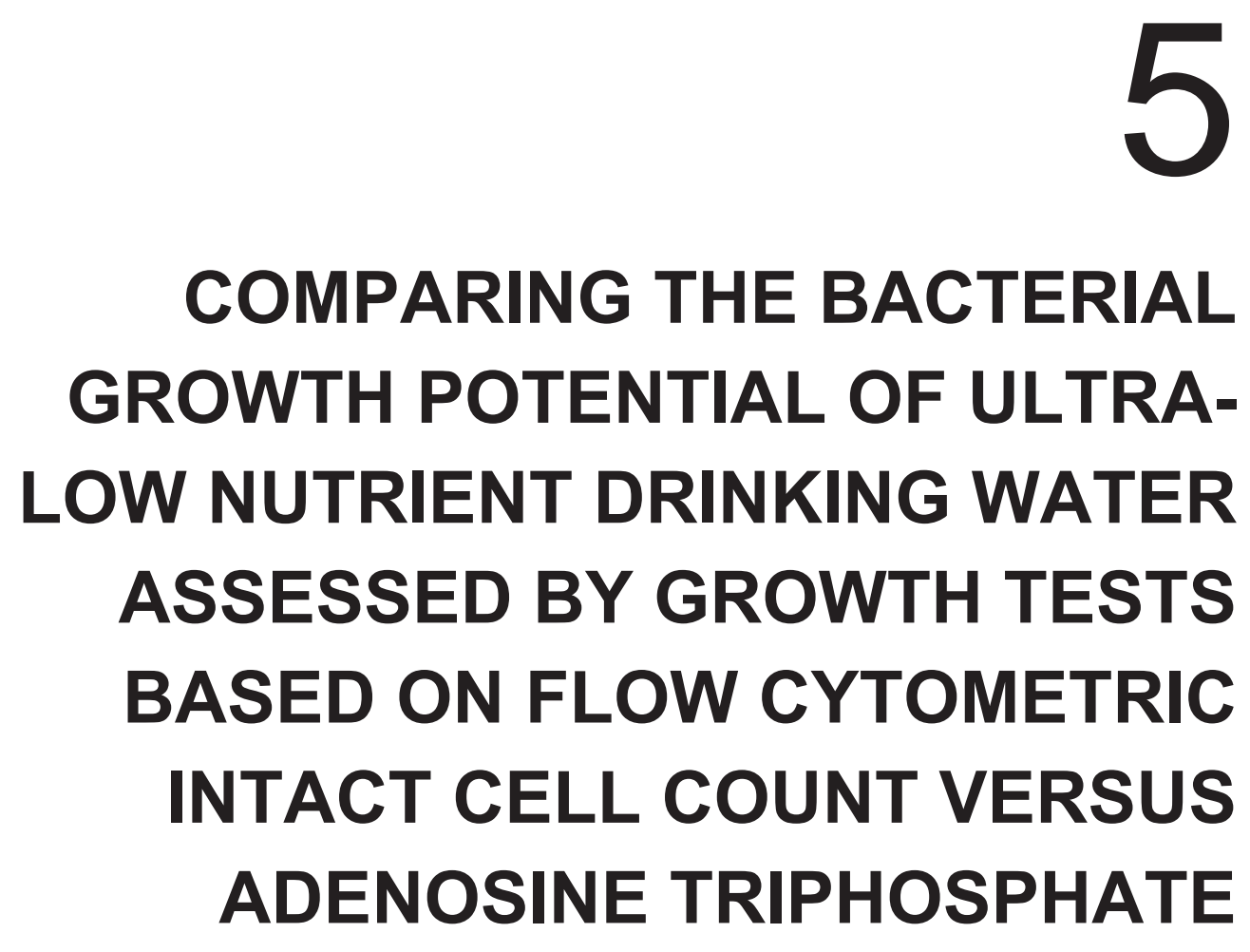

This chapter is based on the following publication:

Sousi, M., Salinas-Rodriguez, S.G., Liu, G., Dusseldorp, J., Kemperman, A.J.B., Schippers, J.C., van der Meer, W.G.J., Kennedy, M.D., 2021. Comparing the bacterial growth potential of ultra-low nutrient drinking water assessed by growth tests based on flow cytometric intact cell count versus adenosine triphosphate. Water Research 203, 117506. https://doi.org/10.1016/j.watres.2021.117506 
Comparing the bacterial growth potential of ultra-low nutrient drinking water assessed by growth tests based on flow cytometric intact cell count versus adenosine triphosphate

\section{Abstract}

The bacterial growth potential (BGP) of drinking water is widely assessed either by flow cytometric intact cell count (BGPICC) or adenosine triphosphate (BGPATP) based methods. Combining BGPICC and $\mathrm{BGP}_{\mathrm{ATP}}$ measurements has been previously applied for various types of drinking water having high to low growth potential. However, this has not been applied for water with ultra-low nutrient content, such as remineralised RO permeate. To conduct a sound comparison, conventionally treated drinking water was included in this study, which was also used as an inoculum source. BGPICC, BGP ATP, intact cell-yield (YICC), and ATP-yield ( $\left.\mathrm{Y}_{\text {ATP }}\right)$ were determined for conventionally treated drinking water (Tapwater) and remineralised RO permeate (RO-water). In addition, both BGPICC and BGPATP methods were used to identify the growth-limiting nutrient in each water type. The results showed that the BGPICC ratio between Tap-water/RO-water was $\sim 7.5$, whereas the BGPATP ratio was only $\sim 4.5$. Moreover, the YICC ratio between Tap-water/RO-water was $\sim 2(9.8 \pm$ $0.6 \times 10^{6}$ vs. $4.6 \pm 0.8 \times 10^{6}$ cells $\left./ \mu g-C\right)$, whereas the $\mathrm{Y}_{\text {ATP }}$ ratio was $\sim 1(0.39 \pm 0.12$ vs. $0.42 \pm 0.06 \mathrm{ng} \mathrm{ATP} / \mu \mathrm{g}-\mathrm{C})$, resulting in a consistently higher ATP per cell in RO-water than that of Tap-water. Both BGPICC and BGP ATP methods revealed that carbon was the growthlimiting nutrient in the two types of water. However, with the addition of extra carbon, phosphate limitation was detected only with the BGPICC method, whereas BGPATP was not affected, suggesting that a combination of carbon and phosphate is essential for biomass synthesis, whereas carbon is probably utilised for cellular activities other than cell synthesis when phosphate is limited. It was estimated that the intact cell-yield growing on phosphate would be $0.70 \pm 0.05 \times 10^{9}$ cells $/ \mu \mathrm{g} \mathrm{PO}_{4}-\mathrm{P}$

\subsection{Introduction}

Delivering safe and biologically stable potable water is the aim of drinking water utilities worldwide. Biologically stable drinking water is especially important for non-chlorinated drinking water distribution systems (van der Kooij and Veenendaal, 2014) to limit bacterial growth that might take place during transport and distribution. Traditionally, biological stability is assessed by the available nutrients to support bacterial growth in water, namely biodegradable dissolved organic carbon (BDOC) (Servais et al., 1987; Huck, 1990) and assimilable organic carbon (AOC) (van der Kooij et al., 1982; Hammes and Egli, 2005). In addition to nutrient measurement, biological stability has been recently assessed by direct measurement of the bacterial growth potential (BGP) of water, which is defined as the level of bacterial growth that can occur in water samples under predefined conditions in the laboratory (Prest et al., 2016a).

The BGP can be measured based on cell count by flow cytometry (FCM) or adenosine triphosphate (ATP) by luminometer under various environmental conditions (Prest et al., 2016b; Nescerecka et al., 2018). FCM is a rapid bacterial quantification tool based on 
Comparing the bacterial growth potential of ultra-low nutrient drinking water assessed by growth tests based on flow cytometric intact cell count versus adenosine triphosphate

fluorescence staining of total and intact cells, while ATP is the energy currency of all living cells measured based on bioluminescence analysis, which is an indicator of viability (Abushaban et al., 2019). BGP assessment by FCM or ATP overcomes the limitations of the traditional biological stability assessment methods that are based on plate counting, in terms of rapidity, accuracy, and laborious demands (Hammes et al., 2010b; Prest et al., 2016b; van Nevel et al., 2017). However, there are no guidelines based on FCM or ATP as these parameters are still used for research purposes. Moreover, FCM and ATP measurements are beneficial for the complete detection of bacterial cells in water, allowing for using a natural bacterial inoculum for BGP tests to ensure the consumption of a wider range of organic compounds present in the water (Hammes and Egli, 2005).

Several studies have used both FCM and ATP in field-testing for monitoring water quality in treatment plants and distribution systems (Vital et al., 2012; Farhat et al., 2018), where the relationship between instant FCM and ATP measurements has been investigated. By measuring BGP of different water types, Farhat et al. (2018) found that ATP and FCM results did not show the same trend due to the nature of each method, where ATP measures variable energy carrier compounds within cells, while FCM measures the numerical growth of bacteria. Based on these observations, the authors suggested combining both methods for more insight into bacterial growth potential. However, the reason behind the different BGP trends with FCM and ATP and the interpretation of this difference still need further investigation for conventional drinking water and more especially for ultra-low nutrient drinking water such as remineralised reverse osmosis (RO) permeate. The latter water type is the focus of this study where a very low BGP has been reported for drinking water produced by RO-based treatment (Sousi et al., 2018).

Therefore, the objective of this study was to combine the outcome of BGP obtained by FCM intact cell count (BGPICC) with that by ATP (BGPATP). Two water types were used to conduct this comparison, namely: conventionally treated drinking water with a relatively high nutrient content versus ultra-low nutrient water produced by RO-based treatment (RO and remineralisation). The comparison included the ratio between the BGPICC and BGP ATP of these types of water, as well as the ratio between intact cell-yield (YICC) and ATP-yield (Y water type with both BGPICC and BGPATP.

\subsection{Materials and methods}

\subsubsection{Water samples}

This study was conducted at the Oasen drinking water treatment plant located in Kamerik, the Netherlands, which supplies $340 \mathrm{~m}^{3} / \mathrm{h}$ of drinking water. The detailed description of treatment and water quality is given in Sousi et al. (2020a). In short, the plant currently treats anaerobic groundwater by conventional means comprising dry sand filtration (rapid sand 
Comparing the bacterial growth potential of ultra-low nutrient drinking water assessed by growth tests based on flow cytometric intact cell count versus adenosine triphosphate

filters fed with spray aerated water), pellet softening, rapid sand filtration, activated carbon filtration, and UV disinfection. The finished conventionally treated drinking water (Tapwater) is stored in the clean water reservoir, from which samples were collected during this study. A pilot-scale advanced treatment scheme $\left(7 \mathrm{~m}^{3} / \mathrm{h}\right)$ is installed at the same location to treat anaerobic groundwater directly by reverse osmosis (RO) with a total recovery of $75 \%$. Thereafter, RO permeate is post-treated with ion exchange, remineralisation by calcite contactors, magnesium dosing, and tower aeration. Additional details about the conventional and RO-based water treatment schemes can be found in Table 5.1.

Table 5.1. The detailed configurations of the conventional and RO-based treatment lines at the drinking water treatment plant.

\begin{tabular}{|c|c|c|}
\hline & Treatment step & Details \\
\hline \multirow{7}{*}{ 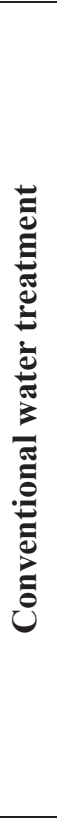 } & Dry sand filtration & $\begin{array}{l}5 \text { units ( } 2 \mathrm{~m} \text { bed height, } 28 \mathrm{~m}^{2} \text { surface area) } \\
\text { Residence time } \sim 2.5-5 \mathrm{~min} \\
\text { Backwash: every } 48 \text { hours, } 20 \mathrm{~min} \text { cycle, } 250 \mathrm{~m}^{3} \text { volume }\end{array}$ \\
\hline & Tower aeration & $\begin{array}{l}2 \text { units ( } 3 \mathrm{~m} \text { height, } 2.5 \mathrm{~m}^{2} \text { surface area) } \\
\text { Packing material: Pall-rings, } 100 \mathrm{~mm} \\
\text { Co-current air flow } \\
\text { RQ } \sim 5-10\end{array}$ \\
\hline & Pellet softening & $\begin{array}{l}4 \text { units ( } 5 \mathrm{~m} \text { height, } 1.4 \mathrm{~m}^{2} \text { surface area) } \\
\text { Residence time } \sim 5.5 \mathrm{~min} \\
\text { Chemical: } \mathrm{NaOH}(\mathrm{pH} \sim 8.5-10) \\
\text { Sand grains: } 0.15-0.40 \mathrm{~mm}\end{array}$ \\
\hline & Submerged sand filtration & $\begin{array}{l}3 \text { units }\left(2 \mathrm{~m} \text { bed height, } 18 \mathrm{~m}^{2} \text { surface area }\right) \\
\text { Hydraulic retention time } \sim 21 \mathrm{~min} \\
\text { Backwash: every } 60 \text { hours, } 15 \mathrm{~min} \text { cycle, } 100 \mathrm{~m}^{3} \text { volume }\end{array}$ \\
\hline & $\begin{array}{l}\text { Granular activated carbon } \\
\text { filtration }\end{array}$ & $\begin{array}{l}3 \text { units ( } 2 \mathrm{~m} \text { bed height, } 10 \mathrm{~m}^{2} \text { surface area) } \\
\text { Residence time } \sim 12-15 \mathrm{~min} \\
\text { Regeneration: Every } 37,500 \mathrm{~m}^{3} / \mathrm{m}^{3} \text { bed volume }\end{array}$ \\
\hline & UV disinfection & $\begin{array}{l}\text { Medium-pressure UV unit } \\
\text { UV dose }=20 \mathrm{~mJ} / \mathrm{cm}^{2}\end{array}$ \\
\hline & Clean water reservoir & Total volume $=7,430 \mathrm{~m}^{3}$ \\
\hline \multirow{4}{*}{ 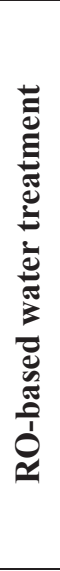 } & RO filtration & $\begin{array}{l}\text { Total recovery }=75 \% \\
3 \text { filtration stages: } 9,3 \text {, and } 1 \text { pressure vessels } \\
3 \text { elements per vessel } \\
\text { Membrane surface area }=7.43 \mathrm{~m}^{2} \\
\text { Feed water pre-treatment: cartridge filter }\end{array}$ \\
\hline & Ion exchange & $\begin{array}{l}\text { LEWATIT S } 2568 \text { synthetic cation resin } \\
\text { Volume }=0.70 \mathrm{~m}^{3} \\
\text { Residence time } \sim 1.5-2.25 \mathrm{~min}\end{array}$ \\
\hline & Remineralisation & $\begin{array}{l}\text { calcite contactors } \\
\mathrm{EBCT} \sim 15-20 \mathrm{~min}\end{array}$ \\
\hline & Tower aeration & $\begin{array}{l}2 \text { units (Volume }=1.24 \mathrm{~m}^{3} \text { ) } \\
\text { Packing material: } 38-8 \text { plastic Raflux-Rings, } 15 \mathrm{~mm} \\
\text { Counter-current air flow } \\
\text { Ratio of air to water flow (RQ) } \sim 10-15\end{array}$ \\
\hline
\end{tabular}


Comparing the bacterial growth potential of ultra-low nutrient drinking water assessed by growth tests based on flow cytometric intact cell count versus adenosine triphosphate

The blank was prepared by correcting the mineral content of water collected directly after RO filtration (i.e., RO permeate) at the laboratory using ultrapure chemical stock solutions, where the final concentrations were as follows: $\mathrm{NaHCO}_{3}\left(\mathrm{pH}\right.$ of $7.8 \pm 0.2,122 \mathrm{mg} / \mathrm{L} \mathrm{HCO}_{3}{ }^{-}$), $\mathrm{CaCl}_{2}\left(40 \mathrm{mg} / \mathrm{L} \mathrm{Ca}^{2+}\right)$, and $\mathrm{MgCl}_{2}\left(4 \mathrm{mg} / \mathrm{L} \mathrm{Mg}^{2+}\right)$. The blank (laboratory-remineralised $\mathrm{RO}$ permeate) is denoted as RO-water. The water quality analysis of Tap-water and RO-water, including LC-OCD analysis and AOC determined according to van der Kooij et al. (1982), is shown in Table 5.2. The cell count in RO permeate $\left(2 \times 10^{3}\right.$ total cells $/ \mathrm{mL}$ and $10^{3}$ intact cells $/ \mathrm{mL}$ ) was lower than that reported in other studies (Dixon et al., 2012; Thayanukul et al., 2013; Buysschaert et al., 2018; Fujioka et al., 2018), which might be attributed to the anaerobic operation of RO in this study that resulted in limited bacterial growth on RO membranes, or different methods used for cell counting.

Table 5.2. The properties of conventionally treated water (Tap-water) and laboratoryremineralised RO permeate (RO-water).

\begin{tabular}{|c|c|c|}
\hline Parameter & Tap-water & RO-water \\
\hline $\mathrm{T}\left({ }^{\circ} \mathrm{C}\right)$ & 11.8 & 12.7 \\
\hline $\mathrm{pH}$ & 8.1 & 7.8 \\
\hline Turbidity (FTE) & $<0.1-0.4$ & $<0.1-0.3$ \\
\hline $\mathrm{O}_{2}\left(\mathrm{mg} \mathrm{O}_{2} / \mathrm{L}\right)$ & 8.3 & 9.1 \\
\hline SI & $-0.07-0.18$ & $-4.38-0.23$ \\
\hline Total hardness $(\mathrm{mmol} / \mathrm{L})$ & 1.2 & 1.1 \\
\hline Conductivity (mS/m) & 63.2 & 20.9 \\
\hline Bicarbonate $\left(\mathrm{mg} \mathrm{HCO}_{3} / \mathrm{L}\right)$ & 219.5 & 132.2 \\
\hline $\mathrm{Cl}(\mathrm{mg} \mathrm{Cl} / \mathrm{L})$ & 74.6 & n.a. \\
\hline $\mathrm{F}(\mathrm{mg} \mathrm{F} / \mathrm{L})$ & 0.1 & $<0.02$ \\
\hline $\mathrm{Al}(\mu \mathrm{g} \mathrm{Al} / \mathrm{L})$ & 3.8 & $<2$ \\
\hline $\mathrm{SO}_{4}\left(\mathrm{mg} \mathrm{SO}_{4} / \mathrm{L}\right)$ & 50.7 & n.a. \\
\hline $\mathrm{Na}(\mathrm{mg} \mathrm{Na} / \mathrm{L})$ & 101.6 & n.a. \\
\hline $\mathrm{Fe}(\mathrm{mg} \mathrm{Fe} / \mathrm{L})$ & 0.01 & n.a. \\
\hline $\mathrm{Mg}(\mathrm{mg} \mathrm{Mg} / \mathrm{L})$ & 15.5 & 3.5 \\
\hline $\mathrm{Mn}(\mathrm{mg} \mathrm{Mn} / \mathrm{L})$ & $<0.005$ & $<0.005$ \\
\hline $\mathrm{Ca}(\mathrm{mg} \mathrm{Ca} / \mathrm{L})$ & 22.7 & 40.4 \\
\hline Ortho $\mathrm{P}\left(\mu \mathrm{g} / \mathrm{L} \mathrm{PO}_{4}-\mathrm{P}\right)$ & $<1.0$ & $<1.0$ \\
\hline AOC P17, NOX ( $\mu \mathrm{g} / \mathrm{L}$ Ac-C) & $4.2 \pm 0.3$ & $3.8 \pm 0.2$ \\
\hline $\mathrm{DOC}(\mu \mathrm{g} \mathrm{C} / \mathrm{L})$ & 5980 & $<200$ \\
\hline Biopolymers $(\mu \mathrm{g}-\mathrm{C} / \mathrm{L})$ & $<100$ & $<100$ \\
\hline Humic substances $(\mu \mathrm{g}-\mathrm{C} / \mathrm{L})$ & 4260 & $<200$ \\
\hline Building blocks $(\mu \mathrm{g}-\mathrm{C} / \mathrm{L})$ & 969 & $<200$ \\
\hline Neutrals $(\mu \mathrm{g}-\mathrm{C} / \mathrm{L})$ & 764 & $<200$ \\
\hline Acids & $<200$ & $<200$ \\
\hline $\mathrm{NH}_{4}(\mathrm{mg} \mathrm{N} / \mathrm{L})$ & $<0.02$ & $<0.02$ \\
\hline $\mathrm{NO}_{2}(\mathrm{mg} \mathrm{N} / \mathrm{L})$ & $<0.003$ & $<0.003$ \\
\hline $\mathrm{NO}_{3}(\mathrm{mg} \mathrm{N} / \mathrm{L})$ & 2.89 & 0.23 \\
\hline Total cell count by FCM $\left(\times 10^{3}\right.$ cells $\left./ \mathrm{mL}\right)$ & $740 \pm 93$ & $2 \pm 0.5$ \\
\hline Intact cell count by FCM $\left(\times 10^{3}\right.$ cells $\left./ \mathrm{mL}\right)$ & $539 \pm 58$ & $1 \pm 0.3$ \\
\hline
\end{tabular}


Comparing the bacterial growth potential of ultra-low nutrient drinking water assessed by growth tests based on flow cytometric intact cell count versus adenosine triphosphate

\subsubsection{Bacterial growth potential (BGP) test}

The bacterial growth potential (BGP) of water was measured according to Sousi et al. (2018). In short, samples of Tap-water and RO-water were collected in AOC-free glassware that is treated at $550^{\circ} \mathrm{C}$ for $6 \mathrm{~h}$. Thereafter, samples were pre-treated at the laboratory by pasteurisation $\left(70{ }^{\circ} \mathrm{C}\right.$ for $30 \mathrm{~min}$ ) to inactivate indigenous bacteria before inoculating with $\sim 10^{4} \mathrm{ICC} / \mathrm{mL}$ (ICC: intact cell count) of a natural bacteria consortium originating from Tapwater, where using RO permeate bacteria as an inoculum is not recommended due to their limited ability to consume complex organic carbon (Sousi et al., 2020b). Pre-treated samples were distributed between three individual AOC-free vials (i.e., triplicate measurements per sample), incubated in the dark at $30{ }^{\circ} \mathrm{C}$, and lastly measured for intact cell count (ICC) or ATP over a growth period of 20 days. BGP was expressed as the maximum intact cell count or ATP concentration obtained during the incubation period. BGP based on intact cell count by FCM is denoted as BGPICC whereas BGP based on ATP is denoted as BGP ATP. Moreover, a broth of trace elements was used for growth limitation experiments, where two stock solutions were prepared ( $\mathrm{pH} \sim 7$ ): stock solution A containing $5 \mathrm{mg} / \mathrm{L} \mathrm{CoCl}_{2} .6 \mathrm{H}_{2} \mathrm{O}$ and 10 $\mathrm{mg} / \mathrm{L} \mathrm{H}_{3} \mathrm{BO}_{3}$; and stock solution $\mathrm{B}$ containing $500 \mathrm{mg} / \mathrm{L} \mathrm{MnSO}_{4} .7 \mathrm{H}_{2} \mathrm{O}, 10 \mathrm{mg} / \mathrm{L}$ $\mathrm{ZnSO}_{4} .7 \mathrm{H}_{2} \mathrm{O}$, and $300 \mathrm{mg} / \mathrm{L} \mathrm{FeSO}_{4} .7 \mathrm{H}_{2} \mathrm{O}$. The stock solutions were kept in the dark at room temperature. Aliquots of 4 and $3.7 \mathrm{~mL} / \mathrm{L}$ from stock solutions $\mathrm{A}$ and $\mathrm{B}$, respectively, were added in water samples, resulting in final concentrations of $5 \mu \mathrm{g} / \mathrm{L} \mathrm{Co}, 6.5 \mu \mathrm{g} / \mathrm{L} \mathrm{B}, 359 \mu \mathrm{g} / \mathrm{L}$ $\mathrm{Mn}, 8.5 \mu \mathrm{g} / \mathrm{L} \mathrm{Zn}, 215 \mu \mathrm{g} / \mathrm{L} \mathrm{Fe}$, and $345 \mu \mathrm{g} / \mathrm{L} \mathrm{S}$. Moreover, adding phosphate and nitrogen was accompanied with the addition of $29.2 \mu \mathrm{g} / \mathrm{L} \mathrm{K}$, as elaborated in the following sections.

\subsubsection{Intact cell count (ICC)}

ICC was measured using flow cytometry (BD Accuri C $6{ }^{\circledR}$ FCM, BD Biosciences, Belgium) coupled with DNA staining (a mix of $\mathrm{SYBR}^{\circledR}$ Green I and propidium iodide stains) as previously described by Prest et al. (2016a). The detection limit is $10^{3} \mathrm{ICC} / \mathrm{mL}$. Moreover, data obtained by FCM, namely the ratio of high and low nucleic acid bacteria (HNA and LNA) as well as forward and sideward scatter signals (FSC and SSC), were analysed for both water types as described by Wang et al. (2009).

\subsubsection{Adenosine triphosphate (ATP)}

Intracellular ATP from microorganisms was measured according to the filtration-based method described by Abushaban et al. (2019) using a Water-Glo testing kit (lysis reagent and detection reagent) and a GloMax ${ }^{\circledR}-20 / 20$ Luminometer (Promega Corp., USA). The detection limit is $0.1 \mathrm{ng} \mathrm{ATP/L}$. An ATP calibration line was prepared for each water type (Tap-water and RO-water) to convert the measured emitted light (relative light units, RLU) into intracellular ATP concentration, as shown in Figure 5.1. 
Comparing the bacterial growth potential of ultra-low nutrient drinking water assessed by growth tests based on flow cytometric intact cell count versus adenosine triphosphate
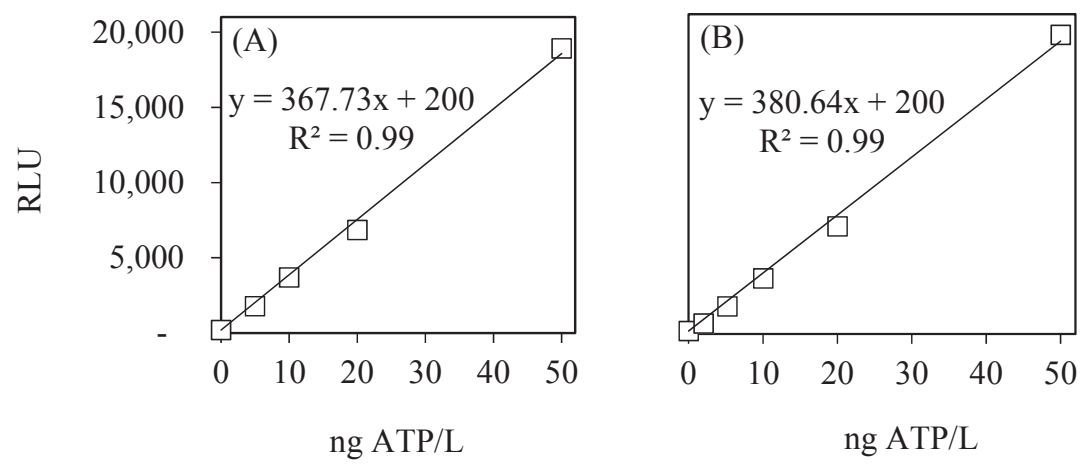

Figure 5.1. The ATP calibration line prepared for conventionally treated water $(C T W, A)$ and laboratory-remineralised RO permeate (lab-Remin, B) to convert the measured emitted light (RLU) into intracellular ATP concentration.

\subsubsection{Experimental approach}

Experiments were conducted with two types of water: conventionally treated water (Tapwater) and ultra-low nutrient drinking water prepared by remineralising RO permeate (ROwater). Samples of Tap-water and RO-water were pasteurised and inoculated with bacteria originating from Tap-water as described in the previous section. Thereafter, six different nutrient combinations (carbon, phosphate, and nitrogen) were added to these samples prior to BGP measurement, as shown in Figure 5.2, where:

- zone A represents the actual BGP of Tap-water or RO-water without the addition of nutrients (results presented in Figure 5.3);

- zone B represents BGP measurement with the addition of C:N:P up to a ratio of 100:10:1 according to bacterial elemental composition (Hammes and Egli, 2005) (results presented in Figure 5.6); and

- zone $\mathrm{C}$ represents BGP measurement with the addition of extra carbon considering a C:N:P ratio of 100-300:10:1 (results presented in Figure 5.10).

Nutrients were added from the following stock solutions: $0.219 \mathrm{~g} / \mathrm{L} \mathrm{KH}_{2} \mathrm{PO}_{4}$ (for phosphate addition), $3.607 \mathrm{~g} / \mathrm{L} \mathrm{KNO}_{3}$ (for nitrogen addition), and 1,000 $\pm 50 \mathrm{mg} / \mathrm{L}$ Ac-C (for carbonacetate addition). Bacterial yield $(\mathrm{Y})$ is calculated from the slope of the linear increase in ICC or ATP with the standard carbon addition. 
Comparing the bacterial growth potential of ultra-low nutrient drinking water assessed by growth tests based on flow cytometric intact cell count versus adenosine triphosphate

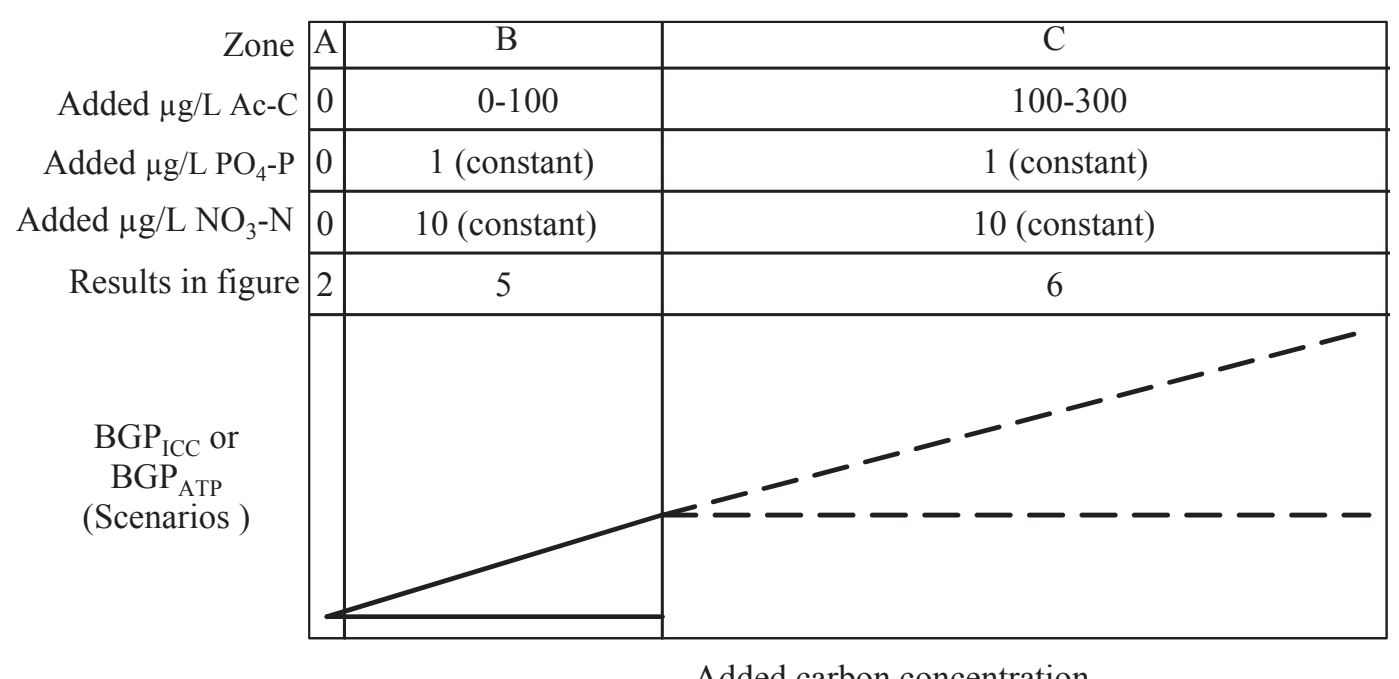

Added carbon concentration

Figure 5.2. The experimental approach and test zones (A, B, and C) showing the possible scenarios for the BGP of conventionally treated water (Tap-water) and remineralised RO permeate (RO-water) with the addition of nutrients. Zone A: BGP without the addition of nutrients (results given in Figure 5.3); zone B: BGP with the addition of $C: N: P$ up to a ratio of 100:10:1 (results given in Figure 5.6); and zone C: BGP with the addition of extra carbon considering a $C: N: P$ ratio of 100-300:10:1 (results given in Figure 5.10).

Based on the BGP results, the following calculations were made:

$$
\begin{aligned}
& \text { Ratio BGPICC }=(\text { BGPICC of Tap-water) } / \text { (BGPICC of RO-water }) \\
& \text { Ratio } \mathrm{BGP}_{\text {ATP }}=\left(\mathrm{BGP}_{\text {ATP }} \text { of Tap-water }\right) /\left(\mathrm{BGP}_{\text {ATP }} \text { of RO-water }\right) \\
& \text { Ratio } \text { YICC }_{\text {I }}\left(\mathrm{Y}_{\text {ICC }} \text { of Tap-water }\right) /\left(\mathrm{Y}_{\text {ICC }} \text { of RO-water }\right) \\
& \text { Ratio } \mathrm{Y}_{\mathrm{ATP}}=\left(\mathrm{Y}_{\mathrm{ATP}} \text { of Tap-water }\right) /\left(\mathrm{Y}_{\text {ATP }} \text { of RO-water }\right)
\end{aligned}
$$

In addition to the previous calculations, the growth-limiting nutrient was determined using BGPICC and BGPATP as described in Sousi et al. (2020a).

\subsubsection{Statistical analysis}

The significance level of observed differences between samples was examined using Student's $t$-test and one-way analysis of variance (ANOVA) test after affirming the data normality (Q-Q plots, Chi-squared tests, and Kolmogorov-Smirnov tests). In addition, a simple linear correlation between two quantitative variables was applied. Calculations for statistical analysis were conducted using the Microsoft Excel software (version 2013) considering 95\% confidence interval (alpha of 0.05 ). 
Comparing the bacterial growth potential of ultra-low nutrient drinking water assessed by growth tests based on flow cytometric intact cell count versus adenosine triphosphate

\subsection{Results}

\subsubsection{The ratio of BGPICC and BGPATP between Tap-water and RO-water}

The BGPICC of Tap-water and RO-water without the addition of any nutrient were $436 \pm 20$ $\times 10^{3}$ and $58 \pm 3 \times 10^{3} \mathrm{ICC} / \mathrm{mL}$, respectively, as shown in Figure 5.3A, which resulted in a BGPICC ratio of about 7.5 between the two water types. The corresponding BGP ATP under the same conditions were $20.10 \pm 1.40$ and $4.32 \pm 1.10 \mathrm{ng} \mathrm{ATP/L}$, respectively, as shown in Figure 5.3B, the ratio of which was about 4.5. The results of BGPICC and BGPATP clearly demonstrated that the ratio of BGP between Tap-water and RO-water was significantly influenced by the parameter used (i.e., ICC by FCM vs. ATP). Moreover, based on the aforementioned observations, the ATP per cell for Tap-water $\left(4.6 \times 10^{-17} \mathrm{~g} \mathrm{ATP} /\right.$ cell $)$ was considerably lower than that of RO-water $\left(7.4 \times 10^{-17} \mathrm{~g} \mathrm{ATP} /\right.$ cell $)$.

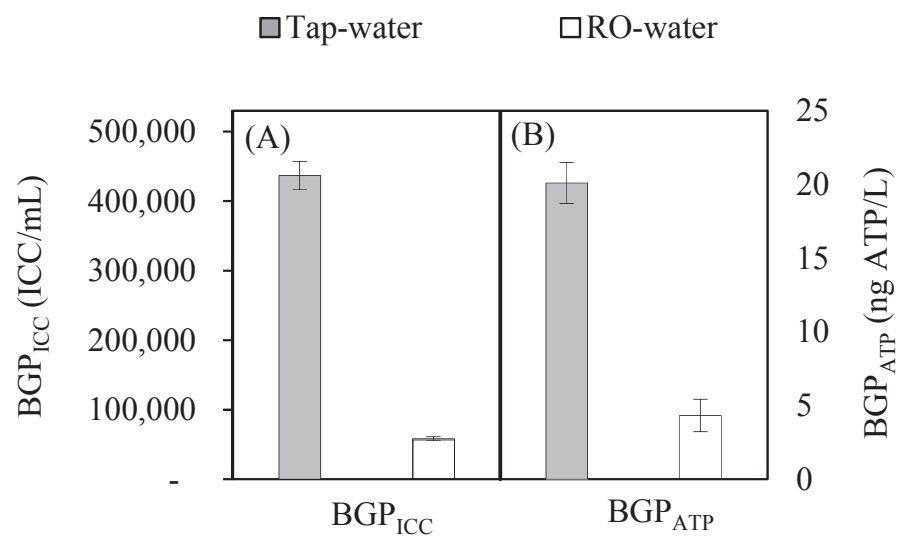

Figure 5.3. The reduction in $\mathrm{BGP}_{\mathrm{ICC}}(7.5$ times, $\mathrm{A})$ and $\mathrm{BGP}_{\mathrm{ATP}}(4.5$ times, $\mathrm{B})$ obtained by applying RO treatment (RO-water) as compared with conventional water treatment (Tapwater) (zone $A$ in Figure 5.2).

\subsubsection{The intact cell-yield ( $\mathrm{Y}_{\text {ICC }}$ ) and ATP-yield ( $\left.\mathrm{Y}_{\mathrm{ATP}}\right)$ based on the growth curves of Tap-water vs. RO-water}

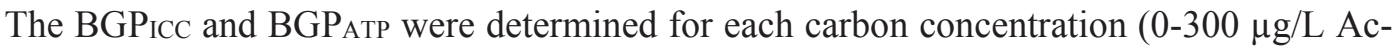
C) based on the 14 days' growth curves of ICC (Figure 5.4) and ATP (Figure 5.5). The ATP concentration after pasteurisation on the first test day was $<0.1 \mathrm{ng} / \mathrm{L}$ in both water types. However, the corresponding ICC in RO-water was $<10^{3} \mathrm{ICC} / \mathrm{mL}$, whereas Tap-water contained around $100 \times 10^{3} \mathrm{ICC} / \mathrm{mL}$ of pasteurisation-resistant cells, which could not grow during the growth test period (Sousi et al., 2020b). 
Comparing the bacterial growth potential of ultra-low nutrient drinking water assessed by growth tests based on flow cytometric intact cell count versus adenosine triphosphate

For RO-water, it was observed that the growth peak was quicker obtained with ATP than ICC ( 3 days vs. 4-7 days) for all carbon concentrations. Similar phenomenon was observed for Tap-water when $>5 \mu \mathrm{g} / \mathrm{L}$ Ac-C was added, where a second ATP peak was also observed after 7-10 days. However, for Tap-water with low carbon concentrations (0-5 $\mu \mathrm{g} / \mathrm{L} \mathrm{Ac-C})$, both ATP and ICC peaks were obtained after 7-10 days. In addition, Figures 5.4 and 5.5 clearly demonstrate that ATP concentration significantly dropped after reaching the peak, especially with the addition of high carbon concentrations, irrespective of the type of water. On the contrary, ICC was maintained around the peak value until day 14 when considering low carbon concentrations $(0-100 \mu \mathrm{g} / \mathrm{L}$ Ac-C), whereas a drop in ICC was observed after day 4 to 6 at carbon concentrations of 200 and $300 \mu \mathrm{g} / \mathrm{L} \mathrm{Ac-C}$.
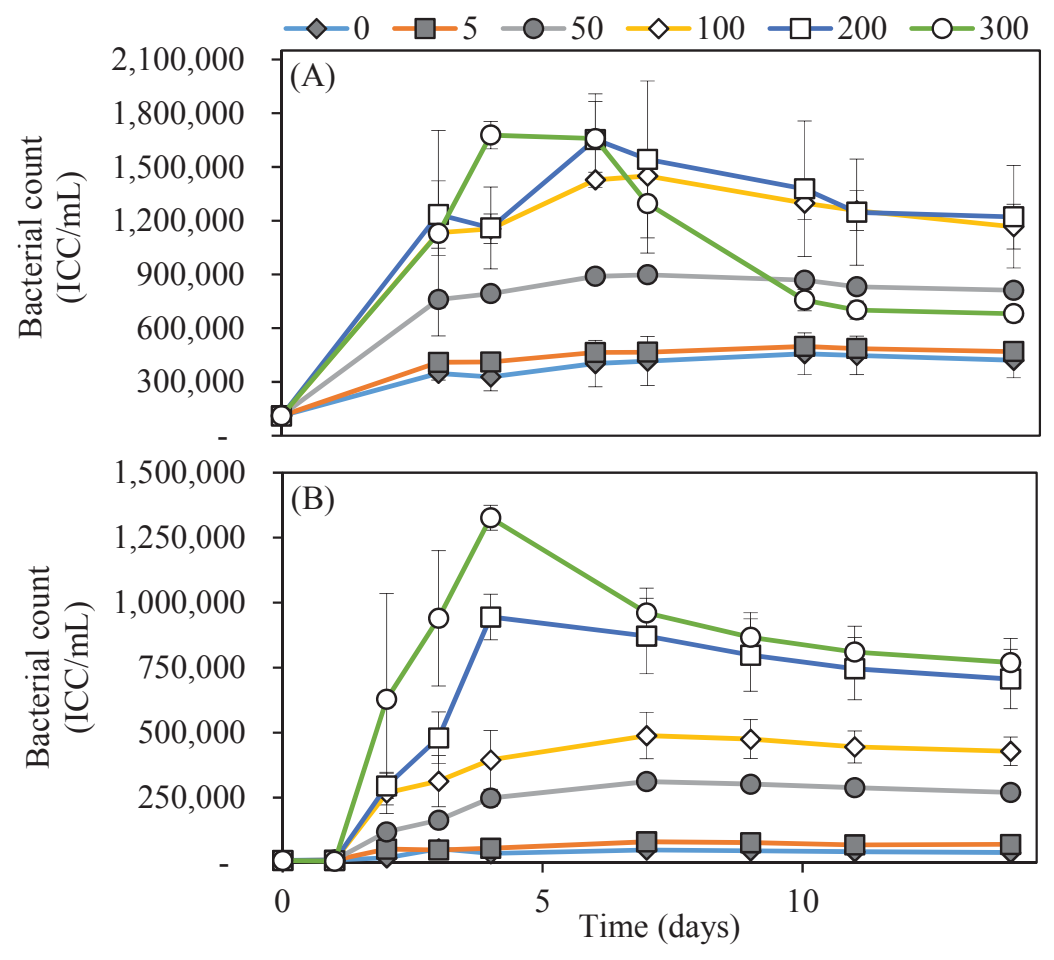

Figure 5.4. The growth $\left(30^{\circ} \mathrm{C} ; 14\right.$ days) of bacteria originating from conventionally treated water in their own water (A) and RO-treated water (B) obtained by FCM after inoculating with $\sim 10^{4} \mathrm{ICC} / \mathrm{mL}$. Each curve represents the growth on a certain carbon concentration (0$300 \mu \mathrm{g} / \mathrm{L} \mathrm{Ac}-\mathrm{C}$ ). Error bars represent the standard deviation of triplicate samples. 
Comparing the bacterial growth potential of ultra-low nutrient drinking water assessed by growth tests based on flow cytometric intact cell count versus adenosine triphosphate
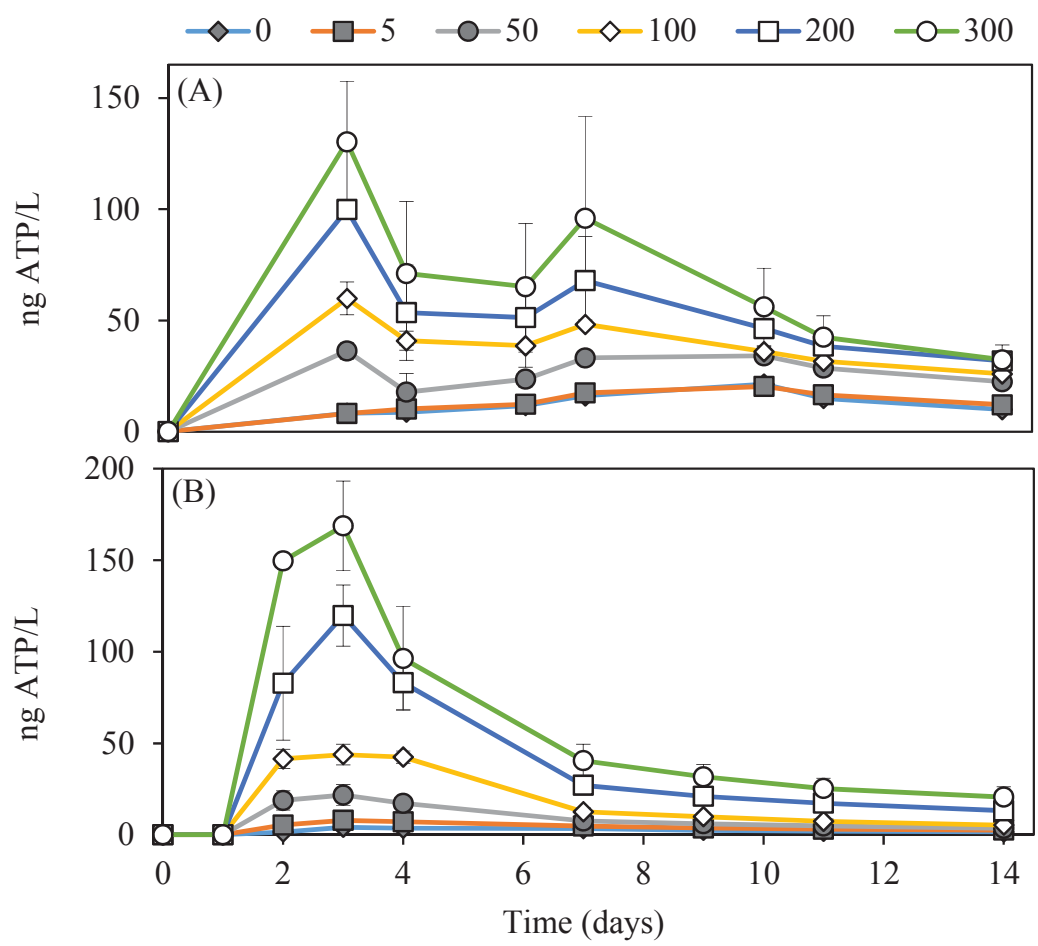

Figure 5.5. The growth $\left(30^{\circ} \mathrm{C} ; 14\right.$ days) of bacteria originating from conventionally treated water in their own water (A) and RO-treated water (B) obtained by ATP. Each curve represents the growth on a certain carbon concentration $(0-300 \mu \mathrm{g} / \mathrm{L} \mathrm{Ac-C})$. Error bars represent the standard deviation of triplicate samples.

The analysis of FCM data showed that $80 \%$ of the cells growing in Tap-water and RO-water were HNA bacteria. However, both FSC and SSC signals were higher for RO-water than Tap-water at all carbon concentrations, indicating larger bacterial cells in RO-water, i.e., an average of 2,200 vs. 880 for FSC and 2,100 vs. 1,200 for SSC, respectively (Table 5.3).

Table 5.3. The ratio of high nucleic acid (HNA) bacteria and maximum forward scatter (FSC) and sideward scatter (SSC) of HNA bacteria during the growth in Tap-water and RO-water.

\begin{tabular}{lllllll}
\hline & \multicolumn{3}{l}{ Tap-water } & \multicolumn{3}{l}{ RO-water } \\
\hline C $(\boldsymbol{\mu g} / \mathbf{L}$ Ac-C) & HNA\% & FSC & SSC & HNA\% & FSC & SSC \\
\hline $\mathbf{0}$ & $65 \%$ & 903 & 1,218 & $81 \%$ & 1,091 & 2,351 \\
$\mathbf{5}$ & $61 \%$ & 889 & 1,186 & $83 \%$ & 1,753 & 2,172 \\
$\mathbf{5 0}$ & $80 \%$ & 749 & 1,093 & $84 \%$ & 2,137 & 1,812 \\
$\mathbf{1 0 0}$ & $88 \%$ & 769 & 1,093 & $85 \%$ & 2,643 & 2,629 \\
$\mathbf{2 0 0}$ & $89 \%$ & 911 & 1,279 & $86 \%$ & 2,483 & 1,767 \\
$\mathbf{3 0 0}$ & $91 \%$ & 1,081 & 1,423 & $86 \%$ & 3,231 & 1,981 \\
\hline
\end{tabular}


Comparing the bacterial growth potential of ultra-low nutrient drinking water assessed by growth tests based on flow cytometric intact cell count versus adenosine triphosphate

YICC $_{\text {ICnd }} \mathrm{Y}_{\mathrm{ATP}}$ for both water types were determined based on the slope of the linear increase in BGPICC and BGPATP with the standard addition of carbon up to $100 \mu \mathrm{g} / \mathrm{L}$ Ac-C (Figure 5.6), where carbon was not limiting the growth due to the addition of phosphate $(1 \mu \mathrm{g} / \mathrm{L}$ $\left.\mathrm{PO}_{4}-\mathrm{P}\right)$ and nitrogen $\left(10 \mu \mathrm{g} / \mathrm{L} \mathrm{NO}_{3}-\mathrm{N}\right)$ according to the ratio of $\mathrm{C}: \mathrm{N}: \mathrm{P}=100: 10: 1$. The $\mathrm{Y}_{\text {ICC }}$ for RO-water was $4.6 \pm 0.1 \times 10^{6}$ cells $/ \mu \mathrm{g}-\mathrm{C}$, which was not influenced by the addition of trace elements (K, $\mathrm{Co}, \mathrm{H}_{3} \mathrm{BO}_{3}, \mathrm{Mn}, \mathrm{Zn}, \mathrm{Fe}$, and $\mathrm{S}$, Figure 5.7), indicating that these trace elements were not the limiting factor for bacterial growth even in the ultrapure RO-treated water.

For Tap-water, the YICC was $9.8 \pm 0.6 \times 10^{6}$ cells $/ \mu \mathrm{g}$-C, which was $\sim 2$ times higher than that in the RO-water (Figure 5.6A). Conversely, the Y ATP for both water types was similar (ratio of $\sim 1$ ), which was $0.39 \pm 0.12$ and $0.42 \pm 0.06 \mathrm{ng} \mathrm{ATP} / \mu \mathrm{g}-\mathrm{C}$ for Tap-water and RO-water, respectively (Figure 5.6B).
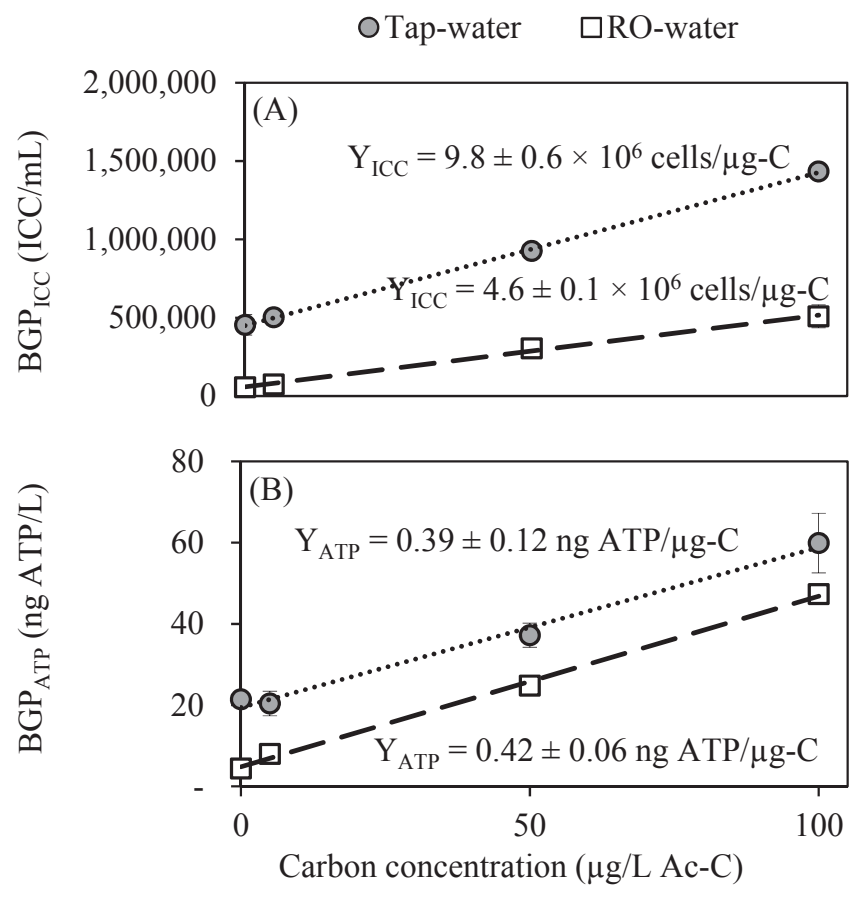

Figure 5.6. The intact cell-yield ( $Y_{\text {ICC }}$, cells/ $\mu$ g-C) and ATP-yield ( $Y_{\text {ATP }}, n g$ ATP/ $/ \mu$-C) obtained for conventionally treated water (Tap-water) and laboratory-remineralised RO permeate (RO-water) at a carbon range of 0 (no carbon added) to $100 \mu \mathrm{g} / \mathrm{L}$ Ac-C. Phosphate $(1 \mu \mathrm{g} / \mathrm{L}$ $\left.\mathrm{PO}_{4}-\mathrm{P}\right)$ and nitrogen $\left(10 \mu \mathrm{g} / \mathrm{L} \mathrm{NO}_{3}-\mathrm{N}\right)$ were added to all samples (zone $\mathrm{B}$ in Figure 5.2). 
Comparing the bacterial growth potential of ultra-low nutrient drinking water assessed by growth tests based on flow cytometric intact cell count versus adenosine triphosphate

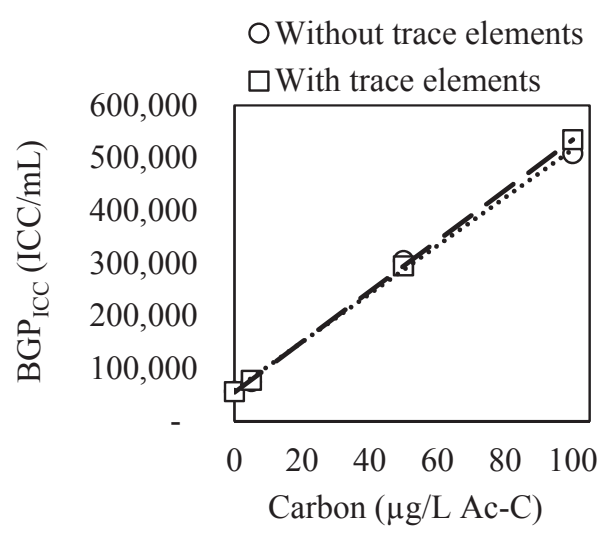

Figure 5.7. The BGP ICC obtained for laboratory-remineralised $\mathrm{RO}$ permeate (RO-water) at different carbon concentrations ranging from 0 (no carbon added) to $100 \mu \mathrm{g} / \mathrm{L} \mathrm{Ac-C}$, with and without the addition of trace elements (K, $\mathrm{Co}, \mathrm{H}_{3} \mathrm{BO}_{3}, \mathrm{Ca}, \mathrm{Mn}, \mathrm{Zn}, \mathrm{Fe}$, and S). Phosphate (1 $\left.\mu \mathrm{g} / \mathrm{L} \mathrm{PO} \mathrm{PO}_{4}-\mathrm{P}\right)$ and nitrogen $\left(10 \mu \mathrm{g} / \mathrm{L} \mathrm{NO}_{3}-\mathrm{N}\right)$ were added to all samples. Cell-yield is calculated based on the slope of each line.

Based on the ICC and ATP results, the maximum ATP per cell was calculated for each carbon concentration (Figure 5.8). The ATP per cell values for RO-water were consistently 2-4 times higher than these for Tap-water, where the spike of carbon in RO-water resulted in an increase of $50 \%$ in ATP per cell, even at $5 \mu \mathrm{g} / \mathrm{L}$ Ac-C. While for Tap-water, the ATP per cell values were stable around the same level for the whole carbon range of 0-300 $\mu \mathrm{g} / \mathrm{L}$ Ac-C.

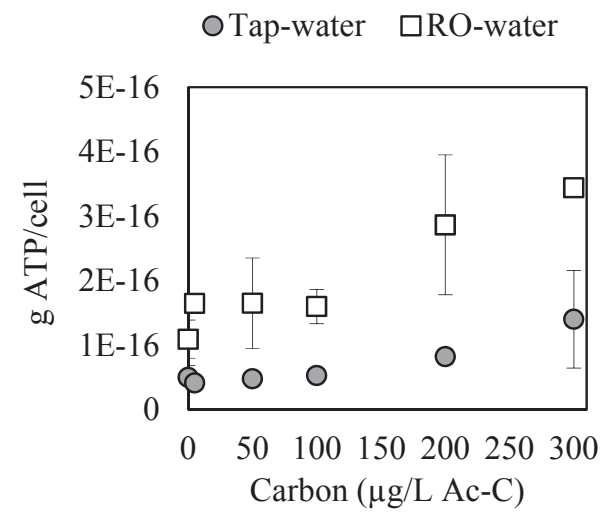

Figure 5.8. ATP per cell for conventionally treated water (Tap-water) and laboratoryremineralised $\mathrm{RO}$ permeate (RO-water) at different carbon concentrations ranging from 0 to $300 \mu \mathrm{g} / \mathrm{L}$ Ac-C. Phosphate $\left(1 \mu \mathrm{g} / \mathrm{L} \mathrm{PO}_{4}-\mathrm{P}\right)$ and nitrogen $\left(10 \mu \mathrm{g} / \mathrm{L} \mathrm{NO}_{3}-\mathrm{N}\right)$ were added to all samples. 
Comparing the bacterial growth potential of ultra-low nutrient drinking water assessed by growth tests based on flow cytometric intact cell count versus adenosine triphosphate

\subsubsection{Growth-limiting nutrient identified by BGPIcc and BGP ${ }_{\text {ATP }}$ for Tap-water vs. RO-water}

As shown in Figure 5.9, both BGPICC and BGP ATP of Tap-water without the addition of nutrients were comparable to these of Tap-water with $1 \mu \mathrm{g} / \mathrm{L} \mathrm{PO}_{4}-\mathrm{P}$ and $10 \mu \mathrm{g} / \mathrm{L} \mathrm{NO} 3-\mathrm{N}$ added. Similarly, no significant difference was observed between the BGPICC and BGPATP of RO-water with or without the addition of carbon. Therefore, both BGPICC and BGPATP revealed that carbon was the growth-limiting nutrient in Tap-water as well as RO-water.
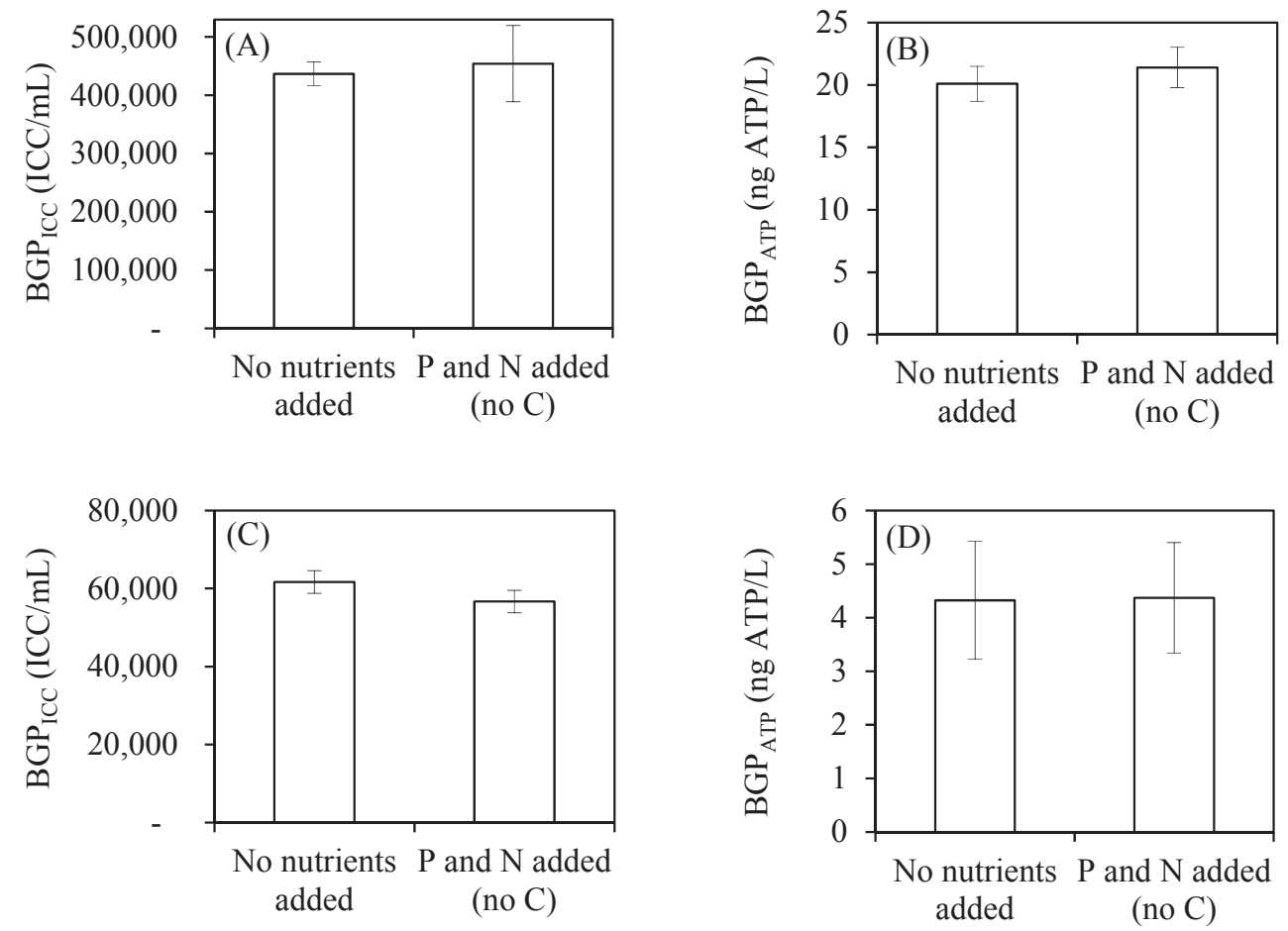

Figure 5.9. The BGP $\mathrm{ICC}_{\mathrm{C}}$ and $\mathrm{BGP}_{\mathrm{ATP}}$ obtained for conventionally treated water (Tap-water, A and $B$ ) and laboratory-remineralised RO permeate (RO-water, C and D) without the addition of nutrients or with the addition of phosphate and nitrogen (no carbon added).

When carbon was added, clear differences were observed (Figure 5.10). For Tap-water, a linear increase in BGPICC was observed until the addition of $100 \mu \mathrm{g} / \mathrm{L} \mathrm{Ac-C}$ when the ratio of added C:N:P was 100:10:1 (Figure 5.10A, left). Afterwards, a plateaued curve was established, where the difference in BGPICC was insignificant for 100, 200, or $300 \mu \mathrm{g} / \mathrm{L} \mathrm{Ac}$ $\mathrm{C}$ addition $(P<0.05)$ (Figure 5.10A, right). The BGPICC of Tap-water increased from $454 \pm$ $65 \times 10^{3} \mathrm{ICC} / \mathrm{mL}$ with no carbon addition to the level of $1,500 \times 10^{3} \mathrm{ICC} / \mathrm{mL}$ with the addition of 100,200 , or $300 \mu \mathrm{g} / \mathrm{L} \mathrm{Ac-C}$, indicating that there might be other elements (e.g., 
Comparing the bacterial growth potential of ultra-low nutrient drinking water assessed by growth tests based on flow cytometric intact cell count versus adenosine triphosphate

phosphate) limiting cell multiplication. On the contrary, such a trend was not observed for

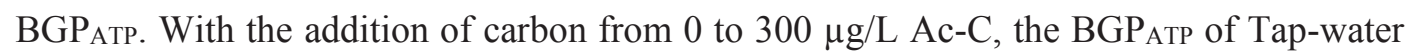
showed a linear increase from $21.41 \pm 1.62 \mathrm{ng}$ ATP/L to $130.32 \pm 27.14 \mathrm{ng}$ ATP/L (Figure

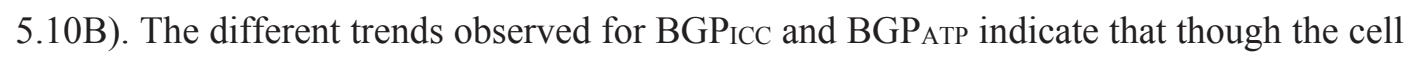
number reached a stable level due to the limitation on cell multiplication, the cellular activity kept increasing. To obtain a holistic view, the actual $\mathrm{C}: \mathrm{N}: \mathrm{P}$ ratio was calculated by including the internally available nutrients in Tap-water and RO-water (Table 5.4). The original AOC in Tap-water was $\sim 45 \mu \mathrm{g} / \mathrm{L}$ Ac-C ( $\sim 10$ times higher than AOC P17 and NOX) considering the YICC obtained in Figure 5.6A, meaning that the actual C:N:P ratio was 145:2910: 2 with the addition of $100 \mu \mathrm{g} / \mathrm{L} \mathrm{Ac-C}$. On the other hand, for RO-water, both BGPICC and BGPATP increased linearly along the whole range of carbon addition from 0 to $300 \mu \mathrm{g} / \mathrm{L}$ Ac-C (Figure 5.10A and $\mathrm{B}$ ), indicating that there was no growth or activity limitation observed for ROwater. Remarkably, the BGPICC for RO-water was approaching but did not reach the cell number limitation observed for Tap-water $\left(1,327 \pm 48 \times 10^{3}\right.$ vs. $\left.1,500 \times 10^{3} \mathrm{ICC} / \mathrm{mL}\right)$.
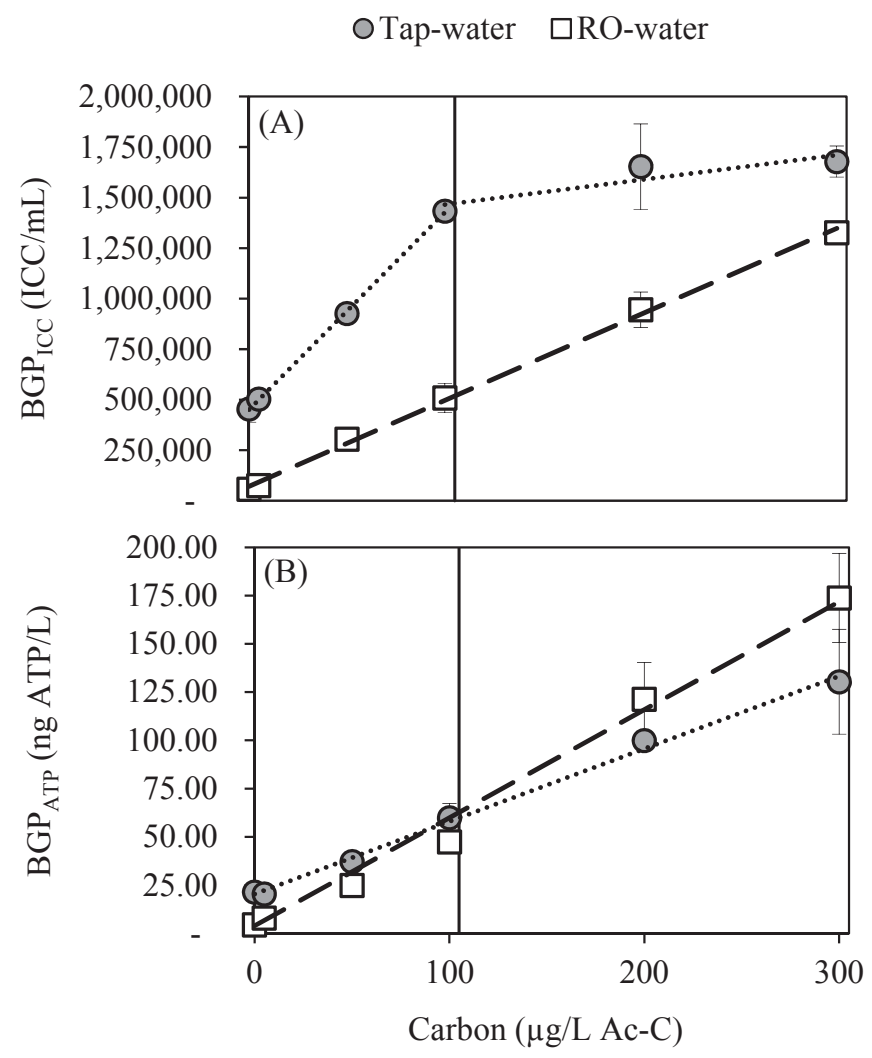

Figure 5.10. The differences observed in intact cell-yield ( $\left.\mathbf{Y}_{\text {ICC }}, A\right)$ and ATP-yield $\left(Y_{A T P}, B\right)$ between conventionally treated water (Tap-water) and RO-treated water when phosphate was theoretically limiting bacterial growth: 100-300 $\mu \mathrm{g} / \mathrm{L} \mathrm{Ac-C,} 1 \mu \mathrm{g} / \mathrm{L} \mathrm{PO}_{4}-\mathrm{P}$, and $10 \mu \mathrm{g} / \mathrm{L} \mathrm{NO} \mathrm{N}_{3}-\mathrm{N}$ (zone $\mathrm{C}$ in Figure 5.2). 
Comparing the bacterial growth potential of ultra-low nutrient drinking water assessed by growth tests based on flow cytometric intact cell count versus adenosine triphosphate

Table 5.4. The actual C:N:P ratio under different conditions in Tap-water and RO-water. Internal AOC was calculated based on $\mathrm{Y}_{\mathrm{ICC}}$ obtained in Figure 5.6A. The concentrations of $\mathrm{N}$ and $P$ were calculated based on the water quality analysis in Table 5.2.

\begin{tabular}{|c|c|c|c|c|}
\hline & \multicolumn{4}{|c|}{ C:N:P ratio } \\
\hline & Carbon added $(\mu \mathrm{g} / \mathrm{L}$ Ac-C) & $\mu \mathrm{g} / \mathrm{L}$ Ac-C & $\mu \mathrm{g} / \mathrm{L} \mathrm{NO}_{3}-\mathrm{N}$ & $\mu \mathrm{g} / \mathrm{L} \mathrm{PO}_{4}-\mathrm{P}$ \\
\hline \multirow{7}{*}{ 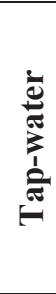 } & no addition (Actual ratio) & 45 & 2900 & $\sim 1$ \\
\hline & 0 & $45+0$ & $2900+10$ & $\sim 1+1$ \\
\hline & 5 & $45+5$ & $2900+10$ & $\sim 1+1$ \\
\hline & 50 & $45+50$ & $2900+10$ & $\sim 1+1$ \\
\hline & 100 & $45+100$ & $2900+10$ & $\sim 1+1$ \\
\hline & 200 & $45+200$ & $2900+10$ & $\sim 1+1$ \\
\hline & 300 & $45+300$ & $2900+10$ & $\sim 1+1$ \\
\hline \multirow{7}{*}{ 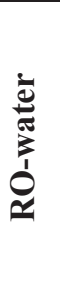 } & no addition (Actual ratio) & 10 & 250 & $\sim 1$ \\
\hline & 0 & $10+0$ & $250+10$ & $\sim 1+1$ \\
\hline & 5 & $10+5$ & $250+10$ & $\sim 1+1$ \\
\hline & 50 & $10+50$ & $250+10$ & $\sim 1+1$ \\
\hline & 100 & $10+100$ & $250+10$ & $\sim 1+1$ \\
\hline & 200 & $10+200$ & $250+10$ & $\sim 1+1$ \\
\hline & 300 & $10+300$ & $250+10$ & $\sim 1+1$ \\
\hline
\end{tabular}

\subsection{Discussion}

Intact cell count (ICC) and ATP measurements were used to evaluate the bacterial growth potential of conventionally treated water (Tap-water) and ultra-low nutrient water prepared by remineralising $\mathrm{RO}$ permeate (RO-water). Combining the results obtained by intact cell count and ATP allowed for integral understanding of the bacterial growth characteristics of each water type. In addition, trace elements, N, P, and different concentrations of acetate carbon were added for performing a matrix of BGP tests, which allowed for the investigation of growth limiting factors and the comparison between ICC and ATP for measuring bacterial growth dynamics.

\subsubsection{Reduction in BGPICc and BGPATP achieved by RO-based treatment}

In the present study, both BGPICC and BGP ATP showed that RO-based treatment (RO-water) resulted in a significantly lower BGP than that of conventional treatment (Tap-water) (Figure 5.3), which is in line with previous findings on RO performance for controlling bacterial growth (Park and Hu, 2010; Thayanukul et al., 2013; Sousi et al., 2020a). This could be explained by the high AOC rejection efficiency of RO membrane (Escobar et al., 2000; Hong et al., 2005). In addition, although the same bacterial consortium was inoculated in both water types, the difference in water matrix might have also contributed to the 
Comparing the bacterial growth potential of ultra-low nutrient drinking water assessed by growth tests based on flow cytometric intact cell count versus adenosine triphosphate

reduction in BGP achieved by RO treatment, such as the difference in inorganic and/or trace elements. For example, the conductivity in RO-water was 3 times lower than that of Tapwater $(20.9 \mathrm{mS} / \mathrm{m}$ vs. $63.2 \mathrm{mS} / \mathrm{m}$, Table S2). The BGP tests performed on RO-water with addition of $\mathrm{Ca}, \mathrm{Mg}, \mathrm{HCO}_{3}{ }^{-}$, and other essential trace elements (i.e. $\mathrm{K}, \mathrm{Co}, \mathrm{Zn}, \mathrm{Fe}, \mathrm{Mn}, \mathrm{S}$, and hydrogen borate) confirmed that none of these elements was the growth limiting factor in the ultra-low nutrient RO permeate. Based on the previous observations, it is hypothesised that bacterial in RO-treated water might be limited not only by organic compounds but also by certain inorganic constituents that were present in Tap-water at extremely low concentrations, which were not included in this study.

However, the results revealed that the magnitude of BGP reduction was dependent on the parameter used, where BGPICC showed a higher reduction ratio (7.5 times) compared with BGP ATP (4.5 times). The different degree of bacterial growth measured by ICC and ATP was previously reported, and attributed to the discrepancy of the two measurements and the possibility of missing the ATP peak because of the rapid increase and collapse in ATP values when readily available carbon such as acetate is added (Farhat et al., 2018). Such discrepancies were observed in the present study, where the measurement of bacterial growth with the addition of acetate carbon revealed that the ATP peak was obtained after 3 days while the ICC reached the peak within 4-7 days (Figures 5.4 and 5.5). Moreover, Farhat et al. (2018) argued that both methods are accurate and reliable, while the definition of growth in terms of cell multiplication or active biomass formation dictates which method evaluates the growth better, and suggested that the combination of BGPICC and BGPATP, together with the parameter ATP per cell offers more insight into growth potential.

Although the same bacteria originating from conventionally treated water were used as an inoculum in the present study, the ATP per cell of RO-water was consistently higher (2-4 times) than that of Tap-water, indicating that there might be different bacteria thrived in the two water types. The higher ATP per cell in RO-water was in line with the FCM data (FSC and SSC signals), which were higher in RO-water compared with Tap-water, affirming the larger cell size in RO-water (Wang et al., 2009; Sousi et al., 2020a). It is well known that the level of ATP production is influenced by environmental conditions (Hespell and Bryant, 1979; Boström and Törnblom, 1990), where ATP production would be affected when cells are subjected to conditions that are different from their original environment, which could explain the higher ATP per cell in RO-water compared with Tap-water. Moreover, the standard carbon addition tests showed that the Tap-water bacterial consortium inoculated in RO-water converted carbon into ATP for bioactivities (e.g., synthesis of reserve materials, mobility (Hammes et al., 2010b; Mempin et al., 2013)) as efficient as in their own water, where a comparable YATP was observed in both water types. However, two ATP peaks were observed in Tap-water, corresponding to the added readily available organic carbon (first peak) and the natural organic compounds present in water (second peak) (van der Kooij et al., 2017). The second peak was not observed in RO-water because of its ultra-low nutrient content, specifically complex organic compounds as measured by LC-OCD (Table 5.2). The 
Comparing the bacterial growth potential of ultra-low nutrient drinking water assessed by growth tests based on flow cytometric intact cell count versus adenosine triphosphate

concentration of ATP quickly dropped after the first peak in both water types, which could be attributed to the rapid response of ATP production to environmental changes i.e., the addition and consumption of acetate in this case. The drop in intracellular ATP concentrations could imply increasing extracellular ATP during growth (Mempin et al., 2013; Ihssen et al., 2021), or an actual decrease in intracellular ATP due to physiological reasons (i.e., less active cells). The quick drop in intracellular ATP was not accompanied with a significant decrease in cell numbers, indicating that cells were maintaining themselves with low levels of energy and bioactivities.

Bacterial growth in term of intact cell count, and thus intact cell-yield, was significantly affected by the change in the surrounding environment (Tap-water vs. RO-water), where the rate of cell synthesis in RO-water was hindered. According to this comparison, it is suggested that bacteria inoculated in an unfavourable environment (RO-water) tend to convert available nutrients into energy source (ATP) for surviving rather than synthesising new cells. Although the same inoculum was used, there might be different bacteria thrived in Tap-water and RO-water, especially considering the significantly different ATP per cell between the two water types. For future research, it is recommended to investigate the dynamics of bacterial communities and identify which members become dominant during bacterial growth in each water type, which will be valuable for understanding bacterial growth from community composition and structure level. This is especially important considering that each water type contained different bacterial communities (Sousi et al., 2020a).

\subsubsection{The role of phosphate in bacterial growth and the maximum intact cell-yield per $\mu \mathrm{g} \mathrm{PO}_{4}-\mathrm{P}$}

In the present study, both BGPATP and BGPICC clearly showed that carbon was the growth limiting nutrient in Tap-water and $\mathrm{RO}$-water. However, different trends of bacterial growth were observed when $>100 \mu \mathrm{g} / \mathrm{L}$ Ac-C was added, which could be attributed to the phosphate limitation established in Tap-water. This is because nitrogen limitation could be clearly excluded as a result of the data presented in Table 5.2, i.e., excess $\mathrm{NO}_{3}-\mathrm{N}$ at 2910 and 260 $\mu \mathrm{g} / \mathrm{L}$ in Tap-water and RO-water, respectively. Additionally, no growth-limitation effect was observed for a wide range of trace elements $\left(\mathrm{K}, \mathrm{Ca}, \mathrm{Mg}, \mathrm{Mn}, \mathrm{Co}, \mathrm{Zn}, \mathrm{Fe}, \mathrm{H}_{3} \mathrm{BO}_{3}\right.$, and $\mathrm{S}$, Figure 5.7), where even in RO-water, there were sufficient trace elements for cell multiplication until the addition of $300 \mu \mathrm{g} / \mathrm{L}$ Ac-C (Figure 5.10A). Therefore, trace elements limitation was excluded. As such, the actual $\mathrm{C}: \mathrm{P}$ ratio when changing from carbon-limited (Figure 5.2, zone B) to carbon-excess (Figure 5.2, zone C) conditions in Tap-water was 145:2, which is between the Redfield ratio of 100:1 (Hammes and Egli, 2005) and the 50:3 ratio for exponentially growing cells under carbon-limited conditions (Egli, 2009). This complies with the consensus of variable microbial cell composition, which is highly dependent on the cultivation conditions (Herbert, 1961). 
Comparing the bacterial growth potential of ultra-low nutrient drinking water assessed by growth tests based on flow cytometric intact cell count versus adenosine triphosphate

The difference regarding the BGPICC and BGPATP trends of Tap-water with phosphate limitation suggested that phosphate is an essential element necessary for biomass synthesis (Jansson, 1988; Miettinen et al., 1997), but phosphate limitation did not influence the formation of bacterial ATP, because carbon was the main nutrient needed by bacteria to produce ATP required for bio-activities regardless whether new biomass was synthesised or not (Giorgio and Cole, 1998). In other words, this finding indicates that BGP $\mathrm{ATP}_{\text {cannot be }}$ used to detect phosphate limitation in water or to measure growth potential in term of cell synthesis when phosphate is the growth limiting nutrient.

Interestingly, the maximum number of cells obtained in Tap-water at $100 \mu \mathrm{g} / \mathrm{L} \mathrm{Ac-C}$ addition and in RO-water at $300 \mu \mathrm{g} / \mathrm{L}$ Ac-C addition was in the same range $\left(1.3-1.5 \times 10^{6}\right.$ $\mathrm{ICC} / \mathrm{mL}$ ). Therefore, it is reasonable to hypothesise that this is the maximum intact cell count which could be synthesised out of the total available phosphate (i.e., phosphate already present in water as well as the added $1 \mu \mathrm{g} / \mathrm{L} \mathrm{PO}_{4}-\mathrm{P}$ ). Assuming that the already present phosphate in water was around the method detection limit of $1 \mu \mathrm{g} / \mathrm{L}$ PO $4-\mathrm{P}$ (reported values were $0.8-0.9 \mu \mathrm{g} / \mathrm{L} \mathrm{PO}_{4}-\mathrm{P}$ for both water types), intact cell-yield growing on phosphate could be estimated in the range of $0.70 \pm 0.05 \times 10^{9}$ cells $/ \mu \mathrm{g} \mathrm{PO}_{4}-\mathrm{P}$, indicating that significant bacterial growth could be promoted at extremely low phosphate concentrations (Miettinen et al., 1997).

To the best of our knowledge, this is the very first study discussing the potential intact cellyield quantified by FCM on phosphate in drinking water, where there was no data available for comparison. The reported yield based on the standard plate count method was about 3.73 $\times 10^{5} \mathrm{CFU} / \mu \mathrm{g} \mathrm{PO}_{4}-\mathrm{P}$ (Lehtola et al., 1999), which is much lower than that obtained based on FCM. This difference might be caused by the fact that only Pseudomonas fluorescens P17 was used and less than $1 \%$ of bacteria in water could be plate cultivated (Hammes and Egli, 2005; van Nevel et al., 2017). It is worthwhile to mention that a different cell-yield based on phosphate can be obtained for other types of water, which was observed in this study for cell-yield based on carbon (i.e., different cell-yield between Tap-water and RO-treated water).

\subsubsection{Practical insights}

BGP test: BGP ICC $_{\text {and }}$ BGP $_{\text {ATP }}$ are increasingly applied for the assessment of biological stability of drinking water. In general, it is agreed that both methods are rapid, accurate, and

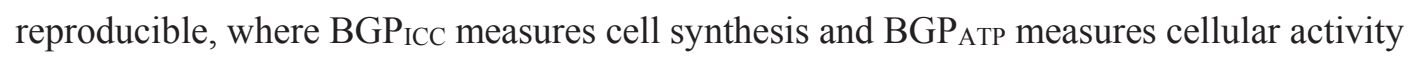
(Vital et al., 2012; Prest et al., 2016a; van der Kooij et al., 2017; Farhat et al., 2018; Sousi et al., 2020a). As reported in this study and elsewhere, the combination of BGPICC and BGP $_{\text {ATP, }}$ in addition to the traditional methods for cell measurement such the determination of cell density and bio-volume, can provide more insight into the bacterial growth, e.g., indepth understanding of cell growth stages and the role of growth limiting nutrients. In

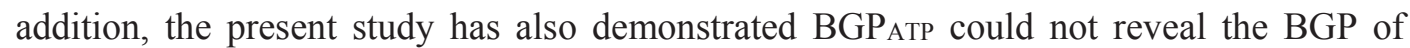
phosphate-limited samples. Therefore, for the choice of BGP method, BGPICC would be 
Comparing the bacterial growth potential of ultra-low nutrient drinking water assessed by growth tests based on flow cytometric intact cell count versus adenosine triphosphate

suitable for all cases, while BGP ATP should be applied only on the carbon-limitation cases. Since most of drinking water is carbon-limited (van der Kooij et al., 1982; Huck, 1990; Schurer et al., 2019; Sousi et al., 2020a), both methods are suitable to be used for bacterial growth potential assessment.

Microbially available phosphate (MAP). As discussed in this study and elsewhere, it is clear that even a very low concentration of phosphate $\left(<1 \mu \mathrm{g} / \mathrm{L} \mathrm{PO}_{4}-\mathrm{P}\right)$ can promote extensive microbial growth (e.g. $>10^{6} \mathrm{ICC} / \mathrm{mL}$ ) (Lehtola et al., 1999; Nescerecka et al., 2018). However, the traditional method for phosphate measurement with the current detection limit of $1 \mu \mathrm{g} / \mathrm{L} \mathrm{PO}_{4}-\mathrm{P}$ can hardly be helpful for bacterial growth evaluation. Using Pseudomonas fluorescens P17 and plate count, Lehtola et al. (1999) was able to develop a sensitive bioassay for determining MAP in water, with a detection limit of $0.08 \mu \mathrm{g} / \mathrm{L} \mathrm{PO}_{4}$ $\mathrm{P}$. The present study demonstrated that by using natural bacterial consortium as an inoculum and applying FCM for intact cell quantification, the MAP bioassay could be significantly improved regarding the representativity and sensitivity (i.e., lower limit of detection). Such a bioassay will be especially valuable for the ultra-low nutrient drinking water, where phosphate concentration is below the current detection limit, but the bacterial growth in water might be phosphate-limited. Another advantage of such a bioassay is that it can be used to measure all types of phosphate that are of importance for bacterial growth in drinking water. 
Comparing the bacterial growth potential of ultra-low nutrient drinking water assessed by growth tests based on flow cytometric intact cell count versus adenosine triphosphate

\subsection{Conclusions}

The assessment of bacterial growth potential (BGP) using both flow cytometric intact cell count (ICC) and adenosine triphosphate (ATP) is especially useful as additional complementary information can be obtained from the combined tests (BGPICC and BGPATP). Comparing conventionally treated drinking water (Tap-water) and ultra-low nutrient water prepared by remineralising $\mathrm{RO}$ permeate (RO-water) using both methods revealed that:

- Although the same bacterial inoculum (originating from Tap-water) was used, the BGPICc ratio between Tap-water/RO-water was about 7.5, whereas the BGPATP ratio was about 4.5 .

- Regarding the yield of bacteria growing on acetate, a comparable ATP-yield was obtained for Tap-water and RO-water $(0.39 \pm 0.12$ vs. $0.42 \pm 0.06 \mathrm{ng} \mathrm{ATP} / \mu \mathrm{g}-\mathrm{C}$, respectively), whereas the intact cell-yield was significantly different $(9.8 \pm 0.6 \times$ $10^{6}$ vs. $4.6 \pm 0.8 \times 10^{6}$ cells $\left./ \mu \mathrm{g}-\mathrm{C}\right)$.

- A consistently higher ATP per cell was observed for RO-water compared with Tapwater, which could be attributed to the fact that the inoculum used was adapted to a significantly higher salinity and a broader range of trace elements than these present in remineralised RO permeate. This indicates that bacterial growth in ultra-low nutrient water could be limited not only by organic compounds, but also inorganic constituents.

- Carbon was identified as the growth-limiting nutrient in the two types of water studied by both BGPICC and BGPATP. With the addition of extra carbon, phosphate

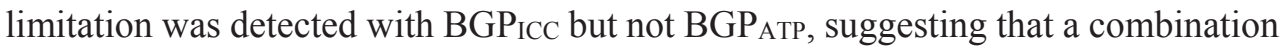
of carbon and phosphate is essential for the synthesis of new cells, whereas carbon is probably used as an energy source for other bacterial activities measured by ATP when phosphate is limited.

- The intact cell-yield growing on phosphate was estimated at $0.70 \pm 0.05 \times 10^{9}$ cells $/ \mu \mathrm{g} \mathrm{PO}_{4}-\mathrm{P}$, indicating that significant bacterial growth could be promoted when extremely low concentrations of phosphate are available. 

CONCLUSIONS AND FUTURE INSIGHTS 
This dissertation presented a detailed investigation of the development and application of current biological stability assessment methods for ultra-low nutrient drinking water produced by reverse osmosis (RO) and remineralisation, taking into consideration the high sensitivity of such water to external contamination during measurement. The main methodology followed in this dissertation to assess biological stability was measuring the bacterial growth potential (BGP) of water using flow cytometry (FCM), which was combined with other methods, including measuring BGP by adenosine triphosphate (ATP) and describing bacterial community composition by $16 \mathrm{~S}$ rRNA gene sequencing, to obtain a holistic perspective of biological stability of this type of drinking water.

To achieve the aim of this research, a pilot-scale treatment scheme comprising anaerobic RO filtration, ion exchange, remineralisation by calcite contactors, and lastly tower aeration has been installed in a drinking water treatment plant in the Netherlands, where the existing full-scale treatment scheme comprises conventional treatment technologies set-up in the following order: (dry) sand filtration, tower aeration, pellet softening, carry-over submerged rapid sand filtration, granular activated carbon filtration, and lastly UV disinfection. Both conventional and RO-based treatment schemes purified anaerobic groundwater, and the product water of each treatment line was collected and assessed for biological stability. The following sections summarise the general conclusions and future perspectives that can be drawn from this dissertation.

\subsection{General findings}

The findings of this dissertation can be divided into three main directions with respect to BGP measurement of water, with a special focus on ultra-low nutrient drinking water produced by $\mathrm{RO}$ and remineralisation, as follows:

- Further development of the bacterial growth potential method using flow cytometry for ultra-low nutrient drinking water produced by RO and remineralisation (Chapter 2 and 3$)$.

- On-site application of the improved BGP method to compare water produced by RO and remineralisation with that of conventionally treated drinking water that is currently distributed in the Netherlands (Chapter 2, 3 and 4).

- Exploring the combination of BGP measurement using FCM and other biological stability assessment methods, namely: BGP measurement using ATP and bacterial community composition using $16 \mathrm{~S}$ rRNA gene sequencing, to obtain in-depth understanding of bacterial growth characteristics of ultra-low nutrient water treated by RO and remineralisation (Chapter 4 and 5). 
The following sections highlight the main findings that can be drawn from each aforementioned aspect.

\subsubsection{Bacterial growth potential method development}

The main objective of this dissertation was to further develop the current BGP method, using FCM, for the assessment of biological stability of ultra-low nutrient water produced by RO and remineralisation (i.e., RO-treated water).

The development of methodological aspects of the BGP method showed the following:

- FCM analysis is reproducible for RO-treated water where changes in bacterial cell count and fluorescence fingerprints could be detected after on-site post-treatment processes or laboratory-adjustments of RO permeate samples (e.g., standard nutrient addition) (Chapter 2, 3, and 4).

- The current limit of detection of the BGP method was suitable for drinking water produced by conventional treatment means such as sand filtration and activated carbon filtration. However, the limit of detection was significantly higher than the BGP of water produced by RO and remineralisation, urging the need for a lower limit of detection in order to be able to reliably measure the BGP of ultra-low nutrient water. This has been achieved by producing ultra-pure blank water after adjusting the chemical content of RO permeate (at the laboratory) to levels similar to that in drinking water (Chapter 2). Moreover, the protocol proposed in this chapter to produce an ultra-pure blank can be applied to other types of water (e.g., distilled water).

- The purpose of pre-treatment of water samples in traditional biological stability assessment methods was to inactivate indigenous bacteria prior to inoculating with a controlled consortium of pure bacterial strains. The development of analytical methods to measure bacteria in water (e.g., FCM and ATP) allowed for using natural bacterial consortium as inoculum in the BGP test, as a result of which some researchers proposed new methods omitting any pre-treatment step. In this dissertation, however, pre-treatment was essential for samples of ultra-low nutrient water produced by RO and remineralisation to ensure the reliability of BGP results. For instance, sloughing of bacterial cells from the treatment unit was observed under certain conditions, resulting in initial cell counts higher than the maximum growth (Chapter 2). Commonly, available methods of biological stability assessment consider pre-treatment by pasteurisation or membrane filtration. The latter had a pronounced negative influence on BGP of ultra-low nutrient water due to leaching of organic compounds from membrane filters despite extensive flushing prior to use. On the other hand, no significant effect of pasteurisation on the nutrient content of water was observed for ultra-low nutrient water as well as for conventionally treated drinking water tested in this study (Chapter 3). 
- Inoculating water samples with a natural bacterial consortium is essential for BGP measurement to ensure complete consumption of a wide range of organic nutrients, and thus reliable BGP results. Due to the ultra-low nutrient content of water produced by reverse osmosis and remineralisation, inoculating this type of water with bacteria originating from conventionally treated drinking water resulted in undesired addition of nutrients, especially at high inoculum concentrations (Chapter 2). Alternatively, inoculating ultra-low nutrient water produced by RO and remineralisation with bacteria originating from the same water type was evaluated, where these bacteria were found to have limited ability to utilise some types of organic compounds, more specifically organic carbon with complex molecular properties (Chapter 3). Therefore, throughout this dissertation, an inoculum concentration of $10 \times 10^{3}$ intact cells $/ \mathrm{mL}$ originating from conventionally treated drinking water was considered since insignificant nutrient addition was observed at this concentration (Chapter 2).

- The developed BGP method is useful for the identification of factors and nutrients limiting bacterial growth in ultra-low nutrient water produced by $\mathrm{RO}$ and remineralisation (Chapter 4).

- The multi-parametric approach based on the combination of BGP measurement, nutrient analysis, and 16S rRNA gene sequencing offers in-depth insight into bacterial growth characteristics, as well as improving our understanding of why growth occurs (limiting nutrients) and which bacteria grow (dominant bacterial genera) in any type of water studied (Chapter 4).

- Measuring BGP using both FCM and ATP is useful to obtain an in-depth understanding of the growth characteristics of water as additional complementary information can be obtained from the combined tests. In this dissertation, the response of BGP measured by FCM to the limitation of inorganic nutrients in water was more pronounced than that of BGP measured by ATP, where a cell-yield from phosphate was estimated at $0.70 \pm 0.05 \times 10^{9} \mathrm{cells} / \mu \mathrm{g} \mathrm{PO}_{4}-\mathrm{P}($ Chapter 5).

\subsubsection{Influence of reverse osmosis treatment on biological stability}

Application of the developed BGP method at a water treatment plant producing drinking water from anaerobic groundwater in the Netherlands, showed the following:

- The type of water treatment plays an important role in determining the biological stability of the final product water. Long term monitoring at a water treatment utility producing drinking water from anaerobic groundwater showed that treatment based on RO and post-treatment including remineralisation (i.e., RO-based treatment) has substantially reduced $(>75 \%)$ the BGP compared with conventional treatment means 
(Chapter 3 and 4). This reduction in BGP was mainly associated with the significant removal of organic and inorganic growth-promoting nutrients achieved by $\mathrm{RO}$ filtration (>99\% removal) (Chapter 4).

- Within RO-based treatment, BGP was negatively influenced by post-treatment, where BGP of water samples collected directly after RO filtration (RO permeate) increased by $100 \%$ after the post-treatment processes as observed during long term monitoring (Chapter 3). This increase in BGP was accompanied by an increase in organic and inorganic nutrients due to the post-treatment processes (Chapter 4). Remineralisation by calcite contactors was the main source of additional nutrients, which was very high at the beginning of operating the units with fresh calcite grains (Chapter 2).

- No significant seasonal variations in BGP were observed from drinking water produced by advanced RO-based treatment (i.e., RO and post-treatment including remineralisation) or from conventional treatment (Chapter 3 ). This is associated with the relatively stable nature of groundwater (e.g., temperature, chemical composition, and organic content).

- For both types of treatment, organic carbon was the bacterial growth-limiting nutrient in the final water, even at very low concentrations of phosphate $(<1 \mu \mathrm{g} / \mathrm{L}$ $\left.\mathrm{PO}_{4}-\mathrm{P}\right)$ (Chapter 4).

- In addition to its effect on BGP, the type of water treatment also shaped the bacterial community of the finished treated water. Several bacterial genera were common between the anaerobic groundwater source water and the finished conventionally treated water. On the other hand, the bacterial genera identified in finished ROtreated water were mainly introduced during the post-treatment processes, with no genera shared with the source anaerobic groundwater (Chapter 4).

The aforementioned observations clearly demonstrate that applying RO filtration for producing drinking water is promising to considerably limit bacterial growth in water and the associated health and operational problems. 


\subsection{Future insights}

Achieving biological stability in non-chlorinated water distribution systems requires the production of drinking water that does not support excessive bacterial growth. RO filtration is a superior barrier for bacteria and growth-promoting nutrients in water, as a result of which RO-treated has a high degree of biological stability. The following sections present insights for future research.

\subsubsection{Methodological aspects}

In this dissertation, the current BGP method was further developed for ultra-low nutrient water produced by RO and remineralisation. The developed BGP method can, however, be applied for other ultra-low nutrient water types (e.g., distilled water), where further methodological developments could be considered. First of all, the limit of detection of the BGP method might be further lowered by testing different types of water as a blank other than RO permeate (proposed in this dissertation), for instance, distilled water produced at the laboratory under controlled conditions. Moreover, further investigation on the impact of various steps in the procedure can be carried out, such as glassware materials and methods of collecting aliquots from incubated glassware.

Another factor that could be critical for other types of ultra-low nutrient water is the contamination caused by inoculation, even though this effect was negligible for the inoculum concentration used in this dissertation. Preparing AOC-free inoculum could be, therefore, considered, where regular validation is required by testing the ability of this inoculum to consume readily available as well as complex organic carbon in addition to performing 16S rRNA gene sequencing analysis for diversity control.

The multi-parametric approach proposed in this dissertation to evaluate biological stability of drinking water offers in-depth insight into the stability and changes in microbiological water quality between different treatment lines considering bacterial growth potential assessment, nutrient measurement, and bacterial community composition analysis. The multi-parametric approach is recommended as a complementary approach when water quality deterioration is detected during regular monitoring at both the treatment and distribution stage of water production.

It is important to highlight that bacterial growth due to the presence of methane was not considered in this research, where the proposed BGP method was carried out under aerobic conditions, allowing methane to escape during testing. The development of a method to measure BGP under anaerobic conditions is required to assess the impact of methane, which represents a challenge due to the volatile nature of methane. 


\subsubsection{Practical standpoint}

The developed BGP method in this dissertation is useful for practical applications, either as a standalone test or in combination with other analyses (i.e., nutrient measurement and bacterial community composition). The proposed method can be applied for regular monitoring of drinking water quality either at the treatment location or in the distribution network, where the frequency of monitoring is dependent on the source water used, as no seasonal variation was observed during this research for drinking water produced from anaerobic groundwater. In addition, this approach is useful for in-depth investigation of water quality deterioration or for future research purposes. For instance, the application of the proposed methods in this dissertation to a drinking water production site in the Netherlands revealed shortcomings of post-treatment processes that led to the deterioration of RO permeate quality. Therefore, some measures are recommended to mitigate the negative influences of post-treatment, such as using high quality calcite grains for remineralisation to prevent the introduction of organic and inorganic nutrients, and more frequent maintenance of the aeration towers to reduce internal bacterial growth on the packing material, or even investigating alternative remineralisation and aeration methodologies (e.g., extracting bivalent ions from RO concentrate, membrane aeration). Moreover, the findings of this dissertation were based a pilot-scale RO treatment scheme, and more work is needed to validate them on a full-scale treatment plant employing RO filtration.

Looking from a different angle, the comparison between conventional and RO-based treatment in this dissertation demonstrated the possible quantitative and qualitative control of drinking water microbiology by using RO membranes as an absolute barrier for cells. Therefore, a reasonable future vision could be to manage the microbial ecology of drinking water distribution systems by introducing probiotic microbes through post RO treatment to occupy the niches and form a predictable and predefined microbial ecology in the distribution system.

And lastly, this dissertation focused on drinking water at the production site. However, it is highly recommended to carry out further research to investigate the effect of RO-treated drinking water on microbial growth and ecology in the current distribution system fed with conventional drinking water, with a special focus on the transition period when switching from conventionally treated drinking water to RO-treated water. 

A

Abushaban, A., Salinas-Rodriguez, S.G., Mangal, M.N., Mondal, S., Goueli, S.A., Knezev, A., Vrouwenvelder, J.S., Schippers, J.C., Kennedy, M.D., 2019. ATP measurement in seawater reverse osmosis systems: Eliminating seawater matrix effects using a filtration-based method. Desalination 453, 1-9. https://doi.org/10.1016/j.desal.2018.11.020

Amon, R.M.W., Benner, R., 1996. Bacterial utilization of different size classes of dissolved organic matter. Limnology and Oceanography 41, 41-51. https://doi.org/10.4319/10.1996.41.1.0041

Anis, S.F., Hashaikeh, R., Hilal, N., 2019. Reverse osmosis pretreatment technologies and future trends: A comprehensive review. Desalination 452, 159-195. https://doi.org/10.1016/j.desal.2018.11.006

B

Beauté, J., Zucs, P., Jong, B.d., 2013. On behalf of the European Legionnaires' Disease Surveillance Network, Legionnaires' disease in Europe, 2009-2010.

Eurosurveillance 18, 6-12. http://dx.doi.org/10.25646/1346

Belila, A., El-Chakhtoura, J., Alotaibi, N., Muyzer, G., Gonzalez-Gil, G., Saikaly, P., van Loosdrecht, M., Vrouwenvelder, J.S., 2016. Bacterial community structure and variation in a full-scale seawater desalination plant for drinking water production. Water Research 94, 62-72. https://doi.org/10.1016/j.watres.2016.02.039

Bereschenko, L.A., Hornstra, L., 2014. Inventarisatie nagroeiproblematiek Oasen en oorzaak lagere biologische stabiliteit zs De Laak. KWR, report, BTO 2014.206(s), Nieuwegein, the Netherlands.

Berg, J.M., Tymoczko, J.L., Stryer, L., 2002. Glycolysis is an energy-conversion pathway in many organisms. pp. 613-633 in: Moran, S., Hadler, G.L., Zimmerman, P. (Eds), Biochemistry 5th ed., W.H. Freeman, New York.

Berry, D., Xi, C., Raskin, L., 2006. Microbial ecology of drinking water distribution systems. Current Opinion in Biotechnology 17, 297-302. https://doi.org/10.1016/j.copbio.2006.05.007

Birnhack, L., Voutchkov, N., Lahav, O., 2011. Fundamental chemistry and engineering aspects of post-treatment processes for desalinated water - A review. Desalination 273, 6-22. https://doi.org/10.1016/j.desal.2010.11.011

Bonadonna, L., Briancesco, R., Della Libera, S., Lacchetti, I., Paradiso, R., Semproni, M., 2009. Microbial characterization of water and biofilms in drinking water distribution systems at sport facilities. Central European journal of public health 17, 99-102.

Boraston, A.B., Bolam, D.N., Gilbert, H.J., Davies, G.J., 2004. Carbohydrate-binding modules: Fine-tuning polysaccharide recognition. Biochemical Journal 382, 769 781. https://doi.org/10.1042/BJ20040892 
Boström, B., Törnblom, E., 1990. Bacterial production, heat production and ATP-turnover in shallow marine sediments. Thermochimica Acta 172, 147-156. https://doi.org/10.1016/0040-6031(90)80568-J

Bruns, A., Rohde, M., Berthe-Corti, L., 2001. Muricauda ruestringensis gen. nov., sp. nov., a facultatively anaerobic, appendaged bacterium from German North Sea intertidal sediment. International Journal of Systematic and Evolutionary Microbiology 51, 1997-2006. https://doi.org/10.1099/00207713-51-6-1997

Bucheli-Witschel, M., Kötzsch, S., Darr, S., Widler, R., Egli, T., 2012. A new method to assess the influence of migration from polymeric materials on the biostability of drinking water. Water Research 46, 4246-4260. https://doi.org/10.1016/j.watres.2012.05.008

Buysschaert, B., Vermijs, L., Naka, A., Boon, N., De Gusseme, B., 2018. Online flow cytometric monitoring of microbial water quality in a full-scale water treatment plant. npj Clean Water 1, 16. https://doi.org/10.1038/s41545-018-0017-7

C, D

Church, M.J., Hutchins, D.A., Ducklow, H.W., 2000. Limitation of bacterial growth by dissolved organic matter and iron in the Southern Ocean. Applied and Environmental Microbiology 66, 455-466. https://doi.org/10.1128/aem.66.2.455$\underline{466.2000}$

Colwell, R.R., 2004. Infectious disease and environment: Cholera as a paradigm for waterborne disease. International Microbiology 7, 285-289.

de Vet, W.W.J.M., van Genuchten, C.C.A., van Loosdrecht, M.C.M., van Dijk, J.C., 2010. Water quality and treatment of river bank filtrate. Drinking Water Engineering and Science 3, 79-90. https://doi.org/10.5194/dwes-3-79-2010

Dilworth, M.J., Glenn, A.R., 1999. Problems of adverse $\mathrm{pH}$ and bacterial strategies to combat it. pp. 4-18 in: Chadwick, D.J., Cardew, G. (Eds), Bacterial Responses to $\mathrm{pH}$, WILEY, Chichester.

DiSpirito, A.A., Semrau, J.D., Murrell, J.C., Gallagher, W.H., Dennison, C., Vuilleumier, S., 2016. Methanobactin and the link between copper and bacterial methane oxidation. Microbiology and Molecular Biology Reviews 80, 387-409. https://doi.org/10.1128/MMBR.00058-15

Dixon, M.B., Qiu, T., Blaikie, M., Pelekani, C., 2012. The application of the bacterial regrowth potential method and fow cytometry for biofouling detection at the Penneshaw desalination plant in south Australia. Desalination 284, 245-252. https://doi.org/10.1016/j.desal.2011.09.006

Durand, M., Kawashima, R., 1980. Influence of minerals in rumen microbial digestion. pp. 375-408 in: Ruckebusch, Y., Thivend, P. (Eds), Digestive Physiology and Metabolism in Ruminants, Springer, Dordrecht.

\section{$\mathbf{E}, \mathbf{F}$}

Egli, T., 2009. Nutrition, Microbial. pp. 308-324 in: Schaechter, M. (Eds), Encyclopedia of Microbiology (Third Edition), Academic Press, Oxford.

Elhadidy, A.M., van Dyke, M.I., Peldszus, S., Huck, P.M., 2016. Application of flow cytometry to monitor assimilable organic carbon (AOC) and microbial community 
changes in water. Journal of Microbiological Methods 130, 154-163.

https://doi.org/10.1016/j.mimet.2016.09.009

Escobar, I.C., Hong, S., Randall, A.A., 2000. Removal of assimilable organic carbon and biodegradable dissolved organic carbon by reverse osmosis and nanofiltration membranes. Journal of Membrane Science 175, 1-17. https://doi.org/10.1016/S0376$\underline{7388(00) 00398-7}$

Eydal, H.S.C., Pedersen, K., 2007. Use of an ATP assay to determine viable microbial biomass in Fennoscandian Shield groundwater from depths of 3-1000 m. Journal of Microbiological Methods 70, 363-373. https://doi.org/10.1016/j.mimet.2007.05.012

Fane, A.G., Wang, R., Hu, M.X., 2015. Synthetic membranes for water purification: Status and future. Angewandte Chemie International Edition 54, 3368-3386. https://doi.org/10.1002/anie.201409783

Farhat, N., Hammes, F., Prest, E., Vrouwenvelder, J., 2018. A uniform bacterial growth potential assay for different water types. Water Research 142, 227-235. https://doi.org/10.1016/j.watres.2018.06.010

Fujikawa, H., Kai, A., Morozumi, S., 2004. A new logistic model for Escherichia coli growth at constant and dynamic temperatures. Food Microbiology 21, 501-509. https://doi.org/10.1016/j.fm.2004.01.007

Fujioka, T., Hoang, A.T., Aizawa, H., Ashiba, H., Fujimaki, M., Leddy, M., 2018. Realtime online monitoring for assessing removal of bacteria by reverse osmosis. Environmental Science \& Technology Letters 5, 389-393. https://doi.org/10.1021/acs.estlett.8b00200

Fujioka, T., Ueyama, T., Mingliang, F., Leddy, M., 2019. Online assessment of sand filter performance for bacterial removal in a full-scale drinking water treatment plant. Chemosphere 229, 509-514. https://doi.org/10.1016/j.chemosphere.2019.04.197

\section{G}

Garrity, G.M., Holt, J.G., Spieck, E., Bock, E., Johnson, D.B., Spring, S., Schleifer, K.-H., Maki, J.S., 2001. Phylum BVIII. Nitrospirae phy. nov. pp. 451-464 in: Boone, D.R., Castenholz, R.W., Garrity, G.M. (Eds), Bergey's manual ${ }^{\circledR}$ of systematic bacteriology, Springer, New York, NY.

Geise, G.M., Lee, H.-S., Miller, D.J., Freeman, B.D., McGrath, J.E., Paul, D.R., 2010. Water purification by membranes: The role of polymer science. Journal of Polymer Science Part B: Polymer Physics 48, 1685-1718. https://doi.org/10.1002/polb.22037

Giorgio, P.A.d., Cole, J.J., 1998. Bacterial growth efficiency in natural aquatic systems. Annual Review of Ecology and Systematics 29, 503-541.

https://doi.org/10.1146/annurev.ecolsys.29.1.503

Gopal, K., Tripathy, S.S., Bersillon, J.L., Dubey, S.P., 2007. Chlorination byproducts, their toxicodynamics and removal from drinking water. Journal of Hazardous Materials 140, 1-6. https://doi.org/10.1016/j.jhazmat.2006.10.063

Graham, D.W., Chaudhary, J.A., Hanson, R.S., Arnold, R.G., 1993. Factors affecting competition between type I and type II methanotrophs in two-organism, continuousflow reactors. Microbial Ecology 25, 1-17. https://doi.org/10.1007/BF00182126 
Gray, C.T., Wimpenny, J.W., Mossman, M.R., 1966. Regulation of metabolism in facultative bacteria: II. Effects of aerobiosis, anaerbiosis and nutrition on the formation of Krebs cycle enzymes in Escherchia coli. Biochimica et Biophysica Acta (BBA) - General Subjects 117, 33-41. https://doi.org/10.1016/03044165(66)90149-8

Guo, H., van der Mark, E., Schaap, P., Bakker, G., Zaadstra, E., 2014. Batchexperimenten voor de analyse van bacteriegroei in distributienetten. H2O-Online.

H

Hallbeck, L., Pedersen, K., 2014. The Family Gallionellaceae. pp. 853-858 in: Rosenberg, E., DeLong, E.F., Lory, S., Stackebrandt, E., Thompson, F. (Eds), The Prokaryotes: Alphaproteobacteria and Betaproteobacteria, Springer, Berlin, Heidelberg.

Hammes, F., Berger, C., Köster, O., Egli, T., 2010a. Assessing biological stability of drinking water without disinfectant residuals in a full-scale water supply system. Journal of Water Supply: Research and Technology - AQUA 59, 31-40. https://doi.org/10.2166/aqua.2010.052

Hammes, F., Goldschmidt, F., Vital, M., Wang, Y., Egli, T., 2010b. Measurement and interpretation of microbial adenosine tri-phosphate (ATP) in aquatic environments. Water Research 44, 3915-3923. https://doi.org/10.1016/j.watres.2010.04.015

Hammes, F.A., Egli, T., 2005. New method for assimilable organic carbon determination using flow-cytometric enumeration and a natural microbial consortium as inoculum. Environmental Science and Technology 39, 3289-3294. https://doi.org/10.1021/es048277c

Hanson, R.S., Hanson, T.E., 1996. Methanotrophic bacteria. Microbiological Reviews 60, 439-471.

Hasson, D., Bendrihem, O., 2006. Modeling remineralization of desalinated water by limestone dissolution. Desalination 190, 189-200. http://dx.doi.org/10.1016/j.desal.2005.09.003

Havelaar, A.H., De Hollander, A.E., Teunis, P.F., Evers, E.G., van Kranen, H.J., Versteegh, J.F., van Koten, J.E., Slob, W., 2000. Balancing the risks and benefits of drinking water disinfection: disability adjusted life-years on the scale. Environmental Health Perspectives 108, 315-321.

Hedrich, S., Schlömann, M., Johnson, D.B., 2011. The iron-oxidizing proteobacteria. Microbiology 157, 1551-1564. https://doi.org/10.1099/mic.0.045344-0

Hem, L.J., Efraimsen, H., 2001. Assimilable organic carbon in molecular weight fractions of natural organic matter. Water Research 35, 1106-1110. https://doi.org/10.1016/S0043-1354(00)00354-7

Herbert, D., 1961. The chemical composition of micro-organisms as a function of their environment. Symposium of the Society General Microbiology 11, 391-416.

Herrmann, M., Wegner, C.-E., Taubert, M., Geesink, P., Lehmann, K., Yan, L., Lehmann, R., Totsche, K.U., Küsel, K., 2019. Predominance of Cand. Patescibacteria in groundwater is caused by their preferential mobilization from soils and flourishing under oligotrophic conditions. Frontiers in Microbiology 10, 1407. https://doi.org/10.3389/fmicb.2019.01407 
Hespell, R.B., Bryant, M.P., 1979. Efficiency of Rumen Microbial Growth: Influence of some Theoretical and Experimental Factors on YATP. Journal of Animal Science 49, 1640-1659. https://doi.org/10.2527/jas1979.4961640x

Hijnen, W., Schurer, R., Bahlman, J.A., Ketelaars, H., Italiaander, R., van der Wal, A., van der Wielen, P., 2018. Slowly biodegradable organic compounds impact the biostability of non-chlorinated drinking water produced from surface water. Water Research 129, 240-251. https://doi.org/10.1016/j.watres.2017.10.068

Hoeffler, U., 1977. Enzymatic and hemolytic properties of Propionibacterium acnes and related bacteria. Journal of Clinical Microbiology 6, 555-558.

Hong, S., Escobar, I.C., Hershey-Pyle, J., Hobbs, C., Cho, J., 2005. Biostability characterization in a full-scale hybrid NF/RO treatment system. Journal - American Water Works Association 97, 101-110.

Hrmova, M., Fincher, G.B., 2009. Plant and microbial enzymes involved in the depolymerization of (1,3)- $\beta$-d-glucans and related polysaccharides. pp. 119-170 in: Bacic, A., Fincher, G.B., Stone, B.A. (Eds), Chemistry, Biochemistry, and Biology of 1-3 Beta Glucans and Related Polysaccharides, Academic Press, San Diego.

Hu, J.Y., Wang, Z.S., Ng, W.J., Ong, S.L., 1999. The effect of water treatment processes on the biological stability of potable water. Water Research 33, 2587-2592. https://doi.org/10.1016/S0043-1354(98)00482-5

Huber, S.A., Balz, A., Abert, M., Pronk, W., 2011. Characterisation of aquatic humic and non-humic matter with size-exclusion chromatography - organic carbon detection organic nitrogen detection (LC-OCD-OND). Water Research 45, 879-885. https://doi.org/10.1016/j.watres.2010.09.023

Huck, P.M., 1990. Measurement of biodegradable organic matter and bacterial growth potential in drinking water. Journal - American Water Works Association 82, 78-86. https://doi.org/10.1002/j.1551-8833.1990.tb06995.x

\section{I, J}

Ihssen, J., Jovanovic, N., Sirec, T., Spitz, U., 2021. Real-time monitoring of extracellular ATP in bacterial cultures using thermostable luciferase. PLoS ONE 16, e0244200. https://doi.org/10.1371/journal.pone.0244200

Ivone, V.-M., Conceição, E., Olga C., N., Célia M., M., 2013. Bacterial diversity from the source to the tap: A comparative study based on 16S rRNA gene-DGGE and culturedependent methods. FEMS Microbiology Ecology 83, 361-374. https://doi.org/10.1111/1574-6941.12002

Jacobson, J.D., Kennedy, M.D., Amy, G., Schippers, J.C., 2009. Phosphate limitation in reverse osmosis: An option to control biofouling? Desalination and Water Treatment 5, 198-206. https://doi.org/10.5004/dwt.2009.578

Jansson, M., 1988. Phosphate uptake and utilization by bacteria and algae. 177-189. https://doi.org/10.1007/978-94-009-3109-1_11

Joret, J.C., Levi, Y., Volk, C., 1991. Biodegradable dissolved organic carbon (BDOC) content of drinking water and potential regrowth of bacteria. Water Science and Technology 24, 95-101. 
$\mathbf{K}$

Kaplan, L.A., Bott, T.L., Reasoner, D.J., 1993. Evaluation and simplification of the assimilable organic carbon nutrient bioassay for bacterial growth in drinking water. Applied and Environmental Microbiology 59, 1532-1539.

Karakashev, D., Batstone, D.J., Trably, E., Angelidaki, I., 2006. Acetate oxidation is the dominant methanogenic pathway from acetate in the absence of methanosaetaceae. Applied and Environmental Microbiology 72, 5138-5141. https://doi.org/10.1128/aem.00489-06

Khan, E., Subramania-Pillai, S., 2006. Effect of leaching from filters on laboratory analyses of collective organic constituents. Water Environment Federation 2006, 901-918. http://dx.doi.org/10.2175/1938647067837499747

Kitzinger, K., Koch, H., Lücker, S., Sedlacek, C.J., Herbold, C., Schwarz, J., Daebeler, A., Mueller, A.J., Lukumbuzya, M., Romano, S., Leisch, N., Karst, S.M., Kirkegaard, R., Albertsen, M., Nielsen, P.H., Wagner, M., Daims, H., 2018. Characterization of the first "Candidatus Nitrotoga" isolate reveals metabolic versatility and separate evolution of widespread nitrite-oxidizing bacteria. mBio 9, e01186-18. https://doi.org/10.1128/mBio.01186-18

Knowles, C.J., Smith, L., 1970. Measurements of ATP levels of intact Azotobacter vinelandii under different conditions. Biochimica et Biophysica Acta (BBA) Bioenergetics 197, 152-160. https://doi.org/10.1016/0005-2728(70)90026-5

Koch, H., Lücker, S., Albertsen, M., Kitzinger, K., Herbold, C., Spieck, E., Nielsen, P.H., Wagner, M., Daims, H., 2015. Expanded metabolic versatility of ubiquitous nitriteoxidizing bacteria from the genus Nitrospira. Proceedings of the National Academy of Sciences 112, 11371-11376. https://doi.org/10.1073/pnas.1506533112

L

Lahav, O., Birnhack, L., 2007. Quality criteria for desalinated water following posttreatment. Desalination 207, 286-303. https://doi.org/10.1016/j.desal.2006.05.022

Lautenschlager, K., Hwang, C., Liu, W.-T., Boon, N., Köster, O., Vrouwenvelder, H., Egli, T., Hammes, F., 2013. A microbiology-based multi-parametric approach towards assessing biological stability in drinking water distribution networks. Water Research 47, 3015-3025. https://doi.org/10.1016/j.watres.2013.03.002

Learbuch, K.L.G., Lut, M.C., Liu, G., Smidt, H., van der Wielen, P.W.J.J., 2019. Legionella growth potential of drinking water produced by a reverse osmosis pilot plant. Water Research 157, 55-63. https://doi.org/10.1016/j.watres.2019.03.037

Lebaron, P., Servais, P., Agogué, H., Courties, C., Joux, F., 2001. Does the high nucleic acid content of individual bacterial cells allow us to discriminate between active cells and inactive cells in aquatic systems? Applied and Environmental Microbiology 67, 1775-1782. https://doi.org/10.1128/AEM.67.4.1775-1782.2001

LeChevallier, M.W., Welch, N.J., Smith, D.B., 1996. Full-scale studies of factors related to coliform regrowth in drinking water. Applied and Environmental Microbiology $62,2201-2211$.

Lehtola, M.J., Miettinen, I.T., Vartiainen, T., Martikainen, P.J., 1999. A new sensitive bioassay for determination of microbially available phosphorus in water. Applied 
and Environmental Microbiology 65, 2032-2034.

https://doi.org/10.1128/AEM.65.5.2032-2034.1999

Lehtola, M.J., Miettinen, I.T., Vartiainen, T., Martikainen, P.J., 2002. Changes in content of microbially available phosphorus, assimilable organic carbon and microbial growth potential during drinking water treatment processes. Water Research 36, 3681-3690. https://doi.org/10.1016/S0043-1354(02)00100-8

Li, C., Ling, F., Zhang, M., Liu, W.-T., Li, Y., Liu, W., 2017a. Characterization of bacterial community dynamics in a full-scale drinking water treatment plant. Journal of Environmental Sciences 51, 21-30. https://doi.org/10.1016/j.jes.2016.05.042

Li, Q., Yu, S., Li, L., Liu, G., Gu, Z., Liu, M., Liu, Z., Ye, Y., Xia, Q., Ren, L., 2017 b. Microbial communities shaped by treatment processes in a drinking water treatment plant and their contribution and threat to drinking water safety. Frontiers in Microbiology 8, 2465. https://doi.org/10.3389/fmicb.2017.02465

Liao, X., Chen, C., Wang, Z., Chang, C.H., Zhang, X., Xie, S., 2015. Bacterial community change through drinking water treatment processes. International Journal of Environmental Science and Technology 12, 1867-1874. https://doi.org/10.1007/s13762-014-0540-0

Lipponen, M.T.T., Martikainen, P.J., Vasara, R.E., Servomaa, K., Zacheus, O., Kontro, M.H., 2004. Occurrence of nitrifiers and diversity of ammonia-oxidizing bacteria in developing drinking water biofilms. Water Research 38, 4424-4434. https://doi.org/10.1016/j.watres.2004.08.021

Liu, G., Lut, M.C., Verberk, J.Q.J.C., van Dijk, J.C., 2013a. A comparison of additional treatment processes to limit particle accumulation and microbial growth during drinking water distribution. Water Research 47, 2719-2728. https://doi.org/10.1016/j.watres.2013.02.035

Liu, G., van der Mark, E.J., Verberk, J.Q.J.C., van Dijk, J.C., 2013b. Flow cytometry total cell counts: A field study assessing microbiological water quality and growth in unchlorinated drinking water distribution systems. BioMed Research International 2013, 595872. http://dx.doi.org/10.1155/2013/595872

Liu, G., Verberk, J.Q.J.C., van Dijk, J.C., 2013c. Bacteriology of drinking water distribution systems: An integral and multidimensional review. Applied Microbiology and Biotechnology 97, 9265-9276. https://doi.org/10.1007/s00253$\underline{013-5217-y}$

Liu, G., Zhang, Y., Knibbe, W.J., Feng, C., Liu, W., Medema, G., van der Meer, W., 2017. Potential impacts of changing supply-water quality on drinking water distribution: A review. Water Research 116, 135-148. https://doi.org/10.1016/j.watres.2017.03.031

Liu, G., Zhang, Y., Liu, X., Hammes, F., Liu, W.-T., Medema, G., Wessels, P., van der Meer, W., 2020. 360-degree distribution of biofilm quantity and community in an operational unchlorinated drinking water distribution pipe. Environmental Science \& Technology 54, 5619-5628. https://doi.org/10.1021/acs.est.9b06603

Liu, G., Zhang, Y., van der Mark, E., Magic-Knezev, A., Pinto, A., van den Bogert, B., Liu, W., van der Meer, W., Medema, G., 2018. Assessing the origin of bacteria in tap water and distribution system in an unchlorinated drinking water system by SourceTracker using microbial community fingerprints. Water Research 138, 86-96. https://doi.org/10.1016/j.watres.2018.03.043 
Liu, X., Wang, J., Liu, T., Kong, W., He, X., Jin, Y., Zhang, B., 2015. Effects of Assimilable Organic Carbon and Free Chlorine on Bacterial Growth in Drinking Water. PLoS ONE 10, e0128825. 10.1371/journal.pone.0128825

$\mathbf{M}, \mathbf{N}$

Madaeni, S.S., 1999. The application of membrane technology for water disinfection. Water Research 33, 301-308. https://doi.org/10.1016/S0043-1354(98)00212-7

Magic-Knezev, A., van der Kooij, D., 2004. Optimisation and significance of ATP analysis for measuring active biomass in granular activated carbon filters used in water treatment. Water Research 38, 3971-3979. https://doi.org/10.1016/j.watres.2004.06.017

Martiny, A.C., Albrechtsen, H.-J., Arvin, E., Molin, S., 2005. Identification of bacteria in biofilm and bulk water samples from a nonchlorinated model drinking water distribution system: Detection of a large nitrite-oxidizing population associated with Nitrospira spp. Applied and Environmental Microbiology 71, 8611-8617. https://doi.org/10.1128/AEM.71.12.8611-8617.2005

Meckes, M.C., Haught, R.C., Kelty, K., Blannon, J.C., Cmehil, D., 2007. Impact on water distribution system biofilm densities from reverse osmosis membrane treatment of supply water. Journal of Environmental Engineering and Science 6, 449-454. https://doi.org/10.1139/s06-062

Mempin, R., Tran, H., Chen, C., Gong, H., Kim Ho, K., Lu, S., 2013. Release of extracellular ATP by bacteria during growth. BMC Microbiology 13, 301. https://doi.org/10.1186/1471-2180-13-301

Miettinen, I.T., Vartiainen, T., Martikainen, P.J., 1997. Phosphorus and bacterial growth in drinking water. Applied and Environmental Microbiology 63, 3242-3245. https://doi.org/10.1128/AEM.63.8.3242-3245.1997

Mikkers, Y., Magic-Knezev, A., 2014. Wat hebben we geleerd van drie jaar onderzoek naar waterkwaliteit in het leidingnet? H2O-Online

Narayan, V.V., Hatha, M.A., Morgan, H.W., Rao, D., 2008. Isolation and characterization of aerobic thermophilic bacteria from the Savusavu hot springs in Fiji. Microbes and Environments 23, 350-352. https://doi.org/10.1264/jsme2.ME08105

Nescerecka, A., Juhna, T., Hammes, F., 2018. Identifying the underlying causes of biological instability in a full-scale drinking water supply system. Water Research 135, 11-21. https://doi.org/10.1016/j.watres.2018.02.006

Nicol, G.W., Glover, L.A., Prosser, J.I., 2003. Molecular analysis of methanogenic archaeal communities in managed and natural upland pasture soils. Global Change Biology 9, 1451-1457. https://doi.org/10.1046/j.1365-2486.2003.00673.x

$\mathbf{P}$

Page, D.W., van Leeuwen, J.A., Spark, K.M., Drikas, M., Withers, N., Mulcahy, D.E., 2002. Effect of alum treatment on the trihalomethane formation and bacterial regrowth potential of natural and synthetic waters. Water Research 36, 4884-4892. https://doi.org/10.1016/S0043-1354(02)00218-X

Park, J.W., Kim, H.C., Meyer, A.S., Kim, S., Maeng, S.K., 2016. Influences of NOM composition and bacteriological characteristics on biological stability in a full-scale 
drinking water treatment plant. Chemosphere 160, 189-198.

https://doi.org/10.1016/j.chemosphere.2016.06.079

Park, S.K., Hu, J.Y., 2010. Assessment of the extent of bacterial growth in reverse osmosis system for improving drinking water quality. Journal of Environmental Science and Health, Part A 45, 968-977. https://doi.org/10.1080/10934521003772386

Patnaik, P., 2003. McComb, K., Penikas, D. (Eds), Handbook of Inorganic Chemicals, McGraw-Hill, New York.

Peng, W., Escobar, I.C., 2003. Rejection efficiency of water quality parameters by reverse osmosis and nanofiltration membranes. Environmental Science \& Technology 37, 4435-4441.

Percherancier, H., Volat, B., Montuelle, B., 1996. Testing the biodegradability of wastewater treatment plant outfalls: Role of bacterial inocula. Water Science and Technology 33, 221-229. https://doi.org/10.1016/0273-1223(96)00331-9

Percival, E.G.V., Ross, A.G., 1951. 156. The constitution of laminarin. Part II. The soluble laminarin of Laminaria digitata. Journal of the Chemical Society 720-726. https://doi.org/10.1039/jr9510000720

Pla, M.L., Oltra, S., Esteban, M.D., Andreu, S., Palop, A., 2015. Comparison of primary models to predict microbial growth by the plate count and absorbance methods. BioMed Research International 2015, 365025. https://doi.org/10.1155/2015/365025

Prest, E.I., El-Chakhtoura, J., Hammes, F., Saikaly, P.E., van Loosdrecht, M.C.M., Vrouwenvelder, J.S., 2014. Combining flow cytometry and 16S rRNA gene pyrosequencing: A promising approach for drinking water monitoring and characterization. Water Research 63, 179-189. https://doi.org/10.1016/j.watres.2014.06.020

Prest, E.I., Hammes, F., Kötzsch, S., van Loosdrecht, M.C.M., Vrouwenvelder, J.S., 2013. Monitoring microbiological changes in drinking water systems using a fast and reproducible flow cytometric method. Water Research 47, 7131-7142. https://doi.org/10.1016/j.watres.2013.07.051

Prest, E.I., Hammes, F., Kötzsch, S., van Loosdrecht, M.C.M., Vrouwenvelder, J.S., 2016a. A systematic approach for the assessment of bacterial growth-controlling factors linked to biological stability of drinking water in distribution systems. Water Science and Technology: Water Supply 16, 865-880.

https://doi.org/10.2166/ws.2016.001

Prest, E.I., Hammes, F., van Loosdrecht, M.C.M., Vrouwenvelder, J.S., 2016b. Biological stability of drinking water: Controlling factors, methods, and challenges. Frontiers in Microbiology 7, 45. https://doi.org/10.3389/fmicb.2016.00045

Proctor, C.R., Besmer, M.D., Langenegger, T., Beck, K., Walser, J.-C., Ackermann, M., Bürgmann, H., Hammes, F., 2018. Phylogenetic clustering of small low nucleic acid-content bacteria across diverse freshwater ecosystems. The Isme Journal 12, 1344-1359. https://doi.org/10.1038/s41396-018-0070-8

Props, R., Kerckhof, F.-M., Rubbens, P., De Vrieze, J., Hernandez Sanabria, E., Waegeman, W., Monsieurs, P., Hammes, F., Boon, N., 2017. Absolute quantification of microbial taxon abundances. The Isme Journal 11, 584-587. https://doi.org/10.1038/ismej.2016.117 
References

Prosser, J.I., Head, I.M., Stein, L.Y., 2014. The Family Nitrosomonadaceae. pp. 901-918 in: Rosenberg, E., DeLong, E.F., Lory, S., Stackebrandt, E., Thompson, F. (Eds), The Prokaryotes: Alphaproteobacteria and Betaproteobacteria, Springer, Berlin, Heidelberg.

Pype, M.-L., Lawrence, M.G., Keller, J., Gernjak, W., 2016. Reverse osmosis integrity monitoring in water reuse: The challenge to verify virus removal - A review. Water Research 98, 384-395. https://doi.org/10.1016/j.watres.2016.04.040

$\mathbf{R}$

Regan, S., Hynds, P., Flynn, R., 2017. An overview of dissolved organic carbon in groundwater and implications for drinking water safety. Hydrogeology Journal 25, 959-967. https://doi.org/10.1007/s10040-017-1583-3

Rittmann, B.E., Huck, P.M., Bouwer, E.J., 1989. Biological treatment of public water supplies. Critical Reviews in Environmental Control 19, 119-184. https://doi.org/10.1080/10643388909388362

Rivas-Marín, E., Devos, D.P., 2018. The paradigms they are a-Changin': Past, present and future of PVC bacteria research. Antonie van Leeuwenhoek 111, 785-799. https://doi.org/10.1007/s10482-017-0962-z

Rook, J., 1974. Formation of haloforms during chlorination of natural waters. Water Treatment and Examination 23, 234-243.

Ross, P.S., Hammes, F., Dignum, M., Magic-Knezev, A., Hambsch, B., Rietveld, L.C., 2013. A comparative study of three different assimilable organic carbon (AOC) methods: Results of a round-robin test. Water Science and Technology: Water Supply 13, 1024-1033. https://doi.org/10.2166/ws.2013.079

Ruggieri, F., Fernandez-Turiel, J.L., Gimeno, D., Valero, F., García, J.C., Medina, M.E., 2008. Limestone selection criteria for EDR water remineralization. Desalination 227, 314-326. http://dx.doi.org/10.1016/j.desal.2007.07.020

Russell, J.B., Wilson, D.B., 1996. Why are ruminal cellulolytic bacteria unable to digest cellulose at low pH? Journal of Dairy Science 79, 1503-1509. https://doi.org/10.3168/jds.S0022-0302(96)76510-4

$\mathbf{S}$

Sack, E.L.W., van der Wielen, P.W.J.J., van der Kooij, D., 2010. Utilization of oligo- and polysaccharides at microgram-per-litre levels in freshwater by Flavobacterium johnsoniae. Journal of Applied Microbiology 108, 1430-1440. https://doi.org/10.1111/j.1365-2672.2009.04546.x

Sack, E.L.W., van der Wielen, P.W.J.J., van der Kooij, D., 2011. Flavobacterium johnsoniae as a model organism for characterizing biopolymer utilization in oligotrophic freshwater environments. Applied and Environmental Microbiology 77, 6931-6938. https://doi.org/10.1128/AEM.00372-11

Sack, E.L.W., van der Wielen, P.W.J.J., van der Kooij, D., 2014. Polysaccharides and proteins added to flowing drinking water at microgram-per-liter levels promote the formation of biofilms predominated by Bacteroidetes and Proteobacteria. Applied and Environmental Microbiology 80, 2360-2371.

https://doi.org/10.1128/AEM.04105-13 
Sadiq, R., Rodriguez, M.J., 2004. Disinfection by-products (DBPs) in drinking water and predictive models for their occurrence: A review. Science of The Total Environment 321, 21-46. https://doi.org/10.1016/j.scitotenv.2003.05.001

Schmidt, B., Sánchez, L.A., Fretschner, T., Kreps, G., Ferrero, M.A., Siñeriz, F., Szewzyk, U., 2014. Isolation of Sphaerotilus-Leptothrix strains from iron bacteria communities in Tierra del Fuego wetlands. FEMS Microbiology Ecology 90, 454466. https://doi.org/10.1111/1574-6941.12406

Schurer, R., Schippers, J.C., Kennedy, M.D., Cornelissen, E.R., Salinas-Rodriguez, S.G., Hijnen, W.A.M., van der Wal, A., 2019. Enhancing biological stability of disinfectant-free drinking water by reducing high molecular weight organic compounds with ultrafiltration posttreatment. Water Research 164, 114927. https://doi.org/10.1016/j.watres.2019.114927

Servais, P., Billen, G., Bouillot, P., 1994. Biological colonization of granular activated carbon filters in drinking-water treatment. Journal of Environmental Engineering 120, 888-899. https://doi.org/10.1061/(ASCE)0733-9372(1994)120:4(888)

Servais, P., Billen, G., Hascoët, M.C., 1987. Determination of the biodegradable fraction of dissolved organic matter in waters. Water Research 21, 445-450.

https://doi.org/10.1016/0043-1354(87)90192-8

Shi-Hu, S., Min, Y., Nai-Yun, G., Wen-Jie, H., 2008. Molecular weight distribution variation of assimilable organic carbon during ozonation/BAC process. Journal of Water Supply: Research and Technology - AQUA 57, 253-258. https://doi.org/10.2166/aqua.2008.041

Shiba, T., Simidu, U., 1982. Erythrobacter longus gen. nov., sp. nov., an aerobic bacterium which contains bacteriochlorophyll a. International Journal of Systematic Bacteriology 32, 211-217. http://dx.doi.org/10.1099/00207713-32-2-211

Siebel, E., Wang, Y., Egli, T., Hammes, F., 2008. Correlations between total cell concentration, total adenosine tri-phosphate concentration and heterotrophic plate counts during microbial monitoring of drinking water. Drinking Water Engineering and Science 1, 1-6. https://doi.org/10.5194/dwes-1-1-2008

Smeets, P.W.M.H., Medema, G.J., van Dijk, J.C., 2009. The Dutch secret: How to provide safe drinking water without chlorine in the Netherlands. Drinking Water Engineering and Science 2, 1-14. https://doi.org/10.5194/dwes-2-1-2009

Smith, A.G., O'Doherty, J.V., Reilly, P., Ryan, M.T., Bahar, B., Sweeney, T., 2011. The effects of laminarin derived from Laminaria digitata on measurements of gut health: Selected bacterial populations, intestinal fermentation, mucin gene expression and cytokine gene expression in the pig. British Journal of Nutrition 105, 669-677. https://doi.org/10.1017/S0007114510004277

Sousi, M., Liu, G., Salinas-Rodriguez, S.G., Chen, L., Dusseldorp, J., Wessels, P., Schippers, J.C., Kennedy, M.D., van der Meer, W., 2020a. Multi-parametric assessment of biological stability of drinking water produced from groundwater: Reverse osmosis vs. conventional treatment. Water Research 186, 116317. https://doi.org/10.1016/j.watres.2020.116317

Sousi, M., Liu, G., Salinas-Rodriguez, S.G., Knezev, A., Blankert, B., Schippers, J.C., van der Meer, W., Kennedy, M.D., 2018. Further developing the bacterial growth potential method for ultra-pure drinking water produced by remineralization of 
reverse osmosis permeate. Water Research 145, 687-696.

https://doi.org/10.1016/j.watres.2018.09.002

Sousi, M., Salinas-Rodriguez, S.G., Liu, G., Schippers, J.C., Kennedy, M.D., van der Meer, W., 2020b. Measuring bacterial growth potential of ultra-low nutrient drinking water produced by reverse osmosis: Effect of sample pre-treatment and bacterial inoculum. Frontiers in Microbiology 11, 791.

https://doi.org/10.3389/fmicb.2020.00791

Stewart, B.T., Halvorson, H.O., 1953. Studies on the spores of aerobic bacteria. I. The occurrence of alanine racemase. Journal of Bacteriology 65, 160-166.

\section{$\mathbf{T}$}

Takashima, M., Speece, R.E., Parkin, G.F., 1990. Mineral requirements for methane fermentation. Critical Reviews in Environmental Control 19, 465-479. https://doi.org/10.1080/10643389009388378

Thayanukul, P., Kurisu, F., Kasuga, I., Furumai, H., 2013. Evaluation of microbial regrowth potential by assimilable organic carbon in various reclaimed water and distribution systems. Water Research 47, 225-232.

https://doi.org/10.1016/j.watres.2012.09.051

Tran, Q.H., Unden, G., 1998. Changes in the proton potential and the cellular energetics of Escherichia coli during growth by aerobic and anaerobic respiration or by fermentation. European Journal of Biochemistry 251, 538-543. https://doi.org/10.1046/j.1432-1327.1998.2510538.x

Trchounian, A., Ohanjanyan, Y., Bagramyan, K., Vardanian, V., Zakharyan, E., Vassilian, A., Davtian, M., 1998. Relationship of the Escherichia coli TrkA system of potassium ion uptake with the $\mathrm{F}_{0} \mathrm{~F}_{1}$-ATPase under growth conditions without anaerobic or aerobic respiration. Bioscience Reports 18, 143-154.

https://doi.org/10.1023/a:1020144628839

V

van der Bruggen, B., Vandecasteele, C., 2003. Removal of pollutants from surface water and groundwater by nanofiltration: Overview of possible applications in the drinking water industry. Environmental Pollution 122, 435-445. https://doi.org/10.1016/S0269-7491(02)00308-1

van der Kooij, D., 1992. Assimilable organic carbon as an indicator of bacterial regrowth. Journal - American Water Works Association 84, 57-65.

van der Kooij, D., 2000. Biological stability: A multidimensional quality aspect of treated water. Water, Air, and Soil Pollution 123, 25-34. https://doi.org/10.1023/A:1005288720291

van der Kooij, D., Hijnen, W.A.M., 1984. Substrate utilization by an oxalate-consuming Spirillum species in relation to its growth in ozonated water. Applied and Environmental Microbiology 47, 551-559.

van der Kooij, D., Hijnen, W.A.M., Kruithof, J.C., 1989. The effects of ozonation, biological filtration and distribution on the concentration of easily assimilable organic carbon (AOC) in drinking water. The Journal of the International Ozone Association 11, 297-311. https://doi.org/10.1080/01919518908552443 
van der Kooij, D., Veenendaal, H.R., 2001. Biomass production potential of materials in contact with drinking water: Method and practical importance. Water Science and Technology: Water Supply 1, 39-45.

van der Kooij, D., Veenendaal, H.R., 2014. Regrowth problems and biostability assessment in the Netherlands. pp. 291-337 in: van der Kooij, D., van der Wielen, P.W.J.J. (Eds), Microbial growth in drinking-water supplies: Problems, causes, control and research needs, IWA Publishing, London.

van der Kooij, D., Veenendaal, H.R., Dammers, N., 2014. Bepaling van de biomassaproductiepotentie (BPP) van drinkwater. KWR, report, BTO 2014.038, Nieuwegein, the Netherlands.

van der Kooij, D., Veenendaal, H.R., van der Mark, E.J., Dignum, M., 2017. Assessment of the microbial growth potential of slow sand filtrate with the biomass production potential test in comparison with the assimilable organic carbon method. Water Research 125, 270-279. https://doi.org/10.1016/j.watres.2017.06.086

van der Kooij, D., Visser, A., Hijnen, W.A.M., 1982. Determining the concentration of easily assimilable organic carbon in drinking water. Journal - American Water Works Association 74, 540-545. https://doi.org/10.1002/j.15518833.1982.tb05000.x

van der Wielen, P.W.J.J., van der Kooij, D., 2010. Effect of water composition, distance and season on the adenosine triphosphate concentration in unchlorinated drinking water in the Netherlands. Water Research 44, 4860-4867.

https://doi.org/10.1016/j.watres.2010.07.016

van Nevel, S., Koetzsch, S., Proctor, C.R., Besmer, M.D., Prest, E.I., Vrouwenvelder, J.S., Knezev, A., Boon, N., Hammes, F., 2017. Flow cytometric bacterial cell counts challenge conventional heterotrophic plate counts for routine microbiological drinking water monitoring. Water Research 113, 191-206. https://doi.org/10.1016/j.watres.2017.01.065

Velten, S., Boller, M., Köster, O., Helbing, J., Weilenmann, H.-U., Hammes, F., 2011. Development of biomass in a drinking water granular active carbon (GAC) filter. Water Research 45, 6347-6354. https://doi.org/10.1016/j.watres.2011.09.017

Vewin, 2017. Dutch drinking water statistics 2017: From source to tap. Association of Dutch water companies (Vewin), Rijswijk, the Netherlands.

Villacorte, L.O., Tabatabai, S.A.A., Dhakal, N., Amy, G., Schippers, J.C., Kennedy, M.D., 2015. Algal blooms: An emerging threat to seawater reverse osmosis desalination. Desalination and Water Treatment 55, 2601-2611. https://doi.org/10.1080/19443994.2014.940649

Vingerhoeds, M.H., Nijenhuis-de Vries, M.A., Ruepert, N., van der Laan, H., Bredie, W.L.P., Kremer, S., 2016. Sensory quality of drinking water produced by reverse osmosis membrane filtration followed by remineralisation. Water Research 94, 4251. https://doi.org/10.1016/j.watres.2016.02.043

Vital, M., Dignum, M., Magic-Knezev, A., Ross, P., Rietveld, L., Hammes, F., 2012. Flow cytometry and adenosine tri-phosphate analysis: Alternative possibilities to evaluate major bacteriological changes in drinking water treatment and distribution systems. Water Research 46, 4665-4676. https://doi.org/10.1016/j.watres.2012.06.010 
Vital, M., Füchslin, H.P., Hammes, F., Egli, T., 2007. Growth of Vibrio cholerae O1 Ogawa Eltor in freshwater. Microbiology 153, 1993-2001. https://doi.org/10.1099/mic.0.2006/005173-0

Vital, M., Stucki, D., Egli, T., Hammes, F., 2010. Evaluating the growth potential of pathogenic bacteria in water. Applied and Environmental Microbiology 76, 64776484. https://doi.org/10.1128/AEM.00794-10

Volk, C.J., LeChevallier, M.W., 1999. Impacts of the reduction of nutrient levels on bacterial water quality in distribution systems. Applied and Environmental Microbiology 65, 4957-4966.

Vree, J., 2007. God van vooruitgang. De popularisering van het modern-theologische gedachtegoed in Nederland (1857-1880). Church History and Religious Culture 87, 581-583. https://doi.org/10.1163/187124107X258635

Vroman, I., Tighzert, L., 2009. Biodegradable polymers. Materials 2, 307-344. https://doi.org/10.3390/ma2020307

W

Wang, Q., Tao, T., Xin, K., 2014. The relationship between water biostability and initial bacterial growth variations to different organic carbon concentrations. Procedia Engineering 89, 160-167. https://doi.org/10.1016/j.proeng.2014.11.172

Wang, Y., Hammes, F., Boon, N., Chami, M., Egli, T., 2009. Isolation and characterization of low nucleic acid (LNA)-content bacteria. The Isme Journal 3, 889-902. https://doi.org/10.1038/ismej.2009.46

Webster, J.J., Hampton, G.J., Wilson, J.T., Ghiorse, W.C., Leach, F.R., 1985. Determination of microbial cell numbers in subsurface samples. Groundwater 23, 17-25. https://doi.org/10.1111/j.1745-6584.1985.tb02775.x

Weinrich, L.A., Giraldo, E., LeChevallier, M.W., 2009. Development and application of a bioluminescence-based test for assimilable organic carbon in reclaimed waters. Applied and Environmental Microbiology 75, 7385-7390. https://doi.org/10.1128/AEM.01728-09

Whaley, D.N., Dowell, V.R., Wanderlinder, L.M., Lombard, G.L., 1982. Gelatin agar medium for detecting gelatinase production by anaerobic bacteria. Journal of Clinical Microbiology 16, 224-229.

Williams, K., Pruden, A., Falkinham, J.O., Edwards, M., 2015. Relationship between organic carbon and opportunistic pathogens in simulated glass water heaters. Pathogens 4, 355-372. https://doi.org/10.3390/pathogens4020355

Withers, N., Drikas, M., 1998. Bacterial regrowth potential: Quantitative measure by acetate carbon equivalents. Water 25, 19-23. 


\section{LIST OF ABBREVIATIONS}

\begin{tabular}{|c|c|}
\hline $\mathrm{ACF}$ & Activated carbon filtrate \\
\hline AGW & Anaerobic groundwater \\
\hline ANOVA & One-way analysis of variance \\
\hline AOB & Ammonium-oxidising bacteria \\
\hline AOC & Assimilable organic carbon \\
\hline ATP & Adenosine triphosphate \\
\hline BDOC & Biodegradable dissolved organic carbon \\
\hline BEW & Bottled Evian water \\
\hline BFP & Biofilm formation potential \\
\hline BGP & Bacterial growth potential \\
\hline BGP $_{\text {ATP }}$ & Bacterial growth potential based on adenosine triphosphate \\
\hline BGP ICC $_{\text {IC }}$ & Bacterial growth potential based on intact cell count \\
\hline BGP $_{\max }$ & Maximum bacterial growth potential \\
\hline BGP $_{\text {net }}$ & Net bacterial growth potential \\
\hline $\mathbf{C C}$ & Calcite contactors \\
\hline CCA & Canonical correspondence analysis \\
\hline CTW & Conventionally treated drinking water \\
\hline DBPs & Disinfection by-products \\
\hline DGW & Deep groundwater \\
\hline DOC & Dissolved organic carbon \\
\hline DSF & Dry sand filtration \\
\hline FCM & Flow cytometry \\
\hline GAC & Granular activated carbon \\
\hline HMW & High molecular weight polymers \\
\hline HNA & High nucleic acid bacterial cells \\
\hline HPC & Heterotrophic plate count \\
\hline ICC & Intact cell count \\
\hline IEX & Ion exchange \\
\hline lab-Remin & laboratory-remineralised $\mathrm{RO}$ permeate \\
\hline LC-OCD & Liquid chromatography-organic carbon detection \\
\hline LMW & Low molecular weight polymers \\
\hline LNA & Low nucleic acid bacterial cells \\
\hline MAP & Microbially available phosphate \\
\hline
\end{tabular}


LIst of abbreviations

MOB Methane-oxidising bacteria

NOB Nitrite-oxidising bacteria

OTUs Operational taxonomic units

PCoA Principal coordinates analysis

PERMANOVA Permutational multivariate analysis of variance

RLU Relative light units

RO Reverse osmosis

RSF Rapid sand filtration

site-Remin Site-remineralised RO permeate

SOF softening

SSF Slow sand filtrate

TCC Total cell count

UVD UV disinfection

$\mathbf{Y}_{\text {ATP }} \quad$ Bacterial yield based on adenosine triphosphate

Y ICC Bacterial yield based on intact cell count 


\section{ABOUT THE AUTHOR}

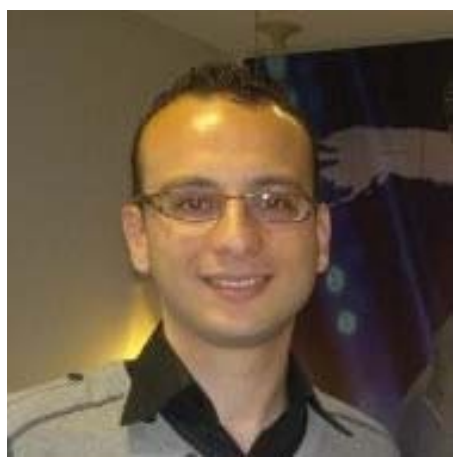

Mohaned Sousi was born on the $30^{\text {th }}$ of August 1987 in Gaza, Palestine. In 2005, he started his Bachelor's study in Civil Engineering at the University of Gaza, where he served as a teaching assistant for one year and a half after completing his study in 2010. In 2013, Mohaned obtained his Master's degree with distinction in Water Supply Engineering at IHE-Delft Institute for Water Education, the Netherlands. His Master's thesis focused on investigating a new strategy to control biofouling in reverse osmosis systems using low molecular weight cut-off ultrafiltration membranes. After graduating, he worked at IHEDelft as a researcher before starting his PhD study in the Environmental Engineering and Water Technology Department in November 2014. His PhD research focused on assessing biological stability of drinking water produced by reverse osmosis and remineralisation. Mohaned's research has been conducted under the joint supervision of IHE-Delft and the University of Twente. In addition, Mohaned conducted his research in close collaboration with Oasen Drinking Water Company, which sponsored his research. During his $\mathrm{PhD}$ journey, Mohaned worked with different water entities including Evides Drinking Water Company, Delft University of Technology and Het Waterlaboratorium. 
About the author

\section{List of publications and contributions}

Peer-reviewed publications

Sousi, M., Liu, G., Salinas-Rodriguez, S.G., Knezev, A., Blankert, B., Schippers, J.C., van der Meer, W., Kennedy, M.D., 2018. Further developing the bacterial growth potential method for ultra-pure drinking water produced by remineralisation of reverse osmosis permeate. Water Research 145, 687-696.

https://doi.org/10.1016/j.watres.2018.09.002

Sousi, M., Salinas-Rodriguez, S.G., Liu, G., Schippers, J.C., Kennedy, M.D., van der Meer, W., 2020. Measuring bacterial growth potential of ultra-low nutrient drinking water produced by reverse osmosis: Effect of sample pre-treatment and bacterial inoculum. Frontiers in Microbiology 11, 791.

https://doi.org/10.3389/fmicb.2020.00791

Sousi, M., Liu, G., Salinas-Rodriguez, S.G., Chen, L., Dusseldorp, J., Wessels, P., Schippers, J.C., Kennedy, M.D., van der Meer, W., 2020. Multi-parametric assessment of biological stability of drinking water produced from groundwater: Reverse osmosis vs. conventional treatment. Water Research 186, 116317. https://doi.org/10.1016/j.watres.2020.116317

Sousi, M., Salinas-Rodriguez, S.G., Liu, G., Dusseldorp, J., Kemperman, A.J.B., Schippers, J.C., van der Meer, W.G.J., Kennedy, M.D., 2021. Comparing the bacterial growth potential of ultra-low nutrient drinking water assessed by growth tests based on flow cytometric intact cell count versus adenosine triphosphate. Water Research 203, 117506. https://doi.org/10.1016/j.watres.2021.117506

\section{Contribution to publications}

Schurer, R., Schippers, J.C., Kennedy, M.D., Cornelissen, E.R., Salinas-Rodriguez, S.G., Hijnen, W.A.M., van der Wal, A., 2019. Enhancing biological stability of disinfectant-free drinking water by reducing high molecular weight organic compounds with ultrafiltration posttreatment. Water Research 164, 114927. https://doi.org/10.1016/j.watres.2019.114927 
About the author

Oral and poster presentations at (international) conferences

IHE-Delft PhD Symposium: Delft, the Netherlands, 28-29 September, 2015.

Poster presentation: Impact of reverse osmosis and remineralisation on the biological stability of drinking water

International Water Week Amsterdam (AIWW): Amsterdam, the Netherlands, 2-6

November, 2015.

Contributing to oral presentation: Search for the best remineralisation technology

European Desalination Society (EDS) international conference: Desalination for the

Environment: Clean Water and Energy, Rome, Italy, 22-26 May, 2016.

Oral presentation: Assessing the improvement in biological stability of drinking

water after reverse osmosis and remineralisation

IHE-Delft PhD Symposium: From Water Scarcity to Water Security, Delft, the

Netherlands, 3-4 October, 2016.

Oral presentation: Impact of reverse osmosis and remineralisation on the biological

stability of drinking water (best presentation award)

European Desalination Society (EDS) international conference: Desalination for the

Environment: Clean Water and Energy, Athens, Greece, 3-6 September, 2018.

Oral presentation: Assessing the improvement in biological stability of drinking

water after reverse osmosis and remineralisation (moderator of the session) 


\title{
SENSE
}

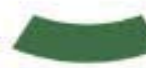

Netherlands Research School for the

Socio-Economic and Natural Sciences of the Environment

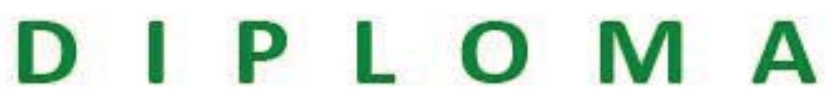

For specialised PhD training

The Netherlands Research School for the

Socio-Economic and Natural Sciences of the Environment

(SENSE) declares that

\section{Mohaned Sousi}

\author{
born on 30 August 1987 in Gaza, Palestine
}

has successfully fulfilled all requirements of the

Educational Programme of SENSE.

Enschede, 9 December 2021

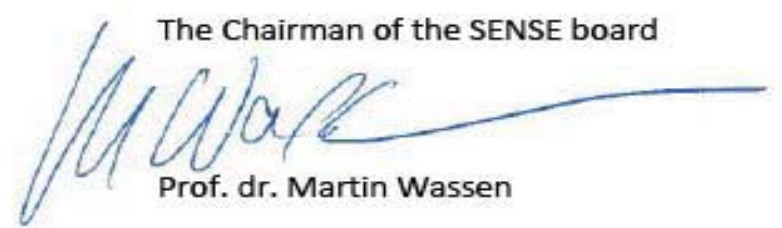

the SENSE Director of Education

The SENSE Research School has been accredited by the Royal Netherlands Academy of Arts and Sciences (KNAW)

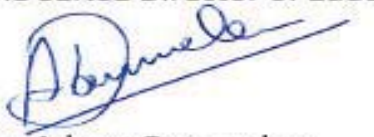

Dr. Ad van Dommelen

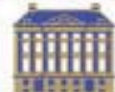

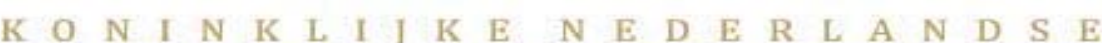

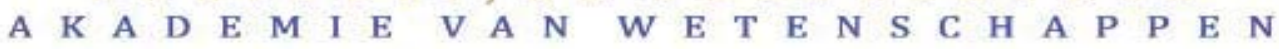




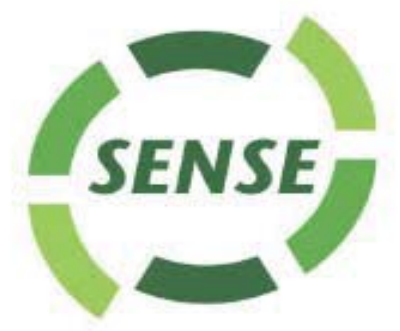

The SENSE Research School declares that Mohaned Sousi has successfully fulfilled all requirements of the Educational PhD Programme of SENSE with a work load of $33.4 \mathrm{EC}$, including the following activities:

\section{SENSE PhD Courses}

- Environmental research in context (2015)

- Research in context activity: 'Preparing and co-organizing Annual PhD Symposium of IHE Delft, Institute for Water Education (Delft, 2-3 October 2017)'

- Speciation and Bioavailability of Metals, Organics and Nanoparticles, organised by University of Antwerp and SENSE (2017)

\section{Other PhD and Advanced MSc Courses}

- Basic statistics, Wageningen University (2017)

- English Writing course, IHE Delft (2018)

\section{Management and Didactic Skills Training}

- Supervising three MSc students with theses (2015-2017)

Supervising two BSc students with theses (2017-2019)

- Assisting in laboratory sessions of the MSc course 'Advanced water treatment' (20152019)

- Member of the PhD fellow's Association Board (PAB) of IHE Delft (2016-2018)

\section{Oral Presentations}

- Assessing the improvement in biological stability of drinking water after reverse osmosis and remineralization. Desalination for the Environment: Clean Water and Energy European Desalination Society, 3-6 September 2018, Athens, Greece

- Assessing the improvement in biological stability of drinking water after reverse osmosis and remineralization. Desalination for the Environment: Clean Water and Energy European Desalination Society, 22-26 May 2016, Rome, Italy

- Assessing the improvement in biological stability of drinking water after reverse osmosis and remineralization. IHE Delft PhD Symposium:: From Water Scarcity to Water Security, 3-4 October 2016, Delft, the Netherlands

\section{SENSE Coordinator PhD Education}

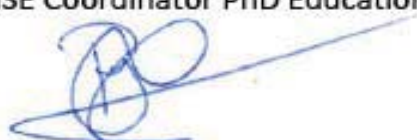

Dr. ir. Peter Vermeulen 
The aim of this thesis was to compare reverse osmosis and remineralisation with conventional treatment in terms of the Bacterial Growth Potential (BGP) of drinking water. However, existing BGP methods were unsuitable as the detection level was too high to measure ultra-low nutrient water produced by RO. Hence, the focus of this thesis was to: (i) further develop the method to reliably measure the BGP of RO permeate, (ii) apply the improved BGP method to compare RO and conventional treatment.

Several improvements were made to the BGP method, resulting in $>2.5$-fold reduction in its detection limit, due to using an ultra-pure blank prepared from laboratory-remineralised RO permeate. Applying the improved method showed that the BGP of drinking water was reduced by $>75 \%$ after $\mathrm{RO}$ compared with conventional treatment as $>99 \%$ nutrient removal (carbon and phosphate) was achieved with RO. Moreover, remineralisation adversely affected RO permeate quality, and measures are recommended to mitigate the impact of post-treatment on BGP.

The improved BGP method can be used to reliably monitor BGP of ultra-low nutrient water. This development opens up new avenues of research towards improved analytical techniques to identify compounds utilised by bacteria for growth and how to remove these during treatment as well as understanding the effect of ultra-low nutrient water on bacterial growth and ecology in distribution systems. 